\title{
THE PANAMA GUIDE
}

JOHN O. COLLINS

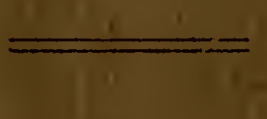

PUBLISHED FOR

I. L. MADURO, Jr., PANAMA 


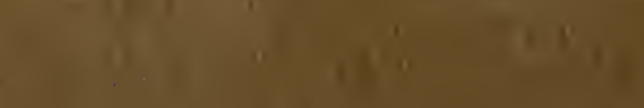




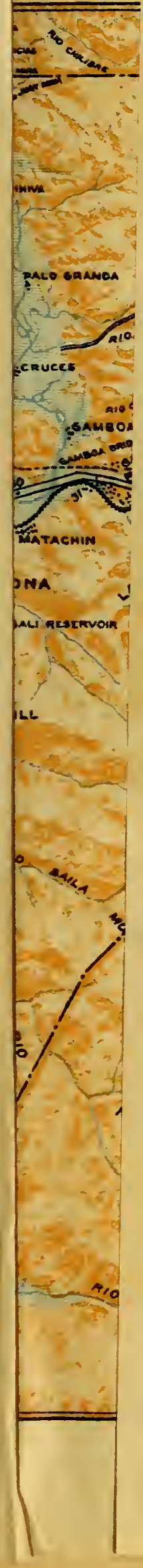





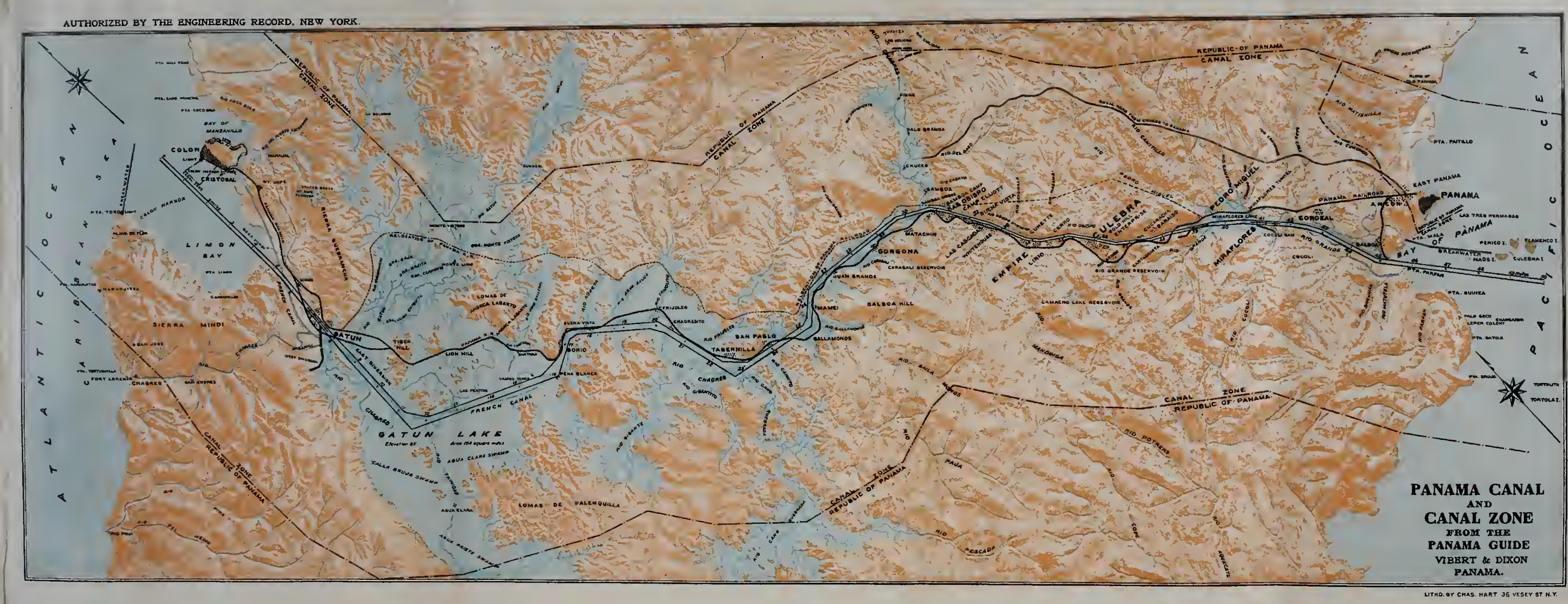




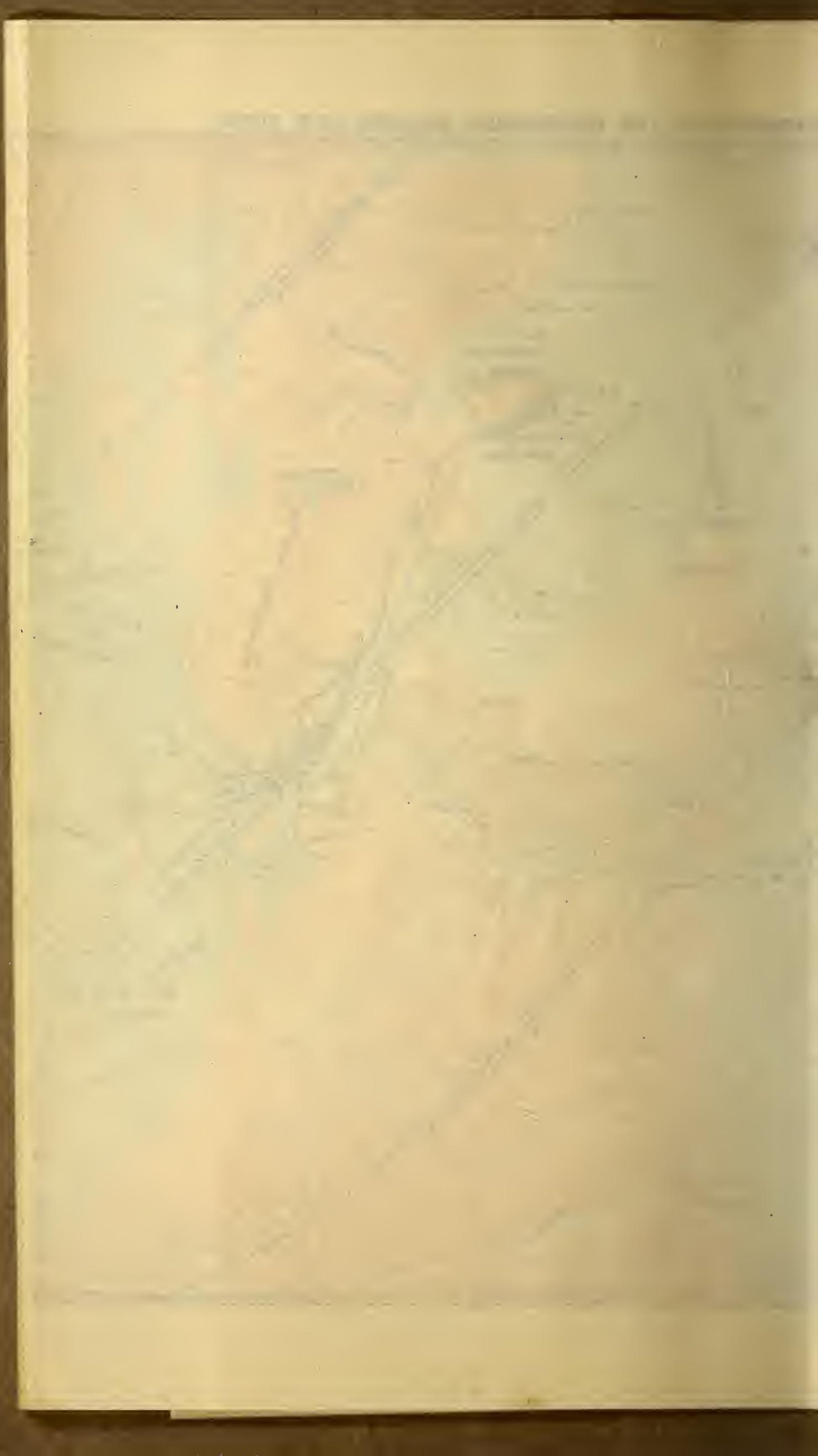




\section{F \\ 1564 \\ C71 \\ 1912 THE PANAMA GUIDE STRI}

Copyright, 1912

JOHN O. COI.IINS
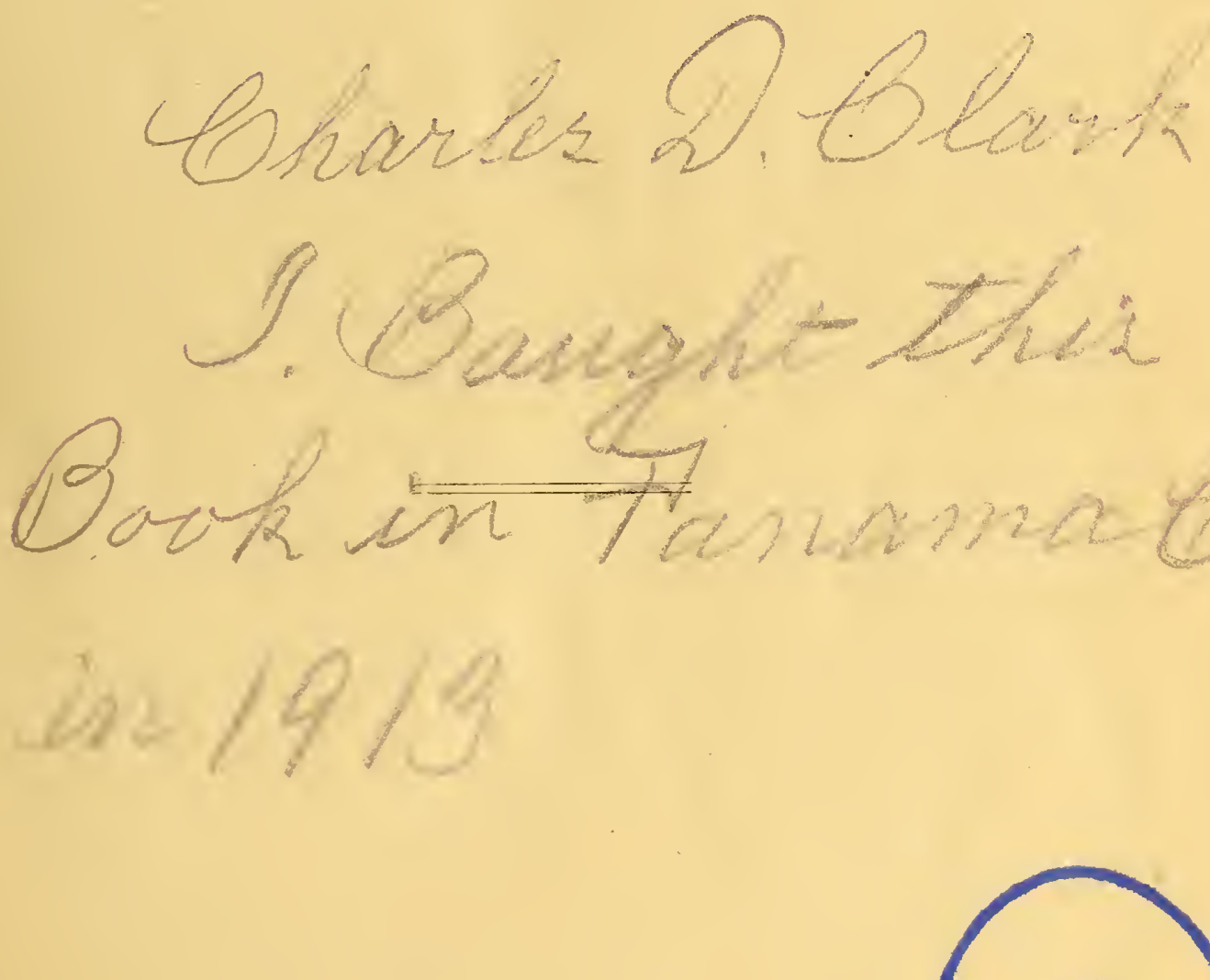

I. C. C. Press

Quartermaster's Department

Mount Hope, C. $Z$.

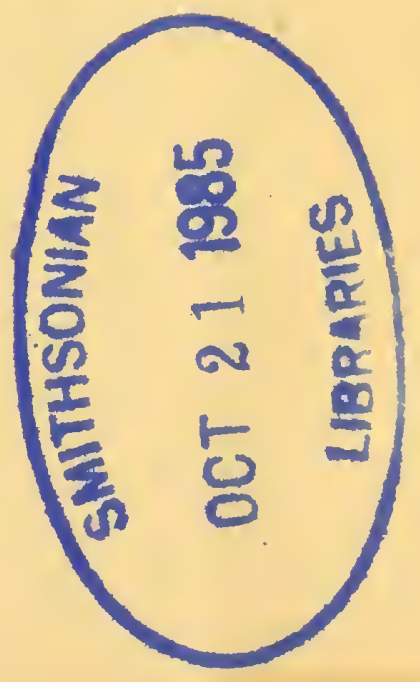




\section{INTRODUCTION}

This Guide Book answers most of the questions that I have been asked during the past four years regarding Panama and the Panama Canal. It is a compilation from reliable sources. Only a few of the many books on the Panama Canal are reliable, and in my text I have quoted only these: "Panama" by Albert Edwards, "Panama" in Porter's Progress of the Nations Series, "Old Panama" by Dr. C.L.G. Anderson, the Panama Government's school history by Sosa and Arce, the annual reports of the Isthmian Canal Commission, and "The Canal Record" are especially commended to those who wish a deeper knowledge of Panama and the Canal than this guide book can give.

Ancon. 1912.

JOHN O. COLLINS. 


\section{Contents.}

Introduction

Contents'...

Illustrations

Advertisers

The Master Builder...

From Colon to Panama:

Cristobal-Colon

Gatun.

Lake Villages

Relocation Country

Culebra Cut Villages

From "The Cut" to the Sea

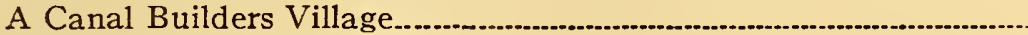

Social Conditions and Forces

The Panama Canal:

History.

French Attempt

American Canal

Sanitation and Health

Labor Force, Housing.

Canal Zone.

Administration.

Sea Level Plan.

Lake Level Plan.

Sea Level Channels.

The Locks.

Dams

Gatun and Miraflores Lakes

Culebra Cut

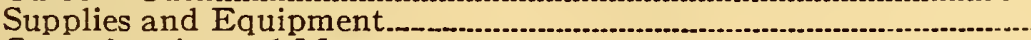

Commissaries and Messes

Terminal, Repair, Supply Facilities

The Cost.

Distances by way of Canal.

Fortification and Neutralization

Panama Railroad

Conquest and Settlement

Period of the Great Trade

Privateers, Pirates.

Decadence to Renascence

Panama To-Day.

People and Institutions.--.-.-.-

Resources

Pearl Islands and Fisheries

Cocos.Island Treasure

Taboga Island.

City of Panama..

Churches.

Old Panama

Porto Bello

Fort San Lorenzo

Nombre de Dios

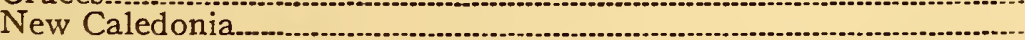

Old Darien

Miscellaneous:

Things Not True

Trees and Plants.

Weather and Meteorology

Latitude and Longitude.

Postage Rates

Customs Regulations.

The Stars

Regulations

Treaties

Acts of Congress on Panama Canal

Canal Zone Census 


\section{Illustrations}

Index.

Map of Canal Zone

Goethals

Isthmian Canal Commission

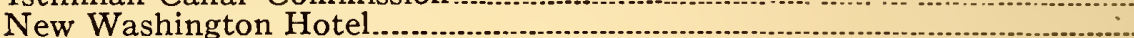

Christ Church, Colon

Plaza, Colon

Sea Front, Cristobal

Map of Cristobal-Colon

Gatun Locks.

Chagres River Scene.

Steamshovel-Culebra Cut

Locks at Pedro Miguel.

Street in Canal Village.

Ancon Hospital Grounds.

Hotel Tivoli

Commission Clubhouse

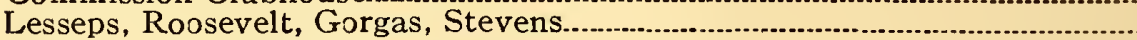

Map of Canal Routes.

Atlantic Entrance and Gatun

Pacific Entrance to Culebra Cut...........

Cross Section of Locks.

Position of Lock Gates

Gatun Locks.

Pedro Miguel Locks and Dam

Gatun Dam

Gatun Spillway

Section of Spillway Dams

Culebra Cut at Summit

Map of Panama Republic

Presidents of Panama

Panama City in 1857, Map

Church of Santa Ana

Church of La Merced

Cathedral

Sea Wall

Beach Market

Flat Arch Church

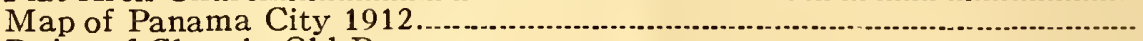

Ruins of Church, Old Panama.

Old Panama in 1609, Map

Castle San Jerome, Porto Bello

Street in Native Village.

Star Charts

Canal Medal

International Hotel, Panama

Steamship Avon

Cable used Gatun Handling Plant

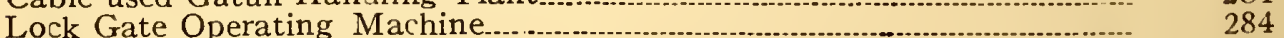

Dump Car, Panama type

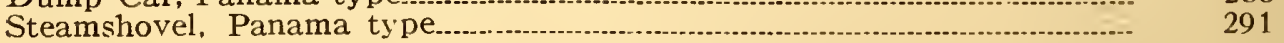

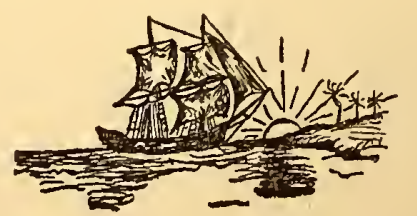




\section{List of Advertisers.}

Announcement, Panama Guide

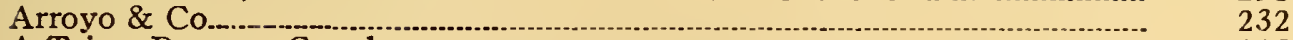

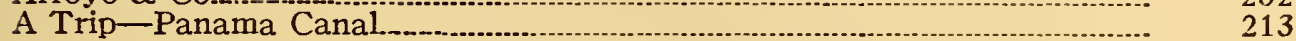

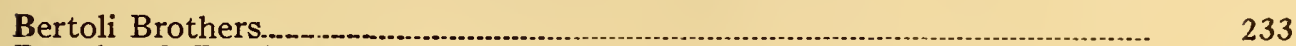

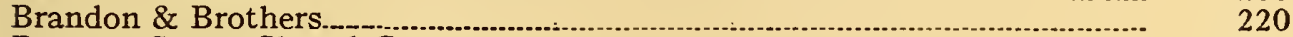

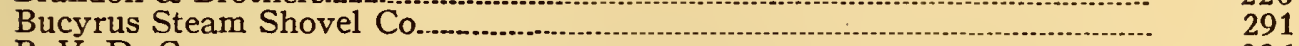

B. V. D. Co._.

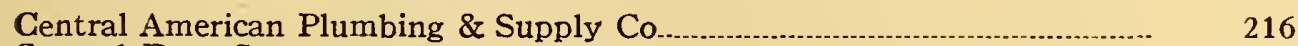

Central Drug Store............... 212

Central Hotel

Colgate \& Co

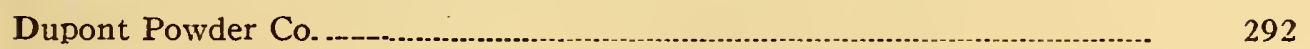

Ehrman \& Co. .

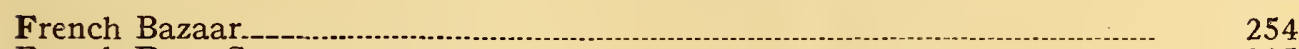

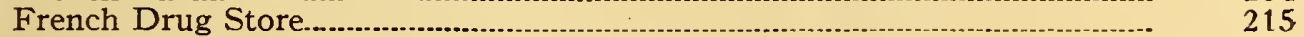

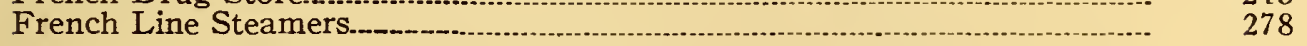

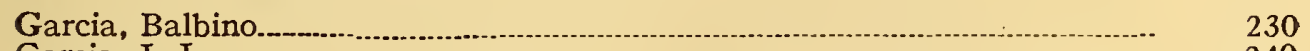

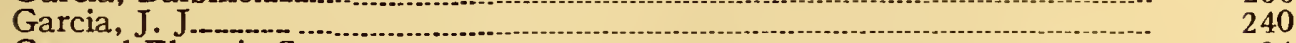

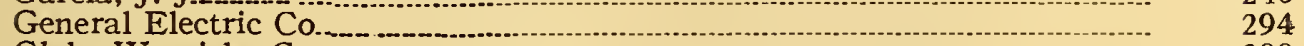

Globe-Wernicke Co._.

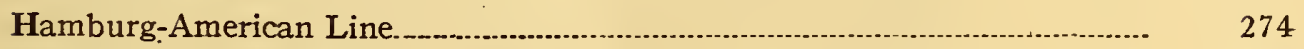

Illinois Centra! Railroad............................................................................. 282

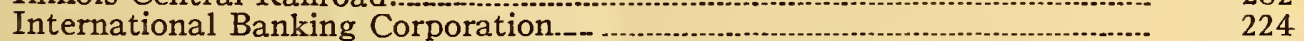

International Correspondence Schools

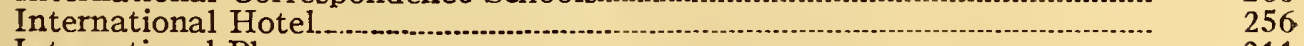

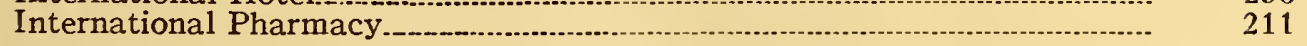

Kerr, J. L.

Keystone National Powder Co-....- 290

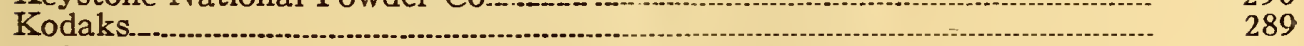

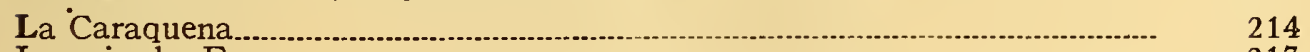

Lacroisade, E

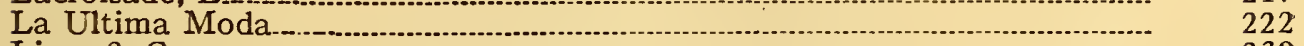

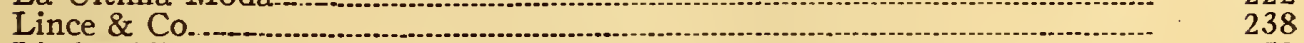

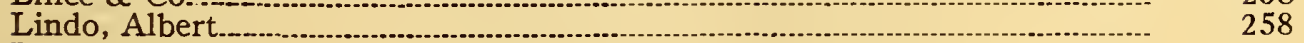

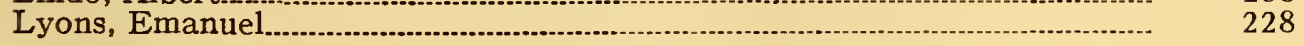

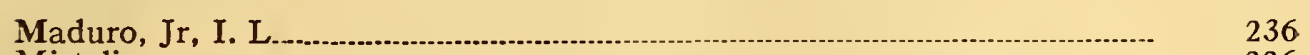

Misteli..._.

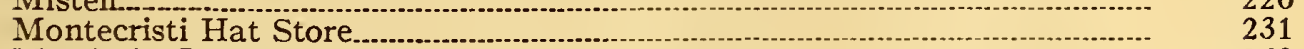

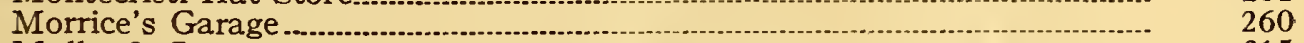

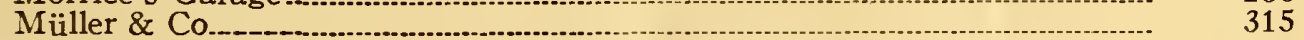

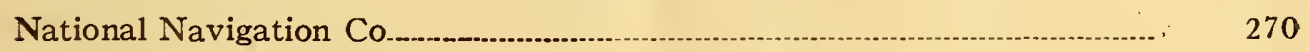

Pacific Steam Navigation Co..................... 276

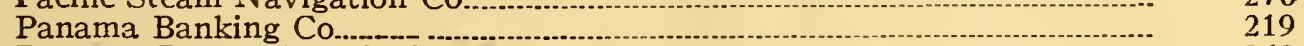

Panama Gem and Curio Co

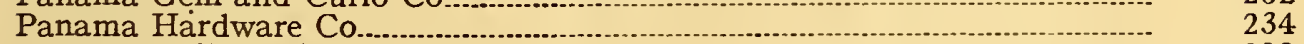

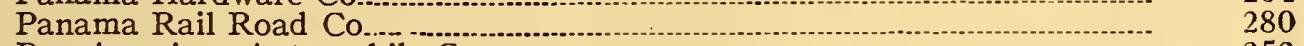

Pan-American Automobile Co._-

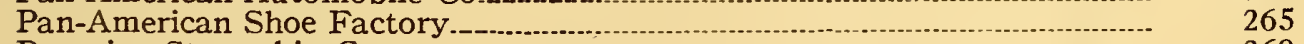

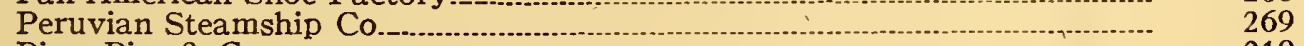

Piza, Piza \& Co._.

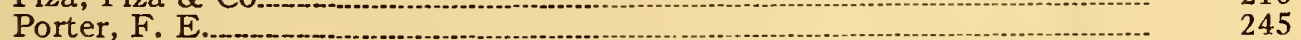

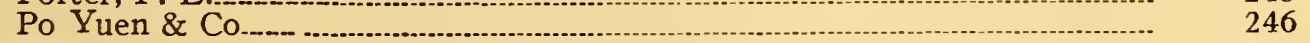

Richards, H. Alex

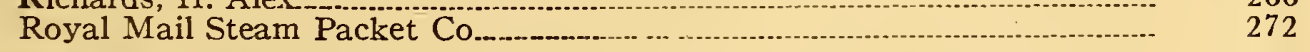

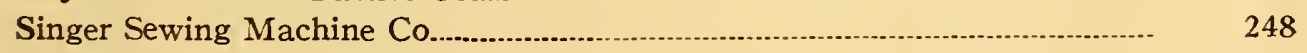

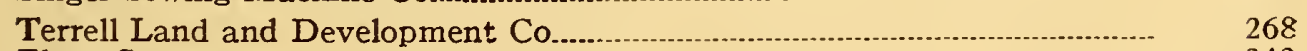

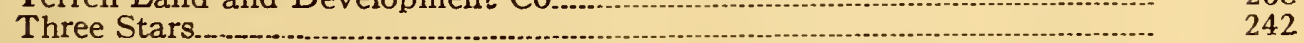

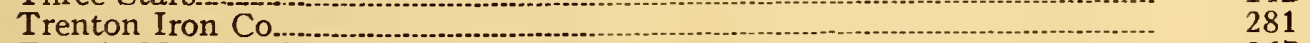

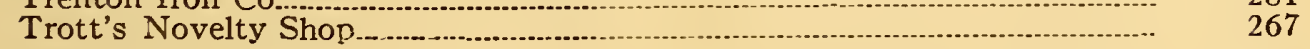

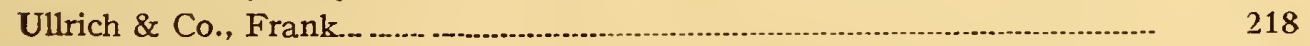

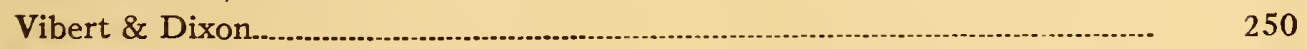

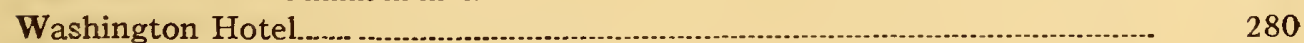

Waterman (L. E.) Ideal Fountain Pen

Western Wheeled Scraper Co

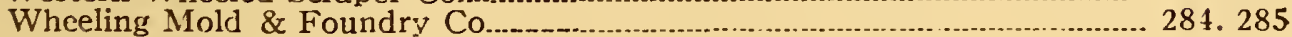




\section{The Master Builder.}

Everywhere one goes on the Isthmus he will hear: "The Colonel said," and "The Colonel did," and many other references to "The Colonel." "The Colonel" is Geo. W. Goethals, Chairman of the Isthmian Canal Commission, Chief Engineer of the Canal, President of the Panama irailroad; Governor of the Canal Zone, resident member of the Panama Canal Fortification Board in charge of construction, and, combining all these officials in one, he is the autocrat of the Canal Zone.

No one is more careful than Colonel Goethals to give due credit to his predecessors and coworkers for their share in the success of the Panama Canal. It is not an invidious comparison, therefore, to say that no one so much as he personifies that success.

A virtual despot over a little kingdom of 50,000 workers, he shows every day the decision, resourcefulness, and tact that mark a great executive. Some of his coworkers disagree with him in questions of policy, but they all pay tribute to his ability. With the mass of the workers he commands the respect that only able and honest men can win, and such sympathy as is accorded only to very human men.

He is six feet tall, every inch bone and muscle. No one on the force works harder than he. His day begins ordinarily at 7 o'clock in the morning when he takes one of the early trains from Culebra for his tour of inspection. The afternoon is spent in his office at Culebra, and of ten he works there until his bedtime, 10 o'clock.

On Sunday mornings he holds court at Culebra to hear the complain ts or petitions of the workers under him. There is no labore: that cannot get an audience with the despot, no tale so petty that it cannot find in him a patient listener. The knowledge that this is true has a restraining influence on men who might take advantage of petty authority, inspires every worker with confidence, and promotes general satisfaction.

Colonel Goethals' administration began in April, 1907, and since then there have been disbursed under his direction about two hundred and twenty million dollars, without one suspicion of favoritism or of the aggrandizement of himself or any. of his subordinates. His record of wise, honest service is quite unique.

Now that his fame is secure, many men are flattering him, great universities have conferred degrees upon him, and many who have watched his work in Panama hope that his country may one day have his services as its President. But no tribute that may fall to him will be counted so great as this-

The men who have worked with and under

him believe him Able, Wise, and Just.

Geo. W. Goethals (Colonel, Corps of Engineers, U. S. A.). Born Brooklyn, June 28, 1858. College of the City of New York. Cadet Military Academy, June 14, 1876, second lieutenant Corps of Engineers, June 12, 1880 ; first lieutenant, June 15, 1882; captain, December 14, 1891; major, February 7, 1900; lieutenant-colonel, March 2, 1907; colonel, December 3,1909 ; lieutenant-colonel volunteer service and a chief of engineers, May 26, 1898, to December 31, 1898; General Staff, August 15, 1903, to March 4, 1907; graduate Army War College, 1905. For several years instructor in Civil and Military Engineering at West Point; in charge of construction Mussel Shoals (Tennessee River) canal; member of Board of Coast and Harbor Defense. Chairman of the Isthmian Canal Commission, and Chief Engineer of Panama Canal since April 1, 1907. Governor of Cana Zone; President of Panama Railroad; Member of Panama Canal Fortification Board in charge of construction. 


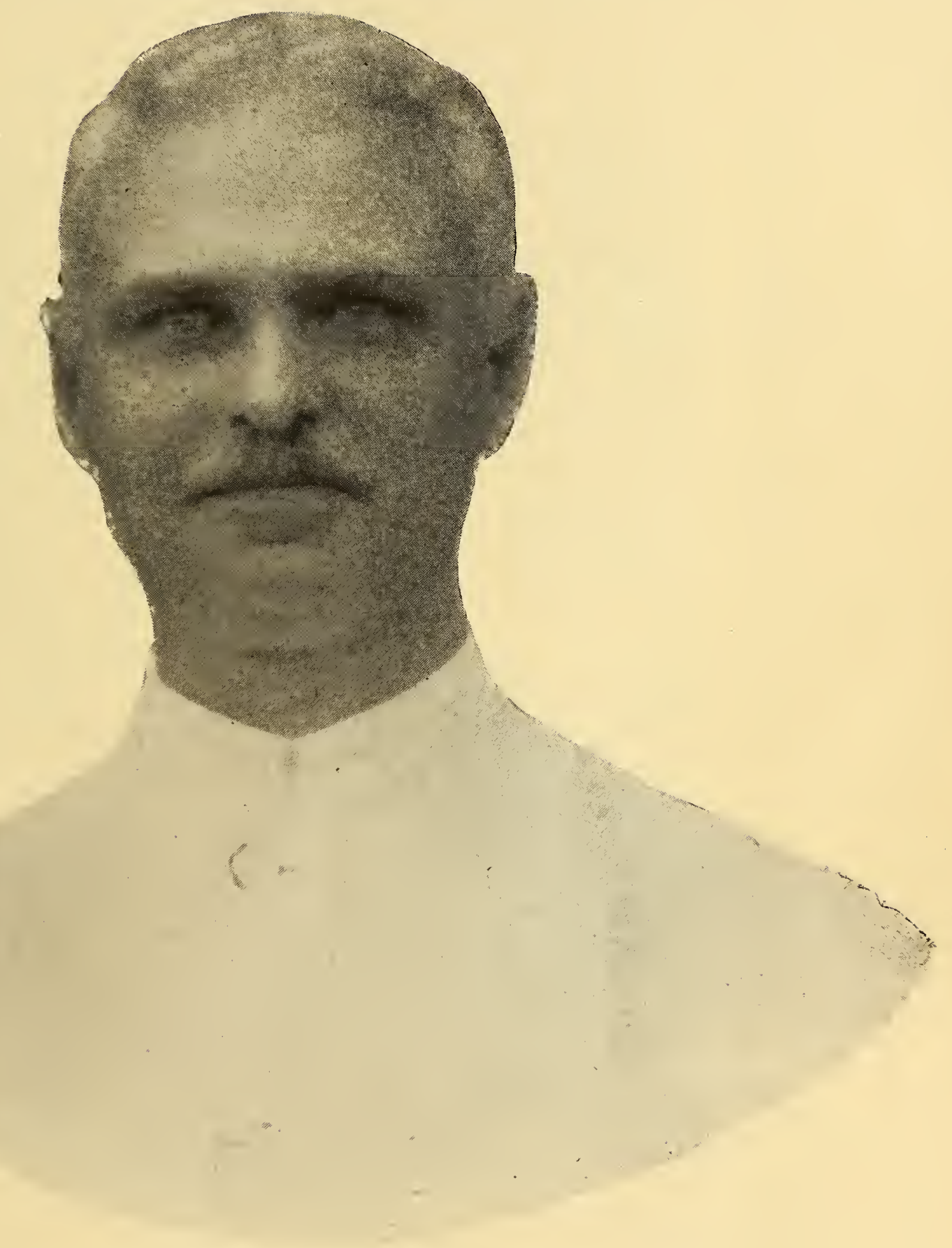

GEO. W. GOETHALS 


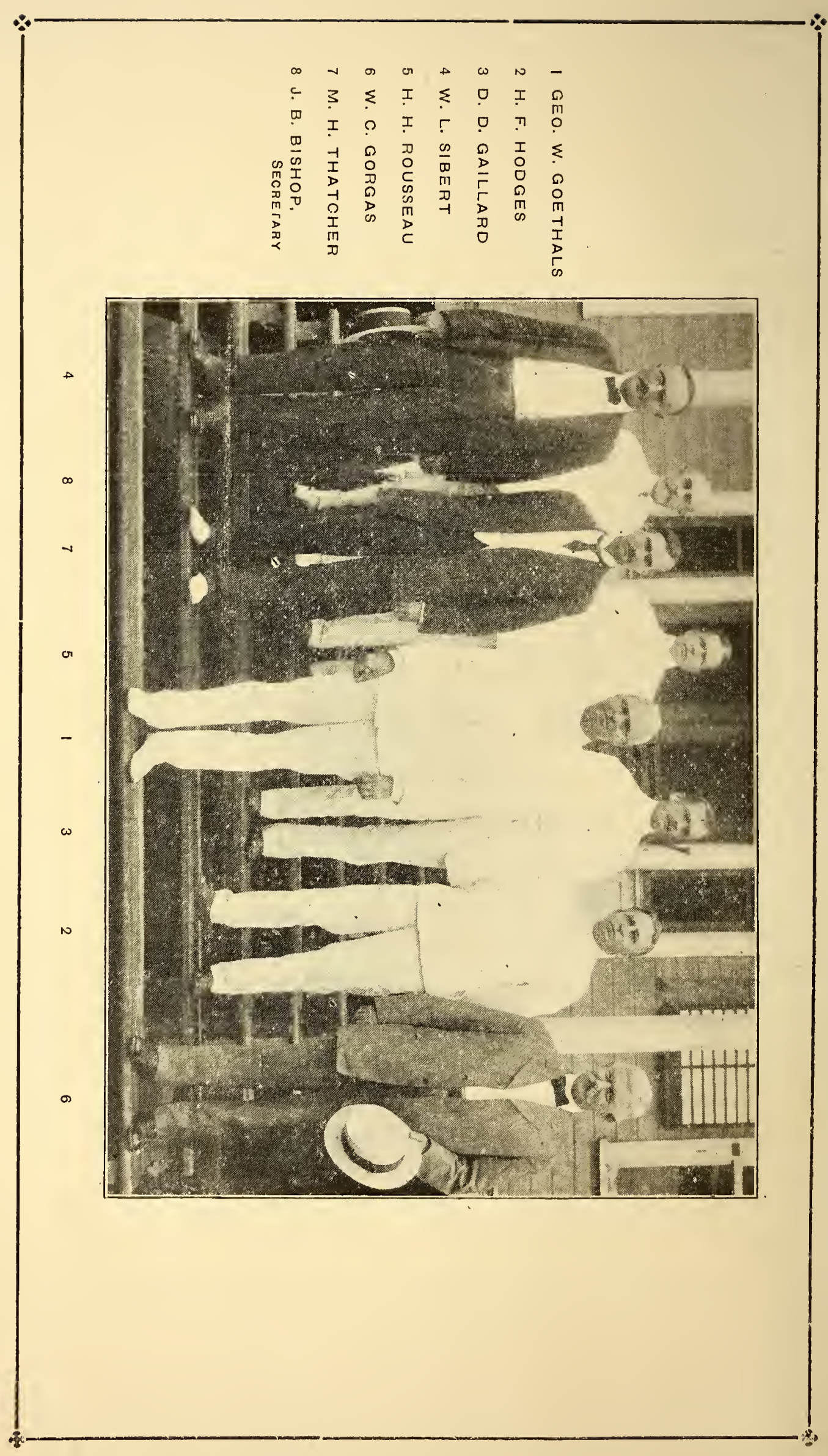




\section{From Colon to Panama.}

Along the route the tourist travels in crossing the Isthmus today, white men have been traveling for nearly four hundred years. Long before Jamestown was settled the Chagres River was a highway whose name was known to all the adventurers of Europe, and now when Jamestown is untenanted it is again to become a great highway, for the Panama Canal follows its valley half across the Isthmus. From the car window the tourist may see the valley up which men of our race have toiled for four centuries, and within two miles of the place where the railroad crosses the river (at Gamboa) is the village at which the river journey ended and the portage began on the old route to Panama. There was another way, all overland, from Porto Bello and Nombre de Dios to Panama, and the map of the Republic of Panama in this book shows the general route of the old trails. Elsewhere you will find further reference to the river, the trails, and the old cities, as the fortified places were called. In this place it is proposed only to follow the line of the railroad from Colon to Panama, telling briefly the story of each village along the route.

\section{Cristobal-Colon}

This city or overgrown village bears the Spanish name of Christopher Columbus, although for many years it was known as Aspinwall, the Panama Railroad officials having chosen to sall it by that name. But the Colombian Government insisted on Colon, and in 1882 when the French began to fill in the portion of the town near the canal entrance, they called their settlement Cristobal, so the joint town, American and Panaman, is called Cristobal Colon. The site was nothing but a coral reef backed by mangroveswamp when Columbus sailed past here on his fourth voyage, in November, 1502 , and it remained little more until the railroad builders began their work in May, 1850. That was only twenty years after the first railroad was built in the United States.

It would be wrong to conceive of Colon as having had an uneventful history merely because it is a city young in 
years, and even today bears the marks of a construction camp. As the Atlantic terminus of the Panama Railroad it has been a place of international importance ever since the first train crossed the Isthmus. A less prepossessing site for a city could scarcely be imagined, and yet its growth was natural, since it was necessary to locate the docks at this point. It is situated on the Island of Manzanillo, which was formerly cut off from the mainland by a narrow strait known as Folks River. The island itself was a coral reef upon which mangrove trees had taken root and grown up into a tangled mass, catching silt and gradually transforming the reef into a swampy island. Upon this the first shanties and stores were built by the railroad pioneers in June, 1850. In November, 1851 , two steamers, unable to land their passengers for California at the mouth of the Chagres River, disembarked them at Colon, whence they were hauled to Gatun on the railroad, there to take canoes for the river journey. From that time Colon became the center of the California transit trade on the Atlantic side, and the village grew rapidly and was very prosperous until the completion of the transcontinental railroad in the United States in 1869, when it declined and once more became only the railroad terminus.

In Otis' handbook of the Panama Railroad, published in 1862, there is a picturesque description of the city of Colon (Aspinwall), which was then at the height of its prosperity as a stopping place for people making the journey to and from California. There were hotels and shops, and warehouses, half a dozen steam and sailing-vessel lines made it a port of call, and the railroad colony was already firmly established in not unattractive surroundings, of which the writer says :

Upon the sea beach at the north end of the island you will first observe the hospital of the Railroad Company, a couple of large airy buildings surrounded by generous tiers of piazzas, about which a general air of tidiness and comfort prevails. Although built for the exclusive use of the company, strangers requiring medical aid are permitted to avail themselves of its advantages. A little to the left is a long wooden building, which contains the lecture-room, library, and clubroom of the employes of the company. A well-selected library of several hundred volumes, and the standard periodicals and journals, may be seen here; there are also materials for a snug game of billiards, backgammon, or chess. Three or four neat little cottages come next along the line of the beach, the residences of the principal officers of the company, with little garden plats in the rear and an occasional coco tree throwing pleasant shadows over them. A little farther on is a fine corrugated iron dwelling, the residence of the 
Royal Mail Steam Packet Company's agent; next to this is seen the general rendezvous of the Railroad Company's officials (usually known as the mess house) imbedded in a grove of coco and banana trees. Within fifty yards of the rolling surf, the sea breeze ever laying through the surrounding foliage, it would be difficult to find a more desirable tropical residence. Still farther on to the right are the buildings of the terminus, car repositories, etc., and machine shops whose tall chimneys send up steady columns of smoke, while the ring of many hammers breaks cheerily upon the ear.

First the city built up along the reef near the sea, then back into the swampy land behind the reef. The French added to it in the early 80's by dredging material from their canal channel and depositing borrowed rock and earth upon the swampy land, making a foundation for their employes" village, now a village of American Canal workers, known as. Cristobal. When the American Canal builders came here in 1904, Colon had ten thousand people, and about nine thousand of them lived in shanties built on piles. At high tide the houses were surrounded by water, so that no one could walk along the streets back of Front Street without danger of falling into the mire. Since then the town site has been filled in, and the Panamans and the Panama railroad are paying for the work. Colon is clean, well drained, and healthful today, although it doesn't look it. It has $\mathbf{1 8 , 0 0 0}$ inhabitants, and there are 2,000 in Cristobal. In 1870 Colon had 8,246 inhabitants, and in 1896, 13,203.

Colon has suffered from several destructive fires, the more important being that of 1885 , referred to on page 127 , and that of March, 1911, when ten city blocks were burned and 1,200 people left without shelter.

The sightseer in Colon should begin where the settlement itself began in 1850, at the north end of the island, known as Colon Beach. On the site where

Washington now is being erected the new Washington Hotel. Hotel, a modern structure of reenforced concrete and hollow tile, the first eating house was built for the railroad employes; and arcund it grew up the railroad village. It was not an attractive place in the old days, except that the waves were then breaking on the reef just as they are now, and coconut palms were waving before the breeze; and yet to it came to live and give their life's work the men and women who built the Panama Railroad, and were identified with its early history. The eating house later gave place to a large frame structure which in time was itself enlarged. This was recently moved to a site 
behind the Episcopal Church, where it now remains in its original character as an employes' eating and lodging house. On a plat of grass in front of the old hotel, on a site now occupied by one corner of the new Washington, a monument was erected to the founders of the railroad, Aspinwall, Stephens, and Ghauncey. It is a shaft of red granite on a base of red stone with the busts of the three founders cut on the shaft near the base. It is to occupy the center of a flower bed at the entrance to the new hotel; that is, on the side dooking towards Colon, where it will be nearly hidden by plants and ferns, a merciful eclipse, since the monument is very ugly.

The new hotel accommodates 175 people, having 88 bed rooms, and contains all the baths, toilet rooms, writing and lounging-rooms, dining-rooms, kitchen with modern cooking apparatus, electric lights and fans, and other conveniences that distinguish a thoroughly up-to-date hotel. It is run by the Panama Railroad, that is, by an agent of the United States Government, just as the Tivoli, at Ancon, is conducted by the Canal Commission. The architecture is of the Spanish Mission style modified to suit the local conditions. Broad verandas look out upon the sea and between the hotel and the sea wall is laid out a garden, where palms, ferns, and other tropical plants have been planted At the east end, the sea wall is blocked out to provide a swimming pool, open on the sea side, 125 by 100 feet and from 3 to 9 feet deep; a baffle wall has been constructed in front to protect it from rough water. There is a breeze here all the year round, and the Washington Hotel will be as cool in July as Bar Harbor, and no warmer in winter time than it is in July. Like the other Government hotels, it will have no bar, but in other respects will be the same as a good hotel at an American summer resort.

The gray stone building in modified Gothic style, immediately west of the hotel site, is Christ Episcopal Church, which was built by contributions from the

Christ Panama Railroad Company and missionary Church, societies. It was dedicated in 1865 and, except Hospital, for a few years, when it was used as a ColomQuarantine. bian arsenal, barracks, and storehouse, has been a place of worship ever since. At first under the jurisdiction of the Protestant Episcopal Church of the United States, its government was changed to the Anglican Ghurch in 1883, when thousands of British ne- 


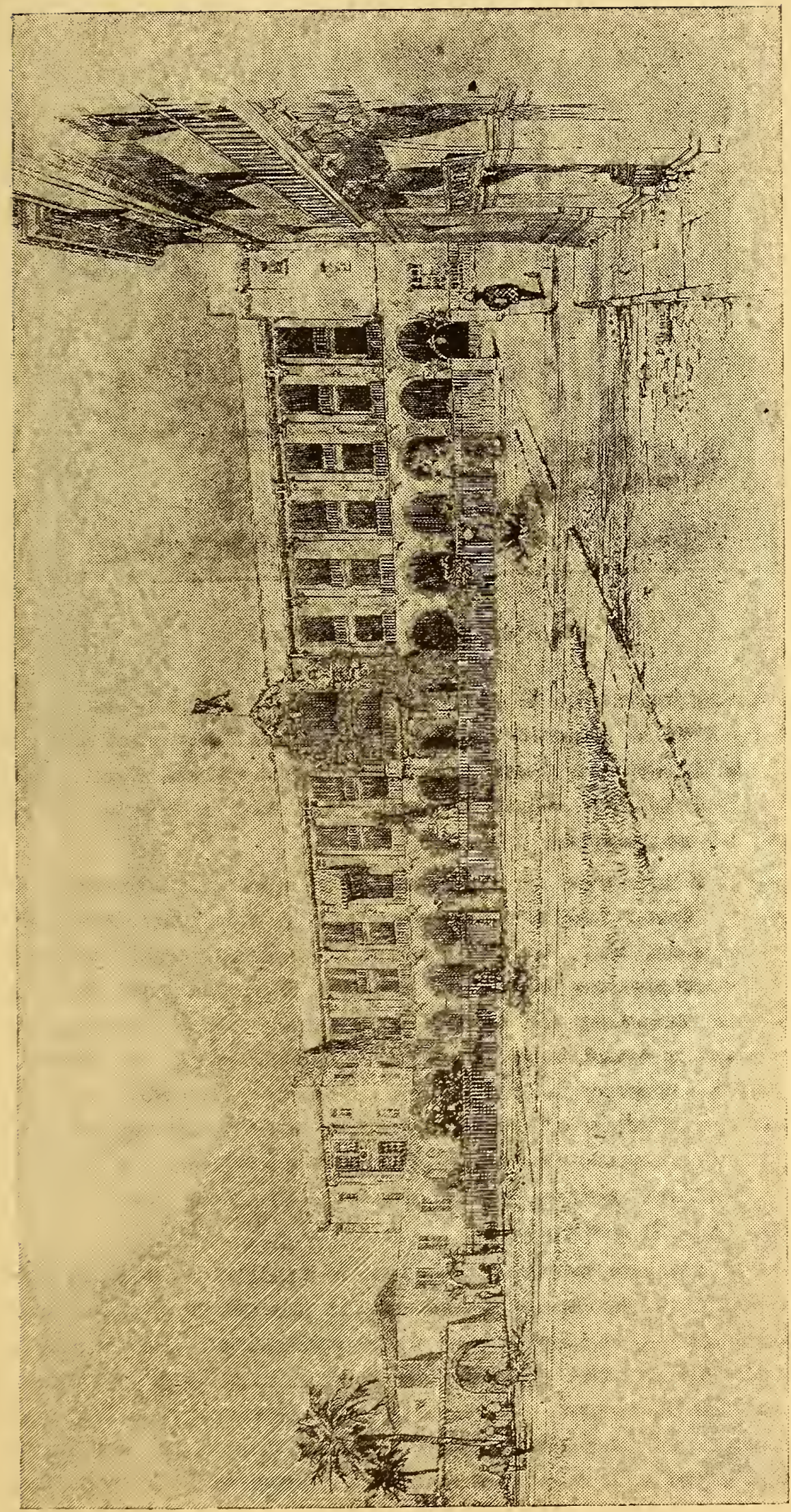

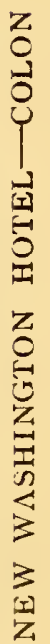




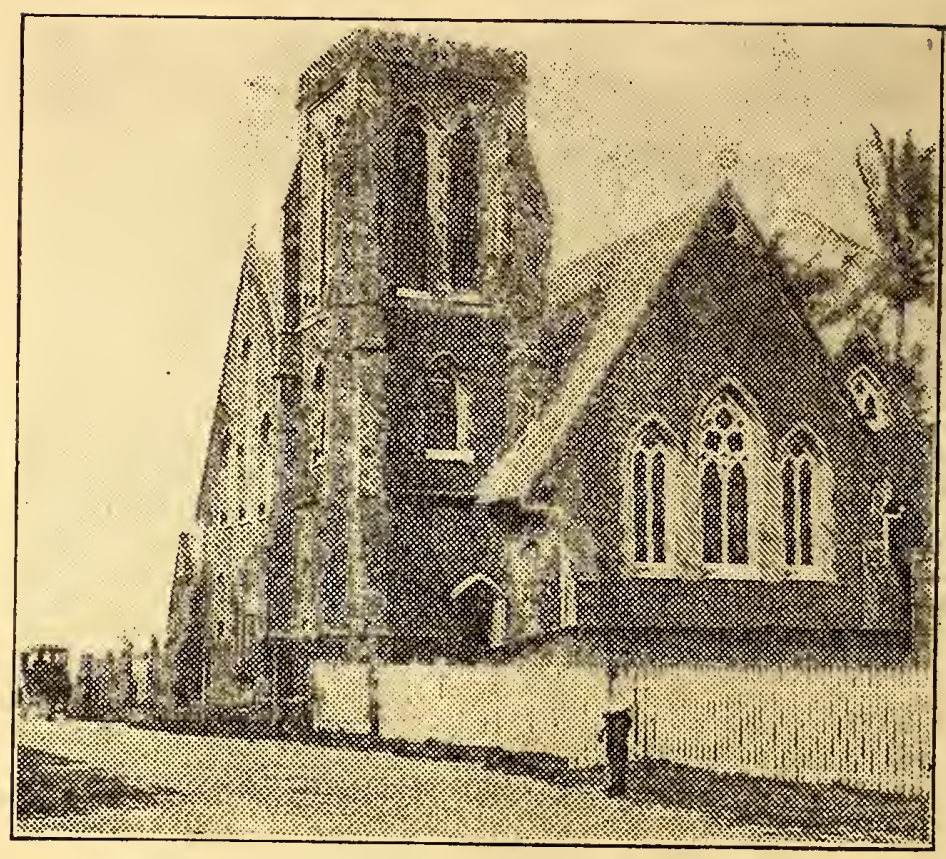

CHRIST CHURCH-COLON.

groes came from the West Indies to work on the Canal, and again in 1907 it passed to the American Episcopal Church, when the American canal work had been established. Both whites and blacks worship here, but the majority of the members are negroes.

Beyond the row of railroad employes' quarters, in the enclosure about half a mile west of the church, also fronting on Limon Bay, is the Panama Railroad and Isthmian Canal Commission hospital with 525 beds, and modern means for treating all kinds of illness. This hospital has. grown from a small field hospital established by the Panama Railroad Company in 1851. Immediately beyond it is the quarantine station at which persons from plague and fever ports must remain to complete their period of six or seven days' isolation before being allowed to cross the Isthmus. or enter the city of Colon.

On the beach between the site of the hotel and the piers. of the Panama Railroad Company is the office headquarters. of the railroad whence the superintendent and his subordinates direct the conduct of the railroad and steamship line on the Isthmus. Adjoining the line of piers immediately south of the office building and the hotel site is the Colon freight office of the railroad company. It was built in 1864 and rebuilt after the fire in 1885. This building has 
also served as quarters from time to time for Colombian troops, and within its walls in November, 1903, were concentrated the American residents of Colon and the half hundred marines sent there to defend them from the massacre threatened by the commander of the Colombian troops that had recently landed on the Isthmus.

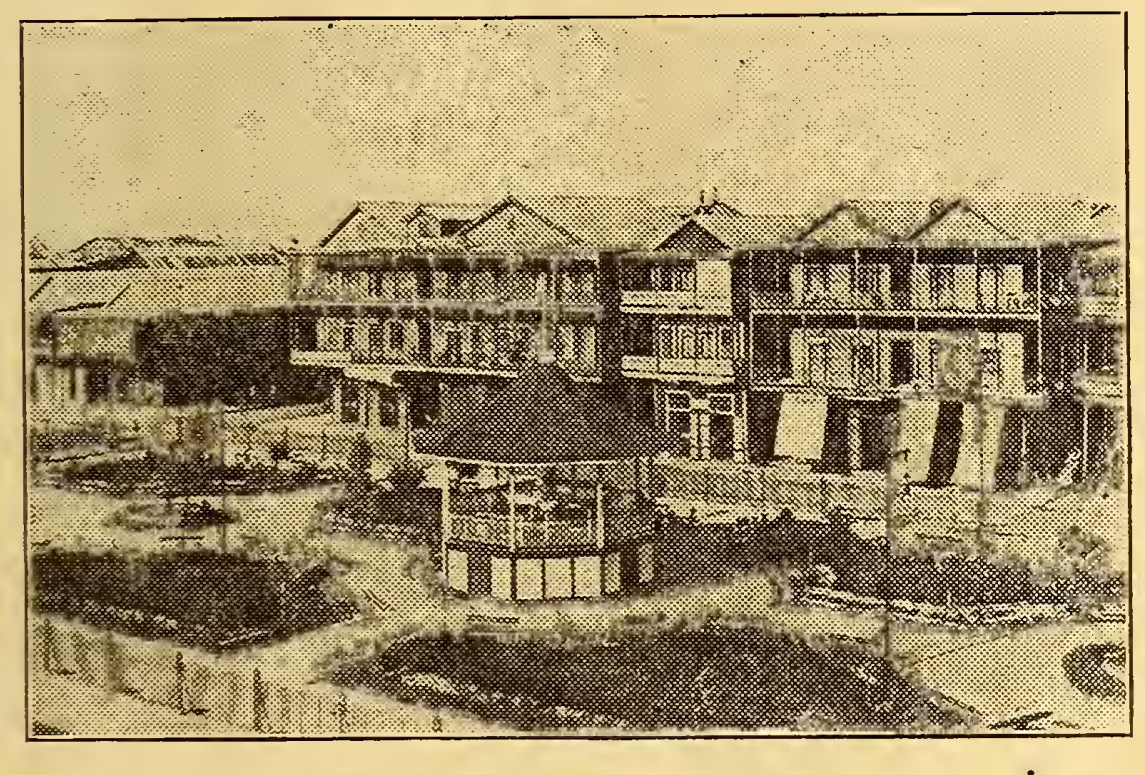

PLAZA-COLON.

Other buildings in Colon worthy of mention are the masonry structures of the Panaman Government-one a public school, and the other a municipal Other building; the frame building on the water buildings. front near the railroad station, which is the home of the Strangers' Club; the brick house adjoining it, in which the Isthmian poet, J. K. Gilbert, wrote his poems, now collected in the book, "Panama Patchwork," and the concrete block railway station. Owing to encouragement by the railroad company, which owns nine-tenths of the land in Colon, there is a distinct tendency on the part of merchants and others to build concrete structures. A Masonic hall is to occupy the block immediately back of the commissary building; the railroad is erecting a threestory building on Front Street, which is to be used as stores and living apartments; and other concrete buildings are in process of erection. 
Across the Canal Zone line in the village of Cristobal are the cold-storage and manufacturing plants of the Commissary system, a modern fire-station house,

Cristobal. and the old French Canal headquarters, on Cristobal point. One of these buildings was built for Charles deLesseps, son of the Canal promoter,

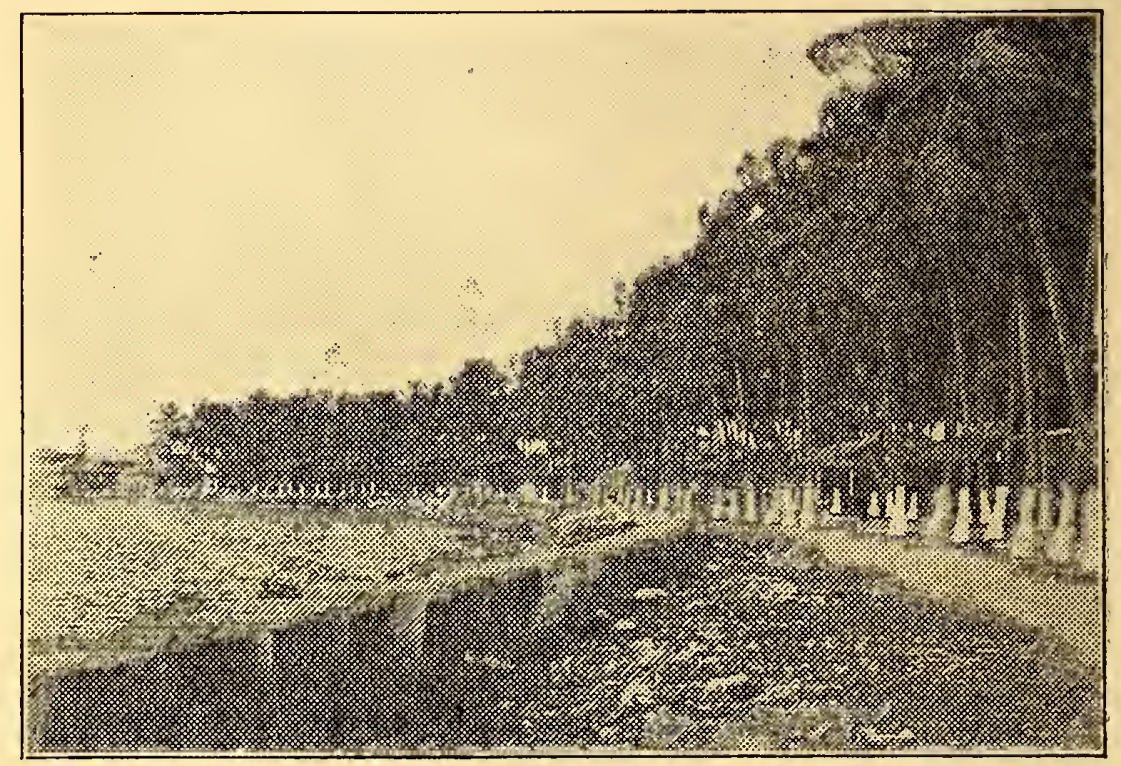

SEA FRONT-CRISTOBAL.

and was occupied by him and other canal officials during the French regime. It is now used as offices for the Commissary system and other branches of the Canal administration. Occupying a little knoll on the point is situated the statue of Christopher Columbus, in heroic Columbus bronze, in the attitude of protecting an Indian Statue. girl crouching by his side. It is said that he is supposed to be explaining away the terror of the girl, but Ferdinand de Lesseps said upon the occasion. of his visit in $\mathbf{1 8 8 0}$ that he was learning from the Indian "the secret of the straits," and in turn was explaining to her its profound importance. This statue was presented to Colombia in 1868 by the Empress Eugenie, and was set up in the railroad yard in Colon in 1870 , but upon request of Lesseps it was removed to Cristobal point. The construction of the docks at this point will again place it in a railroad yard, and it is proposed to remove it once more, this time to set it up in the garden in front of the new Washington Hotel on Colon Beach. 


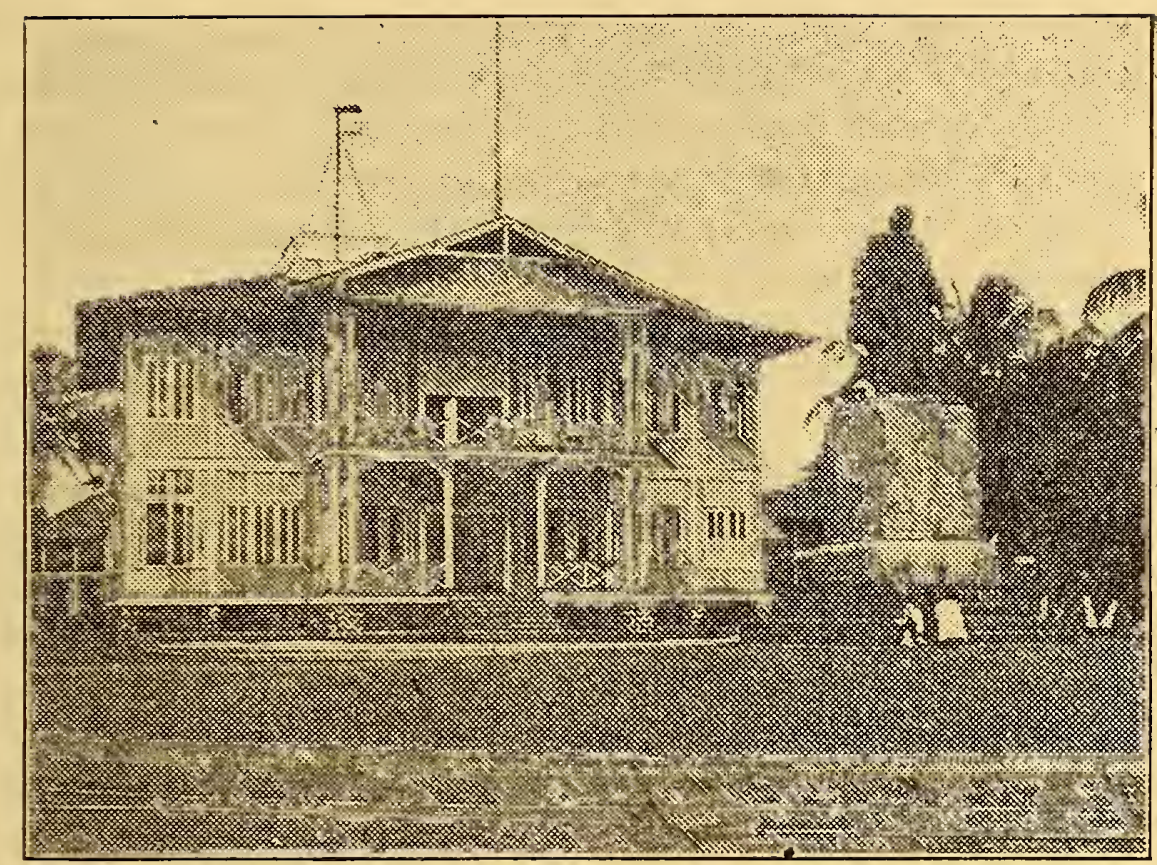

COLUMBUS STATUE AND LESSEP'S HOUSE-CRISTOBAL.

Construction work in progress in front of Cristobal is. that for a system of five piers enclosing ten docks which will be the Atlantic terminal docks for the PanaTerminal ma Canal. Each dock will be capable of berthDocks. ing ships 1,000 feet long, and the space between. the piers (300 feet) will be sufficient to allow two ships to enter and dock at one time without danger of collision.

Across the bay from Cristobal is the canal settlement of Toro Point, where live the men who are constructing. the breakwater at the entrance to the canal

Toro Point. and those who are building the fortifications, which are to guard the west side of the entrance. The fortifications for the east side will be on Margarita Island, about a mile north of Manzanillo Island on which Colon is situated. In what may be considered the back yard of the city are situated the Panama railroad shops, where the railroad equipment is erected and repaired.

Farther south along the line of the railroad are the unloading docks for canal supplies, the dry dock and marine

Mount Hope.

Shops, Storehouse, ceme-

tery. shop at Mount Hope, and the main storehouse for canal and railroad supplies. Here also, on the east side of the railroad, covering the knoll opposite the warehouse, is the Mount Hope Cemetery, which has been the burying: 
ground of Colon and Cristobal from their beginning. Its original name was Mount Hope, although there was a period during the French regime when it was referred to as Monkey Hill, on account of the presence there, in early days, of a number of the monkeys which are found in the woods all over the Isthmus.

At the Marine Shop the French erected the dredges and other equipment with which they carried on the Atlantic entrance work. Their plant was enlarged and the dry dock rebuilt by the Americans so that the equipment now in use in the Atlantic entrance could be repaired. Five dredges, half a dozen tugs, a fleet of barges, and a dozen small launches are kept in repair here. The work is in charge of Maj. Chester Harding, Assistant Division Engineer.

The original storehouse at Mount Hope was burned in April, 1907, and the main building, erected immedia tely afterwards, is of sheet iron with concrete fire walls dividing it into compartments which are connected by automatically closing doors. The stores consist of 12 , buildings with 249,000 square feet of space, and the stock on hand in 1912 was valued at two million dollars. One of the parts is a modern printing plant under the management of an American printer, $\mathrm{Mr}$. Albert P. E. Doyle. Its work includes The Canal Record, the Official Handbook, The Panama Guide, and all the stationery and other work of the Canal and Railroad, except the annual reports. Along the old French canal are the unloading docks with berths for three ships, and here nine tenths of the Canal freight is unloaded. The initial accounting for all this freight is done at the Mount Hope Depot, by the staff of the Depot Quartermaster, Capt. Courtland Nixon, who is in charge of the storehouses, printery, and docks, but 90 per cent of the freight is delivered direct to its destination along the Canal, only a small part being kept at Mount Hope.

A shopper's guide to Colon is published herewith, and by referring to the map of the city the tourist can readily

find the location of any shop with relation to

Shopping and one of the principal buildings of the city. Eating in Colon. In general it will be found that European and

Asiatic goods are cheaper here than in stores in the United States, but considerably more costly than in European cities. There are a number of novelty shops in which souvenirs of the Isthmus are sold, but one will find very little that is characteristic of Panama because there are few industries in the Republic other than agriculture. 


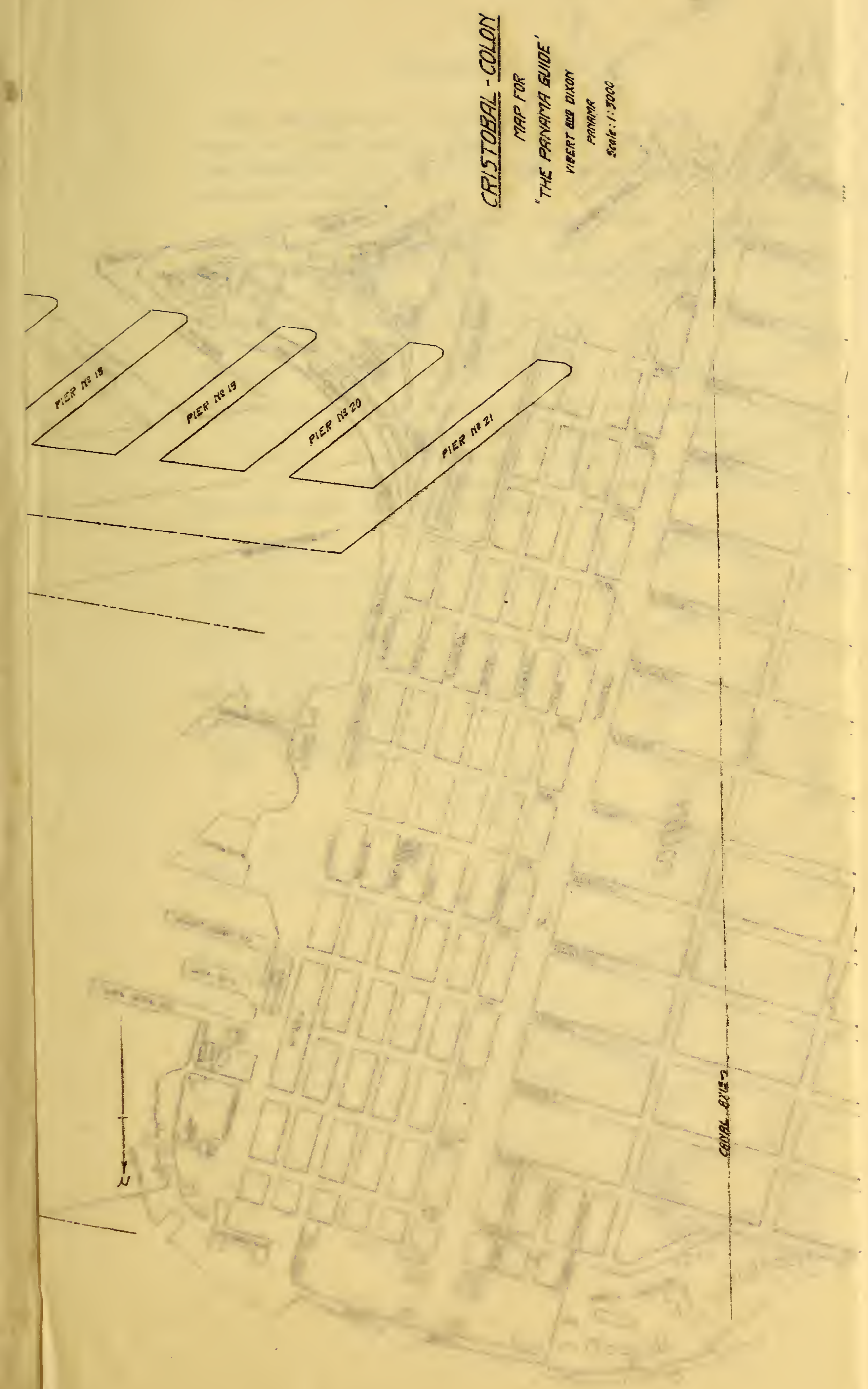





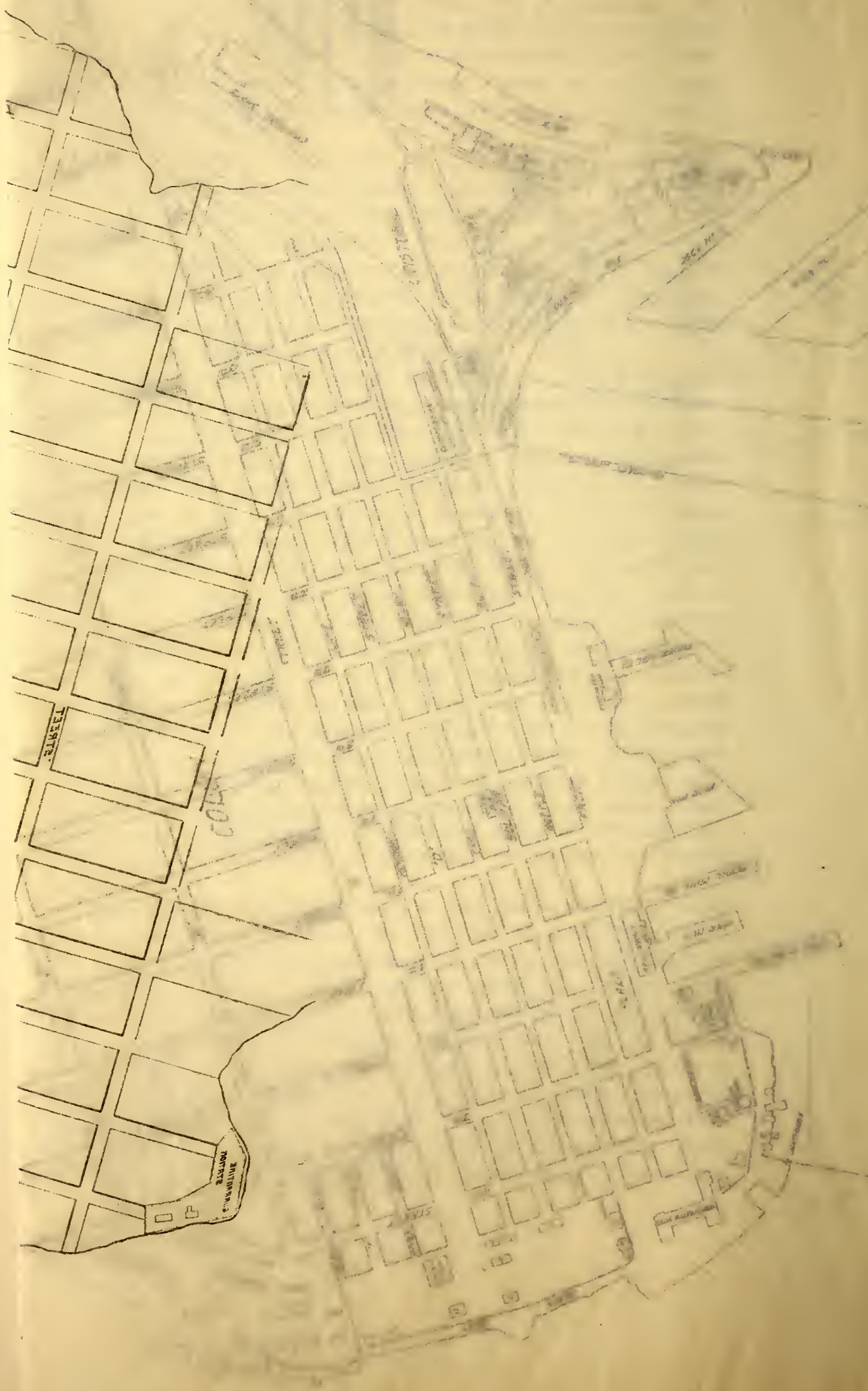


Only employes of the American Government on the Isthmus are permitted to buy goods at the Panama Railroad commissaries, and only coupons representing cash are received in payment.

There are not many good eating places in the city, because most of the people live in their own homes, and the balance, being nothing but bachelors, get along as best they can with the thirty-cent meals at the Canal and railroad mess halls, or in private eating clubs. One can always get a good meal in pleasant environment at the Strangers' Club, but few visitors are so fortunate as to have guest cards.

Coach Rates The rates for coach fare in Colon are given in Colon and the following table expressed in American curVicinity. rency. Panaman currency has the same face value as American, but the Panaman coin is twice as large as the American.

\begin{tabular}{|c|c|c|c|c|c|}
\hline One coach, per hour............ & ........... & $\begin{array}{l}\text { One. } \\
.75\end{array}$ & $\begin{array}{l}\text { PERSO } \\
\text { Two. } \\
1.00\end{array}$ & $\begin{array}{l}\text { Three } \\
1.25\end{array}$ & $\begin{array}{r}\text { Four. } \\
1.50\end{array}$ \\
\hline Between any two points in Cris- & One way... & .10 & .20 & .25 & .30 \\
\hline 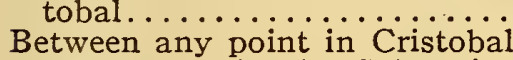 & Round trip & .20 & & & \\
\hline $\begin{array}{l}\text { and any point in Colon, in- } \\
\text { cluding Colon Hospital........ }\end{array}$ & $\begin{array}{l}\text { One way... } \\
\text { Round trip }\end{array}$ & $\begin{array}{l}.10 \\
.20\end{array}$ & $\begin{array}{l}.20 \\
.35\end{array}$ & $\begin{array}{l}.25 \\
.45\end{array}$ & $\begin{array}{l}.30 \\
.50\end{array}$ \\
\hline Between any point in Cristobal & & & & & \\
\hline $\begin{array}{l}\text { and any point in Colon beyond } \\
\text { or east of Colon Hospital . . . . }\end{array}$ & $\begin{array}{l}\text { One way... } \\
\text { Round trip }\end{array}$ & $\begin{array}{l}.15 \\
.30\end{array}$ & $\begin{array}{l}.30 \\
.50\end{array}$ & .40 & .50 \\
\hline Between Mount Hope Pumping & One way... & .10 & .20 & .25 & .30 \\
\hline $\begin{array}{l}\text { Station and I. C. C. corral } \\
\text { Between Mount Hope pumping }\end{array}$ & Round trip & .20 & .40 & .45 & .50 \\
\hline 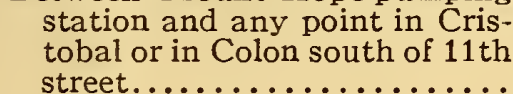 & $\begin{array}{l}\text { One way... } \\
\text { Round trip }\end{array}$ & $\begin{array}{l}.25 \\
.50\end{array}$ & .50 & $\begin{array}{r}.65 \\
1.10\end{array}$ & 1.80 \\
\hline
\end{tabular}

SHOPPER'S GUIDE.

Banks.

\section{Name Location}

International Banking Co..............Front \& 7th St.

Panama Banking Co Bolivar and 7 th St

Books, Periodicals, Souvenirs, Etc.

Beverhoudt Front Street, near 11 th......

Irvin \& Thomas. $13 \& 59$ Front St

Lince \& Co..................................Front St., Opp. Station......

Panama News Co.......................... In P. R. R. Station............... Panama Gem and Curio Co..........54 $\frac{1}{2}$ Front St.

Panama Guide All Book Stalls

Trotts' Novelty Shop. 33 Front St. opp. Station...

Vibert \& Dixon Front St. opp. Station.

Waterman Pens

French Drug Store

Drugs, Perfumes, etc.

Colgate \& Co.

Front St. opp. Station 
Name

Location

Page

Dry Goods and Notions.

B. V. D. Co. Front St. opp. Station.

Mueller \& $\mathrm{Co}$

Hotels and Restaurants.

Washington ... Colon Beach

Land Development.

Terrell (Fla.) Lands. Florida

Photographs, Developing.

City Photo Studio. 24 Front St. near 7th

Central American Plumbing and

$$
\text { Plumbing. }
$$

Supply Co. 66 Bolivar St.

Ullrich \& Co. Provisions.

Sewing Machines.

Pan-American Shoe Factory........ Bottle Alley \& 8th St.........

Compagnie Gle. Transatlantique..near P. R. R. office

Hamburg-American Co................. Beach near P. R. R. office..

Harrison \& Leyland Lines.

Panama Railroad Co.................... R. R. Station.

Royal Mail Co. Pier No. 3.

United Fruit Co. near P. R. R. office. Vacations in States.

Illinois Centrai Raiiroad Co Watches, Jewelry, Optical Goods, Etc.

J. L. Kerr. Front \& 11th St.

Mindi.

At this point the Mindi River flows into the bay, and here also the French Canal Company had begun to construct a viaduct for the relocation of the Panama Railroad, required by the construction of the canal: The stone piers for the viaduct may still be seen in the fields on the east side of the railway tracks. The section between Colon and Gatun through which the train is now passing was one of the most difficult for the builders of the Panama Railroad to construct their line through, because it is low, marshy land. The old line ran a few hundred feet west of the present line up to Gatun, but it was necessary to abandon this in 1909 on account of the construction of Gatun Dam, which runs across the old location of the railway. On the left, as the train nears Gatun, may be seen a large dyke of earth paralleling the railroad track. This was constructed for the purpose of holding material from the hydraulic excavation of the canal immediately north of Gatun Locks. 


\section{Gatun.}

As the train enters Gatun (name probably derived from "gato", (cat,) as applied to the smooth-running river that joins the Chagres at this point) one may see on the right the walls of the locks rising above the level of the surrounding country, and beyond them the long low mound which is Gatun Dam. The steel towers seen on either side of the lock walls support the cableways on which concrete is handled from the mixers into the forms. The first stop is at New Gatun, and here, by looking out of the winNative Town. dow, one may get an idea of the two sections into which every large village of the Canal Zone is divided-the "native" and the "American" sections. The native section is not inhabited exclusively by natives of Panama, but largely by West Indian negroes and European laborers. It is the part in which one finds the saloons, small retail stores, and the lodging-houses and apartments which are sogenerally preferred by the negro laborers to the quarters furnished free by the Government. The "native" town is the center of the non-American life. Beyond it is the American settlement, a series of frame houses, all of one type, varying in size according to the salary of the official or employe who occupies them. Here are the family and bachelor quarters for Americans, the mess hall, lodge hall and church, post office, commissary store, and administrative offices.

Hold on to your hat when you alight at Gatun because this is the breeziest place on the Isthmus. The tourist will do well to go direct to the building on

Locks, Dam, the hill, in which is the office of the Division Channel. Engineer of the Atlantic Division, Lieut. Col. Wm. L. Sibert, and the administrative staff under his direction. From the veranda of this building the best view of the canal that can be obtained from any one point is afforded. Looking northward one can see the waters of Limon Bay, the masts of shipping in the harbor of Cristobal and Colon, and, nearer, the dredges at work in the Atlantic entrance to the canal. Looking into the valley the locks are seen, and beyond them the dam in process of construction. The plans of the locks and dam are referred to in the section of this book devoted to the canal. The method of construction can be seen from the veranda.

The locks are placed in a hill on solid rock, and are three parallel concrete çhambers forming three distinct steps for 
the purpose of lifting ships from the sea level to the lake section or lowering them from the lake to sea level. The dam is composed of two long mounds or toes of rock and earth running parallel to one another and, on the natural level of the ground, about 1,200 feet apart. Between these mounds an impermeable mass of sandy clay is pumped by suction dredge. The water flows off, allowing the impermeable core to remain between the rock toes. About half way across the valley the spillway is being constructed through a hill for the purpose of regulating the surface of Gatun Lake, in order that the water in flood-time may not

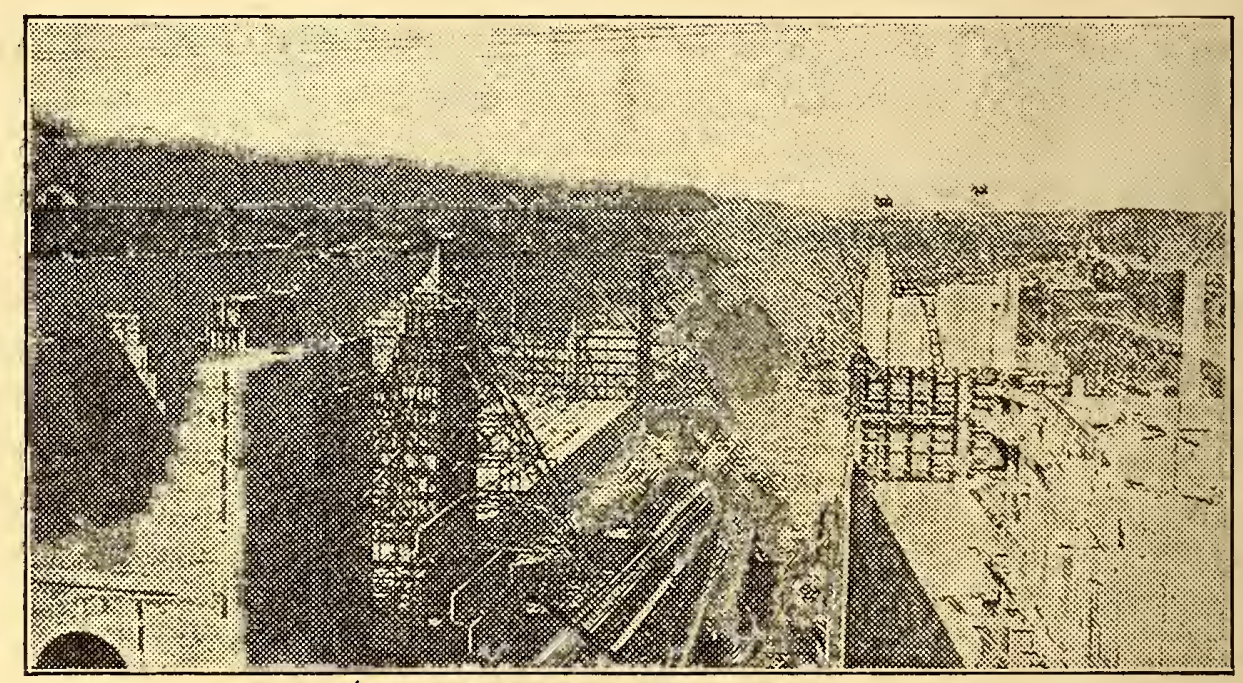

CONSTRUCTION OF CONCRETE WALLS OF GATUN LOCKS.

rise so high as to threaten the destruction of the dam. On procuring permission from the office, the tourist may walk down to the locks and cross the chambers upon one of the construction bridges, or, if he is ambitious and willing to undertake a fruitless climb, he may descend into the locks themselves. From the construction bridges one gets a very good idea of what the locks are like, for he sees them in all stages of construction, from the completed walls to those now in process of building, and from the completed gates at the south end to the gates now being erected. (See page 78 .)

Gatun was not always a brand-new village perched on a hill overlooking the valley. Says The Canal Record:

The old village of Gatun, which lay on the river flats below the present town was abandoned in 1908, and the site is now covered by feet of rock and earth under Gatun Dam. At the time it was andoned, the village contained a church, priest's house, szhool, a 
dozen small shops, and ninety or more small houses of all descriptions, from the bamboo hut with palm thatch to the typical sheet iron roof shanty. Most of the buildings were moved to the new townsite, now known as New Gatun. The railroad line also ran through the dam site and as soon as the present line into Gatun was opened, this likewise was abandoned, and the station building was razed. By the middle of 1909 the last vestiges of the old village had disappeared before the encroaching work on the dam.

The antiquity of the place is uncertain, because none of its buildings were of masonry. In his narrative of the pirate Morgan's march to Panama in August, 1670, Esquemeling says: "The first day they sailed only six leagues, and came to a place called De los Bracos. Here a party of his men went ashore, only to sleep and stretch their limbs, being almost crippled with lying too much crowded in the boats. Having rested awhile, they went abroad to seek victuals in the neighboring plantations; but they could find none, the Spaniards being fled, and carrying with them all they had.'"

The location on the river corresponds to that of Gatun, for six Spanish leagues equal about nine miles, and even if the situation of De Los Bracos is not identical with old Gatun the narrative indicates that the region thereabouts was somewhat settled. It is also known that the Spaniards had erected a fort on a hill 120 feet above the river, overlooking the town, which was probably one of the outposts they had established at various points along the isthmian trade routes. Evidences of the old fort are found to-day, and the site is shown on the original land-map made for the Panama Railroad in 1855. At that time the village had about one hundred buildings of all kinds. Writing of it in 1861 Otis says it was a village composed of forty or fifty huts of cane and palm. In the early days of the California immigration it was the first stopping place in the canoe journey up the Chagres, where "bongo-loads of California travelers used to stop for refreshments on their way up the river, and where eggs sold four for a dollar, and the rent for a hammock was two dollars a night."

In 1881 the French chose Gatun as the site for one of the canal residencies, erected machine shops there, and built a number of quarters for laborers, calling the new section, "Cite de Lesseps." This continued as a center of the work of excavation until 1888, when all operations ceased, not to be resumed here until 1904.

When the Americans arrived in 1904, Gatun was the center of a comparatively large river trade. Bananas and other produce from the Gatun, Trinidad, and Chagres Rivers, were brought there for transhipment by rail, and for sale. Once a week, a shipment of from seven to nine carloads of bananas was made, and on the shipping day, as many as a hundred canoes would tie up at Gatun.

\section{The Lake Villages.}

From Gatun the original course of the railroad lay through the bottom-land along the Chagres River. But on account of the fcrming of Lake Gatun, the reservoir for the upper level of the canal, the line now leaves the river course, and turning eastward makes a detour around the east side of the lake region. Just before the old line was abandoned The Canal Record printed the following article: 
The villages between Gatun and Matachin will be covered by the water of Gatun Lake. They have never been important in the sense of size, or as the center of any peculiar type of life. In fact they are little more than jungle hamlets, yet they have a distinct place in American history, because they were known to European civilization many years before Jamestown was settled or Massachusetts Bay was an English colony.

In The Canal Record, November 29,1911, there was republished a letter in which attention was called to the fact that the names of some of these villages appeared on the map published with Esquemeling's narrative of the Buccaneers in 1678. Most of them antedate that time, for they were not named by the English who plundered with Morgan, but are spoken of in Esquemeling's book as places already known, and invariably they bear Spanish names. It is probable that most of them date from the early days of navigation on the Chagres River, when it was one of the most-used routes for commerce across the Isthmus. Among these are Ahorca Lagarto, Barbacoas, Caimito, Matachin, Bailamonos, Santa Cruz de Juan Gallego, and Cruces (Venta Cruz).

As early as 1530 Spanish ships sailed down the coast from Nombre de Dios and entered the Chagres, whence their goods were transferred to canoes and taken up the river as far as

The River Cruces, a distance of 36 miles from the river mouth, Route. near the point where Culebra Cut begins. From Cruces they were taken overland to Panama. At times of high water, when the stream could be navigated readily by shallow boats, this was the easiest route across the Isthmus, although the trails from Nombre de Dios and, after 1586, from Porto Bello, were kept open and were much used by pack trains. The harbor at the mouth is not so safe as those at Nombre de Dios and Porto Bello, and yet that the trade by this route was not inconsiderable is attested by the fact that the entrance to the Chagres was guarded by a fort (San Lorenzo). The river hamlets were of the type of the settlements that grew up along the highways, during the days of travel by coach and saddle, and their people probably subsisted as much by the trade they drove with travelers as by the products of their own fields. Yet Esquemeling speaks of cultivated fields, so there was undoubtedly some farming along with the travel trade.

The river trade became steadily less after the reign of Philip II, because Spain's monopoly was gone, and the all-water route to Peru by the Strait of Magellan was found less dangerous. But this was because the trade itself was less, for the Chagres route continued in use up to the time of the completion of the Panama Railroad in 1855. Since then the villages in the lake region have been "way stations," with two brief periods of prosperity-one when the French were working near them, and the other when the Americans were carrying on their operations. (See reference to abandonment of Isthmian route, page 119.)

The region in which these lake settlements are situated will probably not be under water before August, 1912, but the railroad track was torn up in February, and therefore the native hamlets and American canal settlements are being moved, the houses torn down to be erected again elsewhere, or in the case of shacks merely abandoned in the jungle. It is difficult to persuade some of the nhabitants that the inundation will ever take place. One ol d bush 
settler, after receiving repeated warnings heedlessly, ventured it as his opinion that the Lord had promised never again to flood the earth. Such people as these will be assisted in their moving, because the present hamlets will be isolated when the railroad is torn up and in case of a sudden rise in the river, with the backing up of water after the Gatun spillway dam is raised, it would be difficult to rescue them.

In this blotting out of the river hamlets and of one of the world's historic trade routes, nothing of value will disappear-only a few shabby hamlets, and a hundred or more isolated huts in the junglewhile the river route will give way to the canal, and the railroad to a straighter and better line outside the lake area above all danger of flood.

In the hamléts and the jungle there are three distinct types of buildings, in addition to the quarters for Canal employes. Of these the most picturesque and primitive is the open hut Jungle in the jungle, which consists of a palm thatch raised Hamlets. about eight feet above the ground on bamboo poles. Here a bush family has its incongruous being, for this jungle home is often within sight of the railroad trains, and within it one sees plantain being fried in a modern kettle over a modern brazier, while the drinking water is dipped with a gourd from a square, 5-gallon-capacity oil-can. A little more advanced type of dwelling is the pretty hut made of closely set bamboo sticks, sometimes plastered with mud, and with the broad overhanging thatched roof, in which lizards and bugs rustle about day and night. There are none of the more substantial native huts, found in some of the villages in the interior of Panama, built of clay blocks and covered with overhanging pantile roofs. The third type of house, although more modern, can scarcely be considered an advance on the bamboo hut. It is built of lumber and covered with a corrugated-iron roof. Old residents of the Isthmus say that this type is due to the easy pilfering of lumber and roofing iron, left in storehouses and on isolated buildings by the French canal builders, and that it was unknown before 1885. Usually these buildings have been arrested in dissolution by patches of soap boxes or tin flattened out from old cans, which gives them a motley look. The village stores are little better than this latter type of dwelling. Here and there one sees in a settlement of such nondescript houses, the trim little cottages built by the French and more recently used by the Americans; and the more airy and well screened quarters of the American canal period. These, however, are late additions. The original villages were jungle settlements existing because of the isthmian transit.

The next settlement of any importance up the river from Gatun is Bohio. Between these two villages are three hamlets-Lion Hill, Tiger Hill, and Ahorca Lagarto-none of them num-

Bohio. bering over half a dozen huts and without any apparent reason for existing except that some bush negroes or natives happened to settle there. The two first mentioned are essentially railroad camps that have existed since 1851, when they were successively the terminus of the road. Ahorca Lagarto, however, is on a bend in the river, and may well have been a resting place for the cramped travelers in canoes. Of the origin of its name Otis says: "Ahorca Lagarto, 'to hang the lizard,' deriving its name from a landing-place on the Chagres near by; this again, named from having, years back, been pitched upon as an encampment by a body of 
government troops, who suspended from a tree their banner, on which was a lizard, the insignia of the Order of Santiago." In 1908 it had sixty-two inhabitants, of whom three were white, two yellow, and the balance negro.

Bohio appears to have been another bush hamlet in 1862 when Otis wrote. Until recently it has been called Bohio Soldado (Soldier's Home.) The French made it the site of one of their district headquarters in 1882, erected a machine shop on the west bank of the river and did considerable work there under the old sea-level plan for a canal, which was excavated to this place to a sufficient depth for light draft boats. Here as well as at any place can be seen today the plan of the sea-level canal, which included the main channel and two large diversions or drainage ditches one on each side of the canal proper.

Under the French plan for a lock canal, Bohio was the site for the first dam, and the excavation for the locks at this point can be seen in one of the hills on the opposite side of the river from the railroad. As it has existed during the American regime the village has been a relic from the French period. Such surveys, investigations, and excavation as were necessary here were done by men occupying the French houses. In recent years Bohio has been the center of a small local trade in vegetables, brought in from the jungle by canoe and pack animals, in exchange for groceries and liquors sold in the Chinese and native shops. At the time of the official census in 1908, it had 526 inhabitants, of whom 447 were colored and native, 69 white, and 10 Chinese.

At Bohio the Americans carried on investigations in 1904 and 1905 to determine wheiher that location would be used for locks and a dam, and in 1909 excavation by hand and with steamshovel was carried on to remove a small hill and part of a dump made by the French, which stood in the canal prism. Across the river, where the machine shops were situated in the French days, and where they carried on work for the lock emplacement, the edge of a hill is now being removed by a contractor. The work at this point is typical of all that between Gatun and Culebra Cut, consisting as it does of the excavation of small elevations in the canal channel and the toes of the hills that project into the prism.

Near Bohio are the hamlets of Peñas Blancas and Buena Vista' both on the river, and each merely a collection of huts of various

descriptions. Frijoles (beans) is the next railway

Frijoles. station, a village of 784 inhabitants in 1908, of about a thousand when it became a center for relocation work on the Panama Railroad, now being rapidly deserted. Here for many years an old Frenchman ran a distillery in which he made rum of such good quality that he boasted that it was sold in Colon to rectifiers who made it into "genuine French cognac." One of the familiar sights of this hamlet is the village washing-place, a pool near the railroad tracks, formed by the swirling of the water in the Frijolita River at a point where it is turned at right angles to its previous course by the interposition of a bank of clay and rock. The method of washing clothes among the lower-class natives and West Indians can be observed here. This also is locally known as the place where one may buy bananas of peculiarly delicious flavor. 
Frijoles is mentioned in Otis' guide book published in 1862 , but the next village, Tabernilla (little tavern), although it appears on the Harrison-Arosemena map, is not. It was one

Tabernilla. of the centers of the French works, and there was a small field repair shop at this point, with a few buildings that served as quarters for the working force. During the American occupation it became a village of over two thousand inhabitants (2,079 in 1908), because here is situated the largest dumping ground on the canal work. The location was chosen in 1906 because it is on the main line of the railroad, outside of the canal prism and afforded a plot of ground two miles long and almost as wide for wasting of spoil. In all about sixteen million cubic yards. of material were wasted here, all of which will be below the level of the lake. The dump was abandoned at the close of 1910, and immediately the village population decreased, the people remaining there being largely employes with families who could not procure quarters elsewhere. These are now being moved because the demolition of the place is under way.

Between Tabernilla and San Pablo the railroad crosses the Chagres River at Barbacoas. The original bridge was built of wood, but early in the history of the railroad it was replaced

Barbacoas by a bridge of six wrought-iron through-plate-girder Bridge. spans ranging from 101 to 109 feet in length, supported upon seven masonry piers. This bridge is mentioned by Otis in 1862, and is said to have been one of the first of its type ever constructed. It was not built however to carry such heavy tolling stock as that placed on the road by the Americans, and so the three channel spans were replaced in 1908 by heavier girders, while the floor system of the three remaining spans of the old bridge were reinforced.

San Pablo (St. Paul) was originally a plantation worked by Catholic priests. It was a railroad station in 1862, was a laborer's San Pablo. camp in the French days, and during the American occupation has been a small canal village. It also is being demolished, and the last excavation in the lake region is now in progress there. Across the Chagres River from San Pablo is Caimito, one of the names found on Esquemeling's map. It was a canal labor camp in the French time and also under the Americans until the work at that point was finished Of this class, also, is Mamei, likewise a railroad station in 1862, and little more than that today, although it was the location of several quarters for Canal workers a few years ago.

Gorgona bears the name given by Pizarro to an island off the coast of Colombia, near Buenaventura, because he found around it such treacherous currents. It may be that this name

Gorgona.* was adopted arbitrarily, or that the Chagres River travelers found in the river at this place some eddies. that reminded them of the currents at Gorgona Island. Of this place Otis says: "The native town of Gorgona was noted in the earlier days of the river travel as the place where the wet and jaded traveler was accustomed to worry out the night or a rawhide, exposed to the insects and the rain, and in the morning if he was fortunate regale

*Gorgona means sea-fan. The island off Colombia was named after th * zoophyte. The whirlpool took its name from the island which it is near.

For Balboa Hill see page 207. 
himself on jerked beef and plantains. In the French time large shops were situated here, at the point where the Americar shops now are, known as Bas Matachin.

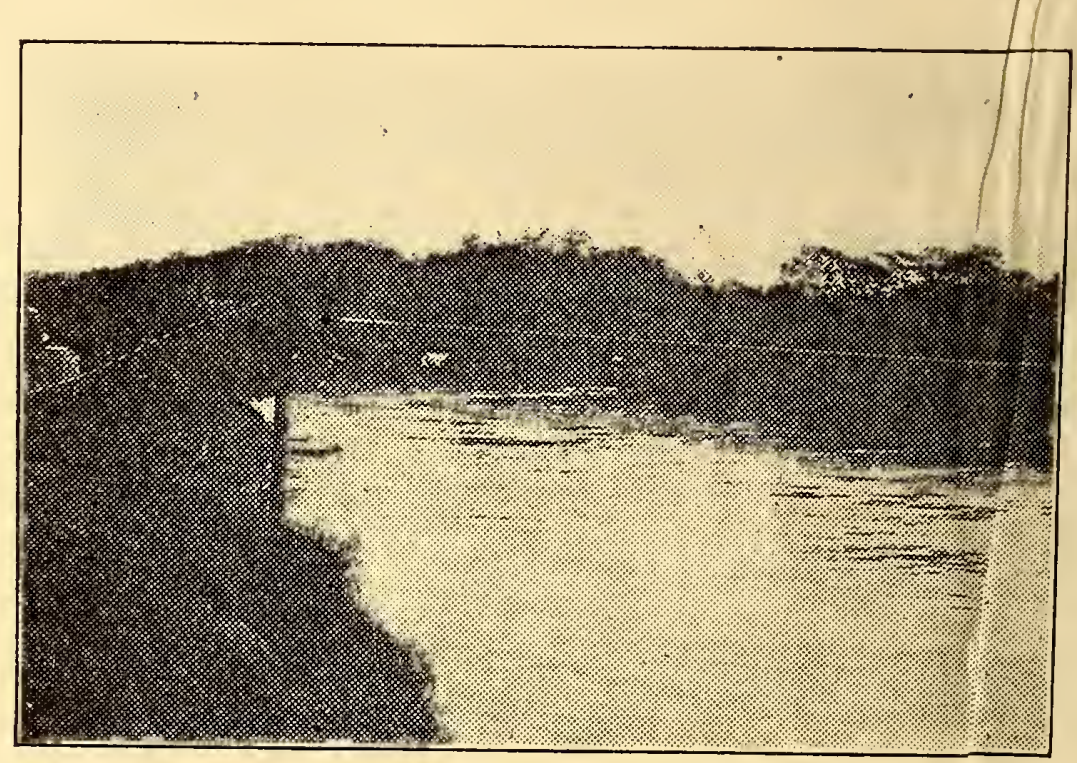

SCENE ON THE CHAGRES RIVER AT GORGONA.

Gorgona should not be classed with Gatun and Bohi as a purely jungle hamlet, because it appears to have been a settlennt of some size long before the railroad was built. It was one of te places at which the river travelers stopped for the night, and all sout it were cultivated farms. At the time of the first Canal Zce census in 1908 its inhabitants numbered 1,065 whites, 1,646 bcks, and 39 Chinese a total of 2,750 . The population has incresed owing to the expansion of work in the shops. The site of the lops and the lower parts of the village will be covered by the water (Gatun Lake, and therefore, the shops will be moved in about a yur to the site reserved for the permanent marine shops at Balboa.

This is the Spanish word for butcher, ancthis village, or the site of it, also appears on Esquemeling's tap. Therefore the current Isthmian-fo! etymology

Matachin. that it is a combination of the w'ds "matar," to kill, and "Chino," signifyin a wholesale death among Chinese laborers engaged in thrconstruction of the Panama Railroad, is erroneous. For ears this was the point at which trains from Panama tciolon passed those going the other way, and it had som local importance on that account, because the wait lre of ten ran as high as half an hour. In the time of tirst French company it was a labor camp, excavation as carried on here, and a few miles below, at the point tey called Bas Matachin, the shops were situated. These ops have since 
been enlarged and refitted into the present Gorgona Shops. The Americans also did considerable excavation at this point. It is the starting place for canoe trips up the Chagres River. As soon as the Gorgona Shops are moved to Balboa, the cause of existence of Matachin as a camp of canal laborers will have ceased and the village will again sink into a hamlet. In 1908 Matachin had 2,042 inhabitants, of whom 698 were whites, but its population has greatly decreased since 1909 , when excavation at this point was completed.

One other point in the lake region, on the abandoned line, is worthy the tourist's knowledge. In all but one spot the location along the river was good, Black Swamp. and that spot lies about five miles south of Gatun and is known as the Black Swamp. It is simply a swamp over which it was difficult to construct a railroad line, because the weight of the embankment and of the rails and rolling stock was so great as to displace the light, water-impregnated material underneath. On this account the road sometimes sank into the swamp. This was particularly true when the Americans placed the new heavy rolling stock upon the railroad in 1905, and from that time until 1908 this section of the line required constant attention.

In the effort to form a fill over which the trains could pass safely a number of old French dump-cars were thrown in bottom-up and thousands of tons of earth and rock were dumped there, only to sink into the swamp and afford but temporary relief. In 1908, however, the railroad engineers succeeded in constructing a trestle and filling it with cinder and other light material which successfully withstood the traffic up to the time when the railroad was abandoned in January, 1912. There is no subject on the Isthmus to which the chronic liar turns with greater joy than to the Black Swamp. The tourist will make a mistake in interrupting him or indicating in any way that he disbelieves the tales. Almost invariably they are untrue, but almost as invariably they are interesting. Soundings made in 1908 showed that the solid bottom beneath the swamp is 185 feet below the surface. It is an interesting comment on the stories that the watershed of the Chagres will not hold the water impounded by Gatun Dam, to know that this swamp has remained here, four feet above the level of the river, ever since the railroad was constructed in the middle of the last century. 


\section{The Relocation Country.}

Returning now to Gatun from a side trip that the tourist will hardly take, and yet which must be considered because of the historic interest of the old river towns and the former route of the railroad, the traveler takes the train over the new line of the Panama Railroad, known as the "relocation."

From Gatun to Pedro Miguel the country through which the railroad runs is "new;" that is, it is jungle little touched by the transit life until January, 1912. T'here were settlers in the bush all along the river, but they make little impression on the jungle, merely planting a few vegetables, and making trails from their homes to the main trails. The village of Monte Lirio was a typical "bush" hamiet before the railroad work was begun, its houses of bamboo and thatch, or board and thatch, its streets muddy, and sanitary conveniences none. It drowses on in much that condition now, while near it is the new Monte Lirio, known as Mitchellville, so named after a foreman popular with the workers. At various points along the line, town sites have been laid out in order that people driven from their homes in the Lake Region may have somewhere to rebuild. On either side of the train as it passes through this section may be caught pretty glimpses of the jungle, the trees and plants always green, those that dry up in the dry season being so few as to make little impression on the general color-scheme.

One half mile north of Monte Lirio the railroad crosses an arm of Gatun Lake, which reaches up in to Panama territory by way of the valley of the Gatun River. The bridge over this arm of the lake is 318 feet long and is built in three spans, two of them composed of fixed girders 103 feet long, and one of a bascule or lift span, which can be raised to let ships pass in to the upper part of the lake.

The point where the railroad crosses the Chagres River is known as Gamboa (a fruit like the quince). The bridge is built on a curve and spans an opening 1,300

Gamboa and feet wide. The channel span is a 200-foot Gamboa riveted truss, and it is connected with the Bridge. banks by 14 through-plate-girder spans, each 80 feet long. From the bridge one catches a glimpse of the northern entrance of Culebra Cut. A new townsite has been laid out at the northern end of the bridge. Pending the use of the relocated line between Gamboa 
and Paraiso, after the opening of the Canal, the trains leave the relocation here, back down across the dike that separates the excavation in Culebra Cut from the Chagres River, and run up the old line of the railway to Pedro Miguel. There is nothing of interest on the east side of Gulebra Gut between Gamboa and Paraiso, except the jungle and glimpses of its primitive life, because all the canal villages are along the old line of the railroad on the west side of the canal. A paragraph will tell about each one as the tourist catches glimpses of them while his train speeds on.

\section{The Culebra Cut Villages.}

(For facts on work in this section see page 88.)

Obispo means "bishop." There are two hills at this point, one of them higher than the other, called Haut Obispo, while the lower is called Bas Obispo. The Obispo

Bas Obispo. River flows into the Chagres at this point, and here in days before the railway was built was a hamlet of bush people. As explained at greater length in the section of this book on the canal, the Obispo Valley is utilized as the canal route to a point near the divide at Culebra. The hamlet was situated on the trail from Gorgona to Panama, was made a railroad station, and when the French began work was turned into a labor camp, with small shops. Excavation continued here on the sea-level plan until 1887, when the emplacement for locks was begun. Under the Americans the excavation was continued and Bas Obispo became a typical canal village. In 1908, it had 1,744 inhabitants; but its importance and size have dwindled rapidly since 1910 , when the excavation was practically completed at this point.

This village will always be associated in the minds of Canal workers with the greatest accident that has occurred on the canal. In December, 1908, the work

Bas Obispo in Culebra Cut at this point had reached a

Explosion. stage where it became necessary to dig out the side of the rock hill that rises above the canal on the west bank. To this end, 53 holes were drilled along the edge of the hill, and into them was packed 44,000 pounds of 45-per-cent dynamite. It was planned to set off this charge after the men had quit work at 5 o'clock on the evening of December 12. The last hole was being tamped at 11:10 o'clock on the morning of the 12th, when one of them exploded, setting off the others. The side of the hill 
was thrown forward into the canal, as had been planned, but beneath it were buried several men on their way home to lunch, while many others were struck by flying rocks. In all twenty-six people were killed, and a dozen were permanently maimed.

Situated upon a hill at Bas Obispo is the camp of the Marine Corps, Camp Elliott. It is a tribute to the spirit of this corps of the service, that the pretty Camp Elliott. little settlement was laid out, streets made, and some of the buildings erected by the men of the command. A battalion of marines is stationed here. In the course of three years this camp will be abandoned for one at the Pacific entrance to the canal.

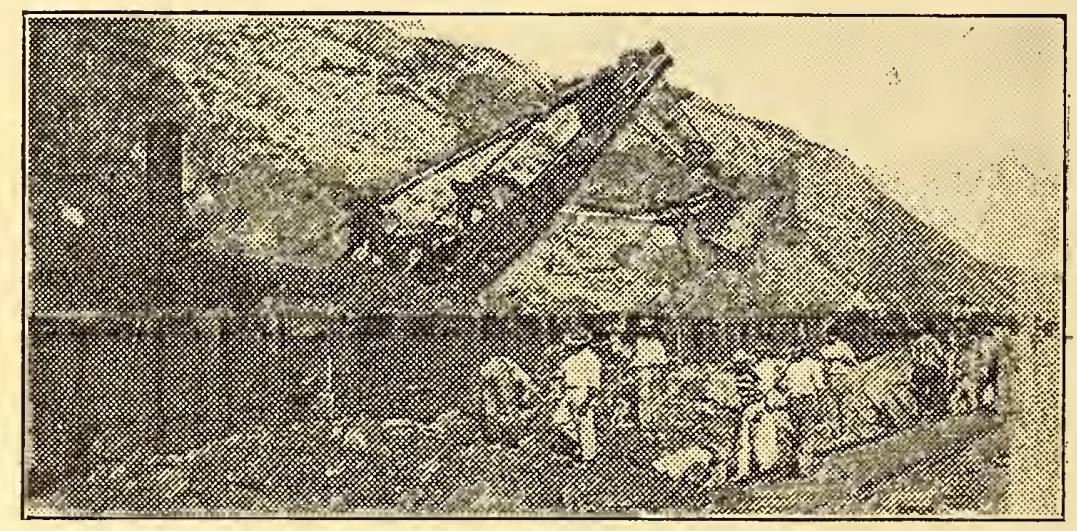

STEAM SHOVEL AT WORK IN CULEBRA CUT.

Every American in Panama delights in displaying his: knowledge of Spanish to the tourist. Invariably this knowledge is only sufficient to enable him to get Las Cascadas. into trouble with a coachman and require a policeman to extricate him; but he supposes that the tourist knows nothing of this, and is duly complacent. Your guide is of that type. Right along he has been telling you the English translation of the Spanish names and will continue to do so. Las Cascadas, for instance, means "the waterfalls" or "cascades." Here the Obispo River formerly tumbled over a precipice forty feet high on its way to the Chagres, and here still tumbles down the water collected by the diversion canal on the west side of Culebra Cut. This village dates from the French times, when it became the site of a labor camp. Under the Americans it continued as one of the centers of canal life. Here were established an engine-house, where forty locomotives 
tie up for the night to be cleaned out and made ready for their morrow's work, and an air-compressor plant to supply air to the drills in the north end of Gulebra Gut. It does not appear on the maps prior to 1880 and was not touched by the old trail that ran through Obispo on its way to Panama. In 1908, Las Cascadas had 2,425 inhabitants-957 whites, 1,424 blacks and 44 others.

In 1911 the labor camp near Las Cascadas was turned over to the United States Army for a temporary post, and quarters were hastily devised to accommodate

Camp Otis. a regiment of infantry hurried down from the States for no particular purpose that was apparent. It was named Camp E. S. Otis, in honor of the Major General of that name.

This village was originally called Emperador, and some American who knows even less Spanish than your guide, translated it Empire. It really means Em-

Empire. - peror. At this point, prior to the opening of the railroad, the trail from Gorgona to Panama crossed the line of the present canal and the headwaters of the Obispo River, and made off through the hills to join the Cruces trail to the city. Emperador was a stopping place for pack trains. Here the French made their first excavation in Culebra Cut, January 20, 1882, in the presence of a large assemblage of officials of the Canal Company and the State of Panama. The Bishop was present and blessed the work, and some champagne was opened to baptize it. The largest of the French villages was made here, shops were opened for the mounting and repair of equipment, and the place was made the headquarters of the Division Engineer. On the hill overlooking Culebra Cut are several houses erected by the French, now used by their successors on the job. The old French quarters were occupied by the Americans, and the machine shop was rebuilt. In this shop are now repaired all the steamshovels working on the canal and railroad. On top of the hill is the office of the Division Engineer, Lieut. Col. D. D. Gaillard, and the homes of the Resident Engineer, Mr. A. S. Zinn, and other canal officials. From the observation platform in the Division Office, may be obtained the best single view of Culebra Cut, showing how it winds like an elongated letter "S," following the contour of the ground in order to minimize the amount of excavation. A closer view may be obtained from the suspension bridge over the Cut, built 
for the purpose of carrying air and water mains to the east side of the trench, from the source of supply on the west side.

In Empire are all the features of a canal village, and it is taken as the type described elsewhere in this book (Page 42.)

Culebra means "the snake." It should have been called Emperador, because it is from this point that the dictatorship of the Canal Zone is wielded. It is the Culebra capital, the home of the Chairman and Chief Engineer, of the President of the Railroad, the Governor of the Canal Zone, the resident member of the Fortification Board, and of a dozen prominent officials, including the Assistant Chief Engineer, the Assistant to the Chief Engineer, two Division Engineers, the Electrical and Mechanical Engineer, the Chief Quartermaster, and all the designing engineers.

It was a little hamlet nestling among the hills near the summit of the divide when the Panama Railroad surveyors ran across it in 1850. In 1854, it was the terminus of the railroad and enjoyed a brief prosperity as the place where travelers stayed overnight and paid exorbitant prices for food and bed. Then it sank into insignificance until the French took up the Canal work, when it was made one of the centers for excavation in Culebra Cut. It was a typical Canal village with quarters for officials, labor barracks, storehouses, and Chinese stores. A force of $\mathbf{7 0 0}$ men was at work in the Canal at this point when the Americans took charge in May, 1904, and the village has therefore been a canal-worker's lodge since 1881.

In 1906, the Chief Engineer, John F. Stevens, moved his headquarters from Ancon to Culebra, and since then it has been the real center of the official life of the canal. On the top of the hill is the administration building, a long twostory barrack-like structure, and on the slope towards the canal were erected the quarters of officials and employes.

But since 1909 Culebra has gradually been sluffing away, for it is here that the largest of the celebrated slides is in movement. The west bank of the canal moves Culebra Slide towards the prism according as the toe of the slope is dug out at the bottom, and thus gradually there have disappeared in the Gut whole sections of the village, although never so rapidly but that the houses could be removed. In 1910, the work of digging from the top of 
this moving mass was begun, in order that by lightening it, the tendency to move forward of its $\mathrm{cwn}$ weight might be lessened. The village is gradually being rebuilt on the back slope of the hill, as the slide encroaches on the old site.

In 1908, the population of Culebra was 5,516, and it was then the largest of the canal villages. Now it does not number half that many people, and the first place in population has passed to Empire.

Returning now to the east side of the Canal and to the new main line of the railroad, the train stops at Paradise, for that is what Paraiso means. The

Paraiso original line of the Panama Railroad crossed the divide through the pass now used by the canal, and Paraiso was the first station beyond the summit. It was just a stopping place until the French took up the Canal work, when they made it one of their district headquarters, established a small machine shop there, and built quarters for officials and laborers. Later this was the site of one of the proposed high level locks.

The Americans enlarged the shop and added to it a shed for hostling locomotives. In 1908, at the time of the reorganization of the work by Colonel Goethals, Paraiso Shop was abandoned, and the trains ceased to stop at the village. (Just think of living where the trains don't stop.) The old shops are now used for the storage of machinery to be erected in the locks at Pedro Miguel and Miraflores.

Just before entering Paraiso the traveler gets a view of one of the prettiest interior valleys to be found in Panama.

Yet it is typical of a large number of similar

Prison Site basins among the hills', apparently completely enclosed, but really drained at some inconspicuous spot by a little creek. This is the site chosen for a penitentiary, if it is ever decided to erect a per manent prison on the Canal Zone. It is likely the matter will be left to the military government that almost surely will be established here after the Canal is opened. Paraiso had 2,622 inhabitants in 1908, the time when it was most populous.

There is a hill back of Paraiso, from the top of which one can see the tower in the ruins of Old Panama. It is said that from this hill the pirate Morgan caught

Hill of the his first glimpse of the city. Whether true Buccaneers or not, this is surely less important than interesting. 


\section{From "The Cut" to the Sea}

Pedro Miguel and Miraflores date from French Canal times, and bear respectively the names Saint Peter Michael, and Miraflores, a distinguished Spanish soldier. At Pedro

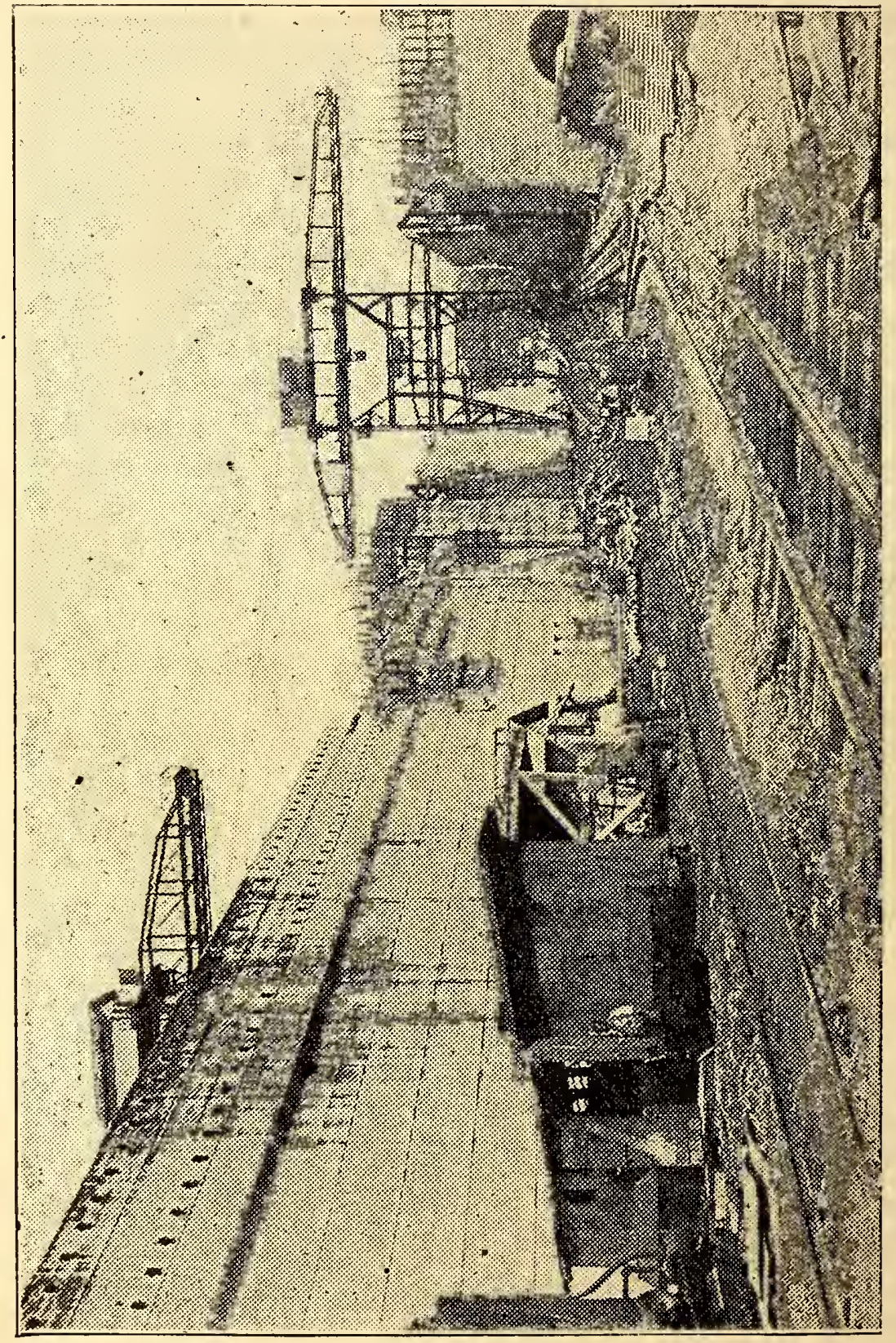

Pedro Miguel. Miguel the French had two dredges in operaMiraflores. tion, and there they had made emplacements for their locks. Under the American plan, it is the site of the first flight of locks that will lower ships from the level of Gatun Lake to that of the Pacific. Here 
is an engine house where as many as eighty locomotives tie up for the night. One of the most interesting sights on the canal is watching these locomotives leave the engine house for their work in the morning. The first one leaves about 6.30 o'clock, and the last is clear of the yards ten minutes later. Pedro Miguel had 1,623 population in 1908.

At Miraflores also the French had a small settlement, and this has been continued by the Americans, largely as a labor camp. Here are being constructed two of the locks required in completing the descent to the level of the Pacific, begun at Pedro Miguel. These locks will be the last finished and they are therefore the most interesting sight on the Canal work, because more kinds of work are in progress here than elsewhere.

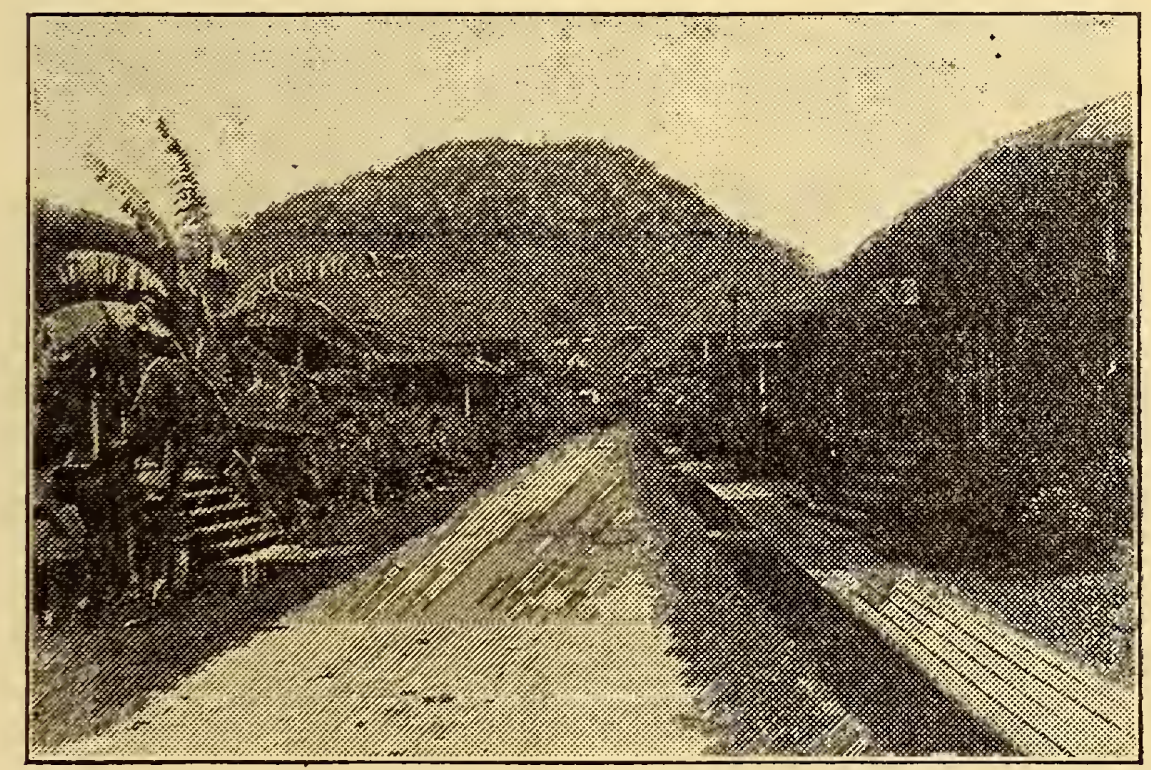

STREET IN CANAL ZONE VILLAGE-PEDRO MIGUEL.

When the lake is filled and ships are moving through the Canal, the Panama Railroad will be one of the prettiest in existence. For thirty miles the train will Miraflores skirt the borders of a lake; for nine miles Tunnel. more along the side of Culebra Cut, where Scenic the masts of ships will show up from the Railroad. canal and one will be unable to see the ships themselves from the car windows; for many miles through picturesque jungle; then it will look down upon the locks at Pedro Miguel, and run along the edge of another lake. Finally, and fitting climax, it will dash 
through a tunnel, and when it emerges one will see, straight ahead, Ancon Hill, the eminence that overlooks the Pacific entrance to the canal, while beneath his eyes will be the locks at Miraflores, and the sea-level channel stretching away to the ocean. This is something to think about as the train passes through the tunnel. The tunnel is 736 feet long, 15 feet wide, and $21 \frac{1}{4}$ feet high above the tops of the rails. It is lined with concrete. It was begun on July 1, 1907, and completed one year later.

This village is the headquarters of the Pacific Division, and the long low building on the knoll east of the railroad is the office of the Division Engineer, Mr. S.

Corozal. B. Williamson. Near it is the residence of the Assistant Division Engineer, Mr. J. M. G. Watt. It had 661 inhabitants in 1903 and has about a thousand now. The name means a clump of coroso palms. The village is mentioned before the founding of New Panama.

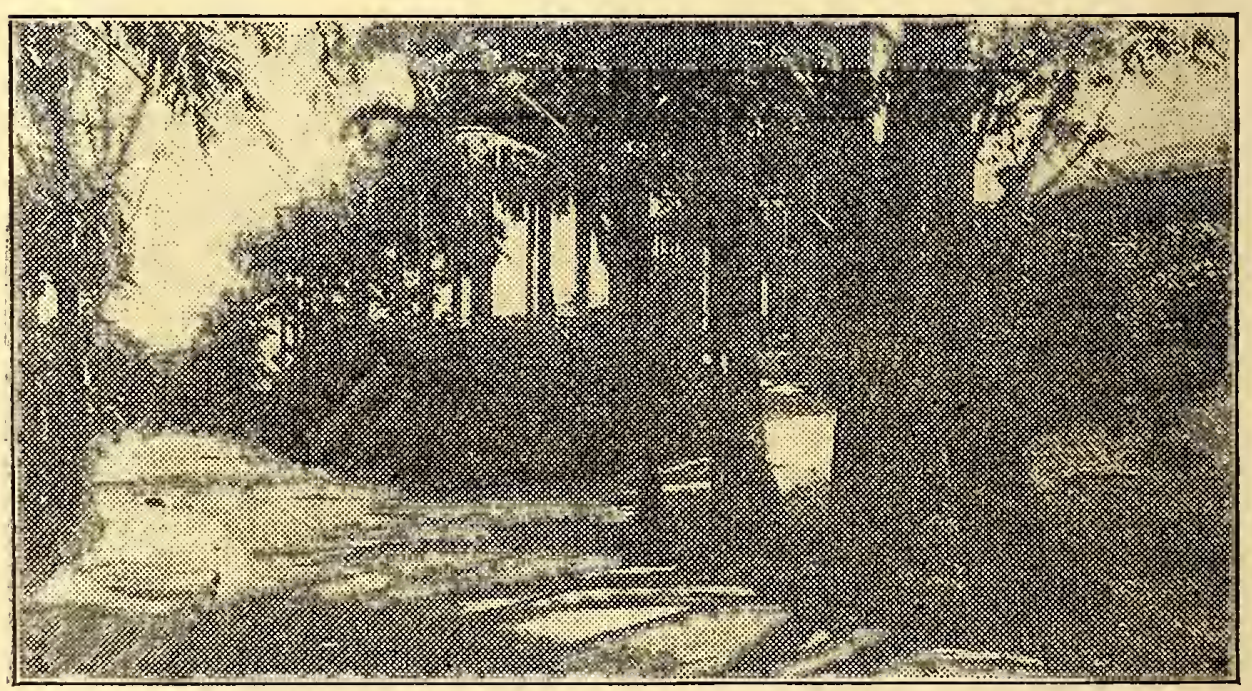

ENTRANCE TO ANCON HOSPITAL GROUNDS.

If your train happens to be the one that enters Panama at night, you will see, as it approaches the city, the lights of what appears to be a scattered village at Ancon. the base of a big hill. These are the lights of Ancon, the American settlement suburban to the city of Panama. It is named Ancon after the hill on whose terraced slope it is built, and the name means a roadstead or anchorage. It does not appear that there was any settlement here, according to old maps, until the 
place was chosen by the French Canal Company in 1881 as the site for its general hospital.

The terracing of the slope was then begun, and many of the buildings one sees there to day were constructed by the French and used by them all during their

Ancon twenty-three years of canal work. In the

Hospital. light of the time the hospital was well run, the main difference being in the knowledge of the mosquito theory as applied to malaria and yellow fever. When the Americans came to Panama in 1904 some of the beds in the wards were standing in cups of water to keep the ants from crawling upon the patients, and in this water mosquitoes of both the stegomyia and anopheles varieties were breeding.

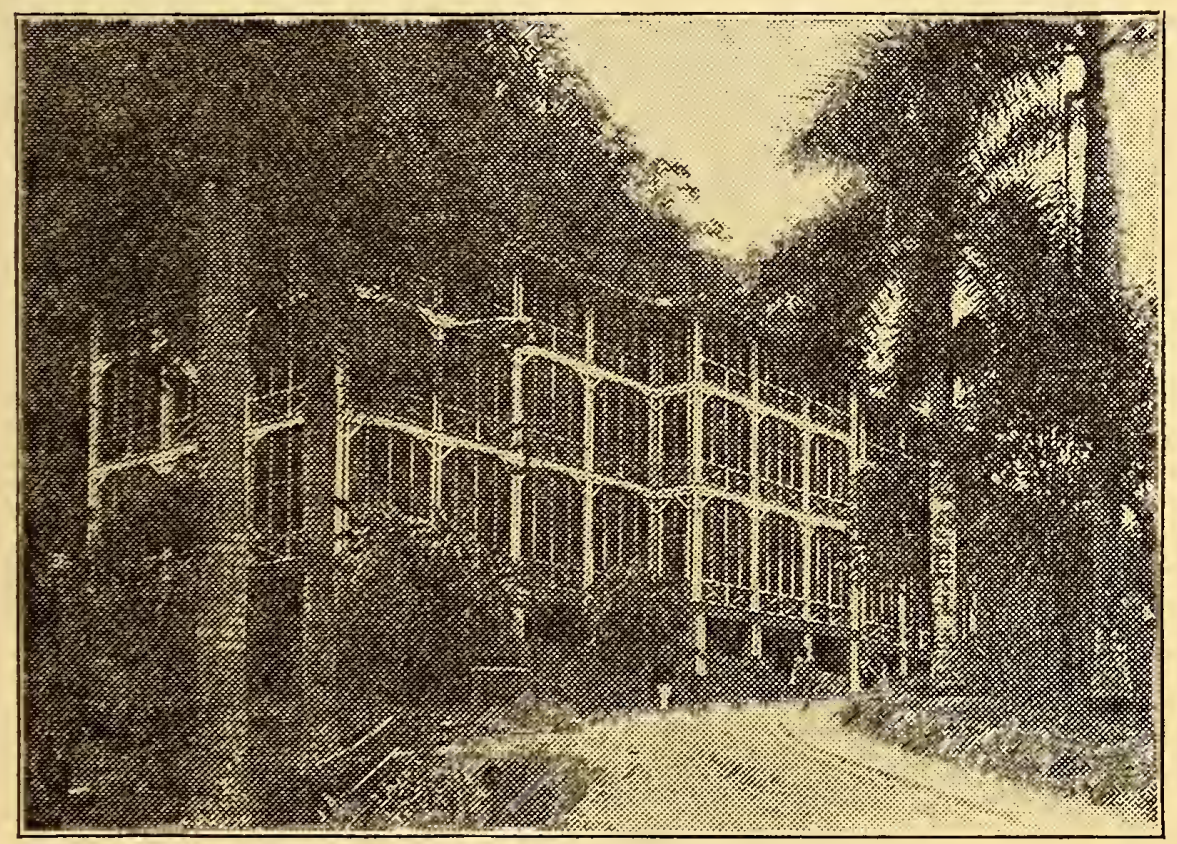

ANCON HOSPITAL GROUNDS

More about this hospital will be found in the chapter on Social Conditions and Forces, page 51. It is under the superintendence of Lieut. Col. Charles F. Mason of the Army Medical Corps, has a staff of 33 doctors and 90 nurses, and will accommodate easily 1,300 patients, and by crowding can be made to accomodate 700 more. (See pages $51,64,211$.)

To the tourist, the most interesting things about the hospital are the pretty grounds, the pajamaed patients sitting on the screened balconies or strolling about the 
grounds, and the many varieties of tropical plants. These plants have been catalogued by Colonel Mason, and most of the trees and shrubs are labeled. A list of them will be found on page $2: 1$.

The atmosphere of the hospital dominates Ancon, because, of course, that is the principal industry of the place.

Well, do you know, there are some well-bathed

Some Ancon Americans working in that hospital who have

People. never seen Gatun Locks except from the car windows, have an idea that Culebra Cut is the name of a choice piece of meat sold only to high officials, and believe that the United States is constructing a sea-level canal in Panama!

The Administration Building, on one of the knolls at the foot of the hill, is the only good building erected by the

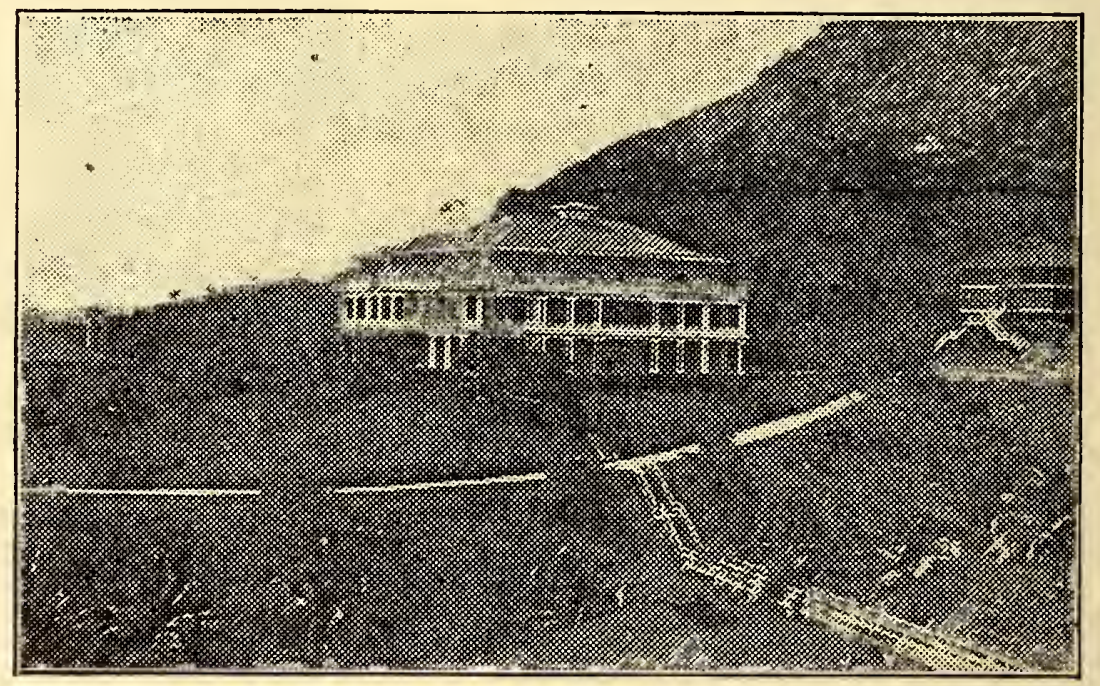

ADMINISTKATION BUILDING-ANCON.

Americans in Panama. It is of concrete block, Administra- and was originally designed to be the residence tion Build- of the Governor of the Canal Zone. This ing. plan was abandoned in 1906 on account of the cost of maintaining such an establishment.

Here are the administrative offices of the Department of Sanitation, the Department of Givil Administration, and the Secretary of the Commission, the publication office of The Canal Record and the Oficial Handbook. The view from the upper balcony of this building is probably the best that can be ob- 
tained of the Bay of Panama, the city, and the near by hills without a toilsome climb up Ancon Hill itself.

Supreme

The office of the Supreme Court is in Court. Ancon, immediately back of the Post Office

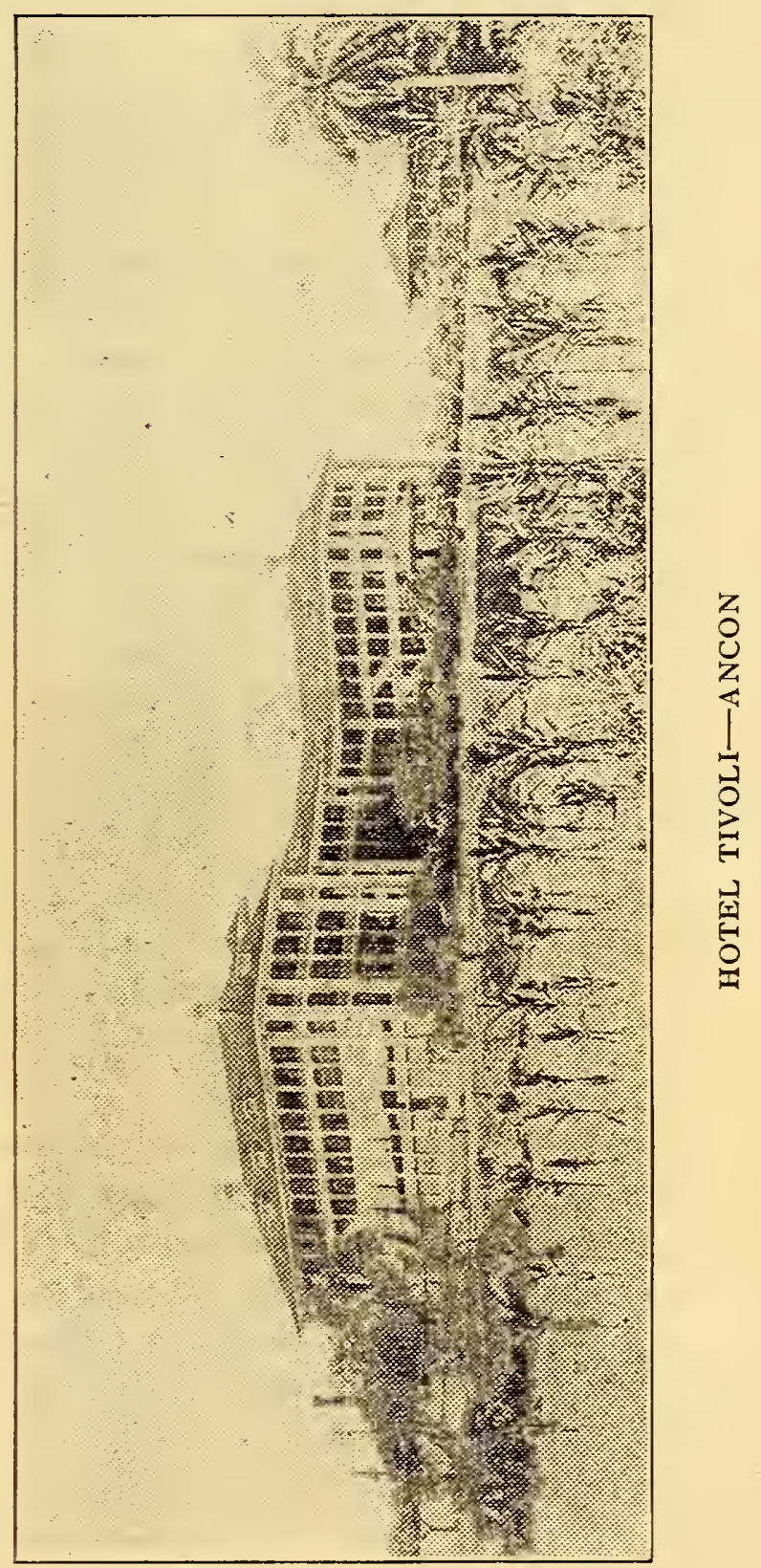

The Hotel Tivoli was built for the threefold purpose of furnishing quarters to employes who had arrived on the Isthmus and had no quarters assigned to Hotel Tivoli. them, for the use of persons whose business with the canal administration forced them to come to the Isthmus, and the recreation of employes, whose 
chief dissipation is a trip to the city about once a fortnight. To further this latter end, a dance hall containing 3,200 square feet of space was constructed, and an organization of employes known as the Tivoli Club is given the privilege of holding a dance here the second and fourth Saturdays of each month. The building was begun in August, 1905, and opened to the public on January 1, 1907, although a part of it was used in November, 1906, for the entertainment of President Roosevelt, on the occasion of his visit to the Isthmus.

It is situated on a knoll named after the Tivoli Hill of Rome, and overlooks the eity of Panama and part of the bay. It is built in three sides of a rectangle, the main part being the base, and the two wings the sides. The open court in front is occupied by a carriage-way and flower-bed. In 1912 an addition was made, which increased the sleeping accommodations from 180 guest-rooms to 220 , and the dining-room accommodations from 400 to 700 persons. The building is 314 feet long, wings 156 feet deep, and courtyard in front 193 feet across and 91 feet deep. This hotel has lately become more for transients than for people resident on the Isthmus, because the tourist trade has increased so rapidly in the past two years. Yet it is still the place where bachelors from the canal villages come to get a different kind of meal from that served in the messes, where concerts are given by the official band once each month to balconies crowded with canal workers, and where the best dances on the Isthmus are held.

Ancon Hill is 664 feet high above mean tide. After one climbs half way to the top it seems like six thousand feet, and by the time he has reached the

Ancon Hill. summit it feels like six million. The climb is worth while, however. Start about daybreak, spend half an hour on the ascent, an hour on the top, and half an hour on the descent, and you will be home in time for breakfast, and none the worse for the trip. It is a rapid ascent that tires one. From the top there stretches such a view as can not be equaled on the Isthmus, and $I$ am told that it can not be surpassed anywhere. Out to sea is the waveless bay, dotted with islands; farther away are Taboga and its sister peaks rising out of the water, with their little settlements at the base of the hills; and towards the east the long line of the coast stretches away to Darien. Behind are the hills, at one's feet the city of Panama and the 
entrance to the canal, and northward the eye can follow the valley of the Rio Grande to the point where the line of the canal is lost in the foothills of the cordillera. This view so charmed the first American Canal builders that there was talk of building the village of Ancon on top of the hill and providing moving stairs for the ascent.

Rock for the concrete at Miraflores and Pedro Miguel Locks is quarried from the side of Ancon Hill, where a series of benches or inclines has been excavated Ancon Quarry. from 180 to 375 feet above sea level. The rock is loosened by dynamite, and then excavated by steam-shovel, and loaded upon cars which run down to the crusher-plant which is situated below the 180 -foot level. There the cars dump into a hopper, from which the large rock passes by gravity to a crusher capable of taking a piece of rock 36 inches in cube, and the smaller rock passes to four secondary crushers, which also crush the product of the large crusher. From the secondary crushers the rock passes to storage bins, whence it is loaded by gravity upon cars, which convey it to the locks.

The name Balboa, as applied to the village at the Pacific entrance to the Canal, dates from April 30, 1909, when, at the instance of the Peruvian Minister to

Balboa. Panama, the Hon. Alfonso Pezet, Colonel Goethals issued a circular directing that the old village of La Boca be called Balboa.

La Boca (the mouth) was the name applied to the hamlet which grew up at the mouth of the Rio Grande, where there was a crossing of the old trail that runs from Panama to the villages west of that city. The French, as the Americans have done, used the valley of the Rio Grande as the southern end of their canal line, and in 1881 they began to erect shops here at which their dredges from Scotland and Belgium (all but one erected on the isthmus) could be set up. The shops were well equipped for the time and the work they had to do. Naturally a village sprang up, composed of the shop and dredgemen.

On the side of Ancon Hill overlooking the Pacific entrance, Jules Dingler, Director General of the canal work, erected a spacious house in 1885 , but soon

La Folie after his wife and two children arrived here

Dingler. they died from yellow fever, before the house was ready for occupancy, so he did not live there, returning to France in June, 1885. It was a big frame 
structure that is said to have cost $\$ 125,000$. It was used later as a hospital for Colombian troops, and from 1904 to 1910 was used by the Americans as a quarantine station. In February, 1910, it was sold for $\$ 525$, on condition that the buyer would remove it. This was to make way for Ancon Quarry. The house was called "Dingler's Folly."

In 1899 the terminal pier of the Panama Railroad was opened to traffic, and since then the village has been both

a canal and railway settlement. The Ameri-

Present and can Canal work required the enlargement of Future of Bal- the marine shops and this was begun in 1905

boa. for the purpose of rebuilding some of the old French dredges. The dredging and machineshop work are now carried on under the direction of Mr. W. G. Comber, resident engineer, and James Macfarlane, superintendent of dredging.

At this point there is now in progress the erection of terminal docks, and the construction of a dry dock and coal supply station. In the course of 1913 construction of the buildings for the Army and Navy headquarters will probably be begun. While most of the canal villages are looking backward on their glory, Balboa is looking forward to a larger population, more work, and greater importance than it has yet known.

\section{A Canal-Builders' Village.}

At the headwaters of the Rio Camacho, there is a broad basin between the surrounding hills, half a mile in width and several miles long, but gradually becoming narrow at either end. At the broadest part of this basin is situated Empire, most of its houses on the low flat ground, but a few built on the sides of the hills. It is taken as the typical Canal village because here are all the features of any of the settlements, many that are not included in some. A road runs across the valley and climbs the hills on either side, and at right angles to it runs another highway connecting the village with Culebra on the south and Las Cascadas on the north. Along these roads the village has built up, although there are a few short side streets. There are four distinct sections of this village - that where the white Americans live; that occupied by local merchants and those natives, Chinese and negroes, not at work on the Canal; the negro settlement; and the European labor camp. 
The best part of the village the Americans have naturally monopolized for themselves. Their homes and bachelor quarters are built along the principal streets, and there also are the public buildings. The homes of the betterpaid officials are really handsome structures, all of wood, two stories high, and so openly constructed that the air can blow through and keep them cool.

A typical house has a veranda on two sides, two big airy rooms in front, an open room at the back with only mosquito screen between it and outdoors, used as a diningroom, alongside it on one side a kitchen, and on the other a servant's sleeping-room. Upstairs are bed-rooms, bath, and toilet. The house will comfortably accommodate four or five persons, and the occupants usually number a man and his wife and a child or two. One who receives a salary of $\$ 400$ a month or more is assigned such a house as this or a better one. Another typical house is a one-story bungalow, with a veranda across the front, two living-rooms, a bed-room, a dining-room, kitchen, and bath and toilet. All the rooms are tiny. They are built for young married people presumably; but more frequently than not they are occupied by a man and his wife and four or five children, because, somehow or other, poor people breed most. One who draws a salary or wage of $\$ 200$ or less lives in such a house, or perhaps he has one of the four apartments in the fourfamily houses; if so, his accommodations are about the same as those in the cottages. All the houses, large and small, are of this type, unless it happens that there are left some of the three-room cottages provided by the French for their employes, and irreverently called by the Americans, "dog houses."

There are two features of the housing that are rather unique-the broad verandas which are used almost entirely as sitting-rooms (the families practically live there), and the lack of cellars. The houses are built on piers of concrete and sticks, and if one lives on a hillside there is left a good place under the house for the children to play. Altogether the housing effect is good, and the accomodations excellent. Electric lights are furnished. 
The commissary is situated in the center of the American village - a long low building, neatly divided into departments; for this is a general store of the

Commissary type known as "country store" in the United and Other States, only better. Here every morning meet Stores. the housewives of the village to select the food for the day. Here all day long people straggle in to buy food, clothing, and toilet articles, or perhaps to invest in some of the pretty china exposed for sale. The prices are lower than in the States, generally speaking, and the service is just as prompt. You must carry the goods home. 'Every morning, however, the order boy calls at the house and takes your order for the day, if you choose to buy that way. This order is delivered to the house before noon. But it is better to go down to the store, because one meets others there, and if there is any news floating around it is there that one hears it.

The other stores are run principally by Chinese. They are situated outside the American village, and are patronized chiefly by the native, non-Canal worker element, although the Canal worker often finds there articles that are not carried in the commissary. One of these stores is run by East Indians, and is a fancy-goods shop where there are sold very pretty articles of oriental make, such as fans, silks, brasses, and fancy crockery.

The Commission clubhouse, conducted by a secretary of the Y. M. G. A., is the chief center of the village life. This building is two stories high, roomy, Social Centers. and cool. In the center is a broad lobby, on one side of this a pool and billiard room, on the other a reading room with magazines and books, behind it a quick-lunch counter. In the annex at the back are barber shop, locker and toilet rooms, baths, bowling alleys, and a pavilion in which soft drinks and ice-cream are served. Upstairs is the assembly hall, with a stage at one end, and here are given moving-picture and other shows, and are held the bi-weekly dances. Also on the second floor are retiring-rooms for women, and a game-room, where mighty battles are fought by bishops, knights, and pawns, to decide the old foolish question as to which king shall live.

A building used as a church and lodge hall stands a little distance away from the main street, and there meet the religious organizations that have no meeting places of 
their own; and upstairs, over the chapel, such secret societies as are established here. Among these are the Kangaroos, Odd Fellows, Pythians, Red Men, Rebekahites, Knights of Columbus, and Masons.

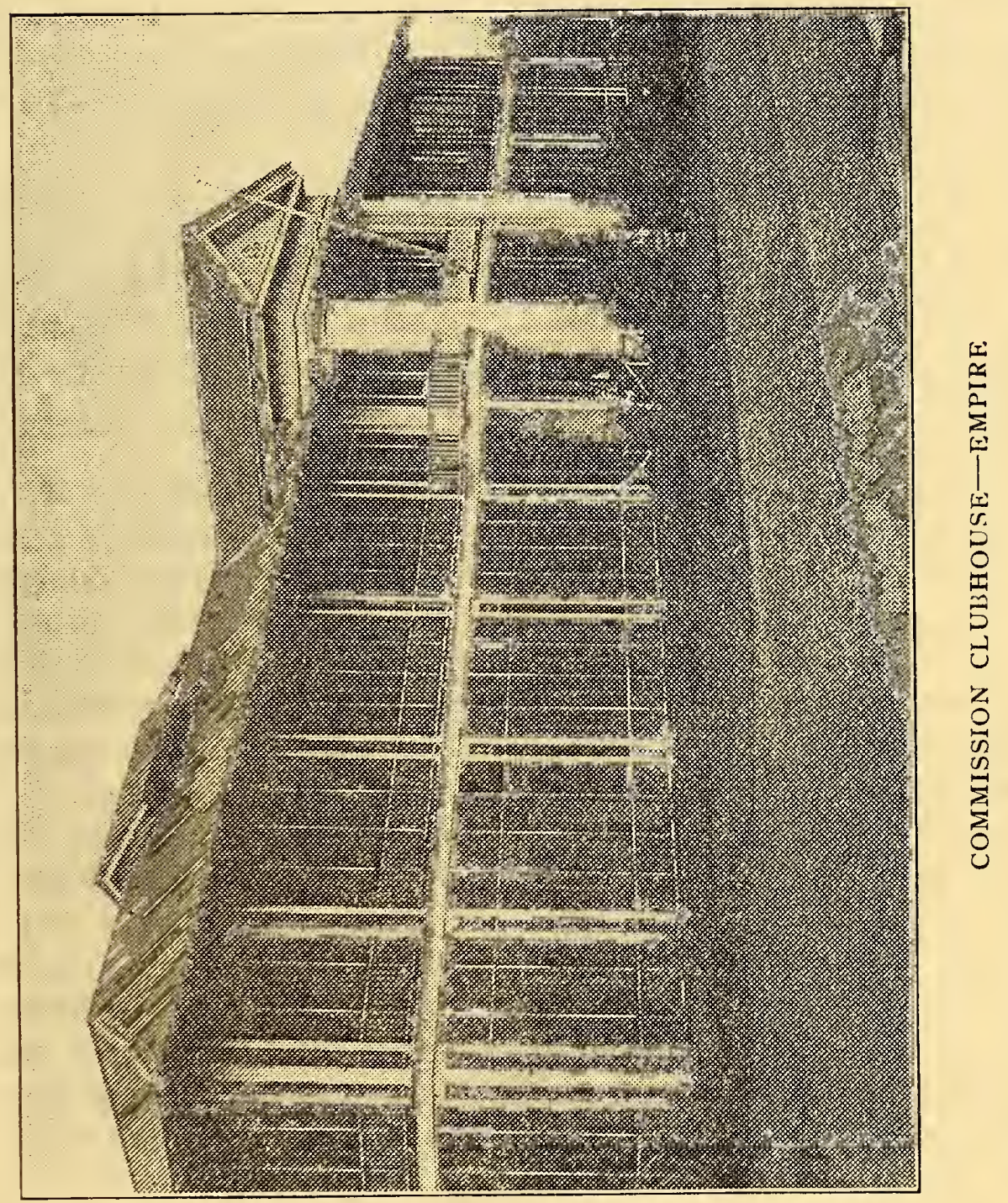

This is really not a hotel but a mess hall, because one can not rent a rocm here. It is a long one-story building, with a broad veranda (on which men who

Commission have their coats on may eat), a big room filled Hotel. with tables (where eat the coated and coatless), and a kitchen where the food is prepared. An employe pays 30 cents a meal, and kicks; a tourist pays 50 cents, and says it is excellent. Both are right. The meals are much alike every day, and that is why the regular boarder complains; but they are the biggest thirty- 
cents' worth of food imaginable. Yet they actually cost only 30 cents, because the hotels are self-sustaining. There are two features that wear on the nerves-the heaped up bottles of catsup, chowchow, jelly, pickles, mustard, chutney, mayonnaise, and other delicacies and relishes in the center of the table; and the clatter of dishes that always characterizes a "hash house." But this must be expected in a place where a wholesome meal with an abundance of food costs only thirty cents.

The Episcopalians have a church of their own, and so have the Roman Catholics. They are very act-

Churches. ive congregations, with something doing three nights a week. The Empire Union Church, the Baptists and other sects meet in the public church and lodge hall, and there are two churches outside the American settlement for negroes,

The baseball park occupies a lot near the center of the village; and here, while the players in the States are tending bar or resting during the winter months,

Sports. the Canal Zone nines contend every Sunday for the championship. There are good games, and no end of enthusiasm. At one end of the village are the tennis courts, and here, too, good games are played, with regular tournament series during the dry season.

At noon and at night the trains pass through on their trip across the continent. Scores of men gather here to watch the pretty faces that are poked out of

The Train. the car windows. Some people get on the trains and others get off, there is an exchange of greetings all around, and then they all go home, in pairs or groups, talking about one another, or discussing the latest news of the Canal Zone and the world, as brought to them by the newspapers.

This typical village comprehends all kinds of workingmen. The engineering and administrative office for the excavation of Culebra $\mathrm{Cut}$ is on the hill on the

The Workers. east, at the foot are the shops, at the other end of the village on the toe of the opposing hill are the offices of the Comptroller and of Disbursements. Here live steamshovel, transportation, and powder foremen-laborers, clerks, officials, engineers, and draftsmen-all classes of Canal workers. All told they number quite five thousand people, making the Canal Zone metropolis. 
The ordinary economic bar between the laborer and the more advanced economic classes is added to on the Isthmus by the fact that the laborer is either alien European in language and nation, or alien in race. It Laborers. is natural, therefore, that there is little in common between even the European laborer and the white American. The Spaniard lives in a labor camp apart from the remainder of the village, and has his mess nearby, (where he is served food in a rough fashion for 40 cents for 3 meals), and has his interests in the camp and in the cantinas run by men of his nation. The Government has not been eminently successful in feeding the Spanish laborer, because he does not like the American way of cooking, and anyway prefers the atmosphere of the cantina, where he can have his wine and can sit long over his dinner, discussing with his fellows questions of common interest. There are only 200 Spanish-labor families on the Isthmus living in the small quarters provided for them by the Government. There are probably twice as many more living in privately rented quarters in the various villages and in Panama and Colon. More about the Spanish laborer will be found in the chapter on Social Conditions and Forces, which follows this.

The insurmountable bar of race is between the negro and the other canal workers. He lives alone with his kind and since he is numerically four times as West Indian strong as the white men on the force, he is Negroes. self-sufficient. His labor camp consists of barracks where from 40 to 80 men are housed, a kitchen where he is served three meals for 27 cents, and a clubhouse run by a negro society, church, or church guild. He is distinctly sociable, drinks little, and sings much, and appears in general to enjoy his higher economic status. It is proposed to move all the negroes back to the West Indies when the time for turning the Canal Zone into a military reservation comes. This will be hard on the West Indian planter, because the negro has learned in the Canal Zone that the wage paid in Barbados and Jamaica is about fifty per cent too low. More about the negro laborer will be found in the chapter on Social Conditions and Forces, which follows this. 


\title{
Social Conditions and Forces.
}

\author{
The best analysis of social conditions in the Canal Zone \\ yet made is contained in the book on Panama, in "Porter's \\ Progress of the Nations"' series (George Routledge and Sons, \\ Publishers, London, 1912); and, because it is the best, it is \\ quoted here:
}

Social institutions and conditions in the Canal Zone can be understood only in view of the nature of their being and the varied class of people that influence them. It is commonly said that the villages along the Canal are well regulated American towns. This is true only in appearance.

The effort of the Government was to transplant the life of American villages to the Canal Zone, but in the truest sense this can not be done, because such life is the result of slow growth and can not be picked up and transplanted, any more than an apple-tree can be made to grow in the torrid zone. Every Canal village has churches, schools, meeting halls, libraries, and social organizations; but they are like similar institutions in the United States in form only. Even the people themselves are different.

Taking as an instance only the white American population, these differences are deeply marked. In a village such as Culebra, the capital of the Canal Zone, there are people from the South, New England, North, and West, of the United States. The analysis of the representatives of these four distinct social sections, made by James Bryce twenty years ago, is still correct in all important respects. Any generalization must fail of the truth, but it is indicative of the diverse background of the people from these sections to say that the New England man is a penurious Puritan tainted with intellectual snobbery, the northern man has a distinct commerical bent, the western man is a trader of strong progressive political thought, and the southern man not entirely free from the belief that the civil war of 1860-65 is still being waged, and delightfully convinced that his people have a monopoly of refinement in America. These people meet one another daily, and learn more in a month, from a social standpoint, than they could have learned in years in their home communities.

In the ordinary American community it is seldom that the son of a merchant fraternizes with the son of a mechanic; and in cities of 25,000 inhabitants or over, lines are usually drawn between the members of various churches, not because of religious convictions, but because the church is a social center. Then there are differences of education, culture, birth, and profession, that tend to make people in long-established communities form little coteries, with a consequent narrowing of both knowledge and sympathy. In the Canal Zone there are not enough people of any one industrial class, with common church, professional, and cultural interests, to form these little cliques for social stagnation, and the result is a broadening of social and intellectual horizon that keeps most of them in a fever of excitement.

Nor should one lose sight of the fact that practically everyone on the Canal work is on a higher economic plane than ever before This has resulted in a forcing of cultural and social standards, 
pathetically evident in the efforts of some women to emulate others, and of a few to emphasize the differences between themselves and their social sisters.

It has been said that social institutions in the Canal Zone are like similar ones in the United States in form only. Canal Zone churches, clubhouses, and meeting halls are furnished by the Government. The benevolent despotism, of which Col. Geo. W. Goethals is head, has been too kind for the social good of the community, although its policy has been justified in the smooth working of the Canal building machine.

There is no participation in politics. The laws are made in Washington and Culebra, without question as to the wishes of the people, and there is a consequent loss of social development. If one wishes to know what to do or how to do it, he consults The Canal Record, the weekly bulletin of the despotism, and finds there the law as the despot has issued it. And the people like it. After the policital strife of every American city, it is pleasant to live where all is quiet. One who has experienced both kinds of life knows why the "chosen people" longed to turn their backs on Moses and return to the flesh pots of Egypt.

Here there are no elections to determine whether a new school building shall be erected, or certain streets paved, or a municipal water-system installed; and therefore little thought of municipal government or improvement. Here are no mass-meetings to arouse enthusiasm for a new church building, an orphan asylum, or other social palliative. The Government has decided, or will decide. I :say this Government has been too kind, because no matter how pleasant it is to have others do one's thinking the effect of five years or more of benevolent despotism in the Canal Zone, has convinced me thoroughly of the educative value of a democratic form of Government.

There are many other similar influences, but those cited are the most important in coloring the social conditions and institutions of the Canal makers. It is patent that they are fundamental, and one of their most frequent results is that grown-up people of convictions long settled find themselves, after a few months of the Canal builder's life, drifting from their conventional moorings.

CHURCH WORK.

Under the conditions outlined it will be readily understood how formal religion has suffered loss by the migration to the Canal Zone -of people who were regular "church-goers" in the United States The sudden broadening of mental and spiritual horizon, consequent upon the abrupt change from a highly formalized mode of living to an entirely different atmosphere, has crystallized in many people an impulse, felt everywhere in the United States, towards a rejection of formal religion. Even Roman Catholics in the Canal Zone are indifferent to a greater degree than in the United States.

Another influence in this rejection of formalism is the breaking up of the home routine. In the United States the average middleclass family eats breakfast at 8 o'clock on Sunday morning, adorns itself in holiday clothing at 9 o'clock, and at 10 o'clock goes to church. The church-going is as much a part of the routine as the breakfast. At church one meets his friends, listens to a sermon that is often good and seldom displeasing, takes part in music that is at least as

MR 22928-4 
high-class as the average taste of the congregation, and on the whole is pleasantly diverted. In Canal Zone villages the sermons are poor and the music not so good as the taste of the listeners.

If each congregation of Canal workers had a feeling that it was building up a permanent organization for social advancement; had before it some tangible ambition, such as building a church and paying for it; or if it could feel in some way that it was being persecuted, the handicaps of environment and unattractive services might be neutralized. But there is no persecution, no tangible goal, no feeling of permanency, with the result that the attitude of the average Canal worker towards formal religion is that of indifference.

In the scope of this chapter it is impossible to give more than a suggestion of the admirable work various religious organizations are doing under these adverse conditions.

The longest-established church in the territory of the Canal Zone is the Roman Catholic, which draws no color line, and embraces in its membership, Americans, Panamans, European laborers, and negroes. As an organization its spiritual power over the Europeans and Panamans has been weakened by the fact that it has uniformly stood, both in Spain and Spanish-America, for reaction, and in the minds of the mass, which can not draw the line between church government and the spiritual church, it is identified with political and economic oppression. With this handicap it yet draws to its services men and women of all classes, and every mass on Sunday is said in the presence of scores of people. There are six churches in the Canal Zone, and the pastors of three of them (a Spanish, a French, and an American priest) are men of distinct intellectual and spiritual power.

The second-oldest church organization is the Protestant Episcopal, which opened Christ Church in Colon in 1865. In 1883 when the West Indian negroes came to the Isthmus in large numbers to work for the French Canal Company, the work was placed under the jurisdiction of the Anglican Church, to revert in 1907 to the Protestant Episcopal Church of the United States. Its work among the negroes is of more importance than that among the whites, because the former are more in need of spiritual guidance. There are thirteen congregations of negroes and five of whites.

The change in surroundings and the rise in the economic scale experienced by the West Indian negroes, by reason of their migration to the Canal Zone, has had the opposite effect on them from what it has had on the Americans; and they have become more diligent in their church-going. This assertion is made on the authority of the Rev. Henry Bryan, one time archdeacon of the Canal Zone and Panama, who quotes the undivided opinion of the Anglican clergy of several West Indian islands, scores of whom he questioned on this subject. The most evident reasons are, first, that the negroes on the Canal Zone have their own churches, and there is none of the feeling that they are inferior to anyone in the church work; second, the Governinent of the Canal Zone has insisted upon marriage as a prerequisite to cohabitation, and there is a distinct increase in the self-respect of the negroes who are living together under the formal sanction of religion and law.

Among the sectarian or evangelical churches the Wesleyan is the most potent. It was established on the Isthmus in 1882 to care for negro laborers of that sect, and now has two ministers and sixteen 
lay preachers in the Isthmian mission. The Methodist Episcopal Church maintains a mission and school in Panama city, and works chiefly among the white Americans, although its missionary society has begun to proselytize among the Panamans. The Baptist Church works among both negroes and whites, and one of its missionaries; the Rev. S. M. Loveridge of Culebra, is accorded by the Canal workers the distinction of being the most powerful spiritual influence among the 30,000 negro workmen. A nonsectarian organization. known as the Union Church was organized by several Canal employes in 1907. and now conducts services in the Government chapels in five different Canal villages. Among other organizations doing spiritual work along definite lines are the Christian Science, Seventh Day Adventist, "The Remnant of Israel" (Hebrew), and the Chinese. temples at Panama and Colon.

Church work was authorized by the Isthmian Canal Commission on October 4, 1905, as one of the means of stabilizing the working force, and promoting social order. Of forty church buildings in the Canal Zone in 1911, seven were Roman Catholic, thirteen Episcopal, seven Baptist, two Wesleyan, and eight undenominational. All but two of the buildings are on land set aside by the Government, and twenty-six are owned by it. Fifteen chaplains are maintained by: the Government, of whom four are Episcopalians, four Baptist, three Roman Catholic, one Wesleyan, and one Presbyterian.

Although it is carrying on a more vital class of work than any of the churches, the Salvation Army is classed with them, because of the fact that it also conducts religious services. The work dates from May 19, 1904, and is confined almost entirely to West Indian. negroes. A rest house, where free lodging and meals may be procured by the needy, is maintained in Colon in a building erected by the Canal authorities, and outposts are maintained for welfare work in Panama City, and the Canal villages of Gatun, Gorgona, and Empire. The Army emphasizes the fact that it is assisting the laborers by lending them meals and a place to sleep, and in consequence at least fifty per cent of the people who accept its aid do not leave the Isthmus before paying the entire indebtedness, while many more make some payment. Services of the characteristic Salvation Army kind are held at street corners, and in the various posts, and they are

$\underset{*}{*}$ well attended.

\section{THE SICK AND INJURED.}

In every Canal village there is a public dispensary presided over by one or more physicians, and equipped with an emergency operating-room and a good drug-store. The physicians have regular office hours for making calls on patients confined to their homes. Only the simplest cases are treated at the home of the patient, the aim being to send everyone who is likely to become very ill to one of the two main hospitals, situated at Ancon (Panama), and Colon. Emergency cases are treated in the dispensaries only to the extent of giving first aid, and the patient is then sent to one of the main hospitals.

The hospital at Ancon can accommodate 2,000 patients, though the wards are rated for 1,500 only, and the staff is organized for that: number of patients. At Colon the hospital is arranged for 200 . patients, but in emergency can accomodate half again that number. These hospitals are modern in equipment both for medical and surgi- 
cal cases, and at Ancon there is a large laboratory in which tropical diseases are investigated under the distinguished pathologist, Dr. S. T. Darling. On the island of Taboga in Panama Bay is a con. valescent hospital, where a few of the patients spend the week immediately following their discharge from the hospital.

This system of free medical treatment has been in effect seven years. With a carefully selected class of employes, and a population where the average age is not above 35 years, the results, viewed from a statistical point, would be misleading. From a social standpoint they are probably typical. There has been no noticeable development of the "chronic," as might be expected where drugs are dispensed without cost. The physicians are not tempted to encourage illness, and the people are not encouraged in it. In consequence there is very little medicine dispensed, outside of quinine for malaria and salts for constipation.

Taking away the incentive of private fortune has had no apparent effect on the physicans employed by the Government. These men are selected after competitive examination, and as a class are above the average of their profession in the United States. They are paid salaries varying from $\$ 1,500$ to $\$ 7,000$ a year, the average being $\$ 2,800$ a year. They have a medical society which holds monthly meetings, and they have maintained an esprit $d u$ corps no less remarkable than that of the remainder of the Canal force.

The investigations of malaria which have recently won for Dr. W. E. Deeks and Dr. W. McC. James election to various English and American societies of specialists were conducted in connection with regular practice among the patients at Ancon Hospital. Others of the medical profession are doing just as serious work in connection with their other duties; and this spirit of professional enthusiasm is characteristic of the whole staff.

Many of them who entered the Canal service merely as a stepping stone to more lucrative practice, are now frank to say that they would remain in the Government medical service at purely nominal salary, rather than to take up the occupation of a private-adventure physician in general practice.

\section{SCHOOLS.}

Two schools for primary instruction are maintained in the Canal Zone by Spanish laborers, but except for these the schools are maintained by the Government. There are two distinct systemsone for colored children and one for white children.

Teachers in the schools for white children are recruited in the United States, and the requirements are fully as severe as those in the average small city in the United States, including professional training and actual teaching experience. There are ten primary schools, and one secondary or high school.

Teachers for the colored schools are recruited with the assistance of the Government of Jamaica, and are chiefly Jamaican negroes who have had professional training in that island. There are sixteen schools for colored children. In addition to the primary branches an effort is made to teach the rudiments of farming, to the negro 
children, on the assumption that they may remain in the Canal Zone where the opportunities for small farming are good.

A statement of the school attendance in 1911 follows:

\begin{tabular}{|c|c|c|c|}
\hline Sex. & $\begin{array}{l}\text { Enrolled } \\
\text { White. }\end{array}$ & $\begin{array}{l}\text { Enrolled } \\
\text { Negro. }\end{array}$ & $\begin{array}{l}\text { Total } \\
\text { Enrolled. }\end{array}$ \\
\hline 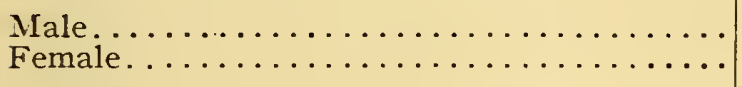 & $\begin{array}{l}682 \\
728\end{array}$ & $\begin{array}{l}775 \\
793\end{array}$ & $\begin{array}{l}1,457 \\
1,521\end{array}$ \\
\hline Total... & 1,410 & 1,568 & 2,978 \\
\hline
\end{tabular}

The work is directed by a Superintendent, assisted by two inspectors, 43 white teachers for the white schools, and 24 for the colored schools. Education is not compulsory. Text books are supplied free of cost.

\section{PENAL SYSTEM.}

The educative idea does not enter into the penal system of the Canal Zone, the imprisonment of offenders being entirely on the assumption that they owe a debt to the community. Persons convicted of misdemeanors are imprisoned in local jails at Ancon, Emire, Gorgona, and Cristobal, and are made to do work about the jails and police stations, and sometimes on the municipal roads and streets. Persons convicted of crimes are imprisoned at the penitentiary in Culebra, and the majority of the men are set at work on the Canal Zone highways. Their services are valued at 10 cents an hour. In the year 1910, when the. Canal Zone population was largest (approximately 65,000) there were 6,407 males and $477 \mathrm{fe}$ males placed under arrest, and 80 per cent of these were convicted, the majority of misdemeanors, for which the sentence was a fine or imprisonment for not more than 90 days. One hundred and thirtyseven felony convicts began sentence at the penitentiary during that year. There were sixteen homicides, in which cases there were five convictions, eight acquittals, one dismissal, one sent to the insane asylum, three awaiting trial. Capital punishment is by hanging, and is inflicted only for premeditated murder. The policing of the Canal Zone, a territory of four hundred square miles inhabited by 65,000 people, is done thoroughly by a force consisting of one hundred and forty-six white and one hundred and eleven negro policemen, directed by a chief and assistant chief of police.

\section{MISCELLANEOUS ORGANIZATIONS.}

In six of the Canal Zone villages the Government maintains public clubhouses for its white American employes. The buildings contain waiting, reading and game-rooms, billiard-

Y. M. C. A. room, bowling-alleys, and dance-hall that is also used for public entertainments. When the policy of establishing these clubhouses was determined upon the only trained conductors of such institutions in the United States were the secretaries of the Young Men's Christian Association. The Association was called upon to take charge of the Canal builders' social centers for the dual reason that it had the machinery and men ready, and that it makes a good impression in the United States to have Government functions under the guidance of an organization definitely 
opposed to such social evils as alcoholism and gambling. It is a disadvantage that the clubhouses are furnished free (although ten dollars a year is charged for each person using them regularly, as a maintenance fee) because it is human nature to feel less interest in things given than in things striven for.

Part of the effort to establish home life, was the organization of women's clubs under the American Federation of Women's Clubs. These organizations flourished for a period of eighteen

Women's months; but soon the novelty wore off, and the diffiClubs. culty of making the meetings attractive to scores of women of divergent interests and ideas could not be overcome. In an American city these clubs are organizations of women of comparatively similar tastes and interests and therefore are self-cohesive. In the Canal Zone they were started by the Government, and gradually their membership has diminished until it numbers less than two hundred. These few, however, belong to the clubs because they wish to, and they make a much stronger organization than the larger numbers of 1908 and 1909 did: The meetings are devoted largely to discussions of questions of current interest, regular study courses are pursued, and domestic problems are discussed. A tropical cook-book, sanitary drinking cups in the schools and railway trains, free lectures on tuberculosis and other diseases prevalent in Panama, public playgrounds in Colon, Panama, and Gatun, and essay competitions in the schools are among the more tangible results of the organization.

Fraternal Friendly or fraternal societies, such as the

Societies. Masons, Odd Fellows, Knights of Pythias, Foresters,

Knights of Columbus, and Kangaroos, have lodges and hold regular meetings. Their influence is negligible.

The prime object of the trades unions, that of increasing wages and bettering the conditions of employment, is anticipated in work for the American Government by the enforcement of an eight-hour working day, and by higher wages than are paid in private employ. Therefore the trades unions represented among the Americans on the Canal and Panama Railroad are practically restricted to presenting petitions of the employes, and keeping alive the spirit of organization against the time when the men shall again enter private employ. Committees of the men are always at liberty to present grievances to the Chief Engineer, whether they represent a regularly organized union or only a local organization. Individuals are accorded a like privilege, although it is naturally much better to consider grievances of a whole class and clecide them at one time than to take up individual cases. The unions represented among the Canal workers include the International Brotherhood of Steamshovel and Dredgemen, the Brothertood of Locomotive Engineers, the Machinists, Boilermakers, Molders, and Electrical workers. There is a local organization of railway conductors. Meetings are held regularly, and contributions are made to the central organizations in the United States. In every case where there has been a threat of strike the central organization has advised the Canal men not to leave their work, because the conditions of it are so much better than in the United States.

The Spanish laborers have a political organization made up of men of various radical beliefs, called variously liberals, socialists and anarchists. Their meetings are held openly and the discussion 
is largely confined to such questions as temperance, gambling, and political conditions in Spain. In the only concerted movement of Spanish laborers that has taken place on the Canal or railroad, the leaders of the liberal clubs were the leaders of the men.

Such organizations as they had in the West Indies, the Englishspeaking negroes have transplanted to the Canal Zone. One is the West Indian Protective Association, which endeavors to present the claims of the negroes as a body, and its influence is unquestionably good, because its weekly bulletin emphasizs the need of right living. "The Land Ship" is an organization with several lodges, its claims on the men seeming to be like that of many of the American fraternal organizations. largely self-improvement and the joy of holding highsounding offices, such as Admiral, Commodore, and the like.

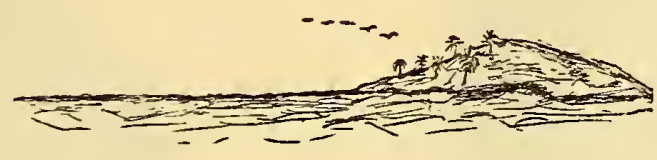




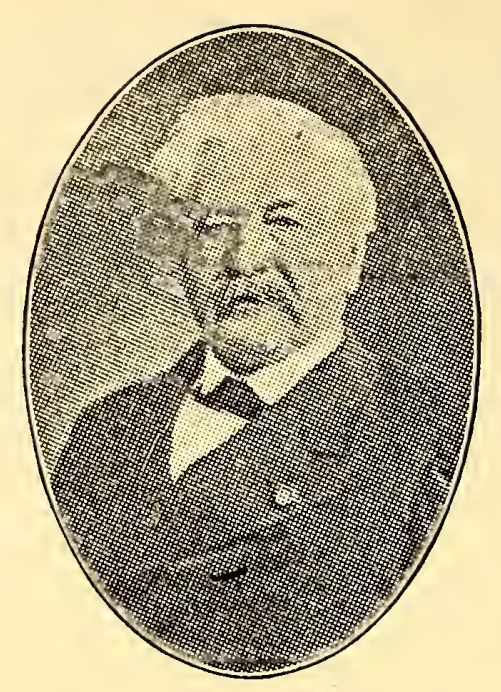

Ferdinand Vicomte de Lesseps

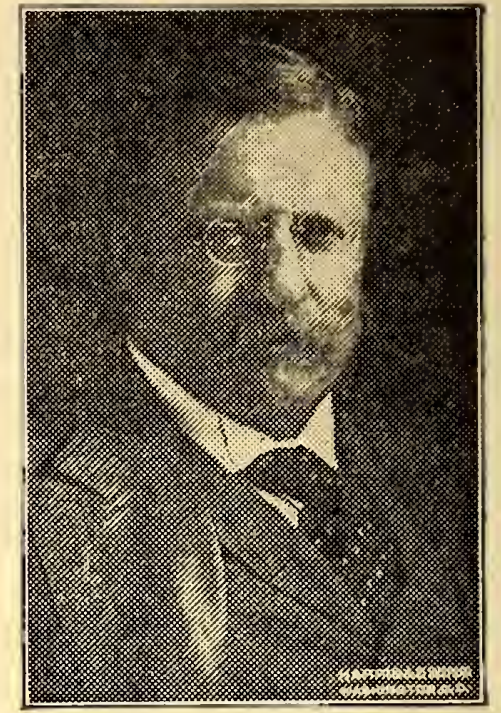

THEODORE ROOSEvelT

Ferdinand Vicomte de Lesseps. Born Versailles, 1805. Died 1894. Began Suez Canal project 1854; canal opened 1869. Panama Canal project 1879 to 1894. Lesseps was not an engineer but a promoter. Although convicted with his son of misappropriation of Panama Canal funds, it is believed he knew nothing about the frauds. His name was capitalized. He.was not in actual charge of the administration.

Theodore Roosevelt. Born, New York, 1858. Harvard College, 1880. President of The United States, September 14, 1901 to March 4, 1909. During his administration the independence of Panama was realized, and canal work organized.

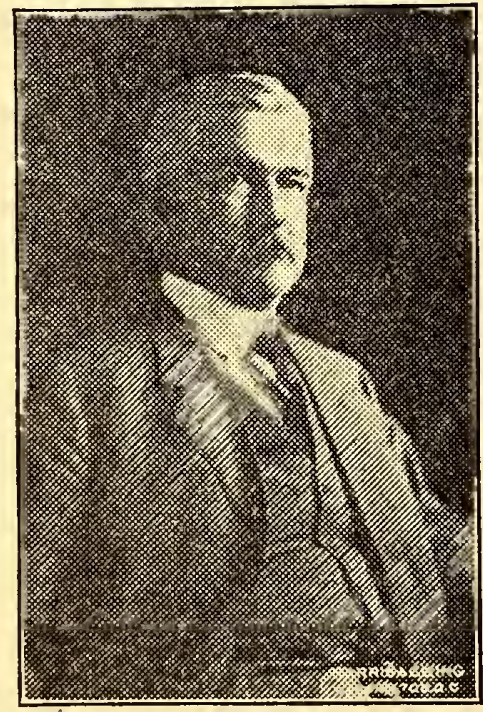

William CraWford Gorgas.

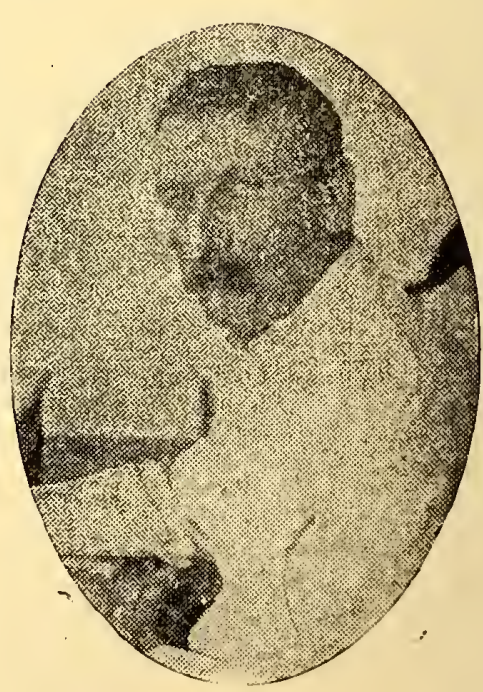

John F. Stevens.

William Crawford Gorgas, (Colonel, Medical Corps, U. S. A.) Born Mobile, Alabama 1854. Bellevue Hospital Medical School, 1879. First lieutenant, Medical Corps, 1880. Colonel by special act Congress 1903 for work as health officer of Habana. Chief Sanitary Officer, Isthmian Canal Commission, since June 1904. Member Isthmian Canal Commission, since March 4, 1907.

John F. Stevens. Born West Gardiner, Me., 1853. Builder, engineer manager of railroads. Chief Engineer Panama Canal, July 20, 1905 to April 1, 1907, Chairman of the Commission, February and March, 1907. 


\section{The Panama Canal}

When the Panama Canal is opened to navigation in 1915, it will be three hundred and eighty-one years since the first survey for a Canal was made; for neither the Americans nor the French were the first to dream about a canal across the Isthmus, nor even to investigate its possibility. Columbus touched at Nombre de Dios and Porto Bello, quite likely sailed into Limon Bay, in 1501, and he died believing that such a route existed. There were traditions of it among. the Indians, or of what sounded like it to the Spaniards; and Balbca, Pizarro, and others of the conquistadors, must have thought many times of the advantage of such a passage, as they toilsomely drove the enslaved natives, overladen with parts of ships and other cumbrous freight, over the mountain passes and through the jungles of Darien. As early as 1530 the Chagres River was used as a means of crossing to within 15 miles of the old city of Panama on the Pacific; and in 1534 Charles V of Spain had a survey made for a canal from the end of navigation on the Chagres to the Pacific. This is the route of the present Canal. At regular intervals from that time forth the project was discussed, and in 1814, Spain actually took active steps to construct a canal, but the revolution of her colonies put an end to the plans. The discussion, renewed by Von Humboldt in the closing years of the 18th century, has never ceased.

Although the Spaniards were the first to make a survey, and to consider as a national measure, the construction of a canal, the interest of the United States

Atrato, San has been constant since 1825, and more has Blas, Cale- actually been done by that Government in donia Routes. the matter of surveys and investigations than by all others together. Of the many routes surveyed between Tehuantepec and Colombia, the Nicaragua and Panama are the only ones ever seriously considered, and yet there are three others that have been made the subject of several investigations. 
The Atrato rou te is the most commonly known of these. There is an Indian legend that at a point on the headwaters of the Atrato a canoe can be carried for a distance of a mile and then floated on a river through which it can go without danger or interruption to the Pacific. The idea is that there is a point in the cordillera of Colombia at which the headwaters of the Atrato are very close to those of the Traundo, Napipi, Doonado, Bando, and San Juan. This is true. But the obstacles in the way of building a Canal on this route are greater than on any of the others. They include continual dredging along the Atrato River for a hundred miles, a cut through the continental divide that is greater than the cut at Culebra, and the canalizing of rivers on the Pacific side which for many miles are rugged mountain torrents. It is a dream of the Colombians' that some day they will build a barge canal along this route, thus connecting their eastern with their western domain.

A glance at the map will show that the Gulf of San Miguel on the Pacific side, and Calidonia Bay on the Atlantic are so close to one another that a route for a canal would seem to be possible there. This route has been surveyed, and the amount of excavation required makes the project many times more difficult than the Panama route. The same is true of the route from the Bay of San Blas on the Atlantic to the Bayano or Chepo River. The Isthmus at this point is at its narrowest, 35 miles, but the excavation required is so great that the only projects ever suggested included a tunnel 4.2 miles long, through which ships with masts 180 feet high must pass. The project has long been regarded as chimerical.

The Nicaragua route became the subject of actual investigation in 1825 , when the newly federated state of Central America, having established its independ-

Nicaragua ence from Spain, advised the United States Route. that it would encourage in every way any project by Americans for the opening of a canal from the Atlantic to the Pacific by way of Nicaragua. A company was immediately formed in New York, but it failed to raise the money for the surveys. An effort made by an English capitalist from 1826 to 1838 to interest capital in the project resulted in a reconnaissance survey, but no actual construction work. In 1839 the United States Government sent John L. Stephens to report upon a canal route, and after an examination of the isthmus both in Nicaragua 


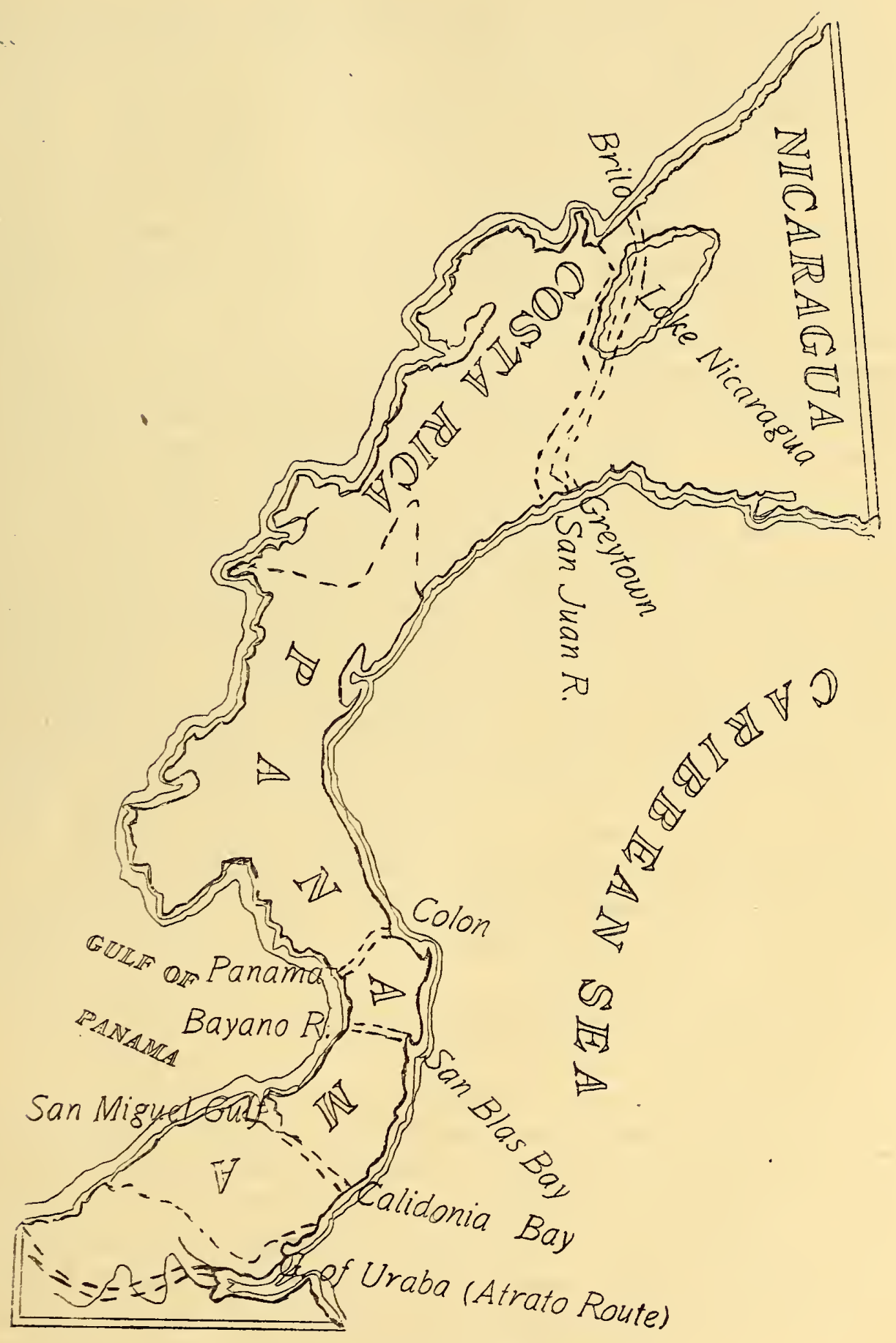

ISTHMIAN CANAL ROUTES.

Nicaragua, Panama, San Blas, Calidonia Bay, and Atrato. 
and Panama he reported in favor of Nicaragua, as being the less expensive. He later became one of the organizers of the Panama Railroad.

The canal projects were given a definite status by the ratification on July 5,1850 , of the Clayton-Bulwer treaty, by which the United States and the United Kingdom agreed to enforce the neutrality of any canal. Under this treaty, and an agreement with Nicaragua, a survey was made in 1850-1852 by an American, $O$. W. Childs, and a land transit route was opened, which carried on an extensive business by steamer and stage coach for several years, while the plans for a canal advanced. The concession was forfeited in 1858, and was renewed for a Frenchman, Felix Belly, who in turn forfeited his rights, for nonaction, ten years later. Another Frenchman, Michel Chevalier was given the franchise, but he also failed to begin the work.

In 1869, upon the recommendation of President Grant, the United States Government began a systematic survey of all the isthmian routes from Tehuantepec to the Atrato River, and in 1876 the commission, under which the surveys were executed, reported in favor of Nicaragua. A more complete survey of this route was made in 1885 by A. G. Menocal, and in February, 1889, the Maritime Canal Company of Nicaragua was incorporated under concessions from Nicaragua and Costa Rica. It was an American company with enough capital to make a beginning, and results of its work are still evident at Greytown and along the San Juan. It failed for lack of funds in 1893. The United States Government had meanwhile become interested in the project of its citizens, and on March 2, 1895, the Nicaraguan Canal Board was appointed to make further plans, it being understood that if the work were ever to be done the Government itself must do it. On November 16, 1901, this board, later known as the Isthmian Canal Commission, reported in favor of the construction of a canal across Nicaragua, providing the property of the New Panama Canal Company of France on the Isthmus of Panama, could not be purchased at $\$ 40,000,000$, about one-third of the price actually asked.

The Panama Canal project went through much the same course of development as the Nicaraguan. Surveys were made and remade, none of them thorough,

Panama until 1890, and each resulted in the verdict Route. "feasible," and estimates now known to have been grotesquely small. Bolivar in 1827 sent 
an English surveyor, J. A. Lloyd, to the Isthmus of Panama to survey a route for a wagon road or a canal. He recommended a wagon road from Limon (Navy) Bay to Panama, along the line of the Chagres River, knowing that the cost of a canal was far beyond the resources of the government.

In 1835, Gharles Biddle, sent by the United States Government to investigate routes across the isthmus, obtained from New Granada a concession for a railroad, but the prosecution of his plan was not deemed expedient at that time. In 1838, New Granada granted a similar concession to a company of Frenchmen, and a misleading report of a pass 37 feet above sea level caused the French Government to send Napoleon Garella to make a survey. He corrected the error, but recommended that a canal be built with summit level at 48 meters above the sea, a tunnel $3 \frac{1}{2}$ miles long, through the continental divide, and 18 locks to make the lift from the sea to the summit level. The opening of California and Oregon to settlement and the discovery of gold in California in 1849, gave the isthmian crossing new value, and the United States made a treaty with New Granada in 1848 to guarantee an open transit across Panama. The construction of the railroad $(1850-1855)$ had a deterrent effect on canal enterprises in Panama for some years, although surveys were made under direction of the United States Government in 1854 and 1866.

In May, 1876, the Government of Colombia (formerly New Granada) granted a concession for a canal to a French company, and under this concession the first work was done.

\section{The French Attempt.}

Surveys made for this company by Lucien Napoleon Bonaparte Wyse were the basis of the decision (May 15-29, 1879) by an international congress at Paris, in favor of a sea-level canal from the Bay of Limon to Panama Bay by way of the pass at Culebra. In 1881, The Universal Interoceanic Panama Canal Company, with Ferdinand de Lesseps as nominal head, took up the work. The canal was to be constructed, as the Suez Canal had been, as a business venture. On January 10, 1881 a ceremonial breaking of ground was performed by Lesseps himself at the Pacific entrance. Then followed a period of hasty surveys, assembling of machinery, and organizing and housing a working force. The first excavation was begun (January 
20, 1882) near the summit of the continental divide, at Empire, in the section now known as Culebra Cut. That was thirty years ago, and, barring three years, from 1888 to 1891 , work has been carried on at that point ever since

Their occupation was of much the same nature as the Americans, except that the French employed West Indian negroes in many positions where white men are now employed, and the proportion of French to the total force was therefore less. The work was done by contract, as the barge canal in New York State is now being constructed, and scores of Americans were employed in that way.

Right from the start they were handicapped. Yellow fever found the non-immune French easy victims, and malaria attacked both negro and white man.

Failure of The administration was hampered by interFirst French ference of the Colombian officials, the plans Company. were incomplete, and it was found at an early date that the estimate of cost $(\$ 127,600,000)$ was ridiculously low, and that more money must be raised. Meanwhile, the reports of death and sickness, the real magnitude of the enterprise, and the extravagant use of money in France, were making a bad impression on the French people; and the bonds of the company sold at a continuously lower price. In 1887 the sea-level project was abandoned for the time, as too costly, and a lock-level canal, to be deepened gradually to sea level, was decided upon.

On February 4, 1889, the company went into the hands of a receiver, and in the investigation that ensued great frauds in the administration of the company's affairs in France were disclosed. Ferdinand de Lesseps and others were convicted of fraud, although there is little evidence that Lesseps the elder was more than a figurehead, and it is likely that he knew nothing of the dishonesty. At the time of the disclosures, he was 86 years old, and he died soon after having been found guilty.

Little work was done on the isthmus until 1894, when The New Panama Canal Company, a receiver organization, began in earnest to complete the cut through the continental divide. It made extensive studies, and proceeded on the plan of a lock canal at two levels above the sea, to be reached by four locks on either side of the summit level. This canal was to have a ruling depth of 29 feet 6 inches, and a least width of 98 feet, as compared with $41 \frac{1}{3}$-foot depth and 300 foot least width of the present canal. The French continued 
to work in Culebra Cut until the Americans took possession on May 4,1904 . In all they had spent $\$ 255,000,000$ procured from securities of a face value of $\$ 435,000,000$. The loss was distributed among 200,000 bondholders, chiefly members of the French middle-class.

The ralue of the work done by the French was estimated in 1901 by the Isthmian Canal Commission of that time at $\$ 40,000,000$, and on this basis the rights of Work Done by the French company were acquired. An the French. estimate made by the present Commission in 1911 , based upon the known ralue of the French excavation and equipment is $\$ 42,799,826$, divided as follows:

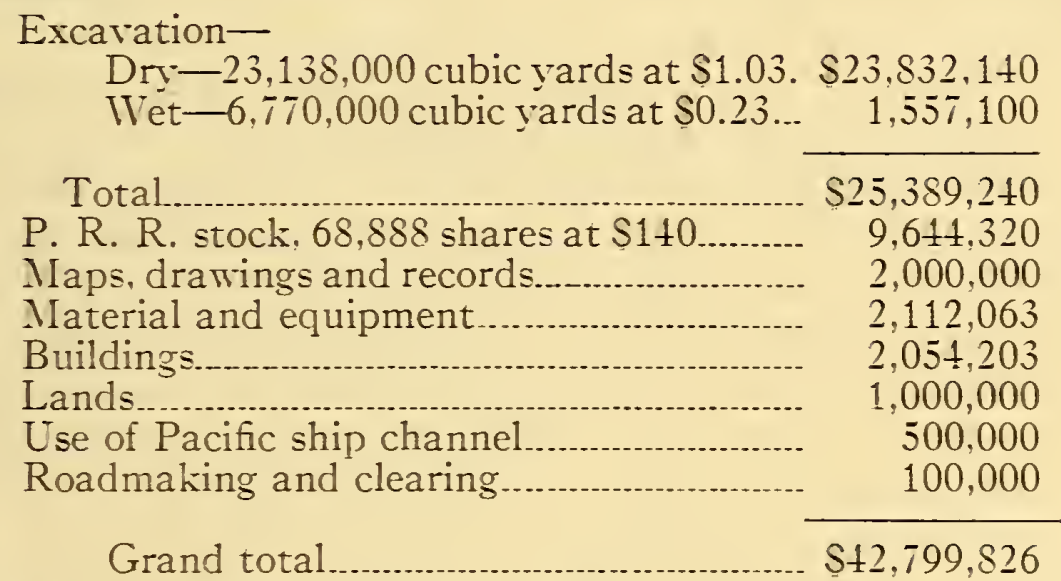

At the Pacific entrance the French had dredged a narrow channel from deep water three miles inland and this was used by ships going to Balboa (La Boca) docks. At the Atlantic entrance they had dredged a channel to Bohio, a distance inland of 15 miles, but it was navigable only by small boats of about seren feet draft. As far as Gatun, seven miles inland, it was fifteen feet deep, and the channel is used today in hauling materials between Cristobal and Gatun. All along the line of the Canal, work had been done, and one of the reminders of the failure up to a year ago were the old dredges and excavators which the tourist saw along the banks of the Chagres River as his train passed through the bottomland of the lake region.

The French canal line was practically the same as the American, utilizing the valleys of the Chagres and Rio Grande, in order to avoid excavation. The failure to build a canal was due mainly to the failure of the Paris management to retain the confidence of the French people. In four other ways the Americans have an advantage which the 
French did not possess-political control of the canal region, modern methods of maintaining health, more effective methods of excavating, unlimited money. In view of these differences Americans should be the first to join with the present Canal engineers in admiration of Lesseps' bold dream, and praise of the results accomplished by the men in the field.

\section{The American Canal.}

The story of the birth of Panama as a nation is told in another section of this book. The result of it was that the United States Government took possession of the effects of the French on the Isthmus on May 4, 1904, and the construction of the Canal under American auspices began on that day.

For several years the French had maintained a working force of a few hundred men in Culebra Cut, for the sole pur pose of holding the franchise until a purchaser could be found, or until a new organization with greater capital could be effected. Their machinery was stored all along the Canal line in sheds and shops, the larger pieces such as dredges and excavators not housed. All was well cared for, however, and much of it was immediately useful to the new builders. Yet there was much to be done before the work could proceed economically, and at first the Americans showed great lack of good sense in meeting their problem. The Commission in Washington was too cautious for success; and requisitions for material of all kinds were badly handled, because the men on the work were unable to persuade the officials in Washington that large quantities of materials were badly needed, and at once. Out of the conflict that thus ensued there came three definite policies: (1) Effective sanitation of the Canal Zone and the cities of Colon and Panama; (2) Recruiting a force and proper housing and feeding of employes in order to maintain it; (3) Concentration of power on the Isthmus.

\section{Sanitation and..Health.}

It was recognized in all comprehensive discussions of the Canal project that the work could not be done by Americans unless measures were first taken for placing the region of the work on a secure health basis. Plans for sanitation of Colon and Panama formed part of the discussion of the Commission of 1899-1901. The discovery and proof that mosquitoes carry yellow fever and malaria came just prior to 
the determination of the American Government to build the Canal, and this made the work of sanitation more easy. Yellow fever and malaria (in its worst form malaria was known as Chagres fever) were the diseases that had worked most havoc with the French forces, although there had been comparative freedom from the former for seven years prior to the American occupation.

The theory that malaria is carried by mosquitoes of the Anopheles species was demonstrated as true by Sir Ronald Ross of the British Medical service in India, who reached the conclusion after a long series of experiments by himself and others in 1898 . The story of the yellow-fever mosquito (Stegomyia) discovery is well told in an address delivered by the Secretary of the Isthmian Canal Commission, Mr. Joseph Bucklin Bishop, in 1910. In this case also the demonstration followed a long series of experiments begun by Dr. Carlos Findlay in Habana in 1881. It was made by Drs. Walter Reed, Jesse W. Lazear, James Carroll, and A. Agramonte of the American Army in Habana in 1901.

In January, 1904, the quarantine of Colon and Panama was turned over to the United States, and in June of that year the permanent sanitation organization was established, with Col. W. G. Gorgas, who had been Health Officer at Habana as head; and Dr. H. R. Carter, a yellow fever expert, as director of hospitals. This work like all the others was hampered by scarcity of supplies, notably copper wire screening, which could not be purchased in the United States in large quantities. An epidemic of yellow fever, lasting from July, 1904, to December, 1905, accelerated the delivery of supplies, and made it necessary to expedite the sanitation work, lest the force slowly organizing be depleted. There were 246 cases and 84 deaths, of which 134 cases and 34 deaths were among Canal employes, while all the cases were among the nonimmunes who had come to the isthmus on account of the Canal work.

The sanitation has in view the prevention of mosquito breeding and the maintenance of a high standard of cleanliness in all the settlements along the Canal.

Mosquito The anti-mosquito campaign is directed work against two species, the Stegomyia, which carries yellow fever, and the Anopheles which carries malaria. The Stegomyia lives in and about habitations, breeding in wet places. The measures taken against it 
were the fumigation of houses, and the exercise of care that no tins or other vessels in which water might collect be allowed to lie around the yards or houses. It took over a year to stamp out the yellow fever, but it may never again be known in Panama; because, if a rigid quarantine is maintained, there will be no chance for it to get a start here. The method of contagion is for a Stegomyia to bite a person infected with the fever and then to bite one not so infected. If the person first bitten is in a certain stage of the disease, and the mosquito biting him is in a certain stage of its development, the disease may be carried.

The Anopheles is less easy to control, because it breeds anywhere that there is a damp place on the edge of pools and streams, in the hoof marks left by cattle in the fields, in cans containing water, and even in high grass into which the sun does not penetrate. It carries malaria in much the same way as the Stegomyia carries yellow fever. Measures taken against it are the cutting of all grass and shrubbery around settlements so as to let the sunlight dry the damp places; covering pools, that cannot be drained, with a film of oil, which smothers the larvae before they reach maturity; and pouring into other streams and pools a mixture of carbolic acid, caustic soda, and rosin, known as larvacide, to kill the larvae.

The screening of houses is directed against all mosquitoes, but especially against the Anopheles. The ordinary method of treating malaria is with large doses of quinine, while many people take small doses continually for prophylactic purposes. By systematic treatment the type of malaria has been reduced from one of great violence to a very mild one, and the sick rate from 821 cases per thousand employes in 1906 to $187^{\circ}$ cases per thousand employes in 1911 .

An important part of the sanitation work was the municipal engineering in the cities of Colon and Panama, and in the Canal villages. In Colon it consisted of fill-

Municipal ing the swampy land upon which the city was Enginecring. built, laying sewers, and installing a general water system, and laying pavements; in Panama the laying of sewers and pavements, and installing water mains; in the Canal villages, sewer and water work, and the laying out and macadamizing of roads. This work was begun in 1905 and finished in 1906 . In the cities of Colon and Panama it is being paid for by water rents collected by an American Superintendent of Public Works. 
At present a strict quarantine against contagious diseases is maintained; the villages and quarters are kept in the cleanest possible condition; light, air, pure

Health water, and good sewerage are insisted upon. Statistics. The corollary is that the general health is good. The effectiveness of the public-health work can be best judged from the following statistics of employes admitted to hospitals, rate per thousand of employes, and death rate per thousand of employes for each fiscal year:

\begin{tabular}{|c|c|c|c|}
\hline YEAR & $\begin{array}{l}\text { Number } \\
\text { ADMITTED }\end{array}$ & $\begin{array}{l}\text { RATE PER } \\
\text { THOUSAND } \\
\text { EMPLOYES }\end{array}$ & $\begin{array}{l}\text { DEATH } \\
\text { RATE PER } \\
\text { THOUSAND }\end{array}$ \\
\hline $1904^{*}$ & & & -13.26 \\
\hline $\begin{array}{l}1905^{*} \\
1906^{*}\end{array}$ & & & 25.86 \\
\hline $1906^{*}$ & 31,025 & 1,169 & 41.73 \\
\hline $1907 .$. & 31,037 & 960 & 39.47 \\
\hline 908. & $21,361 \ldots$ & $496 \ldots$ & 18.32 \\
\hline $1909 \ldots$ & $21,782 \ldots$ & $492 \ldots$ & 11.97 \\
\hline 1910. & 20,753 & 411 & 10.84 \\
\hline & $22,832 \ldots$ & 465 & $\ldots 11.34$ \\
\hline 12 & $21,919 \ldots$ & 438 & $\ldots 10.16$ \\
\hline
\end{tabular}

These figures would be misleading were they not considered in view of the facts that all employes are given a physical examination before being allowed to enter the service, the force is made up of young men, and chronic invalids are deported to their home countries as soon as their services are no longer available for the Canal work. Making allowance however for these qualifying conditions, the sanitation of the Canal Zone and the cities of Colon and Panama justifies the statement made by Col. Gorgas:

"Natives in the tropics, with the same sanitary precautions that are taken in the temperate zones, can be just as healthy and have just as small. a death-rate as inhabitants in the temperate zones. To bring this about, no elaborate machinery is necessary. The result can be attained by any community, no matter how poor, if it is willing to spend 'sufficient labor in cleaning, and to observe well-known rules with regard to disease. The Anglo-Saxon can lead just as healthy a life, and live just as long in the tropics as he can in his native climate." (See also pages 37,51, )

\section{Labor Force, and Housing.}

The working force is composed principally of West Indian negroes and Spanish laborers, and white Americans who do the skilled labor and administrative work. When the force was at its highest point, March, 1910, there were at work 
38,176 men and 500 women, and the total number of names on the pay rolls was 50,774. These included 5,235 Americans, 5,263 European laborers, and 28,178 negro laborers. The force grew from 700 on May 4, 1904, principally negro laborers, to 3,500 in $1905 ; 17,000$ in $1906 ; 29,000$ in 1907 ; and is now decreasing gradually, and will decrease until the Canal is opened, when there will be employed about 3,000 men to maintain and operate the Canal, and do the work of sanitation and government.

The development of the force during the first three years depended largely on the rapidity with which quarters could be furnished. Immediately upon his arrival on

Quarters. the Isthmus in June, 1904, the first Chief Engineer, John F. Wallace, began to perfect an organization, and in it was included a division of building construction. Old French buildings were repaired as rapidly as possible, and a few new buildings were erected. Under the second Chief Engineer, John F. Stevens, this work was carried forward, and the quarters as one now sees them on the Canal Zone were practically completed during the first year of the Goethal's regime, 1907. The organization of the labor force was directed by Mr. Jackson Smith assisted by Lieut. R. E. Wood.

Laborers' barracks are one-story buildings in which stanciee bunks are erected, and where provision is made for the storage of a limited amount of baggage on the lofts. These buildings are screened against mosquitoes and cleaned daily. When the force was largest, 5,000 Spanish laborers and 6,000 negroes were quartered in these bunk houses. Barracks for white American bachelors consist of buildings of from four to thirty-two rooms, where the men sleep usually two in a room. They are furnished with beds, chiffonier, bureau, table, and chairs.

Family quarters of the lowest grade (all quarters are graded according to salary of employee) are two-room houses with kitchen and toilet room, occupied by families of laborers. There are only a few of these. White family quarters are generally of four rooms, kitchen, and bath, except those for the higher officials, which contain more rooms. Furniture is supplied with each house. All quarters are lighted with electricity, furnished with water, and coal is supplied for cooking. It is part of the contract with employes who en- 
tered the service prior to January 1,1908 that their quarters, light, water, and fuel would be furnished without charge. All bachelors are employed on this understanding. The statement that the Government furnishes them free is therefore erroneous because many employes have been induced to come to Panama by these little "extras," and they form, therefore, part of the pay. The Quartermaster's Department has charge of the housing and labor recruiting.

Food is supplied through the commissary stores, and messes. See page 99.

\section{The C.anal Zone.}

In the treaty of February 26, 1904, Panama conceded in perpetuity to the United States the use, occupation, and control of a strip of land 10 miles wide, 5 miles on either side of the center line of the Canal, extending from a line in the Pacific ocean 3 marine miles from mean low water mark to a similar line in the Atlantic, with the cities of Colon and Panama excepted. The rights of sovereignty were conceded, within this territory. In return the United States paid to Panama $\$ 10,000,000$ cash, and will pay an annual rental of $\$ 250,000$ after February 26, 1913. The territory is 448 square miles in area, about 322 square miles of which is held by the United States Government. (See also Canal Zone census). The government is an autocracy limited by a code of laws based upon the "bill of rights" of the United States Constitution. The Constitution extends to the Canal Zone only by special act of the Congress. All officials are appointed by the President of the United States.

\section{The Administration.}

After the many experiences that the United States has had in its short history to demonstrate the futility of such a policy, it was almost ludicrous to attempt to direct the greatest work it has ever undertaken from the capital at Washington. Yet this was the plan that so independent a thinker as Theodore Roosevelt, and so careful an executive as William H. Taft, as Secretary of War, allowed to be tried in the early days of the canal. They were among the first to see the mistake, and acted as quickly as they could to overcome it. The Isthmian Canal Commission of 1904 was composed of Rear Admiral John G. Walker, U. S. N., chairman; and members Maj. Gen. Geo. W. Davis 
U. S. A., W. B. Parsons, W. H. Burr, B. M. Harrod, G. E. Grunsky, civil engineers; and F. J. Hecker. General Davis was sent to Panama as resident agent of the Commission and Governor of the Canal Zone. Under adverse conditions he did good work. This is true also of the first Chief Engineer, John F. Wallace, who for a whole year was not a member of the Commission.

The unwieldiness of the Commission made President Roosevelt and Mr. Taft recommend to Congress, that the commission form be abolished and power be given the Executive to appoint a more wieldy administrative body. This Congress refused to do. Roosevelt overcame the difficulties partly by appointing a new commission in April, 1905, of which the Chief Engineer was a member. This consisted of Theodore P. Shonts, chairman; Charles E. Magoon, Governor of the Canal Zone; John F. Wallace; Rear Admiral Mordecai T. Endicott, U. S. N.; Brig. Gen. P. G. Haines, U. S. A.; Col. O. H. Ernst, Corps of Engineers, U. S. A.; and B. M. Harrod. On June 28, 1905, Mr. Wallace, the Chief Engineer, resigned, and John F. Stevens was appointed in his place. This organization continued until March, 1907. Under it the work of preparation was completed, and excavation in Gulebra Gut was begun on an extensive scale, and on the plan since pursued.

The first concentration of power came in the appointment of an executive committee composed of the Chairman, the Governor of the Canal Zone, and the Chief Engineer, and the latter two, residing on the Isthmus, had power to bind the Commission with regard to purely isthmian affairs. In September, 1906, Mr. Magoon was made Governor of Guba, and the organization was further concentrated by placing all affairs of the Canal in the United States under the Chairman of the Commission, and all those on the Isthmus under the Chief Engineer. Early in 1907, Mr. Shonts resigned, and Mr. Stevens was made Chairman and Chief Engineer, with practically unlimited power.

On April 1, 1907, Mr. Stevens resigned, and a new commission was appointed composed of Geo. W. Goethals, Chairman and Chief Engineer; D. D. Gaillard, W. L. Sibert, of the Corps of Engineers, U. S. A.; W. C. Gorgas, of the Medical Corps, U. S. A.; H. H. Rousseau, of the Civil Engineer Corps, U. S. N.; Jackson Smith, who had organized the working force and quartering system under Mr. Stevens; and Jo. G. S. Blackburn, as Head of the Department of Civil 
Administration. Mr. Smith resigned in June, 1908, and was succeeded by H. F. Hodges, Corps of Engineers, U. S. A. Mr. Blackburn resigned in December, 1909, and was succeeded by $M$. H. Thatcher.

On January 6, 1908, President Roosevelt made an executive order further increasing the administrative power of the Chairman. By law and the development of conditions, the Chairman has exercised since that time a practical dictatorship over the Canal work and Canal Zone Government. The organization of the work as now carried on under him is as follows:

\section{ISTHMIAN CANAL COMMISSION.}

Col. George W. Goethals, U. S. A., Chairman of Commission, Chief Engineer of Canal. Governor of Canal Zone, President of Panama Railroad, Resident member of Panama Fortification Board.

Col. H. F. Hołges, U. S. A., Assistant Chief Engineer, Vice President Panama Railroad.

Lieut. Col. D. D. Gaillard, U. S. A., Division Engineer.

Lieut. Col. Wm. L. Sibert, U. S. A., Division Engineer,

Mr. H. H. Rousseau, Civil Engineer, U. S. N., Assistant to the Chief Engineer.

Col. W. C. Gorgas, U. S. A., Chief Sanitary Officer.

Mr. Maurice H. Thatcher, Head of Department of Civil Administration.

Mr. Joseph Bucklin Bishop, Secretary of the Commission.

\section{DEPARTMENTS AND DIVISIONS.}

\section{Construction and Engineering.} Headquarters, Culebra.

Col. Geo. W. Goethals, Chairman and Chief Engineer.

William Howard May, Secretary to the Chairman.

C. A. McIlvaine, Chief Clerk.

Ad. Faure, Chief Accountant.

H. S. Farish, Surveying Officer.

Lieut. Geo. R. Goethals, U. S. A., Assistant Engineer.

Col. H. F. Hodges, Assistant Chief Engineer.

C. O. Carlson, Secretary.

Edward Schildhauer, Electrical and Mechanical Engineer.

Henry Goldmark, L. D. Cornish, T. B. Monniche, Designing Engineers.

Walter F. Beyer, Assistant Engineer

Civil Engineer H. H. Rousseau, Assistant to the Chief Engineer.

J. C. Parsons, Secretary.

Maj. T. C. Dickson, U. S. A., Inspector of Shops.

A. B. Nichols, Office Engineer.

Civil Engineer U. S. N., F. H. Cooke, Assistant Engineer.

James G. Craig, D. E. Irwin, Traveling Engineers.

Atlantic Division.

Headquarters, Gatun.

Lieut. Col. Wm. L. Sibert, Division Engineer.

Major Chester Harding, U. S. A., Assistant Division Engineer.

\section{Ben Jenkins, Chief Clerk.}

Maj. J. P. Jervey, U. S. A., Maj. G. M. Hoffman, U. S. A., Resident Engineers.

Geo. M. Wells, Office Engineer.

\section{Central Division.}

Headquarters, Empire.

Lieut. Col. D. D. Gaillard, Division Engineer.

W. I. Beam, Chief Clerk.

A. E. Bronk, General Inspector.

A. S. Zinn, Resident Engineer.

Mark W. Tenny, Assistant Engineer.

J. W. Sneed, J. M. Hagan, Joseph Little, W. T. Reynolds, Superintendents of Construction.

A. Sessions, Superintendent of Transportation.

William H. Bates, Superintendent Steam-shovel Repairs.

Dan E. Wright, Superintendent Municipal Work and Pipe Lines.

\section{Pacific Division.}

Headquarters, Corozal.

S. B. Williamson, Division Engineer.

John M. G. Watt, Assistant Division Engineer.

J. C. Keller, Chief Clerk.

W. G. Comber, H. O. Cole, Resident Engineers.

Frank Cotton, H. D. Hinman, IV. L. Thompson, Assistant Engineers.

James Macfarlane, Superintendent of Dredging. 


\section{ISTHMIAN CANAL COMMISSION-DEPARTMENTS AND DIVISIONS-(Continued.)}

Mechanical Division.

Headquarters, Gorgona.

A. L. Robinson, Superintendent. William Taylor, Chief Clerk.

Henry Schoellhorn, Mechanical Engineer.

Subsistence.

Headquarters, Cristobal.

Lieut. Col. Eugene T. Wilson, U. S. A., Subsistence Officer.

Capt. Frank O. Whitlock, U. S. A. Assistant Subsistence Officer.

John Burke, Manager of Commissaries. W. F. Shipley, Chief Clerk.

\section{Quartermaster's.}

Headquarters, Culebra.

Col. C. A. Devol, U. S. A., Chief Quartermaster.

Capt. R. E. Wood, U. S. A., Assistant Chief Quartermaster.

Lieut. Walter D. Smith, U. S. A., Constructing Quartermaster.

C. H. Mann, Chief Clerk.

Capt. Courtland Nixon, U.S. A., Depot Quartermaster, Mount Hope.

C. L. Parker, Assistant Depot Quartermaster, Mount Hope.

Civil Administration.

Headquarters, Ancon.

Maurice H. Thatcher, Head of Department.

G. A. Ninas, Chief Clerk.

C. L. Lued tke, Assistant Chief Clerk.

Tom M. Cooke, Chief, Division of Posts, Customs, and Revenues, Ancon.

Arthur McGown, Deputy Collector, Ancon.

Jno. L. Storla, Deputy Collector, Cristobal.

Capt. Chas. W. Barber, U. S. A., Chief of Police, Ancon.

C. E. Weidman, Fire Chief, Cristobal.

Chas. F. Koerner, Assistant Fire Chief, Ancon.

M. E. Gilmore, Superintendent of Public Works, Ancon.

J. J. Reidy, Assistant Superintendent of Public Works, Colon.

F. A. Gause, Superintendent of Schools, Ancon.

Edgar P. Beck, Treasurer of Canal Zone, Empire.

W. G. Comber, Chairman; James Macfarlane, C. J. Anderson, Board of Local Steamboat Inspectors.

\section{Canal Zone Judiciary.}

Headquarters, Ancon.

Supreme Court-H. A. Gudger, Chief Justice.

Walter Emery, Clerk, Ancon.

Thomas E. Brown, Jr., Associate Justice.

William H. Jackson, Associate Justice.

Circuit Court, First Circuit-H. A. Gudger, Judge.

Circuit Court, Second Circuit-William H. Jackson, Judge.
Circuit Court, Third Circuit-Thoma E. Brown, Jr., Judge.

M.C. Rerdell, District Judge, Cristobal. S. E. Blackburn, District Judge, Ancon. Edgar S. Garrison, District I udge, $\cdot$ Empire.

J. B. March, District Judge, Gorgona. Law.

Headquarters, Ancon.

Frank Feuille, Counsel and Chief Attorney.

William K. Jackson, Prosecuting Attorney.

Chas. R. Williams, Assistant Prosecuting Attorney.

A. A. Greenman, Land Agent.

\section{Sanitation.}

Headquarters, Ancon.

Col. W. C. Gorgas, Chief Sanitary Officer.

Col. John L. Phillips, U. S. A., Assistant Chief Sanitary Officer.

Maj. R. E. Noble, General Inspector.

Harry E. Bovay, Chief Clerk.

Lieut. Col. Charles F. Mason. U. S. A., Supt. Ancon Hospital, Ancon.

Surgeon Wm. H. Bell, U. S. N., Superintendent Colon Hospital.

Surgeon J. C. Perry, P. H. and M. H. S., Chief Quarantine Officer, and Health Officer, Panama.

Surgeon Claude C. Pierce, P. H. and M. H. S., Quarantine Officer, Colon.

Dr. Fleetwood Gruver, P. H. and M. H. S., Quarantine Officer, Panama.

Joseph A. LePrince, Chief Sanitary Inspector, Ancon.

Dr. M. E. Connor, Health Officer. Colon.

Disbursements.

Headquarters, Empire.

Edward J. Williams, Disbursing Officer.

Wm. M. Wood, Assistant Disbursing Officer.

Examination of Accounts. Headquarters, Empire.

H. A. A. Smith, Examr. of Accts.

T. L. Clear, Assistant Examiner of Accounts.

Purchasing Department.

Headquarters, Washington, D. C.

Maj. I. C. Boggs, U. S. A., General Purchasing Officer.

C. E. Dole, Chief Clerk.

Capt. Courtland Nixon, Purchasing Agent on the Isthmus.

Panama Railroad Company. (General offices, 24 State Street, N. Y.) E. A. Drake, First Vice-President.

Headquarters, Colon.

J. A. Smith, Gen. Supt., Colon.

R. L. Mock, Chief Clerk.

Lieut. Frederick Mears, U. S. A., Chief Engineer.

A. K. Stone, Master of Transportation. 


\section{Sea Level or Lock Plan.}

"I cannot venture to predict the time required and the amount of money necessary for the construction of a sea-level canal,' said the present Chief Engineer, Col. Geo. W. Goethals, before a committee of Congress when asked to give an estimate for a sea-level canal. As a matter of fact the only sea-level project scientifically considered was that of the Consulting Engineers of 1906. The estimates for the lock-level project then made were soon found to be grossly inadequate, both as to the cost of the original project and the size of the project itself, so these are of little value in estimating for a sea-level canal. The reasons why a sea-level canal is not being constructed are that it would cost so much, take so much time, and in the end be of less value than the present Canal, with its broad lake channels.

The question was settled in January, 1906, when the International Board of Consulting Engineers, by vote of 8 to 5 decided in favor of a sea-level canal, and President Roosevelt recommended that Congress adopt the plan for a lock-level canal submitted by the minority. In favor of the minority plan were 5 of 7 members of the Isthmian Canal Commission and Chief Engineer Stevens. The Board consisted of Geo. W. Davis, U. S. A., Messrs. Alfred Noble, W. B. Parsons, W. H. Burr, Brig. Gen. Henry L. Abbott, Corps of Engineers, U. S. A.; Frederick P. Stearns, Joseph Ripley, and Isham Randolph of the United States; W. H. Hunter of England, Eugene Tincauzer of Germany, Adolph Guerard of France, E. Quellennec of France, and J. W. Welcker of The Netherlands. The report in favor of the canal at sea level was signed by Messrs. Davis, Parsons, Burr, Hunter, Guerard, Tincauzer, Welcker, and Quellennec. President Roosevelt summed up the case as follows:

"A careful study of the reports seems to establish a strong probability that the following are the facts: The sea-level Canal would be slightly less exposed to damage in the event of war; the running expenses, apart from the heavy cost of interest on the amount employed to build it, would be less; and for small ships the time of transit would probably be less. On the other hand, the lock Canal at a level of 80 feet or thereabouts would not cost much more than half as much to build and could be built in about half the time, while there would be very much less risk connected with building it, and for large ships the transit would be quicker; while, taking into account the interest on the amount saved in building, the actual cost of maintenance would be less. After being built it 
would be easier to enlarge the lock canal than a sea-level canal. Moreover, what has been actually demonstrated in making and operating the great lock canal, the Soo, a more important artery of traffic than the great sea-level canal, the Suez, goes to support the opinion of the minority of the Consulting Board of Engineers and of the majority of the Isthmian Canal Commission as to the superior safety, feasibility, and desirability of building a lock Canal at Panama."

\section{Lake-Level Plan.}

The essential features of the plan adopted, and now nearing completion, are a lake at 85 feet above mean sealevel, and two approaches to it at sea level. The lake is held at its high level by two dams, one at Gatun and one at Pedro Miguel, and ships will pass from one level to another in locks. The route chosen is $\mathbf{5 0}$ miles long, and it follows the bed of the Chagres River on the north side of the continental divide, and that of the Rio Grande on the south side, thus making use of the natural lay of the land to minimize the amount of excavation.

In trying to understand the plans for the work the tourist should keep in mind that the isthmus runs east and west, that Colon and the Atlantic ter-

Passage of minal of the Canal are north and west of

Ships. Panama Gity, which is near the southern or Pacific terminus. With the directions in mind suppose yourself on a ship bound from New York or Liverpool to San Francisco, then the general direction of your voyage, which is from east to west, will be changed when you reach the Panama Canal to a north to south direction.

The ship will enter the Canal in Limon Bay, and under its own steam proceed to Gatun. The place on the isthmus where the plan can best be seen is at Gatun, where the Atlantic entrance, the locks, the partly filled lake and the ship channel through it, all lie before the eye. Gatun Locks are seven miles inland. At the entrance to the locks the ship will anchor and wait until it is taken in tow by four electric towing locomotives, two ahead pulling and two behind exerting such back pull as will keep the ship steady between lines of taut hawsers, while it moves through the locks. It makes its ascent in three steps each lifting it $28 \frac{1}{3}$ feet, the total of 85 feet representing the difference between the level of the sea and the lake level.

Entering one of the sea-level chambers, the gates will be shut behind the ship, and water will be let in from the 


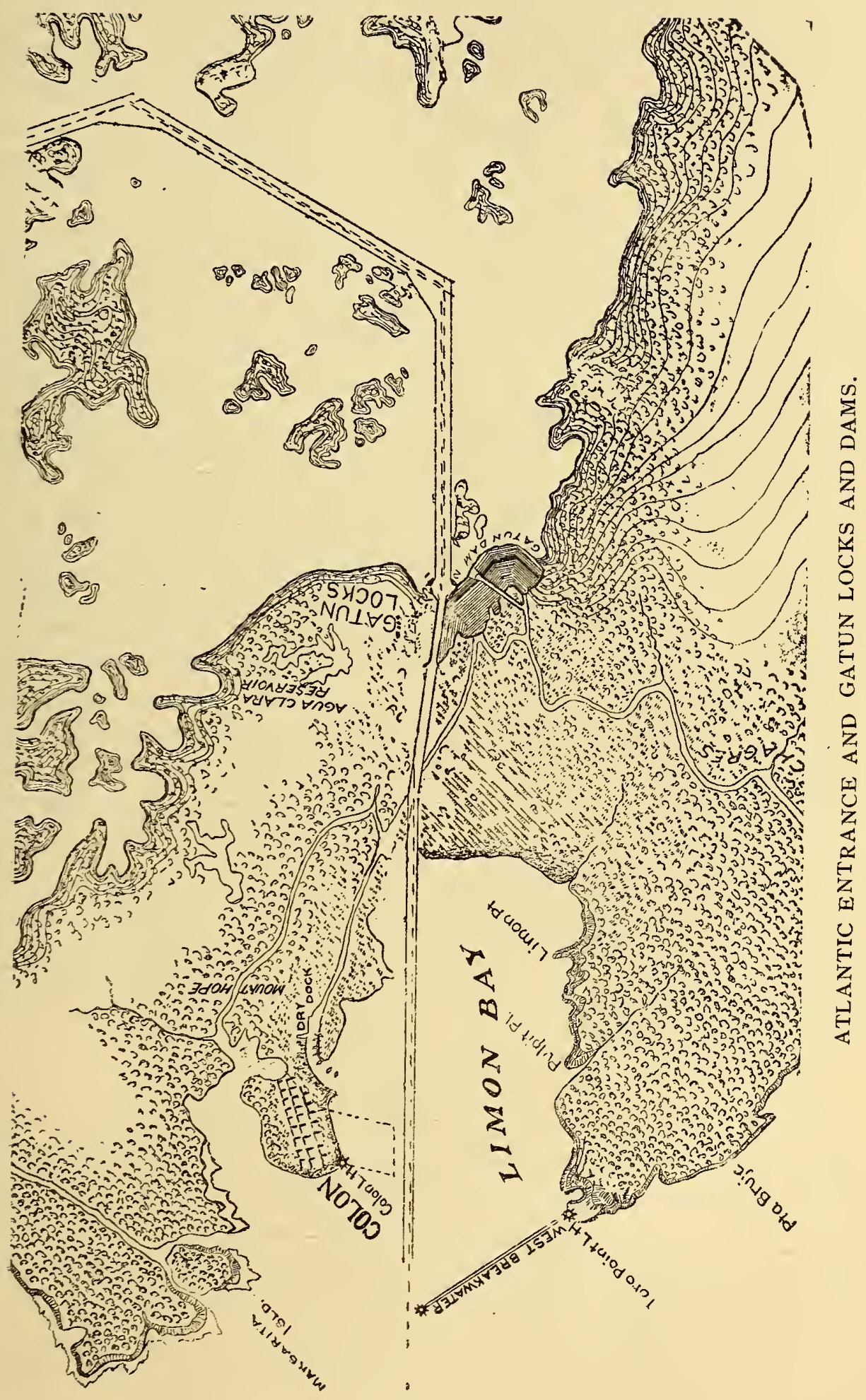


lake through a system of culverts in the lock walls and under the floors, until the ship has been raised $28 \frac{1}{3}$ feet above sealevel. It will then be towed into a second lock chamber, the gates will be closed, and the water let in from the lake will raise it another $28 \frac{1}{3}$ feet. In a third lock chamber, this process will be repeated, and the ship will then be at 85 feet above sea-level, when it will be towed out from the locks into Gatun Lake.

Under its own steam the vessel will proceed up a broad channel past scores of little islands, green with the unfailing verdure of the tropics, past native hamlets and isolated huts, for a distance of $\mathbf{1 6}$ miles, when the broad waters will be left behind, and the hills will close in, leaving a channel only 500 feet wide. Six miles farther on, the channel will narrow to 300 feet, and the ship will enter the pass through the continental divide, commonly known as Culebra Cut.

In this section. nine miles in length, the hills will rise sheer at places, and again will slope gradually away, but at no point will one be able to see the surrounding country from the deck. At Culebra the opposing hills will rise five hundred feet above the water level, great masses of igneous rock. This is the summit of the divide, and within sight is the lock at Pedro Miguel, where the descent to the Pacific is begun. After leaving this lock, the ship will sail through a small lake called Miraflores Lake, a distance of one mile, at an elevation of 55 feet above sea level; and then entering the double flight of locks at Miraflores will be lowered to the sea-level channel, through which it will sail a distance of seven miles to deep water in Panama Bay. The time of passage need not exceed eleven hours, at least three of which will be used at the locks.

\section{Sea-Level Channels.}

The sea-level channels or approaches will have a bottom width of 500 feet. That at the Atlantic entrance will begin at a point in Limon Bay, 41 feet below mean sea-level, about four and one-half miles from the shore line. The maximum tidal oscillation in this bay is two feet, and the channel will therefore be 40 feet deep at the lowest stage of the tide. A breakwater extending from the west shore of the bay in a northerly direction guards the entrance against the heavy winds that blow from the north during November, December, and January. The excavation here is done by two elevator-dredges brought to the Isthmus by the French, a dipper dredge of American make, and a sea-going hopper 


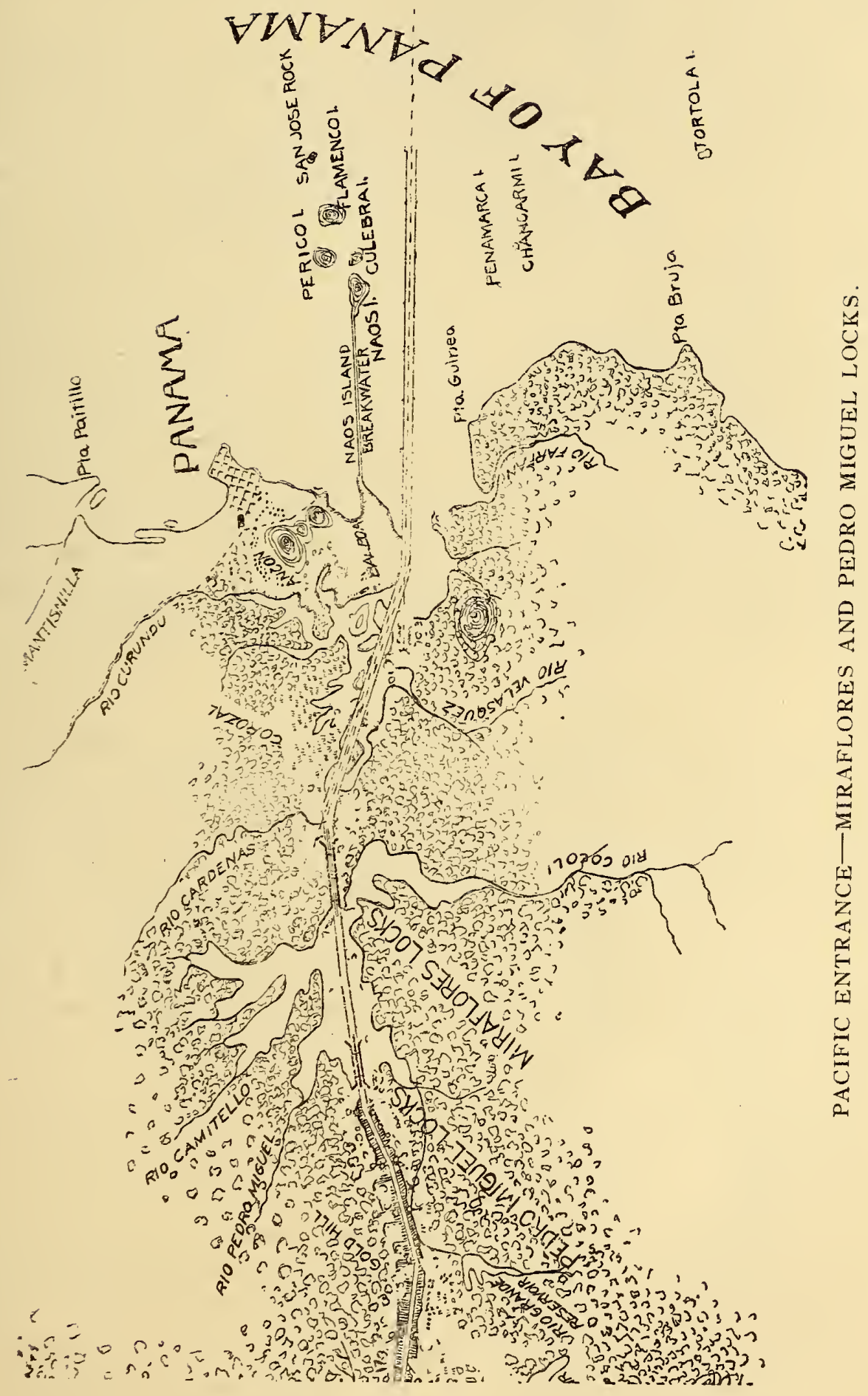


suction-dredge, also made in the United States. Inside the shore line the channel location ran through two small hills, and these have been dug out by steam-shovels to a depth of 41 feet below sea level.

The Pacific entrance or sea-level channel is subject to a maximum tidal oscillation of 20 feet, and therefore the depth has been made 45 feet below mean tide. At the lowest stage of the tide this section of the canal will be 35 feet deep. The channel begins in Panama Bay about four miles from the shore line, and, excepting a mile at the outer end, follows the line of the French canal to Miraflores Locks, a distance of 7 miles, utilizing the French excavation almost the entire distance. The excavation in this section is accomplished by two elevator-dredges of the Belgian type and two Scotch-type elevator-dredges left on the Isthmus by the French, a modern Scotch elevator-dredge built at Renfrew in 1911, and a subaqueous rock breaker of the Lobnitz-ram type. A breakwater extending from the mainland to an island in the bay, parallel with the canal, protects the channel in the bay from cross currents.

\section{The Locks.}

There are three flights of twin locks on each side of the Isthmus, to accomplish the lift from sea level to the lake level, and vice versa. Thus ships can be locked both up and down at one time, and a stoppage of traffic on account of an accident in one series of locks is anticipated by having a duplicate series. Each lock is a concrete chamber that can be closed at either end by steel gates, so that a ship can be raised or lowered in it simply by admitting or withdrawing water. Each chamber will admit a ship 1,000 feet long and 110 feet wide with a draft of 40 feet. This draft is provided for by a depth of fresh water over the gate sills of $41 \frac{1}{3}$ feet. This is also the greatest depth at which a vessel can enter New York harbor, and thus there are two factors that will be potent in making it the maximum draft of future ships. The largest ship now projected can easily use the locks of the Panama Canal. Most of the vessels in the isthmian trade or that are likely to be in it for many years to come, in fact 95 per cent of the ocean vessels in the world, are less than 600 feet long; and in order to save water and time in making lockages each lock is divided by intermediate gates into two chambers 400 and 600 feet long, respectively. 


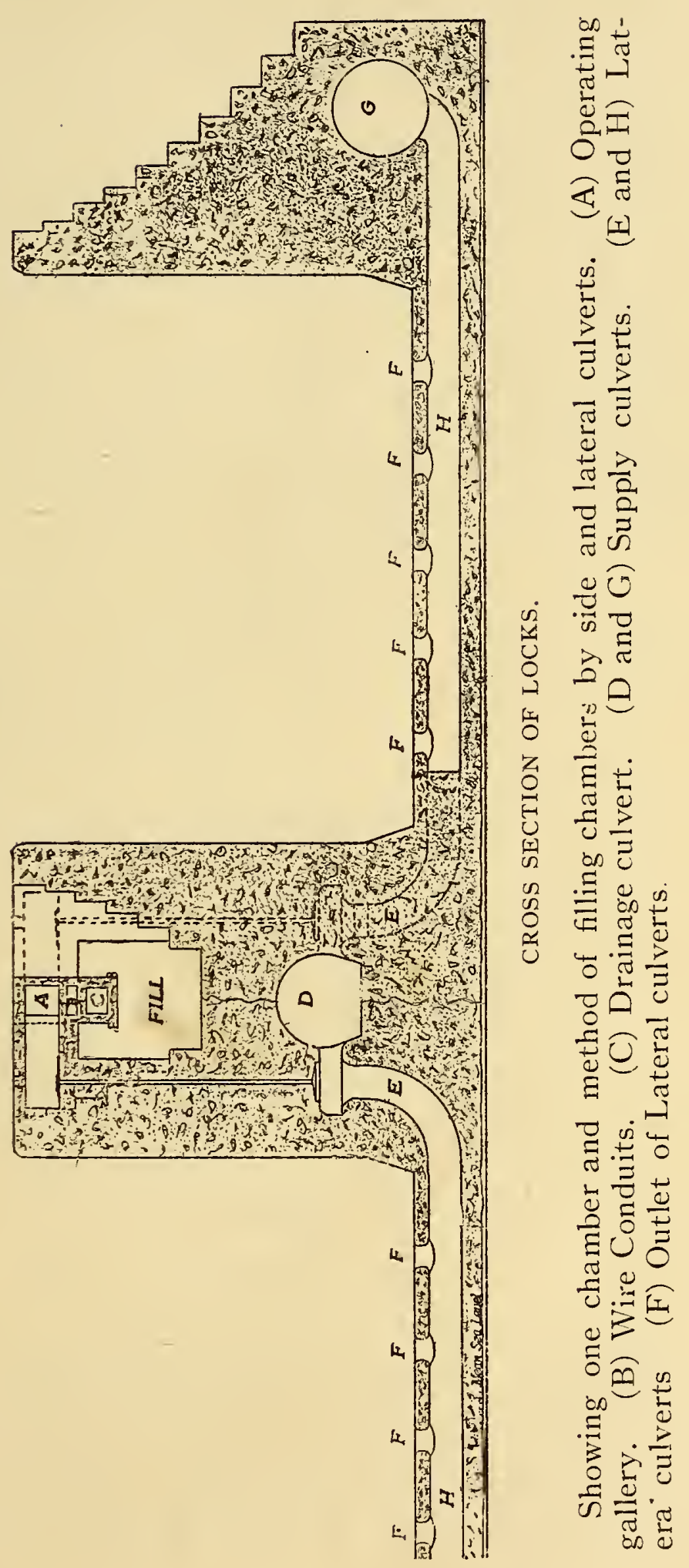


A cross section of the locks is shown herewith. The main features are the large culverts in the side and center walls through which water is conveyed from the lake level to any part of the locks. From the large culverts it is allowed to flow into or out of the chambers by culverts which open through wells in the floor. The flow in to and out of the locks is regulated by valves at the beginning of each culvert. The gates are of the miter type, built up of steel trusses covered with steel plate, forming a series of water-tight bulkheads. Each leaf is 65 feet long, 7 feet thick, and they vary in height from 47 feet to 82 feet, according to the position in the locks. The gates are set in two pairs, one pair being guard gates for use in case the other gates become dainaged or can not be operated, because of repairs to machinery, or from other causes. The arrangement of the gates in the locks is shown by the drawing herewith. In all there are $\mathbf{4 1}$ gates

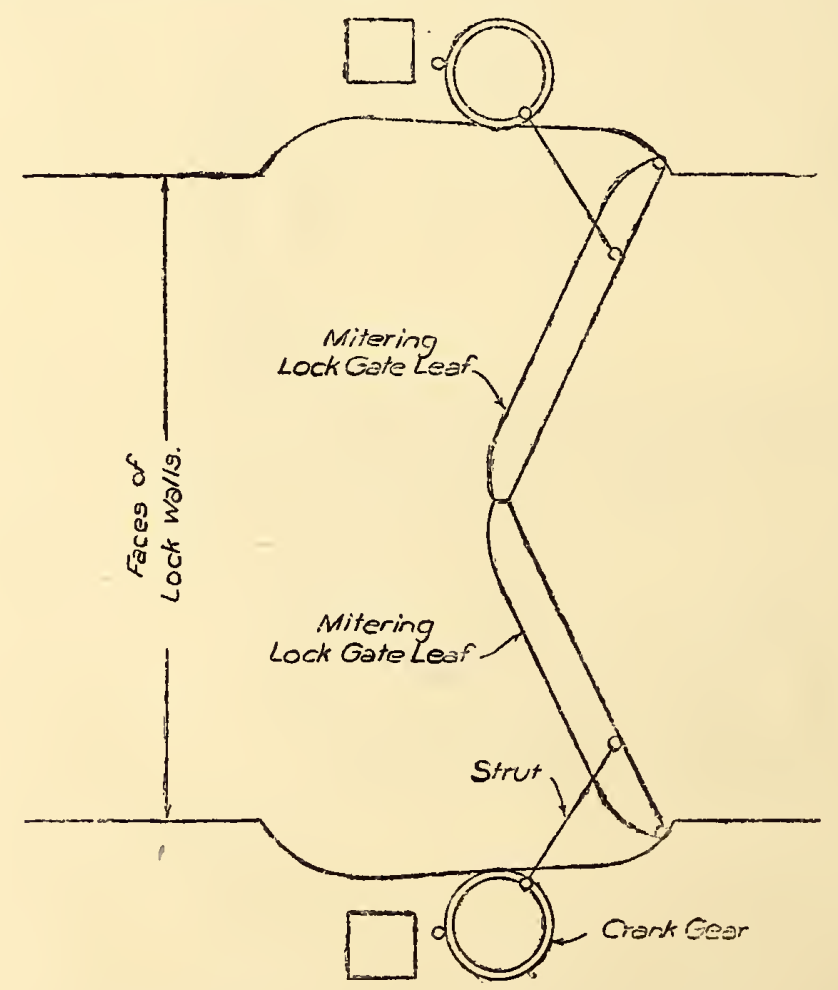

POSITION OF MITERING LOCK GATES.

of two leaves each. They are opened and closed by a steel rod attached to the top of each leaf and to the rim of a large wheel mounted on the lock wall. By rotating the wheel through an arc of 190 degrees the gate is opened or closed, just as one would reach out his arm and open orclose a door. (See pages 284 and 285.)

At both entrances to each flight of locks a fender chain is stretched across the channel to prevent ramming of the 
gates in case a ship should become unmanageable and enter the locks under its own steam. These chains are lowered to allow a ship in tow of the electric locomotives to pass over them into the locks. In case all the precautions to prevent accident to the gates fail, of if for any reason it is desirable to let the water out of the locks for repairs to the gates, an emergency dam of steel has been placed above each flight of locks, which can be swung across the channel, as a swing bridge is thrown over a waterway, to keep all water from the lake out of the locks. Caissons are also provided.

The gates, fender chain-pumps, emergency dams, towing locomotives, culvert valves, and all accessory machinery will be operated by electricity generated by water-

Operation power at the spillway of Gatun dam, and all of Locks. but the towing locomotives and emergency Material. dams will be controlled from a central station on the center wall from which all parts of the locks will be visible. The locks are constructed of concrete, of which it is estimated about $4,500,000$ cubic yards will be used. The proportions are one of cement, three of sand, and six of rock, and about one barrel of cement is used to each cubic yard. The thickness of the floor depends on the underlying material; in one part of Gatun Locks the floor is 23 feet thick and in another part only 3 feet. The walls are of uniform size; the side walls 50 feet wide at the floor of the locks and graduating to 8 feet at the top, and the center walls 60 feet wide at the floor with an operating tunnel for machinery and power cables at the top.

The locks at Gatun are built through the hill that forms the east abutment of the dam, and are on rock foundation.

The emplacement required six million cubic Gatun Locks. yards of excavation. They are six in number, three steps of twin locks; each step representing a lift of $28 \frac{1}{3}$ feet, a total lift of 85 feet. Rock was quarried and crushed at Porto Bello, and sand dug at Nombre de Dios, both historic ports a few miles east of Colon on the Caribbean. These materials were towed in barges to Gatun where they were assembled, and mixed with cement in a concrete plant of eight 2-cubic-yard mixers, that can turn out 400 cubic yards of concrete in an hour. The materials were unloaded at the docks on the French canal, by one set of aerial cableways, and the concrete placed by another, 
the latter extending over the lock site from opposing movable steel towers. There were four duplicate cableways in the concrete-placing plant and two duplicate and one simplex in the unloading plant. An auxiliary mixing plant of two 2-cubic-yard mixers was also used, and concrete from it

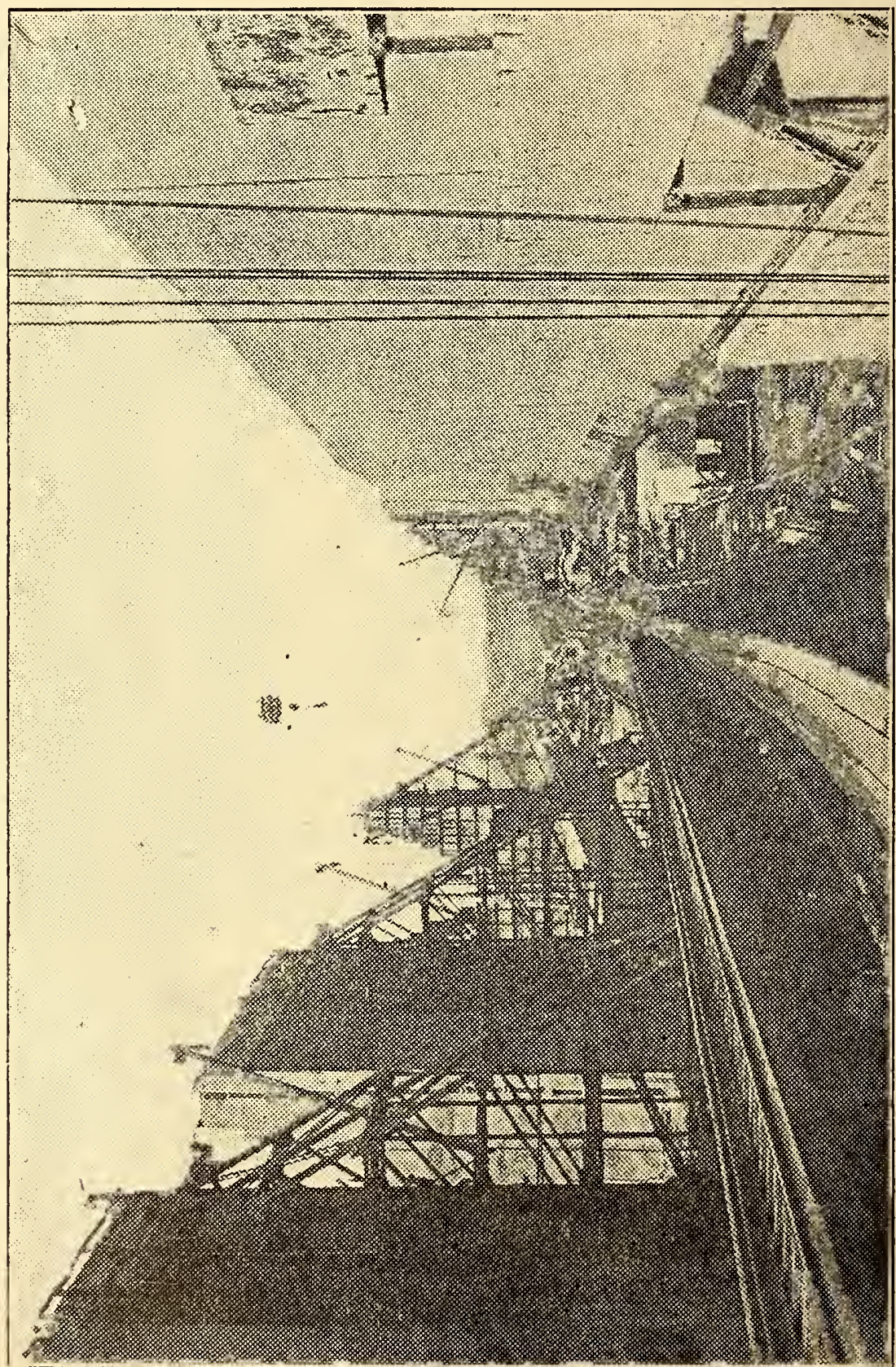

was delivered by cars on a narrow-gage railway running through the locks. In all $2,085,000$ cubic yards of concrete will be placed at Gatun. The estimated cost per yard was $\$ 7.75$ 
and when the work was only 60 per cent completed this had been reduced to $\$ 6.70$ a yard.

The locks at Pedro Miguel consist of a single flight or step of twin locks, two in all, by which a drop of 30 feet,

Miraflores Lake.

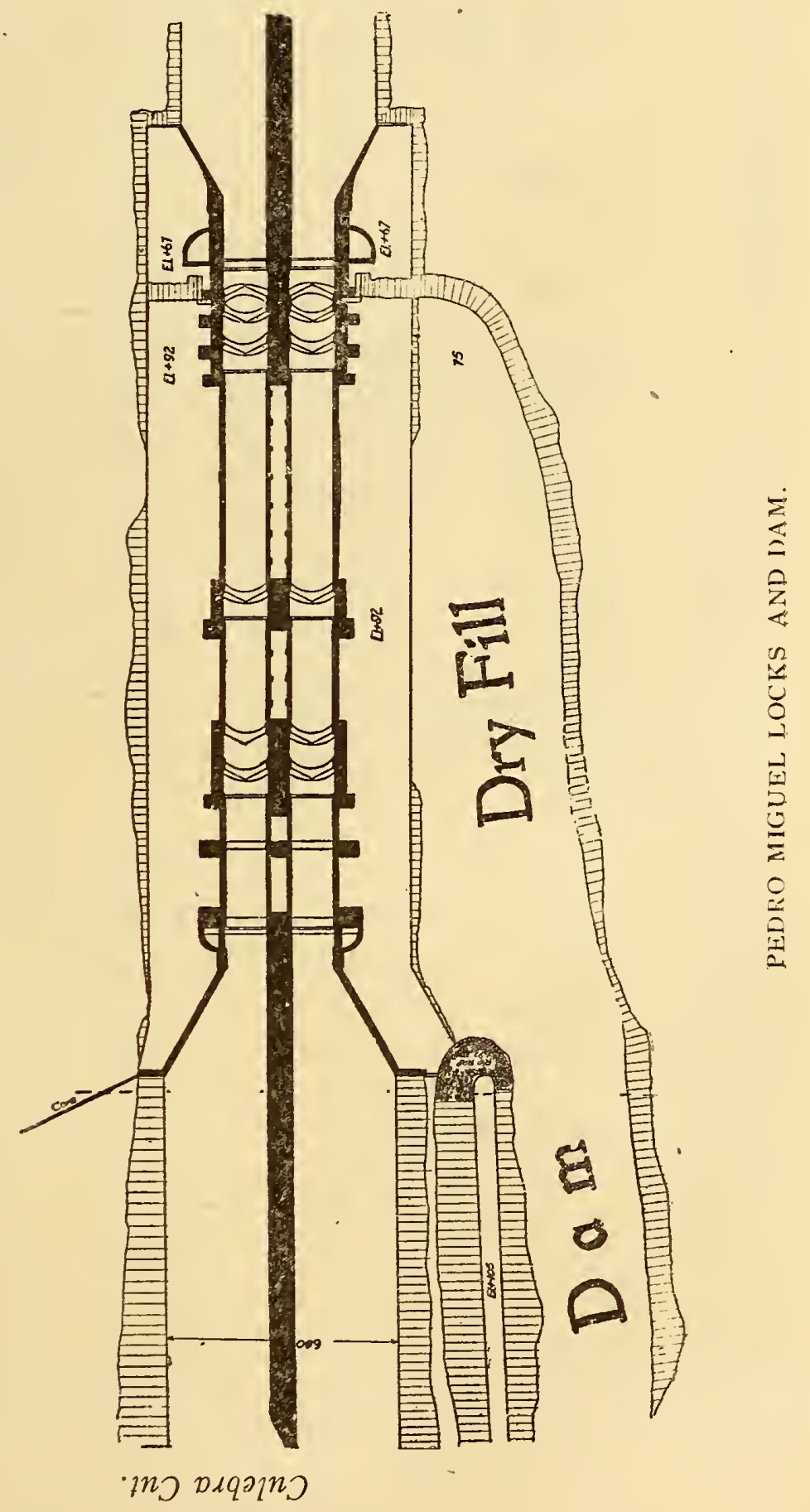


from Culebra Cut to Miraflores Lake, or a reverse lift, is

Pedro Miguel and Miraflores

Locks. accomplished. They are built through a hill, on rock, and 1,150,000 cubic yards of excavation were required for the emplacement. The total amount of concrete required is 837,500 cubic yards.

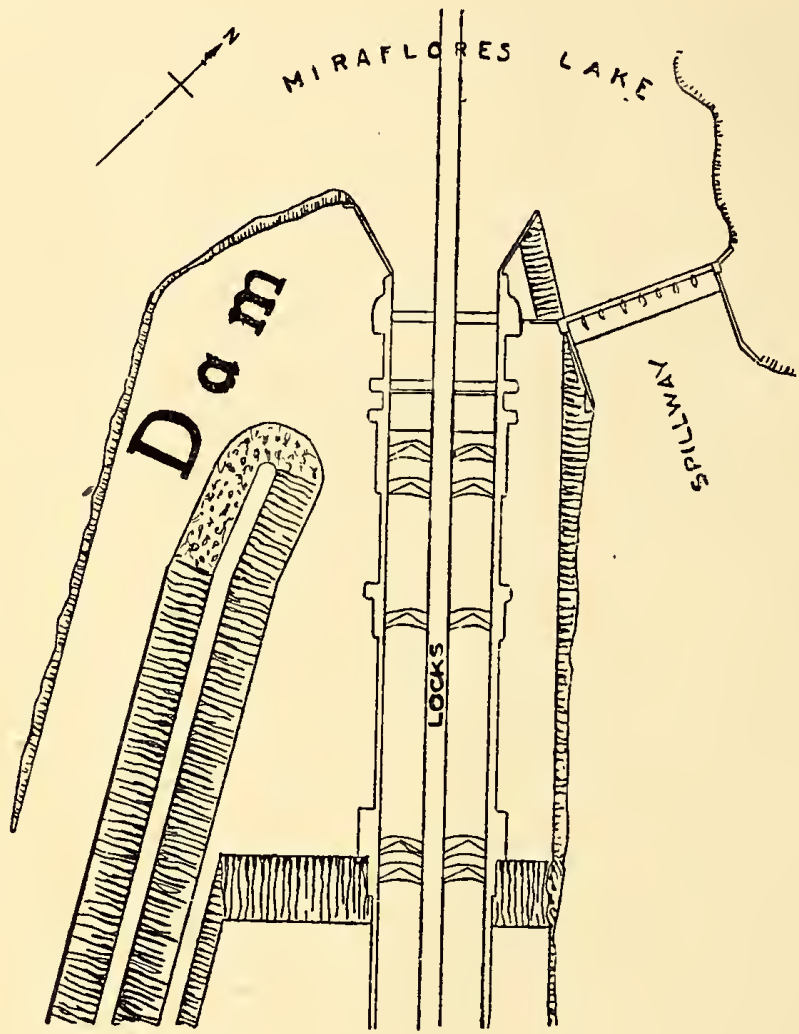

MIRAFLORES LOCKS, DAM, AND SPILLWAY.

Miraflores Locks are located in low ground, the river bed of the Rio Grande, and yet are on solid foundation. The emplacement required five million cubic yards of excavation. There are two flights or steps of twin locks, each step representing a lift of $27 \frac{1}{2}$ feet, a total lift of 55 feet. In all 1,362,000 cubic yards of concrete are required. At the lower or sea-level locks in this flight it has been necessary to anticipate the great differences in pressure due to the variation of 20 feet between high and low tide; and because of this difference these locks are the largest on the canal in point of depth, the maximum lift being nine feet more than in the sea-level locks at Gatun. The lower gates at Miraflores are 82 feet high.

The rock for concrete at Pedro Miguel and Miraflores is quarried and crushed at Ancon Hill, a few miles from the 
lock sites, and thesand is dredged at Chame beach a few miles west of the Pacific entrance to the Canal, whence it is carried in barges to Balboa and by train to the locks. The cost of concrete runs from $\$ \mathbf{4 . 5 0}$ to $\$ 6.00$ a cubic yard. At both locks the materials are taken from storage piles by cantilever cranes and mixed into concrete within the body of the cranes, whence it is hauled in cars to any part of the locks, to be placed by other cantilever cranes.

\section{Dams.}

There are three dams on the Canal-one at Gatun and one at Pedro Miguel, to hold the water of Gatun Lake at 85 feet above sea-level; and one at Miraflores to hold the water of Miraflores Lake at $\mathbf{5 5}$ feet above the sea.

The dam at Gatun, closing the valley of the Chagres River, extends from the hills on the east to those on the

Gatun Dam. west of the valley, is $1 \frac{1}{2}$ miles long, 115 feet high, and tapers from 2,500 feet broad at bottom to 100 feet at the top. The process of construction is to dump spoil from the canal excavation in two parallel ridges clear across the valley. Between these ridges suction dredges pump a light clay from the river bottoms nearby. This clay hardens as the water drains out, and forms a core that can not be penetrated by water. Halfway across the valley the dam encounters a small hill rising about 120 feet above sea level, and through this the spillway, an opening 280 feet wide, was located because it offered a rock foundation with little excavation. The purpose of the spillway is to regulate the surface of the water in the lake, and to this end sluice-gates are erected on a concrete foundation, by the opening of which 
the lake can be kept constantly at any given level, no matter how severe the rains may be in the lake region.

At the spillway there is an intake for water which will be passed through culverts to a power house below the regulating works, where it will turn turbines that will generate

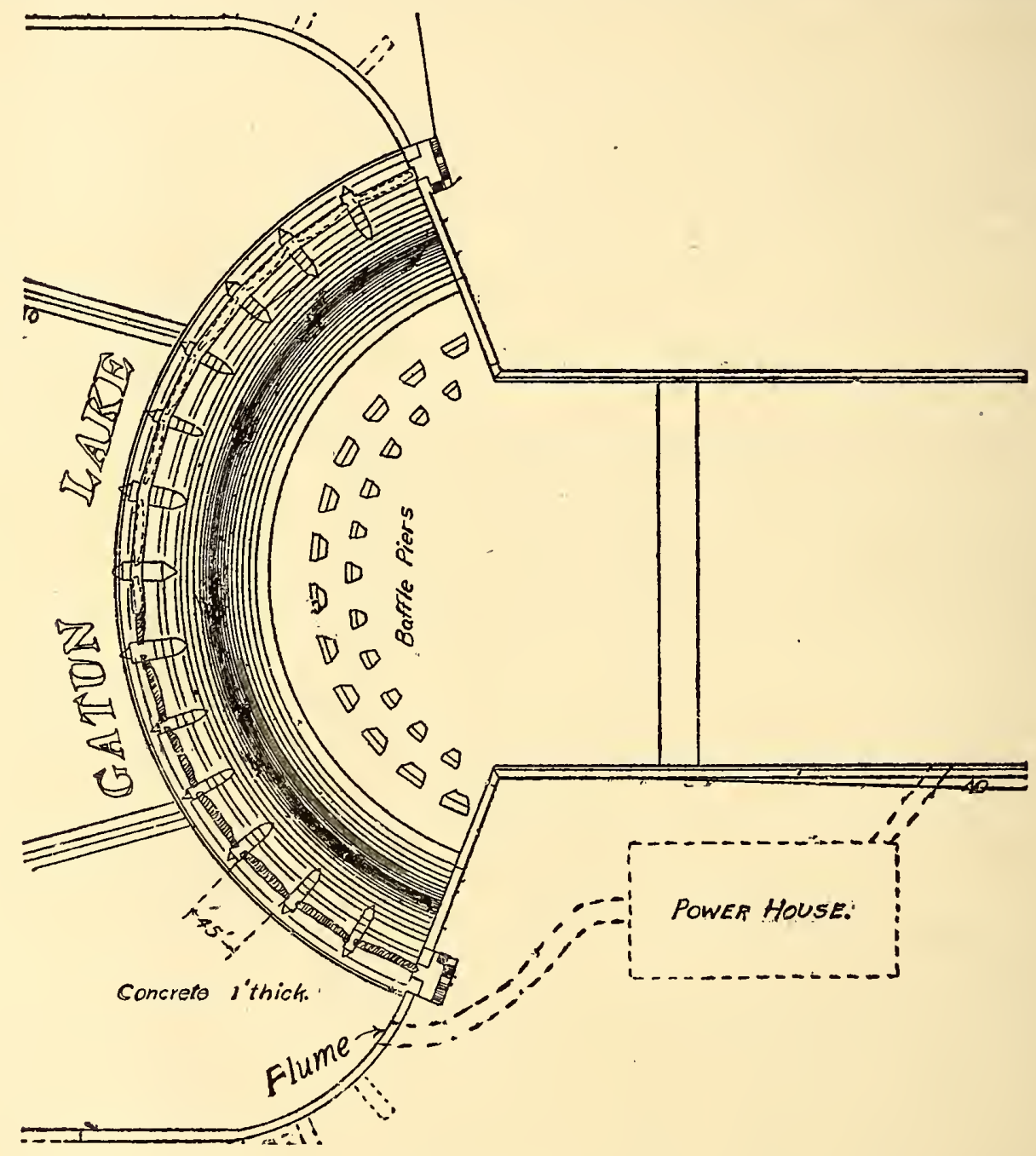

GATUN SPILLWAY.

Showing concrete dam with crest on a curve, Hydraulic Power Plant and Intake.

enough electricity to run all the machinery on the canal, operate the Panama Railroad, and light the whole Canal Zone.

The Pedro Miguel Dam is an earth-fill with puddle core, which extends from a hill west of Pedro Miguel Locks to the locks, and keeps the water of Gatun lake Pedro Miguel at a level of 85 feet above meantide. It is and Miraflores 1,700 feet long and the top is 105 feet above

Dams. sea level. A similar office is performed at 
the Miraflores Locks for the small Miraflores Lake by a dam 2,700 feet long, which joins the west hill to the locks, and a concrete wing wall 500 feet long extending from the locks to the east hill. On this wing wall are erected regulating gates like those in the spillway of Gatun Dam, and the wing wall is thus made to serve as both dam and spillway.

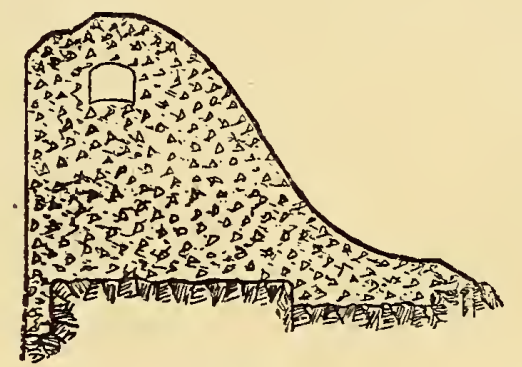

OGEE CURVE OF SPILLWAY DAMS.

The concrete dams across the spillways of Gatun and Miraflores. Dams are built on an ogee curve so that the force of the water will be broken as it rushes over.

\section{Gatun and Miraflores Lakes.}

Gatun Lake will extend from Gatun Dam to Pedro Miguel Locks, through Culebra Cut, a distance of 31 miles. on the center line of the canal. It is formed in the basin of the Chagres River by raising the surface of the river to 85 feet above sea level. The water, therefore, will extend into every part of the valley below that elevation, make islands of what are now hills, and deep inlets of the scores of streams that pour their waters into the river. Its area will be 164 square miles, and it will contain two hundred and six billion cubic feet of water when the surface is at 85 feet above sea level. Every rainy season enough water is poured into the Chagres basin to fill the lake one and a half times. At the close of each rainy season the surface of the lake will be at 87 feet above sea level, and evaporation, use of water for lockages and electric power, and waste may reduce it to the 85-foot level before the dry season (January to May) is over. Throughout the dry season there is a considerable run-off in the Chagres River, and freshets sometimes occur; so that there will be a constant addition to the great storage reservoir even during the driest months, probably enough to counterbalance the evaporation, which is estimated at about four feet a year. The ship channel through the 
lake from Gatun to Culebra Cut varies from 1,000 to 500 feet in width, and necessitated an excavation along the course of the Chagres River of about thirteen million cubic yards.

Miraflores Lake will be a pond about 2 miles in area, in which will collect water used in lockages at Pedro Miguel Locks and the run-off of the Cocoli River. Its surface will be at 55 feet above sea level. The ship channel through this lake will be 500 feet wide and a little over one mile long.

\section{Culebra Cut.}

The part of the Panama Canal on which most work has been done, and which will be the last completed, is the cut through the hills of the continental divide, known as "Culebra Cut." This section is 9 miles long, extending from the point where, in its descent to the sea, the Chagres River turns at a right angle from an easterly course to one almost exactly north, to Pedro Miguel Locks where the line of the canal runs into the valley of the Rio Grande. Excavation was begun here by the French on January ${ }^{\circ} 20$, 1882 , and has continued with only three years' interruption (1888-1891) up to the present time. The Bulletin $d u$ Canal Interoceanique (issued in Paris by the old French company) published the following cable message from Panama, under date of January 20, in its issue of February 1, 1882:

"The first work on the great cut of the maritime canal was formally inaugurated to-day at Empire in the presence of the dignitaries of the state, the leading citizens of the city, and the great assemblage of the people. The first locomotive has arrived at the newly opened excavation. The city of Panama is celebrating the event with a grand fete."

The French were working in Culebra Cut on May 4, 1904, with 700 men, when the United States Government assumed control. In this section they had excavated about nineteen million cubic yards of earth and rock useful in the present canal, leaving eighty-four million yards to be excavated under the American regime.

The digging here, as at other points, is done by steamshovels, and it is here that the superiority of modern methods of excavation has been shown.

Steam-Shovels. Forty-five steam-shovels dig, and load upon cars, 60,000 cubic yards of material each 8hour day. This quantity is said to represent about 120,000 two-horse wagon-loads. Trains of 20 cars, each car hold- 
ing 20 cubic yards of rock and earth, hauled by 100-ton locomotives, carry away the spoil to be utilized in the dam at Gatun, the breakwater at the Pacific entrance, the new line of the Panama Railrcad, or to dumps where it is

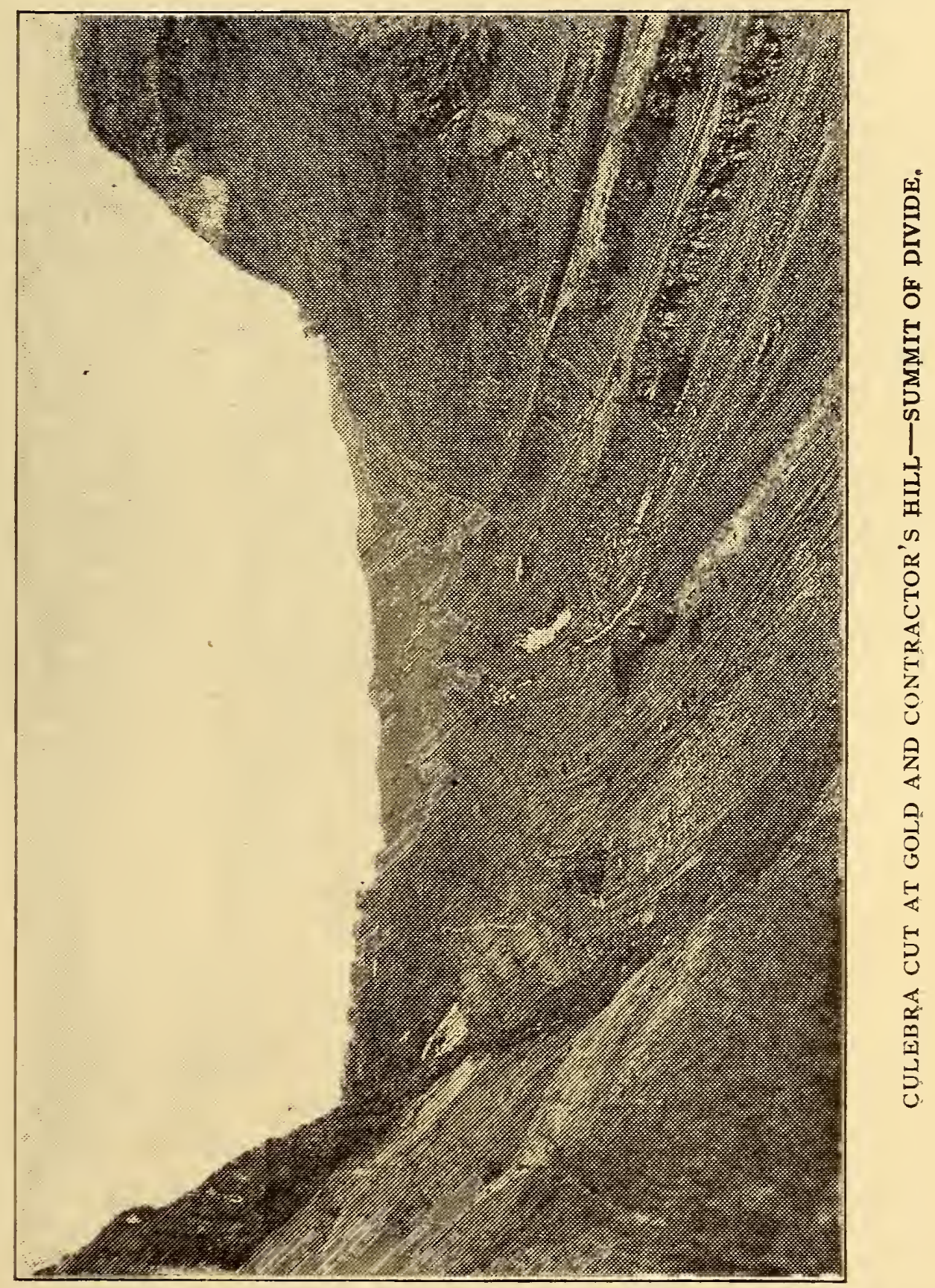

merely wasted. The method of work is to drill holes in the rock, fill them with dynamite, and then shatter the material into such fragments as a steam-shovel can handle. Four main lines of railroad track with numerous spurs enable 
an endless chain of trains to pass through the cut, to $p$ beside shovels for their load, and when loaded pass out to the dumps.

The lor.g trcrch is kept dry by two methods. Diversion ditches $c n$ either side prevent water from the side hills from flowing into the excavation. The dig-

Drainage. girg is carried on from a center point or summit on a downward slope toward either end of the cut. A center drainage ditch carries the water by gravity to a sump at the north end, whence it is pumped over a barrier into the Chagres River; and to Pedro Miguel Locks at the south end, whence it flows by gravity through the locks into the old channel of the Rio Grande.

A troublesome but not serious feature of the work are the slides from both banks, 22 in number, and in amount about twenty million cubic yards. Masses of

Slides. earth and rock, from which the supporting toe has been removed by excavation, slide into the prism of the canal, and must be dug out. On account of these slides it may be necessary to excavate the last ten feet of the rock in Culebra Cut by dredges, after the canal is opened to navigation; but this will not be allowed to prevent the opening in 1913 , although it may retard the actual completion. There are no ships in the Panama trade that could not use the canal with a minimum depth of 35 feet of water, and none in the American Navy that might not be taken through with perfect safety.

\section{Supplies and Equipment.}

Practically all the supplies and equipment in use on the Canal are purchased in the United States, because a law, passed by the Congress in 1905, makes home purchases obligatory, unless the President should deem prices asked by United States manufacturers exorbitant in comparison with those quoted in foreign countries. This law has had the effect of keeping American manufacturers within bounds in their bids. In only two cases has it militated against them-one in the purchase of the largest dredge in use on the Canal, which was built in Scotland at 50 per cent of the price asked by the only American bidder; and the other in the purchase of Mannesman tubes for the stems of valves in the lock culverts, after the only manufacturer of this class of material in the United States had arbitrarily increased the price with direct reference to the Canal work. 
Under the law, any article or supplies of a value not exceeding $\$ 10,000$ may be purchased in the open market without advertisement or bid. In practice this privilege is seldom used, and nearly all equipment and supilies are purchased on competitive bid, after due advertisement. The award must be made to the "lowest responsible bidder." This system does not always procure the best machines or materials, but it is the most economical in the end; because any other would be a constant nuisance by giving endless opportunity for charges of unfairness by bidders, and of dishonesty by a vigilant and not overscrupulous sensational press.

In making purchases the methods long used by the United States Army, Navy, and other Government departments are followed. Since 1907 the administration has been able to determine from year to year about what amount of materials and supplies is necessary during the following year; and standard articles are purchased in sufficient quantities to last twelve months. The contract entered into obligates the contractor to furnish more of a given article up to 50 per cent, in case the Canal authorities so wish, and absolves the Canal Commission from purchasing within a certain per cent (usually 20) of the estimated amount required. Inspection of materials is made by the technologic bureaus of the United States Government, or, in case such knowledge is not required, by inspectors in the Canal service. Only materials that comply with specifications are accepted. All supplies are handled by the Quartermater's Department, Colonel G. A. Devol, Ghief Quartermaster; Capt. R. E. Wood, Assistant Ghief Quartermaster; Capt. C. Nixon, Depot Quartermaster.

It is difficult to find terms that will convey a true impression of magnitude where one is dealing with such quantities as are required in the canal work. One easily senses a barrel of cement, less readily a thousand barrels; but $4,500,000$ barrels are beyond visualization. Broadly speaking, 3,500 barrels of cement were required every day while the lock building was at its height; and the delivery of this material from New York took all the time of two 10thousand-ton ships, and several smaller ones aggregating ten thousand additional tons. So with steel, dynamite, and other supplies; the amounts are so large as to mean little, because they baffle familiar comparison. In 1910, the year when the work was at its height, there were purchased 350,000 tons of materials, valued at $\$ 10,000,000$. 
The dry excavation is done by steam-shovel and the wet by dredges of various types. When dry excavation was at its highest point, in 1910,560 drills were Equipment in used in drilling the material for blasting, Canal Service. 100 steam-shovels dug the earth and rock and loaded it upon cars, 3,600 cars carried it to the dumps, and 158 modern locomotives hauled trains. In addition to these there were 700 cars in general service, and 1,470 freight cars on the Panama Railroad, 112 old French locomotives, 32 narrow-gage locomotives, and 12 electric locomotives in use. Miscellaneous equipment for the dry excavation consists of 25 machines for spreading spoil on the dumps, 10 machines for shifting track, 30 for unloading spoil from the large flat cars, 57 locomotive cranes, and 20 pile drivers.

In the wet excavation there are in use 7 ladder or elevator-dredges left by the French, one modern ladder-dredge, 3 dipper-dredges, 2 sea-going suction-dredges, and 1 clamshell dredge, 1 subaqueous rock-breaker, 11 self-propelling barges (clapets) left by the French, 2 drilling barges, 1 piledriver, 14 launches; and, in the wet-excavation and rockand-sand services, 12 tugs, 1 tow-boat, 1 crane-boat.

This equipment is supplemented by that used in mixing and laying concrete in the locks, which is referred to under the section on Locks.

Among the manufacturers supplying materials are the following:

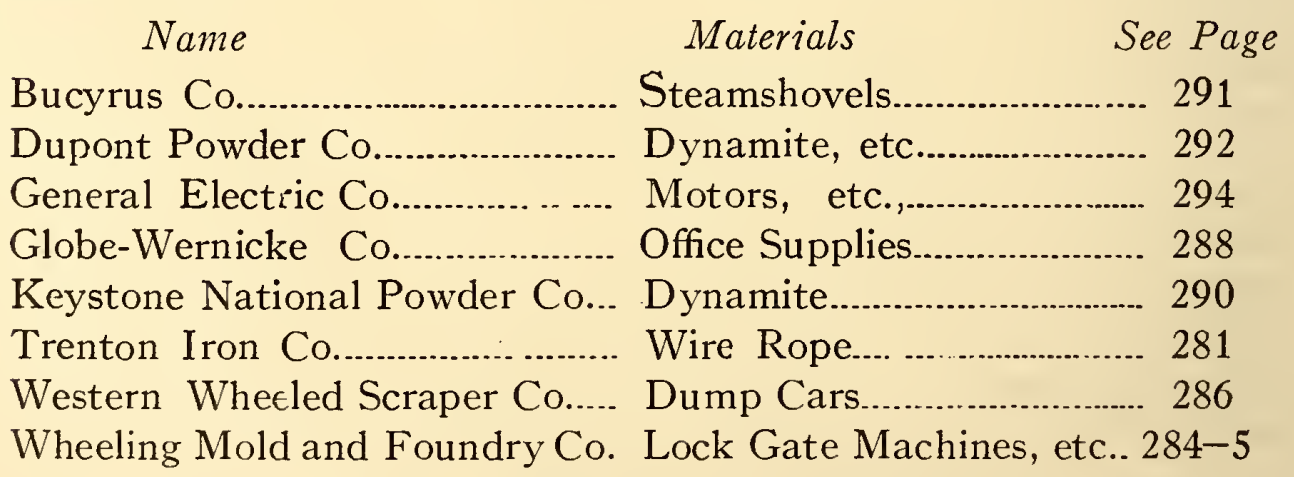

\section{Commissaries and Messes.}

The United States Government is in the department store business on the Isthmus, runs hotels, has a cold storage and manufacturing plant, and in general carries on a great provision and clothing establishment. It does this work so much better and more economically than similar enterprises are conducted in the United States, that the time 
one spends in investigating this branch of the canal work will be profitable as well as interesting. The men who manage this branch are Lieut.-Col. E. T. Wilson, Chief Subsistence Officer; Capt. F. O. Whitlock, Assistant Subsistence Officer; Mr. John Burke, Manager of Commissaries, and Mr. W. F. Shipley, Chief Clerk.

The subsistence branch has the work of feeding all the employes not living in family quarters. There are three classes of such employes and a separate system Mess Halls. of messes is maintained for each-(1) hotels for white Americans; (2) mess halls for European laborers; (3) kitchens for negro laborers. The hotels are really mess halls, because no sleeping accommodations may be obtained by transients. They consist of a large room set with tables, a balcony arranged in the same way, and a kitchen and ice box. The meals cost 30 cents each to employes and 50 cents to transients. They are good meals for the price and the service is good, considering that most people want their food in a hurry and must be accommodated. The messes for Spanish laborers are conducted in halls, and the laborers sit down at long tables upon which the food is placed with a great clatter. Meals cost 40 cents for three, and they are usually good. Negro laborers get their food in pans or pails at the mess kitchens, and three meals or rations cost 27 cents. There are 19 hotels, 16 messes, and 14 laborers' kitchens. About 3,000 employes eat at the hotels, 3,000 at the messes, and 6,000 get food from the kitchens. The negro laborers do not patronize the kitchens regularly because no provision is made for service, the food being dished out to be eaten elsewhere. The Spanish laborers who do not eat at the mess halls patronize some cantina run by one of their own people, where they can get wine, and take as much time as they please for their meals. The subsistence branch maintains itself and pays a small profit. See also "A Canal Builder's Village" and "Social Conditions and Forces."

The present commissary system is an outgrowth of the old railroad commissary store. It maintains an ice plant where 100 tons of ice are made daily, a bakery

Commissary. which produces six million pounds of bread a year, an ice cream factory, a cold storage plant, meat cutting shop, soup factory, corned beef plant, coffee roaster, butter prin tery, and laundry. Thereare 18 retail stores, 
of the character of a country general store, situated in various Canal Zone villages, and they are supplied with stocks of food and clothing from the warehouses at Cristobal. The total annual business amounts to about six million dollars, and 90 per cent of this money is spent in the United States, 5 per cent in Panama, and 5 per cent in Europe.

For five years the Commissary has succeeded to the extent that it has paid an annual dividend, paid living wages to its employes, and sold meat, bread, butter, ice, coffee, sugar, shoes, underwear, and other necessaries at a lower price than they could be bought at retail in the United States. It handles no "cheap" stuff, works off no bad foods or shoddy clothing, strives always to "give the money's worth," and it usually succeeds. It is the most striking instance in history of the economy of collective effort in meeting the common problem of "how to live." 
Terminal, Repair, and Supply Facilities.

The terminal facilities now under construction provide for a system of piers at both entrances of the Canal, with appliances for rapid handling of cargo. It should be remembered that a large amount of t:-e trade by way of the Canal will not be through traffic; that is. ships from New York, New Orleans, Liverpool, and other ports, will touch at Colon, unload part of their cargo, and then sail to other ports on the Atlantic seaboard. Ships for the west coast of the Americas and for the Orient will stop at the docks, pick up this freight, and carry it to its destination.

At the Atlantic entrance a mole has been constructed from the village of Cristobal, at right angles to the Canal channel for a distance of 3,500 feet. ProAtlantic jecting from this mole inland, almost parallel Entrance. to the Canal, will be the terminal docks. A quay-wall and two piers are under construction; the layout is such that, as soon as the trade demands it, three more piers can be built. The piers are 1,000 feet long and the slips between them 300 feet wide, so that two 1,000 foot ships may dock at one time without entering the Canal itself. The direction of the mole is such, with relation to the Canal entrance and the breakwater which juts out from Toro Point, that it will aid materially in breaking the force of the heavy seas which the violent northers of November, December, and January, pile up in Colon harbor. It is believed that this method of constructing the docks will make unnecessary the construction of the east breakwater, contemplated in the original plans of the Canal.

At the Atlantic entrance in close proximity to the docks will te a coaling plant, from which the Government will supply coal to its own vessels and to such

Supply commercial vessels as may require it. It is

Defot proposed to maintain the present commissary plant at Cristobal as a base of supplies for the Army and Navy, and it may be necessary even to enlarge this supply depot.

At the Pacific entrance the terminal docks will be at Balboa, about five miles inland from the beginning of the Canal. A quay-wall 2,000 feet long has been Pacific constructed along the edge of the ship basin, Entrance and it will be supplied with machinery for the rapid handling of lumber and materials of 
this class. Here, also, ships will tie up while minor repairs are in progress at the marine shops. North of the quay-wall will be a series of piers, similar to those at the Atlantic entrance, jutting out from the mainland as the fingers stick out from the hand. Each of these will be 1,000 feet long, and the slips between will be 300 feet, thus allowing two 1,000 -foot ships to use each dock at one time. The piers will be equipped with cranes especially adapted to the rise and fall of the tide, for the variation between high and low tide at the Pacific entrance is as high as twenty feet. Any ship that can use the Canal can likewise use the docks at the Pacific entrance.

Alongside the terminal quay and piers will be a dry dock capable of taking any ship that can use the Canal. It will be situated behind Sosa Hill in a position

Dry Dock where the fire from an enemy's guns can not and Shops. reach it. Between the dry dock and the wharves will be marine shops in which repairs to Government vessels, and to such commercial ships as may require them, will be made by the Government.

It is the avowed intention of the Government to place its terminal, coaling, and repair facilities at the disposal of commercial vessels, because it is believed that in no other way can a monopoly of the use of the Canal by powerful interests in the United States and elsewhere be prevented. For instance, if any private interest controlled the coaling facilities or the repair shops, commercial vessels competing with the vessels of "the interests" would be under a serious handicap. On the other hand, it is not the policy of the Government to prevent private companies from maintaining coaling places or marine shops at either entrance of the Canal, provided they wish to do so, and there are evidences that such facilities will be maintained by private companies.

\section{The Cost.}

It is estimated that the cost of the Canal ready for use will be $\$ 375,20,000$. This estimate was made in October, 1908, and is the only one based on actual experience in the developed work. In 1906 the minority of the Board of Consulting Engineers, who advised the construction of a lock canal, placed the cost of construction, engineering, and administration, at $\$ 139,705,200$, and the same items 
were estimated in 1908 at $\$ 297,766,000$. The items of the es timate of 1908 are as follows:

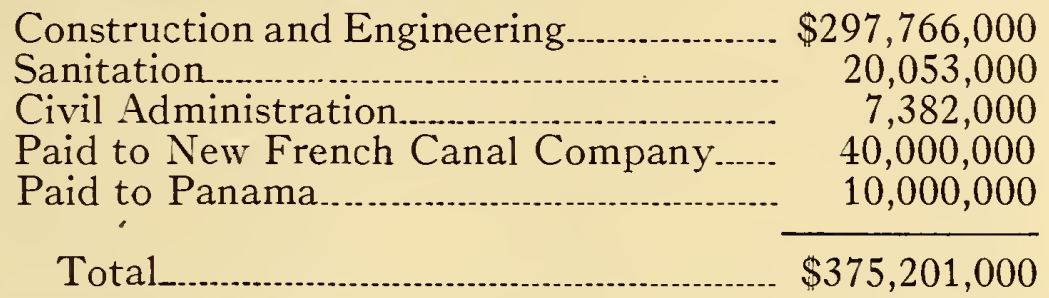

Reimbursements to Treasury, not including salvage from present plant, $\$ 15,000,000$.

It is apparent, therefore, that the estimated cost, less reimbursements and salvage, will be about $\$ 358,000,000$.

Since 1908 the force has increased so much in efficiency, that unit costs have decreased, and it now seems probable that the $\$ 358,000,000$ will cover not only the items mentioned above, but also the $\$ \mathbf{\$ 2 , 0 0 0 , 0 0 0}$ estimated for fortifications.

Distances by Way of Panama.

Tables of distances from leading ports to other ports by way of the Panama Canal follow:

To PANAMA TO VARIOUS POINTS.

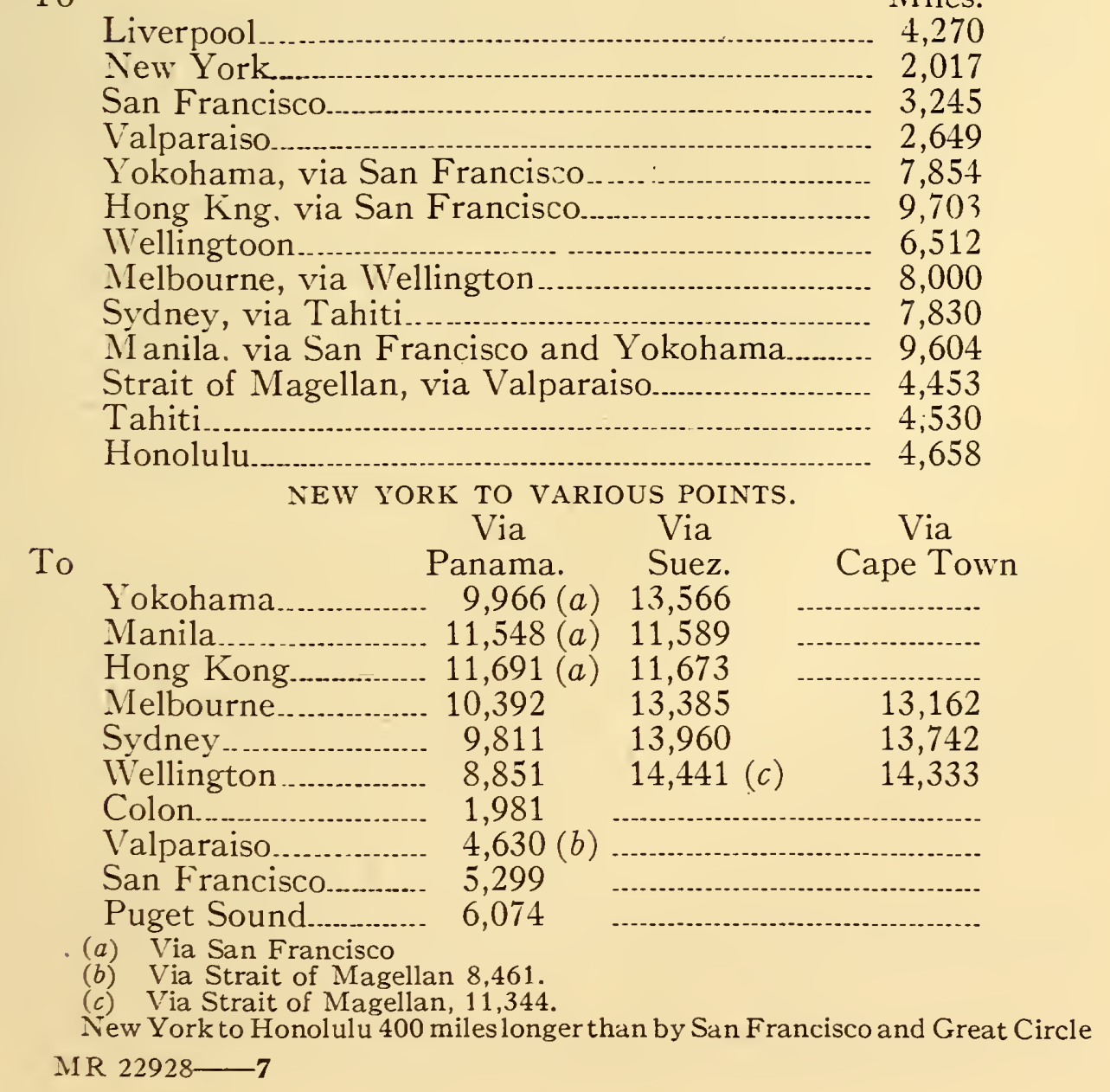




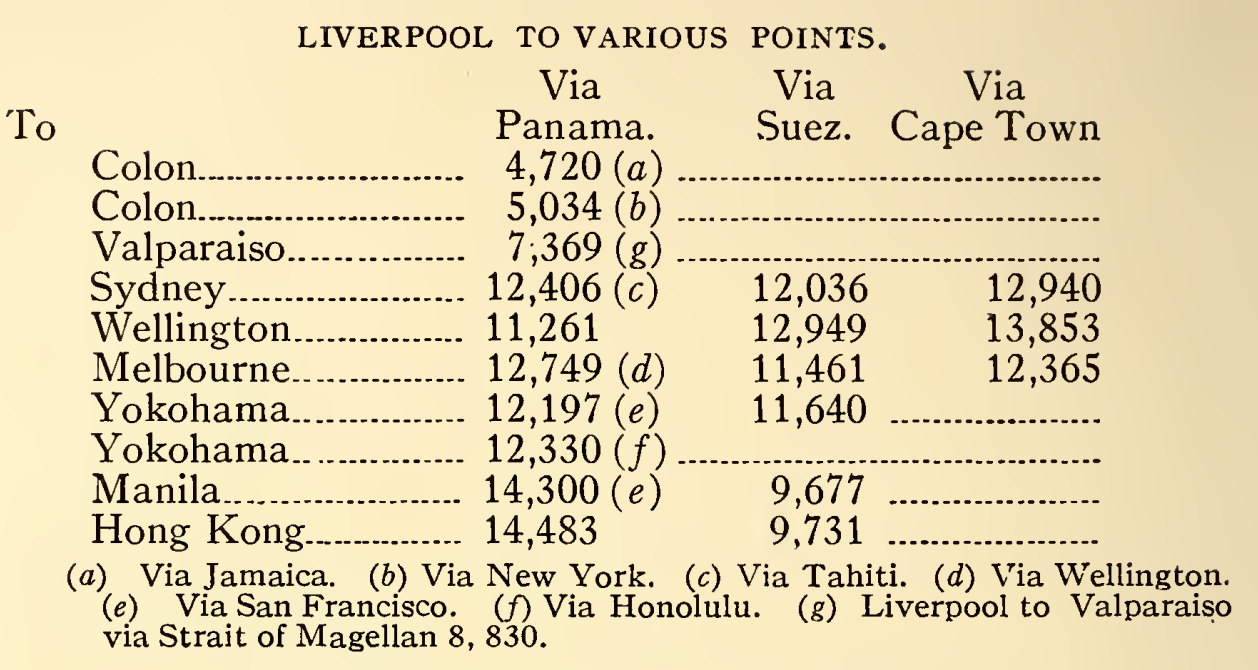

Fortification and Neutralization.

Little is known on the isthmus about the fortifications which are to guard the entrances to the Canal, because, here where the construction work is in progress, a commendable secrecy is maintained in regard to the forts. The forts at the Atlantic entrance will be at Toro Point and Margarita Island, guarding, respectively, the west and east sides of the Canal. At the Pacific entrance they will be on the islands of Flamenco, Perico, and Naos in Panama Bay; and on the mainland at Balboa, points from which they command the entrance at this end. They have been named as follows:

The Reservations at the Pacific Entrance-Fort Grant and Fort Amador, the first in honor of Gen. Ulysses S. Grant, U. S: A., President of the United States from 1869 to 1877 , who died on July 23, 1885; and the second in

Names of honor of Dr. Manuel Amador Guerrero, first Forts. President of the Republic of Panama, who died on May 2, 1909. The Reservations at the Atlantic terminus-Fort Sherman, Fort Randolph, and Fort de Lesseps, named in honor of Gen. William T. Sherman, U. S. A., who died February 14, 1891; Maj. Gen. Wallace F. Randolph, U. S. A., who died September 9, 1910; and Count Ferdinand de Lesseps, promoter of the Panama Canal, who died December 7, 1894.

FORT GRANT MILITARY RESERVATION.

Battery Newton, in honor of Maj. Gen. John Newton, U. S. Volunteers (Brigadier General, Chief of Engineers, U. S. A.), who died May 1, 1895.

Battery Merritt, in honor of Maj. Gen. Wesley Merritt, U. S. A., who died December 3, 1910 . 
Battery Warren, in honor of Maj. Gen. Gouverneur $\mathbf{K}$. Warren, U. S. Volunteers (Lieutenant Colonel, Corps of Engineers, U. S. A.), who died August 8, 1882.

Battery Buell, in honor of Maj. Gen. Don Carlos Buell, U. S. Volunteers (Colone1, Assistant Adjutant General U. S. A.), who died November 19, 1898.

Battery Burnside, in honor of Maj. Gen. Ambrose E. Burnside, U. S. Voluṇteers (First Lieutenant, Third U. S. Artillery), who died September 13, 1881.

Battery Parke, in honor of Maj. Gen. John G. Parke, U. S. Volunteers (Colonel, Corps of Engineers, U. S. A.), who died December 16, 1900.

FORT AMADOR MILITARY RESERVATION.

Battery Smith, in honor of Maj. Gen. Charles F. Smith, U. S. Volunteers (Colonel, Third U. S. Infantry), who died April 25, 1862.

FORT SIERMAN MILITARY RESERVATION.

Battery Howard, in honor of Maj. Gen. Oliver O. Howard, U. S. A., who died October 26, 1909.

Battery Stanley, in honor of Maj. Gen. David S. Stanley, U. S. Volunteers (Brigadier General, U. S. A.), who died March 13, 1902.

Battery Mower, in honor of Maj. Gen. Joseph A. Mower, U. S. Volunteers (Colonel, Twenty-fifth Infantry), who died January 6, 1870.

Battery Kilpatrick, in honor of Maj. Gen. Judson Kilpatrick, U. S. Volunteers (Captain, First Artillery), who died December 2, 1881.

FORT RANDOLPH MILITARY RESERVATION.

Battery Tidball, in honor of Brig. Gen. John G. Tidball, U. S. A., who died May 15, 1906.

Battery Webb, in honor of Brevet Maj. Gen. Alexander S. Webb, U. S. A. (Lieutenant Colonel, 44 th U. S. Infantry), who died February 12, 1911.

Battery Weed, in honor cf Brig. Gen. Stephen H. Weed, U. S. Volunteers (Captain, 5th U. S. Artillery), who was. killed in action, July 2, 1863, at Gettysburg, Pa.

FORT DELESSEPS MILITARY RESERVATION.

Battery Morgan, in honor of Brig. Gen. Charles H. Morgan, U. S. Volunteers (Major, 4th Artillery), who died December 20,1875 .

The right of the United States to fortify the Canal was. 
seriously questioned at one time by statesmen and publicists because of a clause contained in the ClayRight to ton-Bulwer Treaty of April 19, 1850, providing Fortify that neither the United States nor the United Kingdom would fortify the Canal or exercise any dominion over any part of Central America. In the Hay-Pauncefote Treaty of November 18, 1901, it is provided that the first Treaty is superseded without impairing the general principles of neutralization as established in Article 8 of that Convention. The Treaty further provides:

"It is agreed that the Canal may be constructed under the auspices of the Government of the United States, either directly at its own cost, or by gift or loan of money to individuals or corporations, or through subsaription to or purchase of stock or shares, and that, subject to the provisions of the present Treaty, the said Government shall have and enjoy all the rights incident to such construction, as well as the exclusive right of providing for the regulation and management of the canal. **** The canal shall never be blockaded, nor shall any right of war be exercised nor any act of hostility be committed within it. The United States, however, shall be at liberty to maintain such military police along the canal as may be necessary to protect it against lawlessness and disorder."

The question of fortification is no longer an open one because the United Kingdom, the only nation that had a right to object, has acquiesced in the erection of forts. The ground taken by the United States was, that in order to insure the neutrality of the Canal, as it is bound to do by Treaty, it was necessary to have such forts and naval bases at both entrances as would enable it to repel the attack of an enemy, and to insure the use of the Canal by belligerents in accordance with the rules laid down. (See Treaties.)

The forts as planned are in a position to protect not only the entrances of the Canal, but to make it practically impossible for the ships of an enemy to deOther Militarystroy or injure the only vulnerable part of

Protection. the waterway-that is, the locks. Gatun Locks are seven miles inland from the forts at the Atlantic entrance, and Miraflores Locks nine miles inland from the ou termost fortification at the Pacific entrance.

In addition to the forts which will guard either entrance, a.system of inland defenses for the locks has been agreed upon. The headquarters for the Army, Navy, and Marine Corps on the isthmus will be at the Pacific entrance of the Canal, but posts will be maintained elsewhere, including the Atlantic entrance, the locks, and probably at a point along Culebra Gut, opposite Gulebra. 


\section{Panama Railroad}

The Panama Railroad is owned by the United States, but the form of a private corporation is maintained because it enables the railway to do business more promptly than if all its acts were scrutinized by the Auditor and the Comptroller of the Treasury. Each of the board of directors holds one share of stock, but this must be turned over at any time on demand of the Secretary of the Treasury. The railroad is conducted by a railroad man of 25 years' experience, Mr. J. A. Smith, the General Superintendent, and the steamship line by Mr. E. A. Drake, first Vice President, whose office is in New York, and who has spent his business life in the service of the company. Col. Geo. W. Goethals is President. This first railroad to be owned by the United States pays dividends, and is run on business principles. Although it has been a Government railroad eight years, under three distinct Canal administrations, it has not yet attracted to itself or had inflicted upon it the "political favorites" that we are commonly told would run the trains on Government railroads.

The first concession for a railroad across the is thmus was granted to a Frenchman in 1847 , but he failed to raise the money necessary to build the road. In December, 1848, a concession was granted by Colombia to William H. Aspinwall, Henry Chauncey, and John L. Stephens, Americans, and this was modified to the advantage of the company on April 15, 1850, and again on August 16, 1867. The concessionaires had in view the handling of the immigrant trade bound for California and Oregon, recently opened to settlement, and Aspinwall had already (1848) established a steamship service between San Francisco and Panama. The discovery of gold in California made it possible to raise the money to begin the undertaking.

At that time railroad building was in its infancy, and the project of a line 50 miles long across a notoriously unhealthful country was regarded as a distinct hazard. Money ran low in 1851 and the progress of the work was not encourag- 
ing, as the line had been completed only to Gatun, seven miles inland. In November of that year a ship unable to land its passengers at the mouth of the Ghagres, as was cus tomary for the transit, landed them at Colon, and at once the railroad came into use. The rates charged were high, but the service, as far as the trains went, was prompt compared with the canoes on the river. From 1852 to the present time the road has paid a dividend of from 3 to 61 per cent annually.

Glearing was begun in May, 1850, and the first train crossed the continent on January 28,1855 . As originally constructed the line was 47 miles, 3,020 feet, and the summit was at 263 feet above mean sea level. From the beginning the passenger and freight trade were heavy, as the road was used by all the west coast of North and South America, and, until an arbitrary decision of the management drove them from the trade (1868), there were several ships carrying European freight from Panama to the Orient. In 1869 the railroad across the United States was completed and thus a considerable amount of freight and almost all the passenger traffic for California and Oregon were diverted. Notwithstanding, the road continued to pay good dividends.

In August, 1881, the French canal company purchased 68,887 of the 70,000 shares at $\$ 291$ a share. The railroad was absolutely necessary in the canal construction. When the United States completed its purchase of the French rights (May 4, 1904) it came into possession of the 68,887 shares of railroad stock, and by private purchase acquired the balance.

The heavy equipment purchased for the American Canal work made it necessary to relay the road with 80 -pound rail, double track 40 miles of it, and otherwise improve it. Since 1904 the equipment has been renewed and it now has 100-ton oil-burning locomotives, large and comfortable day coaches, parlor cars, and 40-ton freight cars.

Its commercial usefulness has been somewhat handicapped by the Canal work, because all considerations are made secondary to this. At present it cannot handle all the freight between the east and west coasts of the United States that could be procured, but it does transfer an average of 35,000 tons of commercial freight a month. This is about half of the total freight carried, the balance being for the canal and the railroad. 
The canal construction made necessary a relocation of the road, in order that it might not cross the canal line, and consequently the new road, constructed since 1907, runs on the east side of the canal from Colon to Panama. Between Mindi and Gorgona, and Pedro Miguel and Panama the old line has been abandoned, but it is still kept in service from Gorgona to Pedro Miguel to accommodate the villages on the west side of Gulebra Cut. (See also section Colon to Panama).

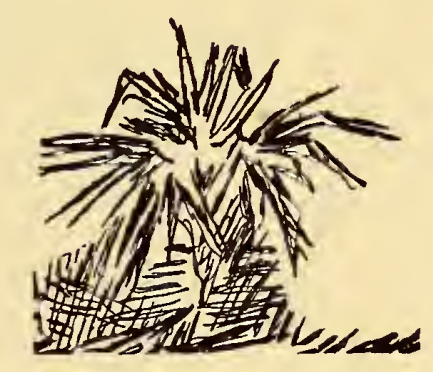




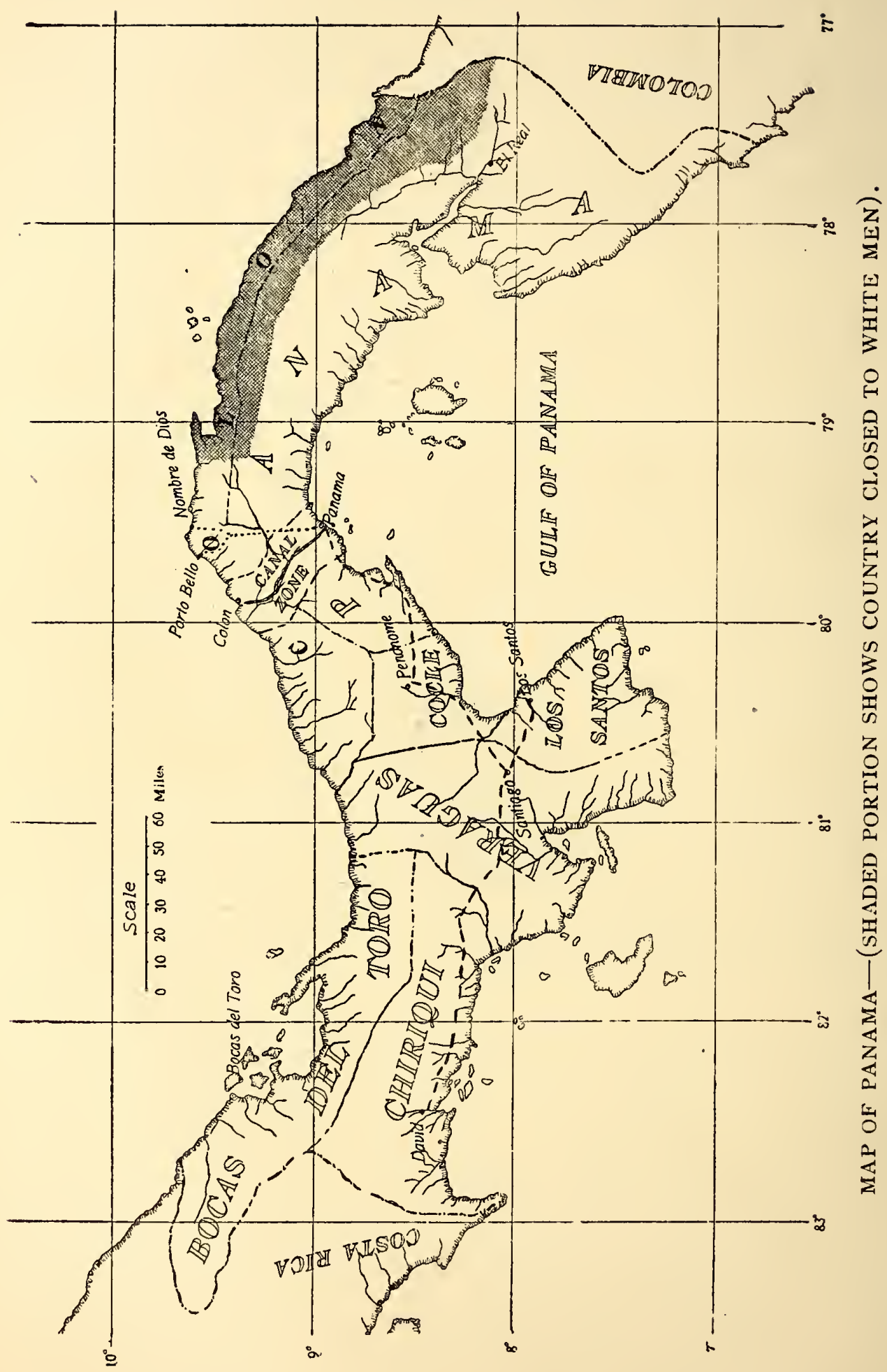




\section{History of Panama}

Leading Dates in History of Panama.

Discovery by Rodrigo de. Bastidas...............

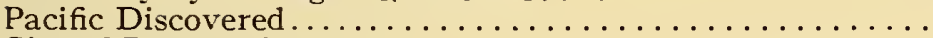

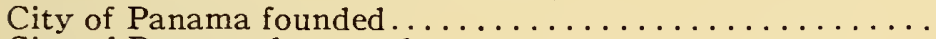

City of Panama destroyed.$\ldots \ldots \ldots \ldots \ldots \ldots \ldots \ldots \ldots$

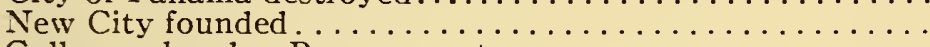

Galleons abandon Panama route................

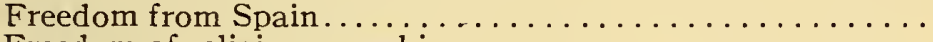

Freedom of religious worship $\ldots \ldots \ldots \ldots \ldots \ldots \ldots \ldots \ldots$

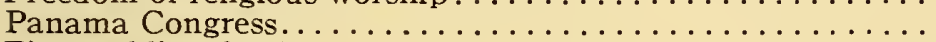

First public school. .....................

Slavery abolished $\ldots \ldots \ldots \ldots \ldots \ldots \ldots \ldots \ldots \ldots \ldots$

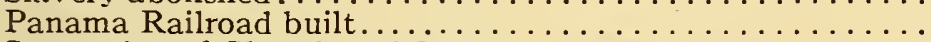

Separation of Church and State................

Ground broken for Panama Canal................

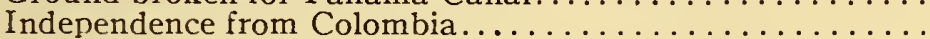

1501 September 25,1513

August 15, 1519

January 28,1671

January 21,1673

September 26

1821

1821

June 22-July 15,1826

July 16,1836

1848

$1850-55$

1863

January 10,1880

November 3, 1903

There are four great events in the history of Panama(1) The discovery of the Pacific Ocean, 1513. (2) The destruction of Old Panama, 1671. (3) The separation from Spain, 1821. (4) The construction of the Panama Canal, 1881-1914. The first two, and last of these events are geographical, the third is unimportant, except as it forms one of several local events from which schoolboys reckon history. Intrinsically there is just one big fact-Panama has never been an important influence in its own destiny. It has always been ruled from without, and usually misruled, first by Spain, then by Colombia.

In the brief sketch of its history that follows (and the reader should remember that this book is only a guide), Panama is considered in three epochs-the first that of the conquest and exploration (1499-1550), the second that of the great trade (1550-1750), the third the period of decline (17501903). The authorities consulted are referred to in the text. There is, however, only one real compiled authority for the local history of Panama, and that the Compendio de Historia de Panama, by Juan B. Sosa and Enrique J. Arce, published in Panama in 1911. This work was compiled at the instance of the Government of Panama as a text book for use in the schools. Wherever other authorities are in conflict with this, the book by Sosa and Arce is followed. The most interesting and accurate account yet published 
in English on the colonial history of Panama is that by Albert Edwards (MacMillan Co., New York, 1911), in his general work on Panama and the Canal.

\section{Conquest and Settlement.}

The old city of Panama (Panama Viejo) was founded in 1519 by Pedro Arias Davila (Pedrarias), and it was the first permanent settlement in the new world. It is said that Alonza de Ojeda was the first European to touch upon the shores of the isthmus, the date given being 1499 , and it is known that Columbus anchored in Limon Bay on his fourth voyage in 1502, and named the place Puerto Naos, from which was derived the name by which it was commonly known up to within the past generation, namely, Navy Bay.

The first attempt at colonization was made by Columbus at Santa Maria de Balen in 1503, but failed; and the second, at a point on the Caribbean coast, known as Nombre de Dios, about 20 miles east of Colon, where Nicuesa, having weathered a severe storm on his way from Porto Bello, sailed into calm water, saying "let us rest here in the name of God." This attempt also failed, and it was not until 1510 that a Spanish lawyer named Enciso, who had been one of Ojeda's expedition for the settling of the region south of the Atrato River, made a permanent station at Santa Maria del Antigua, so named in payment of a vow made to his protectress.

This colony, also, was later deserted, and it is chiefly important because it was here that Vasco Nunez de Balboa,

first came into importance as a bold leader

Balboa. and consummate politician. He usurped the governorship, and had a precarious rule over a turbulent band of three hundred adventurers for a period of two years, meanwhile subduing the Indians in the neighborhood. The news of his usurpation reaching Spain, he was summoned to return for trial, but, having heard of this in advance, he made his dash across the isthmus, hoping to return with the glory of new discoveries to help him in his cause.

From a mountain top overlooking the Bay of San Miguel in Darien, he first saw the Pacific Ocean on September 25, 1513. He made peace with the Indians, col-

Pacific Ocean lected some gold and pearls, and returned to 1513. Santa Maria, where he was arrested by the new governor, Pedrarias. Balboa was a 
schemer, and a leader, and with the glory of the new discovery and the admiration of the common soldiers all his own, he was a much larger figure than the new Governor.

Three years of bickering ensued, during which Balboa bore himself well under the jealous eye of Pedrarias, now made more hostile because the King had honored the discoverer of the Pacific with the title "Adelantado del Mar del Sur y Gobernador de las Provincias de Coiba y Panama," and had directed Pedrarias to consult him in all matters of public policy. Balboa made a second journey to the Pacific, actually transported small ships in pieces across the mountains, and floated them upon the South Sea.

A truce between him and Pedrarias was patched up, on the understanding that Balboa was to marry a daughter of the Governor and be a dutiful son-in-law. An enemy of the Adelantado pursuaded Pedrarias that Balboa loved too much his Indian mistress to carry out his part of the agreement, and that he really intended to set up a separate colony on the Pacific. Pedrarias recalled him to Acla, and, after the pretense of trial, had him beheaded in January, 1519 , when he was 44 years old.

Immediately after the discovery of the Pacific the work of exploration was begun. Espinoza and Pizarro visited the Gulf of San Miguel and the Pearl Islands (1515), and everywhere met the indians with a cruelty that begot cruelty, where Balboa had made friends. In the same year Badajoz pushed into the interior of the isthmus farther west, and coasted along the south shore from San Miguel Gulf to Chame. Espinoza (1516) made an incursion into the present provinces of Los Santos and Veraguas.

Soon after the execution of Balboa, Pedrarias crossed the isthmus and explored the coast from the Gulf of San Miguel to the island of Tatoga. By accident

Founding of he met with Espinoza at a native fishing vilPanama. lage called Panama, ${ }^{*}$ and there on August 15,1519 , he formally declared the site that of of his future capital.

\footnotetext{
*The name Panama is derived from one of the primitive languages of the aborigines. Concerning its significance various opinions are held. Some believe it was the name of a cacique who lived in chis locality at the time of the arrival of the conquistadores; some that it signifies the "land or place of the mariposas;" still others that it is cognate with the name of a tree abundant on the isthmus and especially so on the site on which was built the old city of Panama. Over all these opinions there has prevalled the one that the name "Panama" belonged to a small village of Indian fishermen on the site later known by the foundation of that city, and that it signified in the Cueva language, the one most extensively used by the
} 
The exploration of the coast by a party in boats and one on land continued, the sea expedition going as far as Nicaragua, while that on land explored Chiriqui,

Nombre de and collected a quantity of gold from the Dios and homes of the living and the graves of the Panama. dead. In 1520, Nata was established as an outpost. Meanwhile Pedrarias established a new village on the Atlantic side, as nearly opposite Panama as he could, at the old harbor of Nombre de Dios. On September 15, 1521, Panama was made a city by royal decree, and became the seat of a bishop. The inhabitants of Acla were forced to move to the new site, and that village was abandoned and its buildings destroyed.

From Panama in the following thirty years went out expeditions that explored the isthmus from the shore to the mountain tops. Thence Pizarro and Almagro set forth on the voyages that ended in the discovery of Peru (1524). From here in 1527 went out the expedition under Serna and Corzo that, before its return, explored the Rio Grande to its source, crossed the divide at Gulebra, and sailed down the Chagres to its mouth (April 3-10, 1527), thus traversing the route which the canal now follows.

"As early as 1535 vessels had begun to go westward along the coast from Nombre de Dios to the mouth of the Chagres

River, and through that river to the head of River Route navigation at a point, Venta Cruz (Gruces), and Trails. 34 miles inland, where cargo was transferred by trail to Panama, only 18 miles distant.

"Thus during the first half of the 16th century, two distinct routes were established across the Isthmus, one from Nombre de Dios overland to Panama, and the other a part water and part overland route from the mouth of the Chagres to Panama. Over these highways was carried "the wealth of Peru." Judged in the light of that time, this wealth was great, and moreover it was sudden. Into a world accustomed to steal from itself, to live on the pillage of nearby peoples, there was thrown, within the life of a generation, a quantity of gold greater than all known of theretofore; into its hands were placed opportunities for exploiting an alien people, such as had never been imagined. And for

thorigines of Panama at this time, "ablindance of fishes, or place abounding in fish." This derivation conforms with that which Pedro Arias de Avila gives in a letter written in the year 1516 to King Ferdinand and his daughter, Princess Juana: "Your Highnesses should know that Panama is a fishing place on the coast of the South Sea, for the Indians call fishermen Panamá."-Sosa and Arce. 
nearly two centuries Panama was the market place of this trade, and the trails of the Isthmus never ceased to hear the tinkle of the pack-train bells.

"These trails are stillindicated on the maps as the "Camina Real," or "king's highway" as they would be called in English. At first they were only trochas through the jungle, but before 1550 they had been paved with field rock, gathered along the route. Canal surveyors working in the jungle today occasionally run across these paved roads and find then uniformly about 4 feet in width, with no evidence of drainage, and following the natural lay of the land. Yet one must not forget the roads of England at that time; it was a period in which the art of road-building had fallen into neglect. In Panama the jungle may be driven back, but it can not be conquered; only by continuous occupation can cleared ground be held. The trails of the 16 th and 17th centuries have long since reverted to jungle, and great trees have grown up through the pavements." *

In this period, from the year 1534 to 1536 , studies were made, under the direction of the Governor of Panama in compliance with a royal decree of February

Panama 20, 1534, of a route for a canal across the isth-

Canal. mus by the Rio Grande and Chagres rivers. The cost was declared prohibitive. Nearly a century later (1616 to 1619) when the plan was again discussed, this time for a canal by the Atrato and Tuyra Rivers, it was deemed bad policy because the way would be equally open to the vessels of Spain and those of its already active enemies. There is a story that the clergy of the court of Philip III discouraged the project as a direct insult to God, who had placed the isthmus where it is. The writer has been unable to trace this story to its origin, but it sounds as though it were manufactured in New England.

The Government of Castilla del Oro (golden Castile), or of Terra Firma, as the Isthmus of Panama was called, was vested during this period in a Governor, Government. or an official who acted in that capacity. Under him were the governors of the various outposts, and the city and village officials. The ccurts were in the Audience of Panama, which had four judges, cne of whom was President. This president acted as governor of Castilla del Oro much of the time.

*Porter's Progress of The Nations. 
In the earliest days of the isthmus the governors were the captains of expeditions sent out fronı Spain or the West Indies. Their rule was over a set of unruly adven turers, largely soldiers of fortune, and they exercised it as a military commander would. From the time of Pedrarias the Governor was supposed to act according to fixed laws, but the local conditions made him in reality a military chieftain, who had either to rule as a dictator or not rule at all. There was justification for the hard rule of Pedrarias in this, although nothing would justify his lack of wisdom in ruling with cruelty.

From the very beginning the local government was beset with internal quarrels, such as that between Pedrarias and Balboa, and with external trouble, such as the revolution in Peru, and the attacks of the Indians and the cimarrones, as the escaped negro slaves were called. Among these was the rebellion against Pedrarias carried on in Nicaragua by Fernandez in 1526, and put down with a stern hand by the Governor. The civil war in Peru was felt in Panama by the taking of that city and further maltreatment of its inhabitants on two distinct occasions, 1545 and 1546. An uprising of Spaniards from Nicaragua under the Contreras brothers in 1550 resulted in the capture of the city and the maltreatment of the inhabitants. It will be seen from this that nothing but a military government would have been possible in a country that, inside of fifty years, had on its hands three well developed revolutions against the royal authority, in addition to the usual troubles with the aborigines.

One of the original ideas of colonization was to divide the conquered country into large estates and assign to each lord of the manor a certain number of slaves. Indian Slaves This idea was not new, but only an application

Liberated. of the plan of conquest carried out in Europe. It is probable that the Indians of Panama were in no worse fortune under their Spanish masters than the Saxons in England were during the early years of the Norman occupation. Inevitably the practice led to grave abuses, and at an early date, thanks to the efforts of missionaries, laws were passed forbidding the abuse of slaves. These laws were not obeyed, however, and at the instance of Las Casas (the strongest and noblest figure in American colonial history) the King in 1549 decreed the freedom of the Indian slaves. Those of Panama were set at liberty and given lands for their own cultivation. The slaves from Venezuela were 
given the island of Otoque, the Nicaraguans the mainland near Chame, and the remainder the island of Taboga. In each settlement a church was erected and tools were distributed for farming.

One of the means taken to alleviate the condition of the Indian slaves was the importation of negroes from Guinea. Sosa and Arce say that negroes had been Negro Slaves. brought to the isthmus in the earliest days as body servants, and that before the founding of Panama there were a number of them working in the fields and mines. From time to time these slaves would escape into the interior of the country, and by the middle of the 16th century they had formed little bands that waylaid pack-trains, and made incursions into the isolated settlements. They mixed with the Indians, and increased rapidly in numbers. Throughout the subsequent history of the new country they are known as "Cimarrones." By their help pirates and contrabandists harassed the isthmus. They were a large factor in the abandonment of Panama as the great trade route.

In spite of all its trouble the city was growing, because there was wealth in Peru and in Panama, and adventurers or pioneers braved the dangers of the new Growth of country, its diseases, and the turbulent semiPanama. camp life for the sake of money. Before 1550 the cathedral in the old city had been built, a wooden structure, and the foundations had been laid of the Church of Our Mother of Mercy. The city had about 3,000 free inhabitants, and there were 2,000 more in Nombre de Dios and the surrounding outposts.

\section{Period of the Great Trade (1550-1750.)}

In this period came the rise and decline of Panama's trade. There were three main causes for the decline-Spain's own decadence, the attacks of English and French on the commerce of the Indies, and Panama's inability to turn to internal development, as the trans-isthmian trade decreased.

It was only by chance that Spain became the first great colonizing nation. She was not prepared for the work, and did not learn. The wealth of Peru and

External Mexico was used in waging wars for the supAffairs. pression of political and religious independence, wars against France and England, in which she had nothing to gain and in reality did lose 
her European possessions, a Quixotic war against the Turks, and finally the foolish wars of succession to determine which of two worthless royal houses would reign in Spain. The Spanish renaissance of $1750-90$, short lived and futile, came too late to have any effect on the colonies. They had learned that Spain regarded them purely as a source of revenue, and had also learned the beginnings of the lesson of selfdependence. Yet all these wars in Europe affected Panama, for the continual state of hostility gave rise to the ceaseless attacks on Spain's commerce, and even in the few years of peace that intervened at home, there was no peace in the colonies.

In this period the royal authority was threatened by a revolution in $\mathbf{1 5 6 3}$, in which a leader named Mendez and his band took advantage of the absence of the

Internal Governor at Nombre de Dios to attack and

Affairs. occupy the city of Panama. Mendez was captured and executed.

The cimarrones began a series of attacks on the Government in 1549, when one of their chief tains established himself on the Gulf of San Miguel, and devastated the country, until defeated by a regular expedition from the city. In 1553 to 1554 a negro named Bayano became so bold in his raids on the pack trains that a regular expedition was sent against him, which he defeated. A second expedition surprised and took him prisoner, but a well-meaning Governor allowed him to go on his promise to be good. He broke his parole and after a hard campaign was captured and sent to Spain. But his companions continued their depredations on the pack-train commerce. The name of this chief is retained in the region where he ruled, for the Chepo River is commonly called the Bayano.

In 1637 the Indians of Darien under an able chief tain rose against the Spaniards and laid waste the towns of that region. A treaty of peace was finally made in which they recognized the King as their suzerain, and in return were let alone by the Spaniards.

In the period 1556 to 1600 the work of colonizing Veraguas was carried on with the loss of many lives, innumerable little quarrels with the Indians, and no great benefits to anyone.

Within the city itself there was a fire in 1563 that destroyed forty buildings; and another in 1644 that burned 83 buildings, among them the new cathedral in process of con- 
struction. The city itself was destroyed in January, 1671, when the pirate Morgan captured it. Of this and the founding of the new city more is told elsewhere in this book (pages 117, 151, 179.)

The government of the colonies was vested in a home administration consisting of the Council of the Indies, residing in Spain, and colonial officials with various titles corresponding to the amount of authority vested in them -viceroy, captain general, governor, adelantado, cabildo. Judicial authority in the colonies was vested in Royal Audiences; from whose decisions there was an appeal to the Council of the Indies.

The Council of the Indies had jurisdiction over all matters pertaining to the colonies, was, in short, the King's adviser on colonial affairs. Under it came even the

Government. viceroys, and all the colonial officials held office at its pleasure. In the course of the first century it compiled the body of laws known as The Statutes of the Indies, from which much of the information about colonial government and its development is obtained. These laws were carefully compiled to meet every emergency that might arise, and were admirable in many respects, but they were not fitted for the conditions. In consequence the colonial governors were dictators, the courts were maintained to aid the dictators, and, except for the removal now and then of an official for notorious malfeasance, there was no restraint upon the colonial governments so long as they turned in to the home treasury an annual tribute deemed worthy of the colonies.

In 1538, the Royal Audience of Panama was established with a President who had the authority of a viceroy, with jurisdiction over all of South America to the boundary of Mexico. In 1543, Panama and Nombre de Dios were made subordinate to the Audience of Guatemala. In 1563, the Royal Audience was again transferred to Panama, where it remained until 1718, when, in an effort to put an end to continual civil war in the colony, Panama was made subordinate to the viceroyalty of Peru. In 1722, the Royal Audience was restored to Panama where it remained until 1739, when Panama became a province in the viceroyalty of San ta Fe deBogota.

There were three sources of the wealth that formed the home-bound trade of Panama-gold from the slave-wcrked mines of Darien and Veraguas on the Isthmus, gold and 
skins from Peru, and silver from Bolivia, known then as Potosi. In return for these Spain sent to her colonists on the west coast of South America clothing Sources of the and foodstuffs. All the efforts of the home

Trade. government were to procure as much precious metal and gems as possible from the colonies, and send to them as much as possible of the products of Spain. To this end agriculture in the colonies was discouraged where it could compete with the agriculture of Spain (for instance a flourishing wine industry in Peru was broken up), and all influence was brought to bear to make the colonists work the mines.

The people who came to New Spain were not of the working class, but rather broken-down gentry or middle-class merchants who wished to recuperate their fortunes. They would not work in the mines themselves; so there grew up two distinct classes-masters and slaves. There were, therefore, two great influences interfering with the real development of the colonies,- - the hostility of the home government to any but extractive industry, and the unwillingness of the colonists themselves to work.

The monopoly of trade with the colonies was vested in the Casa de Contratacion of Seville, formed in 1503, with the right to regulate trade, hear cases in admiralty,

Casa de and on contracts growing out of the trade. Contratacion. It prescribed at what ports ships should land their cargo, both in the colonies and in Spain, what class of goods could be carried, with what colonies various ships could trade, and in what fleets they might sail to and from the colonies.

The trade with the Indies and the Spanish Main was restricted to Spanish ships, and to such of these only as had charters from the Casa de Contratacion.

Trade Re- Ships not so chartered were regarded as pistrictions. ratical, and the masters and crews were enslaved or executed upon capture. The effect was to make illegal all trade by vessels of other nations; and the result was that for two centuries the French and English "free traders" harassed the islands and the Spanish Main, capturing treasure galleons, destroying cities, and finally driving the commerce away from the isthmus to the longer but safer route around South America. 
PRIVATEERS, BUCCANEERS, PIRATES.

As early as 1525 an English ship beaten out of its course by storm visited the West Indies. Upon its return to England the stories of the wealth to be gained by trade with the Spanish colonies excited the cupidity of seafaring men, and within twenty-five years English and French ships were carrying on a clandestine trade with the islands.

Spain looked upon these "free traders" as pirates, and whenever they were caught they were executed outright or held in servitude. Many of them worked out their lives building the walls of old Panama.

Instead of deterring the "free traders," Spain's drastic policy drove them to self-defense. They were not gentle, kind men, at best; but rough sailors, adventurers, cutthroats, unwashed people generally. Their attitude toward a fight was to go through it, never to avoid it or back out. Men-of-war in those days were merchant vessels with cannon aboard, and a skipper who could mount a few guns was just as well prepared to fight as a ship of the line with an equal number of guns. The English and French ships were smaller, and better-handled than the Spanish.

So it turned out that Spain had her hands full protecting her commerce; and she had no greater enemy in her efforts than her own subjects in the new world, who preferred the illegal trade, with its freedom from taxes, to that upon which the king levied his customs dues. In short, the trade with French and English was as advantageous to the Spanish colonists as it was to the "free traders," and evidence is not wanting that the so-called "pirates" were unofficially welcomed by many a colonial governor.

Officially, however, Spain hunted these "free traders," and forbade them the use of Spanish colonial ports and markets. On this account the ships' crews would go ashore on the mainland or an island to hunt wild cattle and procure other food. In one generation this business of supplying ships of the "free traders" became specialized, and French and English outcasts on various islands became meat-curers, or boucaniers. They gave their name to the semi-piratical "free traders," who later were known as buccaneers.

The dividing line between the privateers, like Drake, and the buccaneers, like Morgan, was purely legal. Essentially they were both pirates, stealing the property of 
others. The Spaniards in turn stole from the Indians and their negro slaves; so it was "dog eat dog;" and the real producers, as usual, got nothing but an existence from their labor.

So what Spain by her foolish policy left undone to kill her colonies, the English and French privateers and pirates did. The two hundred years following the founding of Old Panama were characterized on the Spanish Main by an international effort to get rich without working. The system is still popular in Spanish America and the United States.

French and English privateers and pirates were active in the West Indies as early as $\mathbf{1 5 5 0}$, but it was not until Francis Drake attempted to take Nombre de Dios in Drake, Oxen-1572 that the formal raids against fortified ham, and places began. On the night of July 9, 1572, Others. Drake surprised Nombre de Dios and had it at his mercy, but he was wounded and his men, taking fright, carried him to the ship and sailed away without the dear-bought booty. He hung around the coast, however, the scores of islands giving plenty of hiding places; made an unsuccessful foray into the interior, including a fruitless attack on Cruces (January 31, 1573); and, finally (May, 1573), surprised a treasure train from Panama near Nombre de Dios, and got away with considerable booty. In this work Drake was aided by Indians and runaway slaves.

By the aid of cimarrones, John Oxenham crossed through Darien in 1577, and from the Gulf of San Miguel sailed out upon the Pacific, the first Englishman to sail on that sea. He captured some small trading ships and from these captured a treasure galleon. Later he was captured by the Spaniards and his company enslaved or killed. In that same year an English freebooter named Sylvester captured Concepcion, in Veraguas, and robbed the mines.

In 1578, Drake plundered ships in the West Indies, rounded South America, plundered along the Peruvian coast, and sailed around the world without having attacked Panama. In 1585, he invested Nombre de Dios and Fort San Lorenzo at the Chagres mouth, but did not attack either. In 1595, however, with a fleet of 27 ships and 2,500 men he set out to take Panama. He attacked and destroyed Nombre de Dics (January 6, 1596), silenced the guns of San Lorenzo, and sent a force of $\mathbf{7 0 0}$ men in advance toward Panama by way of the Nombre de Dios trail. This force met such stout 
resistance that it turned back. Drake returned up the coast from the mouth of the Chagres, and at the entrance to Porto Bello (February 7,1597 ) died. The planned attack on Panama was abandoned.

On February 7, 1602, William Parker, English, made a raid on Porto Bello and got away with 10,000 ducats of gold and considerable personal property.

Unsuccessful attempts against Panama were made by the pirate Francis L'Olonnais (French) in 1650, but he was killed while crossing Darien, and by Mans-

Pirates- velt (English), who planned first to reduce Morgan and Nata. Toward the close of June, 1668, Henry

Others. Morgan and a band of English and French pirates, took Porto Bello and carried away considerable treasure. On January 6, 1671 he took Fort San Lorenzo at the mouth of the Chagres, and moved thence up the river to Cruces, whence he went overland to Panama and took that city. His raid is referred to under the respective headings, Porto Bello (page 190), Fort San Lorenzo (page 197), and Old Panama (page 179). In 1675, La Sonda (French) attacked Chepo, but was repulsed. In 1678, Burnano (French) captured and sacked Chepo. In 1679, La Sonda and Coxon (English) raided Porto Bello. In the following year Coxon crossed the Darien and from canoes captured some ships off the Pearl Islands. He cruised about the bay, making reprisals on vessels and isolated settlements; and captured Remedios on March 25, but was too weak to attempt Panama. In 1685 Henry Harris duplicated Coxon's journey, and for several weeks worried commerce in Panama Bay. He destroyed Chepo. In the Pearl Islands, on May 28, 1685, he was defeated by Spanish war ships and driven away. In January, 1686, a band of English and French pirates destroyed Alanje in Chiriqui. In June of the same year, Townley, an English captain, captured Los Santos, and procured a large amount of bocty. On November 24, 1686, San Lorenzo (Chiriqui) was captured and burned. In 1703, pirates surprised and captured Porto Bello, robbing the inhabitants. In the same year John Raasch with a band of English and cimarrones made an incursion into the Darien region and captured Santa Cruz de Cana in the midst of the mining region. Pirates all through this period hung about the Caribbean coast of the isthmus and waylaid vessels making for Pcrto Bello, both from the mouth of the Chagres and in the ocean trade. 
Not properly in the class of privateers or pirates was Edward Vernon, an Admiral in the English Navy, who made attacks upon the Spanish dominions in the Vernon's Cam- West Indies and along the Caribbean during paign-Fail- the war between England and Spain (1738ure to take 1743). Yet his work contributed to the same Panama. end as that of the illegal sea captains; namely, the driving of commerce from Panama. On November 22, 1739, he appeared off Porto Bello with a strong fleet. During the interval of peace with England the Spanish Governor of Terra Firma had allowed the defenses of the place to become weak, so that Vernon captured the town without much resistance. On March 24, 1740, he took Fort San Lorenzo, and on April 25, 1742, again attacked and took Porto Bello, which he held until June 11. The plan was to join with Admiral Anson, who had sailed around South America, in an attack on Panama from both sides, the latter from the Bay of Panama, and Vernon by land from the rear. The plan miscarried. Vernon's troops sent out towards Panama met everywhere with such stout resistance that they were unable to gain headway. Anson did not arrive to begin the siege; so Vernon evacuated Porto Bello. In 1741, Vernon attacked Cartagena with a powerful fleet and landing force, and met with the most complete repulse ever given an English fleet on the Spanish Main.

It has been said that both the Spanish and their European enemies on the Spanish Main and in the West Indies were essentially pirates, since they were actuContraband ated by the same idea, that of becoming rich Trade without working. The broad difference that is supposed to have existed between Drake and Morgan, and Morgan and the contrabandists of the eighteenth century, is almost purely legal. Drake had letters of marque, Morgan had none; yet both were honored by knighthood. The contrabandists who drove a flourishing trade in Panama lacked the strength to take cities, but they were essentially in the same business as Drake and Morgan; namely, that of evading the trade restrictions placed upon commerce by the Spanish crown.

The contraband trade was popular in Panama, where the King's tax on commerce was heavily felt. Indeed there are many evidences that officials as well as the people connived at it. Jamaica was the West Indian depot, and from there ships put out for the north coast of the isthmus, land- 
ing their cargo at the mouth of the Cocle, Veraguas, or other rivers, whence it was packed across on mules to Nata, and thence to the Pacific, a total distance of about 45 miles. A determined effort was made in 1743-1749 to put down this trade. In retaliation, William Kinghills sailed into Porto Bello harbor on August 2, 1744, with a fleet of 40 armed merchantmen under guise of friendliness, for the people were just as sorry as he was that the contraband trade was suffering. Once inside, he turned his guns on the city and after doing great damage sailed away.

The war against the contrabandists ended with the taking of their stronghold, Nata, on November 16, 1746, and the hunting down of the chiefs, who were drawn and quartered and their heads exhibited in the plazas of the principal towns in the region. This broke up the illegal trade.

The war on commerce by way of Panama began about 1550, and was waged unceasingly for two hundred years. This was the principal reason why the route was Desertion of abandoned. But there had been a general dethe Panama crease in the trade for a century before the Trade Route. abandonment; it had passed its height before Morgan captured Panama. The main source of wealth, the gold of the Incas, was soon exhausted, and it was more difficult to mine gold than to steal it. The increase in the power of England made it impossible for the Spaniards to maintain their pretense of trade monopoly in the West Indies. In 1655, the Island of Jamaica became an English colony, right in the heart of the Spanish colonial domain. Real industry had never flourished on the isthmus; there was little agriculture, little manufacture; the people lived by trade. When that trade was ended, the country rapidly diminished in importance. Of the abandonment of the Panama route, and its consequences, Sosa and Arce say:

"Peace with England having been signed, and the route by Cape Horn having become frequented by the seaborn trade of Spain with her colonies, the commerce of the galleons by way of the isthmus ceased. This determined the ruin of Porto Bello; began the decadence of Panama, and of other towns in the territory that had lived the unstable lives of traders at the annual fairs, as carriers of merchandise, and as longshoremen. The last of the galleons that sailed from Callao towards the close of 1739 found upon its arrival at Panama that the fleet of Vernon was besieging Porto Bello. It went back with the treasure to Guayaquil, and carried on its business with the Spanish fleet at Cartagena by way of the long and dangerous route from Quito to Bogotá. Trading after this time was carried on by way 
of the Cape, considered more easy and less expensive by the merchants of Perú and the neighboring colonies.

* * * In the six years-1749-1755-was witnessed the visible decadence of the country when, in contrast with the commercial activity of former times, there came a period of business retrenchment, during which there ensued the exodus from the country of many persons who had lived by means of business derived from the carrying of European merchandise and colonial treasure and products between the ports of the isthmus. After the squadrons of galleons adopted the way around Cape Horn, there arrived at the port of Panama from Pacific-Coast ports scarcely ten or twelve ships a year, and at Porto Bello from Spain and the ports of the West Indies, about the same number in the same length of time. Under these conditions the annual royal taxes did not exceed one hundred thousand dollars, a sum insufficient to meet the urgent necessities of the public service. The prostration of business had reached such a state that in the whole country there did not remain a person who had fifty thousand dollars capital, after the great fortunes of the former epoch had left in search of new fields for investment."

\section{From Decadence to Renascence (1750-1903.)}

The milestones in this period are the independence from Spain (1821), the completion of the Panama Railroad, (1855), and the construction of the Panama Canal (1881 to 1914). The first seventy years were quiet ones, in which good officials administered the affairs of the provinces of the Isthmus with forbearance and wisdom, and yet years in which Panama, Porto Bello, and the places nearby were prostrate, because of the abandonment of the trade route. The following ninety years were vexed with internal strife, and Panama garnered in bitterness all of the fruits of its industrial incompetence, its lack of ethnic unity, and its dependence on others for government and protection.

The Audience of Panama was abolished by decree of June 20, 1751, and Terra Firma, as the Isthmus was still called, was made a Captaincy General under the super-

Government vision of the Viceroy of Bogota. The captains general governed without internal opposition from this time until 1821, the only political event of importance during that time being the transfer of the viceregency to Panama in 1812 for a year, while the revolutionists in Bogota made residence in that city impossible for the Spanish viceroy. The social movement, in Europe epitomized by the French Revolution, made headway on the Isthmus, although slowly, where "the rights of man" made a varied appeal to the people of four distinct classes. The revolution in Spain, mixed as it was with the claims of 
Charles IV and his worthless son Fernando VII to the throne, the interference of Napoleon, and the rise of Republicanism, affected the colonies vitally, because it made the mother country unable to check the revolutionary propaganda in Latin America. Yet Panama remained loyal to Spain, and was the last of the South American colonies to declare independence.

This loyalty was based largly upon incompetence. The lack of ethnic unity * on the Isthmus, of economic independence, distrust of Bogota with whom her revo-

Panama lutionary destinies must be placed, and the Fiel. presence of strong garrisons, all had an influence on that loyalty, which caused the home government, in 1814, to confer upon the Isthmian cities the title of "Faithful."

It was a dispute between two men of the two first classes, Spaniard and creole, in Bogota on July 20, 1810, that precipitated the first open revolutionary movement in Colombia, although the seed had been sown thirty years before.

The junta that took charge of the Bogota Independence government "in the name of the king" asked from Panama to join in a movement for home rule, Spain. but the authorities of Panama refused, declaring their allegiance to Spain, and raising two battalions for the purpose of repelling any attack that the revolutionists might make upon the Isthmus. One of these was sent to Quito and assisted the Government forces in the war against the revolutionists. In January, 1814, an unsuccessful attack was made by the Colombian revclutionists on Porto Bello, and in April, 1819, Gregory MacGregor took

\footnotetext{
*The passing of the eighteenth century marked at each step a further decadence of the Isthmus, whose ruin was almost total, and the apathy of whose sons was pitiful, incapable as they were of stemming the tide of econClass omic and social disaster. The chief element in this incapacity

Distinction. was the heterogeneous character of the population, and the distinctions and privileges that arose therefrom. Four distinct social groups existed in the colony: European Spaniards; the creoles, sons of the Spaniards but native born; the Indians; and the negroes, both free and slave. For the first were reserved the high political positions, and they also held the better classes of business and certain offices. Public positions of minor importance were held in the cities by the creoles. and la.ter they were able to enter the church, the army, and the law professions, which opened to them other public positions. The population of the interior was composed largely of the poorer creoles who followed agriculture and cattle-raising. The mechanical trades. considered degrading, were carried on by the lower classes, which were the product of the crossing of white, Indian, and negro blood. The mestizos, for instance, were the whites with the negross, and the zambos of the mulattos with the Indians. The Indians were engiged especially in farming and small stock-raising, and to the negroes was left the work of mechanics, mine laborers, porters, and domestic servants.-Sosa and Arce.
} 
the place for the revolutionists, but was afterwards defeated and made prisoner. In April, 1819, John Illingworth, an Englishman in the service of Chile, took the island of Taboga, and tried unsuccessfully to exchange, with the authorities at Panama, his prisoners for those taken by the Spaniards at Porto Bello. Bolivar started in the summer of 1821 to make a campaign on the Isthmus, but was deterred, and meanwhile the Isthmian independence was declared.

During the time of Panama's favoritism in Spain, 1814 to 1816, the Government at Madrid made plans to open trade by the isthmian route, and to restore to Panama some of its old wealth, by making it a free port. But the Government of Spain was not sure of itself for a day at a time, and the plans were not put into execution.

On all sides the revolutionary movement was in progress, and towards the end of 1820 its success became assured. Naturally the foment was working in Panama. In August, 1821, there arrived on the Isthmus Field Marshal Juan de la Cruz Murgeon, with the commission of viceroy, charged with the task of crushing the revolution in Colombia and Ecuador. He reinforced his command with the greater part of the garrisons of Porto Bello, San Lorenzo, and Panama, and set sail for Guayaquil, leaving in charge of the Isthmian government, Col. Jose de Fabrega, Governor of the province of Veraguas. The revolutionary committee, by means of bribes, persuaded most of the soldiers remaining in the garrison to desert, so that there was no force on the Isthmus to help the Governor to maintain theroyal authority even if he wanted to do so.

The first open movement was in the village of Los Santos where on November 13,1821 , a declaration of independence was made. Other interior villages followed this lead.

On the night of November 27, sixty soldiers November 28, deserted from the garrison in the city of Pana1821. ma, and on the following day at a meeting of the officials, church dignitaries, and the revolutionary committee, held in the city hall on the central plaza, independence was declared. Fabrega was continued in charge of the provisional government, and the soldiers that remained in the garrisons on the isthmus were given passage to Habana. By executive decree of February 9, 1822, Panama became the Department of the Isthmus in the new republic of Colombia. 
The period from the declaration of independence from Spain to that of the declaration of independence frcm Colombia (1821-1903) was fretted with internal

Political strife; for Panama reflected all the civil wars Infancy. of Colombia, and had a few of her own. This may well be called the period of political infancy for the isthmus showed in all its political life the need of a protector. The first taste of republican government was a bitter one for Panama. Frcm the time of his arrival in 1822, the military governor of the new Department, Jose Maria Carreno, treated the people as though they were soldiers, enforcing camp discipline among them. They soon became dissatisfied, and in 1826 the civil government was vested in Juan Jose Argote, leaving Carreno in command only of the garrisons. But the isthmian people knew from that time forth that their new liberty did not of necessity mean greater peace and comfort than they had known under Spanish rule.

Bolivar was a dreamer, and one of his fancies was of a strong defensive union of all Latin-American republics. After the decisive victory at Ayacucho (De-

Congress of cember 19, 1824) he called the Latin-American Panama. Congress, which met in Panama (June 22July 15, 1826), with delegates present from Colombia, Mexico, Peru, and Guatemala. Many plans were discussed and some agreements made, but there were no direct results, because the nations represented were not capable of keeping internal order, much less of keeping agreements with one another.

The civil war in Colombia in 1828, and the war with Peru in 1829 , both affected the quiet of the isthmus, where large garrisons were stationed, and in the latter war an attack on shipping in the harbor was made by Peruvian frigates. On September 26, 1830, only eight years after independence from Spain, the isthmian people

First Revo- declared their independence from New Granaluion. da (as Colombia was called after the defection of Ecuador and Venezuela from Grand Colombia in 1830), and for two months maintained an independent state in Panama under the dictatorship of Jose Domingo Espinar. On December 11, of the same year the isthmus was reincorporated in the federation of New Grenada, a loose union formed after the reaction against the centralization policy of Bolivar and his followers had proved a 
failure. This movement is interesting chiefly because it was the first revolution, and because it was the avowed intention of the new Panama government to seek the protection of some European nation.

On July 9, 1831, the Governor, Juan Eligio Alzuru, assisted by minor officials, declared Panama independent of New Granada, and made himself dictator. Second Revo- A force sent out from Cartagena, to assist lution. the Panama Governor in maintaining order, found upon reaching the mouth of the Chagres that he had started a revolution. This force was strengthened by recruits from Colombia and Veraguas, and under the leadership of Tomas Herrera, assisted by Colonel Fabrega, defeated the Dictator near Chorrera and entered Panama, August 25, 1831. Alzuru was shot in the Plaza Central on August 29. The authority of New Granada was reestablished by Herrera in a wise and peaceful manner; but in the middle of his labors, March, 1832, he had to put down a conspiracy for uniting the isthmus to Ecuador. In the confederacy of New Granada, Panama and Veraguas were made separate provinces each with its own Governor.

The effort made in New Granada in 1837-1841 to expel the Minimite monks and expropriate their property, resulted in a civil war in which the administraThird Revo- tion was successful. Taking advantage of the lution. war to show disapproval of the neglect which Panama had experienced at the hands of the government in Bogota, Panama declared its independence on November 18, 1840. A convention in June, 1841, ratified the act of separation and named as governor and vice-governor the leaders of the revolution, Tomas Herrera and Carlos de Icaza. The revolution in New Granada having been put down, an army was despatched to Panama, but peace commissioners preceded it, and a treaty was made on December 31,1841 , by the terms of which the isthmus was reincorporated in the New Granada confederation.

The California pioneers numbered some men of the rowdy class, just as the present American population on the Canal work does. In the days of waiting The Water- in Panama for ships to California, these rowmelon Mas- dies made considerable trouble for the police. sacre. On April 15, 1856, one of them tried to cheat a fruit-stand man out of the price of a peice of watermelon. A row ensued which resulted in a riot. 
and a mob pursued the American and his friends to the railroad station. There was a pitched battle in which the station was wrecked; 16 Americans were killed and 15 wounded. An international conflict was averted by the payment by Colombia of $\$ 400,000$ indemnity.

From 1842 until the final separation from Colombia in 1903 , there were 22 political uprisings in Panama that could

be counted as revolutions, since their object, Sixty Years of and in some cases the result, was the overRevolution. turn of the existing government. This was an average of one revolution every three years.

It is so much the habit of American newspapers to make fun of the Latin-American revolutions that space is taken here to point out the chief influences that make them possible. The first influence in the revolution, as a characteristic method of expressing discontent, is climate. It could not be used in any country where it is necessary to buy focd and clothing for the army. In the tropics a popular leader can talk to a few friends and they to a few hundred people of the laborer or farmer class, and by promising relief from real oppression, can start a movement to wrest the control of government. The man who works in Panama is usually one without schooling, one who lives from hand to mouth, and his condition can not be worse. In a dull way he knows it should be better. He is always ready for a change. $\mathrm{He}$ is very like an Anerican in that he attributes his economic troubles to the government entirely. He has a real cause for dissatisfaction; he does the work and gets a bare living, while his superiors get a fat living and merely order him in the work. Another basic cause is the lack of ethnic unity, the strong class feeling along racial lines. The "morenos" or brown people outnumber the whites 20 to 1 in Panama, yet they have but small influence in the government. There is reason, too, for the belief that the local administration on the isthmus under Colombian rule was usually unwise, of ten bad, invariably weak. All the conditions, therefcre, were right for revolutions of a riotous nature in place of the election held in the United States every four years. The independent American voter, who blanies the government for a financial panic, shows less political sense than the Panaman who blames his government for patent abuses.

Many of the revolutions were confined to one battle and only three of them lasted for more than a few months. They were bitterly fought (the Panaman is brave, and a 
hard fighter), and they helped to widen the breaches between various families and classes, so that each war was the seed for another. The revolutions in which blood was shed occurred in $1862, ' 64$, ' 65, ' 66, ' 68, '71, '73, '75, '76, '79, '84, '85, '86, '95, '99, and 1903. Only four of these were national in the sense of being Colombian, the balance being entirely local to Panama, and settled one way or the other without interference from Bogota. On the other hand sonie of the revolutions in Colombia did not cause any outbreak in Panama.

In 1855 by act of the New Granada legislature, Panama was made a State with absolute control of its domestic affairs. This was a wise move because it les-

Home Rule sened discontent on the isthmus, and freed the for Panama. Bogota government from any obligation to assist in keeping order in Panama. This status was not changed in 1861 when the central government readopted the name, United States of Colombia.

The Liberals came into power at Bogota in 1861, and contrary to the constitutional guarantees of the isthmus, placed garrisons there to maintain the Liberal Government. Panama had taken little part in the civil war that ended with the triutuph of the Liberals, and this was resented by the new Government. Innumerable affronts to the Panaman's right of local self government were offered, and the ten years that followed were constantly disturbed by small outbreaks. In 1873, the Conservatives started a formidable revolt in Chiriqui and Veraguas, which, although subdued in a nionth, resulted in the loss of hundreds of lives, and the widening of the breach between the two parties.

The annual reports of the Isthmian Canal Commission contain complete records of earthquakes in Panama for the current years. The severest of authentic

Earthquake record that has occured up to this time was of 1882 that of September 7 to 11, 1882, when the seismic disturbances lasted over a period of four days. Three severe shocks were felt, in consequence of which part of the facade of the Cathedral fell into the street, the apse arch of the ruins of the Church of Santo Domingo collapsed, the old cabildo or town hall was badly broken, tracks of the Panama railroad were thrown out of alignment, houses were shaken down in Colon, a fault appeared in the earth in Colon, and there was a tidal wave in the Caribbean off Darien. 
A general revolution broke out in Colombia in 1885, due to the efforts of the President, Rafael Nunez, to introduce measures for conciliating all parties. He Revolution was a Liberal but the Radicals of his party obof 1885 . jected to his methods, and State after State rose in revolt. On the Isthmus the Liberals were in control, also; but General Aizpuru, former President of Panama, seized the opportunity to start a revolution. He was obliged to retire from the city after an attempt to stampede the garrison, and reinforcements were hurried to Panama from Colon. This left Colon without Government troops, and there Pedro Prestan raised the standard of revolt. He tried to seize a shipment of arms on an American vessel in the harbor, but was prevented from doing this by the $U$. S. S. Galena, whose commander took possession of the ship. Meanwhile a battalion of 160 men was hurried to Colon from Panama, and at Mount Hope met and defeated the poorly armed revolutionists on the following day, May 18, 1885. The troops after a little more fighting entered Colon, and order was being established there when fire broke out and destroyed all but seven buildings in the

Burning of town. Ten thousand people were made homeColon. less, and the loss was six million dollars. The fire was attributed to Prestan and his followers.

He fled to Cartagena, but the revolutionists would have nothing to do with him, and falling into the hands of the Government he was sent back to Colon, tried by court martial, and hanged, August 18.

While the troops were absent in Colon, Gen. Aizpuru entered Panama and after a brisk skirmish took the city. An armistice of a month was declared, and End of War- at the instance of the Colombian Minister Panama a in Washington, the United States Government, Department. acting under the treaty of 1848, landed a thousand marines to protect the Isthmian transit. Meanwhile a force of Colombian troops was sent to the Isthmus, and pending their arrival the American marines took charge of the city, arresting the revolutionary chiefs, who were soon set at liberty, however, on promise not to fight within the city. The Colombian force entered the city without resistance on April 29. As a result of this war the constitution of 1863 was amended, and a more centralized national state was erected, known as the Republic of Colom- 
bia, in which Panama and other former States were merely provinces, but with a large measure of local self-government.

A result of the effort of a coalition of Conservatives and Liberals in Colombia, calling themselves Nationalists, to form a strong central government, was that

The Three from 1885 to 1900 Colombia, and consequently Years'War. Panama, was ruled by military dictators. The rule was arbitrary, and the very strength it evidenced in putting down revolt from time to time, was one of the causes of the Liberal Revolution of 1899-1902, known as the three years' war. Belisario Porras, with a force recruited in Costa Rica, set up in Chiriqui on March 29, 1900 , at Burica, a provisional government, and with recruits from all parts of the Isthmus joined a force under Emiliano J. Herrera, the military chief of the new government, at Aguadulce in Veraguas. The revolutionary army gradually approached the capital, defeating the Government troops at Bejuco and Corozal. On July 24 and 25, the Liberals, 1000 strong, were victorious at Calidonia, a suburb of the city, and could have entered Panama. By advice of the Amcrican consul in Panama, H. A. Gudger however, and because a Colombian force of a thousand men had arrived at Colon, they agreed to withdraw, the Colombian Governor, Charles Alban, agreeing that they would not be prosecuted for their part in the insurrection.

The insurgents retired from the line of the railroad, but kept up a harassing guerrilla warfare in all parts of the country. In September, 1901, Domingo Diaz landed a force recruited in Nicaragua on the Isthmus, and there ensued a series of bloody skirmishes at Empire, San Pablo, and Buenavista (Bohio). The revolutionists were driven back from the railroad line, and were forced to yield Colon, which had been taken by surprise on Septemker 19. In all this warfare the revolutionists had the sympathy of the mass of the people, because they were fighting against a government that was at once alien and oppressive.

Meanwhile Gen. Herrera had been recruiting a force along the west coast of Colombia, and in Decemter he landed on the Isthmus with 1,300 men, and at Anton incorporated in his command the guerrilla band under Pcrras. Throughout the interior the revolution was successful, until the middle of 1902 , when a government force of 2,000 men made some gains in Cocle. Negotiations were opened for peace, and this was accomplished on November 21, 1902, on board 
the U.S. S. Wisconsin, when concessions were made to the revolutionists, and a general amnesty was declared.

The peace lasted until the fall of 1903 , when it became evident that the government at Bogota would not ratify the treaty allowing the United States to con-

Revolution struct a canal across the Isthmus. Then ensuof 1903 . ed the bloodless revclution of 1903, when by the aid of the United States, Panama became independent of Colombia, and a protectorate of the United States.

It is not the intention here to discuss the right of this revolutionary movement, nor to add a word to the debated question of who got the money paid by the United States for the French canal rights. The facts are as follows:

The Isthmian Canal Commission of 1899-1901 advised the Government to construct its isthmian canal across Panama along the line of the partially completed French canal, provided the French company's rights and property could be purchased for $\$ 40,000,000$. To the end of consummating the purchase, a law was passed by the United States Congress on June 28, 1902, providing for the purchase, in case an agreement could be made with Colombia for the perpetual lease of a canal zone with rights of sovereignty therein for $\$ 10,000,000$ and an annual rental of $\$ 250,000$. John Hay for the United States and Tomas Herran for Colombia prepared a treaty which, to become effective, must be ratified by the United States Senate and the Colombian Congress within eight months after January 20, 1903. Colombia's Congress passed the treaty in the lower house, but the Senate hesitated.

The alienation of national territory was declared unconstitutional by some Senators, and the price to be paid was declared insufficient by others. The Hay-Herran concession of the French company was about

Treaty. to expire, and it was openly argued that the matter should be held up until the canal rights reverted, when Colcmbia would get five times ten millions. The Panama representative in the Senate returned home with the information that the treaty could not be ratified at Bogota unless the United States was willing to pay more than ten millions. Finally, on August 12, 1903, it was definitely rejected.

The law authorizing the purchase of the French canal rights stated explicitly that if the purchase could not MR 22928—9 
be made, the canal should be constructed Panama's across Nicaragua. The alternative meant Dilemma. ruin to Panama. It would be worse than if no canal had been constructed at all to have one across Nicaragua, in competition with the Panama Railroad transit. It never did take much to start a revolution in Panama, and the Isthmian leaders, financed by French canal stockholders, went frankly to work to declare independence. By September, representatives of the revolutionary junta had gone to the United States and sounded the Government at Washington as to its attitude in case of a revolution. Whatever the answer was, the movement persisted. Meanwhile the Colombian government knew all about this, but took no measures to meet the crisis. President Sanclemente hoped up to the last to force the treaty through the Senate, although the eight months' limit had expired, and he depended moreover on the terms of the treaty of 1848 , which stipulated that the United States would maintain the sovereignty of Colombia on the Isthmus.

November 4 was fixed for the declaration of independence, but on November 3 a Colombian battalion of 500 men landed at Colon to prevent the separa tist moveIndependence ment. The commanding officers hurried to

Declared. Panama to take command of the garrison, but the chief of the garrison, Esteban Huertas, had been won over to the revolution, together with the officers. The Colombian officers were made prisoners; and at 4 o'clock the following afternoon, the formal declaration of independence was made in Cathedral Plaza. The only fatality was that of a Chinese citizen killed by a shell fired from the Colombian gunboat Bogotá, which had begun to shell the city, because of the refusal to release the Colombian generals, but which was driven away by some shots from rapid-fire guns mounted on the sea-wall.

In Colon, the Colombian troops were refused carriage across the Isthmus on the morning of November 4 . The news of the coup d'etat in Panama reached the

Landing of ears of the Colombian colonel, and he threat-

Marines in ened reprisals on the city of Colon. It was Colon. probably only an idle threat, but some marines, landed from the $U$. S. S. Nashille, placed the old masonry freight building in condition to protect the American residents, and this prompt action decided the 
day for peace. On the following day the Colombian troops were sent back to Cartagena.

On November 6, the United States recognized the independence of Panama. From November 4, 1903, until February 26, 1904, Panama was a sovereign state; and on the latter date, when the treaty with the United States was signed, it became a protectorate of the United States, occupying a position similar to that of Cuba.

Events of importance within this period that are not mentioned in this chapter will be found elsewhere in this book under the headings, "Panama Railroad," "French Attempt," "The Church in Panama," "Indians," "The People," etc, etc.

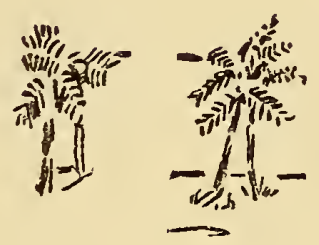




\section{The Presidents of Panama.}

The method prescribed by the constitution of Panama for the election of a President is much the same as that in use in the United States. A popular election is held at which electors are chosen, and these meet during the first week in August and name the President. The first and second vice-presidents are chosen by the National Assembly.

There have been three elections in Panama. The first was an acclamation at which Manuel Amador Guerrero was chosen for the term, February 20, 1904, to September 30, 1908. In the second election there was danger of rioting, and the United States sent supervisors to the polls to exert moral influence for peace. The municipal elections are held the last Sunday in June, and the Presidential, two weeks later. At the suggestion of the United States Government one of the candidates, Ricardo Arias, withdrew, after his party had been defeated in the municipal elections; and the other candidate, Jose Domingo de Obaldia was chosen. Obaldia died in office, March 1, 1910, and that day the second vicepresident, (the first vice-president had died a short time before) Carlos A. Mendoza, became President until the National Assembly met and chose Pablo Arosemena to fill out the unexpired term, October 1, 1910 to September 30 , 1912.

In the election of 1912, the United States Government again supervised to prevent rioting. After the municipal election of June $30 \mathrm{th}$, the candidate of the Patriotic Union, Pedro A. Diaz. withdrew, and Belisario Porras was chosen without opposition. Rodolfo Chiari was acting President. during a vacation taken by Dr. Arosemena, in January, 1912 


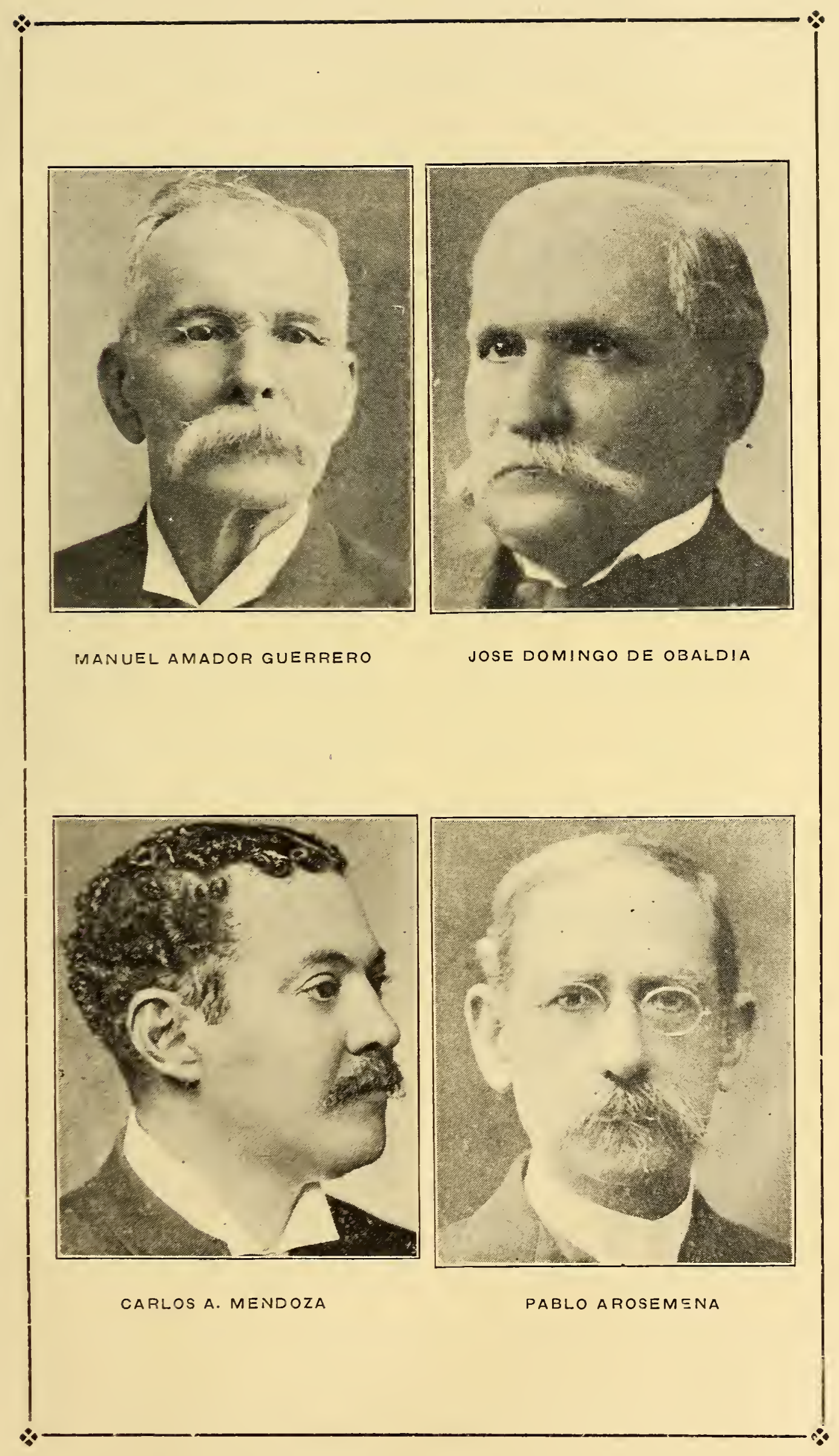




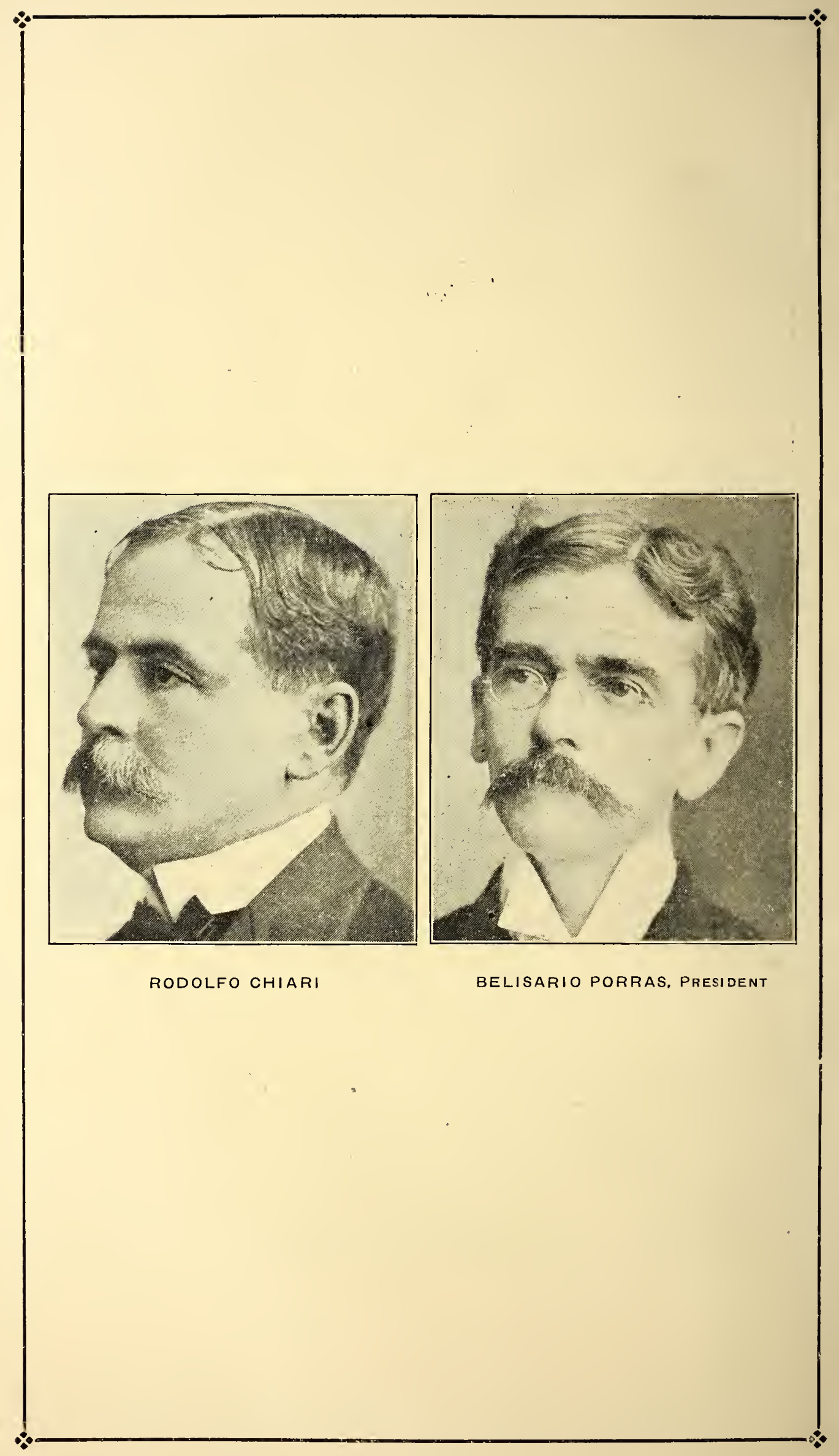




\section{Panama Today.}

The position of Panama is that of a semi-sovereign state, full sovereignty having been renounced in the treaty of February 26, 1904, when Panama agreed that the

Political United States would guarantee and mainStatus. tain the independence of the isthmian state. This status is very advantageous to Panama. because it enjoys all the measure of free government it wishes, and at the same time is free from the primal duty of a sovereign state, that of self-protection. There is no military budget each year to eat up half the revenue of the Government, no temptation to some adventurer to involve the nation in war, no chance at all of Panama's being victimized by some foreign nation. After 1913, the Government of the United States will pay to Panama an annual rental of $\$ 250,000$ for the Canal Zone, and this in perpetuity. Of the ten million dollars received for the sovreignty of the Canal Zone, Panama still has six millions on mortgage drawing an average of 5 per cent. So it is that the annual income of the new government from ou tside sources is actually about $\$ 550,000$ a year, almost $\$ 2$ for every person in the nation. To this may be added the regular governmental income from import and export duties, and other taxation. Panama is distinctly solvent, although her government has not been carefully administered since 1904 . Up to the present time the only interference by the American Government in the internal affairs of Panama has been to insist, in the election of 1908 , that the reference to the voters be as nearly as possible a true plebiscite. The idea is more or less ridiculous because there are not 3,000 men in the whole Republic capable of holding an independent idea of who should be elected. In general there are two theories on which the parties split. The Liberals are strong (in their platforms) for public education and the rights of the common man; the Conservatives are inclined to the aristocratic idea that government should be by the few who know how to govern. One of the traditional rocks upon which the 
parties split was the preference of the Conservatives for the established church, and leaving education in its hands. There is now no danger of establishing a church or throwing the school system into the hands of any sect.

In form the Government is much like that of the United States. There are three branches, executive, legislative, and judicial. The President is chosen for Government. four years and may not be reelected for the succeeding term. The national assembly is chosen for two years, and members may be reelected. The supreme court hears certain cases on appeal, and has jurisdiction over constitutional questions. The executive is divided into five departments-Foreign Affairs, Internal Affairs (Fomento), Education, Law, Finance.

There are seven provinces, each with a governor who has the appointment of the alcades or mayors of the cities and towns in his province. The provinces are Panama, Colon, Veraguas, Los Santos, Cocle, Chiriqui, and Bocas del Toro. The extent and larger towns of each are shown in the map of Panama, in this book.

The greatest length of the country is east and west, a distance of $\mathbf{3 4 0}$ miles from the Atrato River to the range of mountains that separates it from Costa Rica.

Area and Its greatest width is north and south through Natural Fea- Veraguas, 120 miles. The area is approxitures. mately $\mathbf{3 0 , 0 0 0}$ square miles. No accurate map of Panama has ever been made. The best so far published is that issued by the United States Government, corrected by the Panama Government. This map with its chief features shown and with some late corrections is published in this book. Reference to this will show that the streams run in general north and south, indicating the presence of the mountain range that runs the length of the country, paralleling the seacoasts. The range has peaks 7,000 feet high in Darien, and as, much as 11,000 feet in Chiriqui, but there are several passes less than 1,000 feet, the lowest of these being that used by the Canal and railroad, 312 feet above mean tide. In effect the country is a mountain range with a base sloping to the sea, and this base varies in width from a few hundred yards to 40 miles. On this plain or mountain slope are the centers. of population, and the agricultural districts. The climatic changes, rainfall, and similar features are referred to on page under Weather and Meteorology. 
The plains referred to are cut by numerous mountain streams running at steep grade to sea level, and then becoming in general deep and sometimes broad estuaries. In this way were formed the Bay of San Miguel in which a navy could anchor, Montijo Bay, Almirante Bay, Uraba Gulf, and the estuary at the mouth of the Bayano River.

The great number of streams with tidal Water Trans- mouths afford a cheap method of transportaportation. tion. Ships drawing ten feet of water can enter a dozen bays on the Pacific side at high tide, but it is usually necessary to leare at once or wait for another high tide, because at each river mouth are sand bars that can not be crossed except at high tide. On the Atlantic coast the tide has a maximum difference of only 2 feet, and the bays or river mouths are less dependent upon it. A1mirante, Limon, Porto Bello, San Cristobal, Mandinga, and Calidonia Bays can be entered at all times by light draft vessels. Many of the rivers on both sides are navigable for coasting steamers for several miles inland, and the Tuyra takes 8-foot vessels inland a distance of 60 miles or more.

The National Transportation Company of Panama runs light draft vessels along the Pacific coast of the Republic making weekly calls at important ports between David and Panama, and Panama and the Gulf of San Miguel. The more important plantation companies and pearl fishers own their own sloops or launches.

On the Atlantic side one must charter a launch, or take his chances on one of the sloops or launches that are run by private traders. Tugs of the Canal Commission make daily trips to Porto Bello, and the United Fruit ships run weekly to Bocas del Toro. 


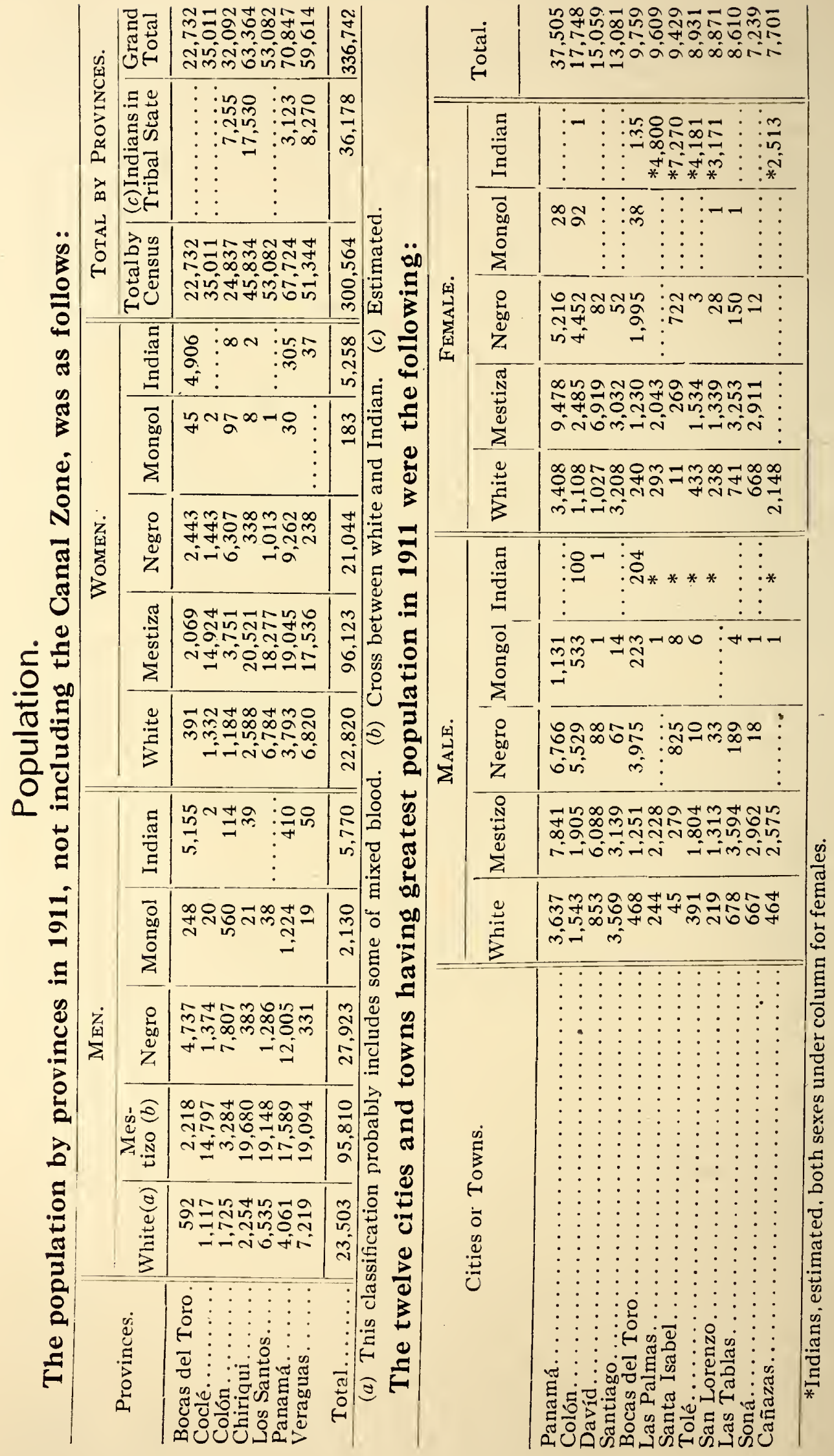


In discussing the population the author of the book on Panama in "Porter's Progress of the Nations" series, writes the following, to which should be added the analysis by Sosa and Arce, to be found on page 121:

The white population is composed of two elements-caucasians and semites forming one, and morenos forming the other. The morenos predominate at least 20 to 1 . Yet the state-

Racial, ment that there are no absolutely white native Climatic, people-that is, caucasian or semite unmixed with National negro or Indians, in Panama, is erroneous. There Influences are at least a hundred families, not alien to the counon People. try, that are white. The morenos are a mixture of white and black, white and Indian, or white and black and Indian. They are among the leading people in education, heredity, physical, and financial fitness.

The white population also includes a foreign colony of about a thousand people all told, including men on ranches and in business in various parts of the Republic. These isolated white men of ten marry native women and thus help to perpetuate the moreno element in the population.

The blacks or negroes are of two classes-the descendants of the native slaves, who probably have some white and Indian blood; and the blacks brought to the isthmus by the construction of the Panama Railroad in 1859 and the canal work. Considering their background they compare very favorably with the whites. In general, their status is still that of the laborer, but some of them have emerged into the artisan and professional classes.

Strongly influencing the lives of the whites and blacks in Panama are the climate and the economic inheritances from Spain and from the trading life of the isthmus. The climate is distinctly enervating. This is true, notwithstanding that the terrors of plague, yellow fever, and malaria are no longer felt on the isthmus. The days are hot and the nights cool, and they are much alike the year around, no great variations occurring as they do in the temperate zones, or in countries where one may go to the mountains for cold weather. Life slips along quietly and without much effort for existence. As a result, one becomes listless. Americans on the canal work are not worth more than half as much as workers after two years on the isthmus as they were upon their arrival.

The economic inheritance from Spain is the attitude that manual work is degrading. This is still the attitude of the young men of the ruling class in Panama, and of course it is not confined to Panama. But it is all right to engage in trade. The isthmian people are traders, and have always been. This penchant for trade only adds to the inherited disgust for actual work, and here alone is sufficient answer to the often-asked question, "Why is Panama still a virgin field for development after four hundred years of caucasian rule?" 
For a brief account in English of the Indians of Panama, the reader is referred to the report of the Smithsonian

Institution of 1909, in which Eleanor Yorke

Indians in Bell has a five-thousand-word monograph

Tribal State. on this subject, together with a bibliography.

The census of 1911 estimates the number of those living in tribal government at 36,178 , divided as follows:

Colon
Chiriqui ...
Panama
Veraguas _...
Total

The Indians of Colon and Panama (the Darien Section). are supposed to be of one family (Cuna), although divided into a half dozen tribes, the most powerful, because most united, being the San Blas of the Caribbean coast. The tribes along the Tuyra and Chucunaque Rivers are less consolidated but share with the San Blas their habit of exclusiveness. On the map of Panama on page 104, the region held by the Indians from which they exclude white men and negroes is indicated.

They inhabit the Caribbean coast from Mandinga Bay to the Gulf of Uraba and from the coast to the headwaters of the streams that flow into the Atlantic. Nominally they are subject to Panama, but like the Indians in tribal state in the United States they pay no taxes, and have their own form of government. They know that the white man would come into their country only to exploit them, and they therefore keep him out. It is not probable that they could or would offer much resistance to an armed force of a thousand men, but they are able to scare away prospectors and the like, and thus, by preventing the white men from makming claims on them or their land, they avoid any excuse for trouble. From early days they have been able to keep their women free from contamination by contact with white men, and to-day they will not permit a white man to sleep in their country if they can readily get him out of it by sunset. Yet these are not hostile Indians. They trade with the whites (practically all the coconuts of Panama are from their groves), sail their canoes down to Colon, where they sell and $\mathrm{kuy}$, and are on friendly terms in general with white men. Only they just won't mix up with them beyond a certain point, just as one might be glad to trade with a fellow white 
man and yet not care to eat with him. In their tribal state they live in towns of well-tuilt bamboo and thatched houses; raise corn, yams, oranges, and other vegetables and fruits; make articles of wicker ware; and weare a cloth of coarse grass.

These were the first Indians the Europeans met in Panama. Balboa got along very well with them, but his brutal followers alienated their suppcrt. They resisted all efforts of the Spainards to colonize in their country until 1637 , when their principal chiefs entered in to a treaty of peace with the authorities in Panama, as a result of which the outposts of Pincgana on the Tuyra, Yaviza on the Chucunaque, and Tacarcuna at the headwaters of the Pucro, were founded. No substantial progress has ever been made in colonizing between the Chucunaque River and the Caribbean coast, howerer. The white men held the country on the south side of the divide with little diffculty, working the mines at. Cana by negro slaves, until 1728 , when a mestizo, Luis Garcia, led them in a revolt that was not crushed until after they had sacked all the towns of the Darien and massacred the inhabitants. Until 1741 the Indians of Darien were at war with the Spaniards, and then they made peace, the Spaniards returning to the mines and the fields. This peace was only with the tribes south of the mountains, however, and even among them there were many hostile families. A few years after peace was made the Jesuits attempted to evangelize in the Darien, but few Indians would listen to them. One kind or another of missionary has been at them ever since, but they'd rather not, thank ycu, save their souls at the ccst of their lands.

The Indians of Chiriqui and Veraguas are said to be of two distinct families,-Doracho-Changuina, and Guaymi. The former inhabit the mountains near the Costa Rica border, and have little power. The latter make their homes in the mountains of Veraguas and eastern Chiriqui, and, although they trade with the whites, exclude them frcm their territory. Bell quotes Valdes as saying:

"The Guaymies live in groups for the most part in the high Valle de Miranda in the Cordillera of Veraguas, cut off from communication with the plains by defiles difficult of access. They have retained their independence, having warded off invasions of both blacks and whites; who can not penetrate their land without permissicn of the powerful chief. Some families seem to be descended from those 
who, before the arrival of the Spaniards, carved symbolic figures on the rocks of the mountains and placed gold ornaments in their graves. In former times they were, without doubt, more civilized; but modern progress has destroyed their industries, as they now provide themselves with arms, tools, utensils, clothes, etc., from their neighbors, which formerly they made themselves."

A custom of these Indians was to bury with a prominent warrior his ornaments, cooking utensils, weapons, wives, and slaves, and to this custom is due the presGold images ervation until this day of many of the ornaand Pottery ments and utensils, known commonly as the of Chiriqui. gold figures and pottery of Chiriqui. The grave was built with a large space in which the corpse and its attendants and utensils were placed; over this was laid a slab of stone, and this in turn was covered with rock. The burials were made in definite sections, and the method of detecting a grave today is to go over one of these sections prodding into the ground until the iron rod, with which one explores, strikes a stone slab. Excavation at this spot usually reveals an old grave with its pottery utensils, and frequently with gold ornaments. The pottery is unglazed, but some pieces are decorated and curiously molded in crude imitation of familiar animals. A good collection of this pottery is in possession of Mr. Paul S. Wilson of Ancon, while John Ehrman, the Panama banker, owns the best collection of gold images.

The public-ischool system has been improved every year since the formation of the Republic, and it is a distinct credit to Panamans in general that no gov-

Schools. ernment could maintain itself in power if it did not continue in this course of improving and expanding the system of public education. At present the schools are in two classes, primary schools maintained in all the villages, and secondary schools in the chief city of each province. The census of 1911 shows that out of 240,609 persons (uncivilized Indians not included) over six years of age in the Republic, 68,019 know how to read and write, 170,792 are illiterate, and the balance know how to read but not to write. If the present interest in education keeps up the figures quoted will be reversed within ten years. 
The number of children of school age ( 7 to 15 years) in 1911 was 60,491 and the school statistics were as follows:

\begin{tabular}{|c|c|c|c|c|c|}
\hline \multirow[t]{2}{*}{ Class of School. } & \multicolumn{3}{|c|}{ Number of Schools. } & Number of & $\begin{array}{l}\text { Number of } \\
\text { Teachers. }\end{array}$ \\
\hline & City. & Rural. & Other. & & \\
\hline $\begin{array}{l}\text { Public primary .......... } \\
\text { Public secondary . . . . . } \\
\text { Private primary } \ldots \ldots \ldots \\
\text { Private secondary } \ldots \ldots \ldots\end{array}$ & $\begin{array}{r}120 \\
20 \\
2 \\
3\end{array}$ & $\begin{array}{l}\quad 52 \\
\ldots \ldots \cdots \\
\cdots \cdots \cdots \\
\cdots \cdots\end{array}$ & \begin{tabular}{l}
\multicolumn{2}{c}{69} \\
$\ldots \ldots$ \\
$\ldots \ldots$ \\
$\ldots \ldots$
\end{tabular} & $\begin{array}{r}16,104 \\
1,263 \\
868 \\
372\end{array}$ & $\begin{array}{r}450 \\
85 \\
54 \\
36\end{array}$ \\
\hline Total...... & 145 & 52 & 69 & 18,607 & 625 \\
\hline
\end{tabular}

A normal school in which girls are prepared for teaching had 116 students in 1911 over 14 years of age. A national institute erected in Panama City in 1911 has been opened. It has seven large buildings providing for dormitories, eating-rooms, class-rooms, and laboratories. It is proposed to make this the head of the national system, the idea being that any pupil in the Republic who qualifies for the higher courses may have four years of instruction here at the expense of the Government. A faculty is being assembled under the direction of an American of university training. At present the best schools are private institutions in the cities of Panama and Colon, two Catholic secondary schools, one Methodist, and two for the children of wealthy parents.

A Government trades school, where in a 3 years course boys are taught the elements of machinist's, carpenter's, and other trades, is conducted in the city of Panama with over 100 pupils.

As part of the system of public education there is maintain ed a good school of music in the city of Panama, a national band in the same city, and a National Theater, likewise, in Panama, where good plays and operas are staged by professional players, and public meetings of a nonpolitical nature are held.

There is nothing more tragic in the history of Panama than the part the church has played, because it has done so much good and yet by an unnecessary The Church. mixing in finance and politics has cut itself off from doing as much as it is capable of. In the beginning, the Spaniards sent to America thousands of soldiers of fortune, gold hunters, criminals, brcken-down courtiers-everything but honest working men; but the church sent its best. Las Casas-idealist, dialectician, poli- 
tician, kindly man,-was only one of a class of strong, noble missionaries who came to America to convert the heathen, neither asking for nor receiving money reward. (Most of these men were of the regular clergy who are not allowed to hold property). From the beginning they were the friends of the Indians, worked hard to have the laws against slavery of Indians enforced, and even yielded to the expedient of introducing negro slaves for the purpese of saving the Indians. In a lawless, ungodly, uncultured community, the church stood for order, respect for authority, and the obligation of those in authority, and for whatever refinement there was. The Jesuits, Franciscans, and Dominicans were all teachers, and for three centuries their schools were the only ones. To be sure, the church had a monopoly of education; but, on the other hand, it alone seemed to care for the monopoly.

Titles were never secure in the colonial days, nor have they been since, for that matter; but the church property was never forfeit, nor could it escheat. So the church as a property-holder became irresistibly strong. By the end of the period of the Royal Audience in Panama, the church owned most of what was worth holding. It paid no taxes yet it levied taxes for all the ministrations without which Roman Catholics can not live or die. As a property-holder it naturally identified itself with the established order, and therefore became identified with conservatism. When the revolutionary movement came, the church as a holder of property and a conservative force was one of the principal objects of attack. Between 1821 and the present time, over half of the church property in Panama has been confiscated. It is a comment on the futility of the system of changing title from one private person to another, that the church property has fallen into the hands of people who are holding it for exorbitant prices, not even improving it, for the lack of a land tax in Panama permits this.

Notwithstanding that it has compromised with property, the church must be credited with having been the seedbed for education and culture in Panama. It maintains churches in all the large villages, has missionaries among the Indians, conducts schools for boys and girls, and runs the orphan asylums. It has failed of realizing the best that is in it, but it has come far from absolute failure. See also page 164 . 


\section{Resources of Panama.}

Panama holds out bright prospects of large returns for intelligent investors. It would appear, however, that there are very few of this species coming to the Isthmus, because most of the people who talk of development expect to get fifty per cent returns in a few years. Of course such ideas are wild. For men who are willing to invest their capital in conservative enterprises, however, and wait for good returns for several years there is an attractive field.

The first obstacle to be overcome is the perfecting of title. Government grants are always good, but the best lands are held by private persons, whose title Land Titles, in turn is usually clouded. The method emTransporta- ployed by a local business man in a recent tion, Labor, purchase of a large tract was to buy the property

Banks. from the supposed owner, then to go over the land and buy up from the squatters upon it their rights. In this way he has a title that is good against anyone but the Government. Having procured the land to be developed one must find means of making it accessible. Trails must be built, and this work is expensive in a country where the heavy rains wash out the roads and the rank vegetation rapidly closes trails. Land near water is always desirable, but in Panama it is necessary because there are no railways into the interior and the main highways are usually poor, in general they are merely pack trails. Fortunately navigable bayous penetrate the Isthmus on both sides. The labor market, which was very high during the height of construction on the Canal, is becoming normal again, and it will soon be possible to employ West Indian negroes at rates only a little in advance of those paid in the West Indies. Native labor is no good for steady work, except in clearing. The natives are good bushmen, but they will not pin themselves down to farming; and even if they were willing their number is exceedingly limited. For development on a large scale imported labor is necessary. There are good banks in Panama capable of handling any class or amount of business.

The greatest single industry in Panama at present is the banana growing on the plantation of the United Fruit Company at Bocas del Toro on Almirante

Bananas. Bay. Over four million bunches of bananas were exported from this plantation in 1911 , 
35,000 acres of land are under cultivation, and the Company maintains a narrow gage railway system, docks, stores, and steamships in its Bocas del Toro business. Prior to the war of 1898-1903 bananas were grown quite extensively at points along the Panama railway, and throughout the interior, but the fighting took the men from the fields, the weeds grew up, and when peace came again the Canal work drew upon the country people for labcr. Bananas can be grown in any part of Panama. There have been projects within the past few years for opening banana plantations for the purpose of supplying the Pacific coast markets, where the United Fruit and other large fruit companies have not made much effort; but they all appear to have lacked backing. It requires a lot of money to develop banana growing to such a point as to justify the maintenance of ships for handling the product. Besides the United Fruit Company the only other banana enterprise under way just now is that of the Boston-Panama Company on its big plantation on Montijo Bay.

Panama coconuts are the best on the market, that is, they command the most ready sale, bring the best prices, and are highest in oil content. Most of those

Coconuts. exported at the present time come from the San Blas coast where they are raised by the Indians, although a few are exported from the shores of Chiriqui Lagoon. Panama is fortunate in being outside the hurricane belt so that trees once come to maturity are in no danger of blowing down, as those in the West Indies and along the coast of Central America are. The development of this industry is under way in a number of localities, among them Nombre de Dios, where a Colon merchant is setting out fifty thousand trees; Almirante Bay, where a grove of a hundred thousand trees is being planted; Venado on Panama Bay, where a grove of fifty thousand trees is being set out; Montijo Bay where a grove is being planted, and at Remedios where trees are growing. There is much available coconut land along both coasts, but one must buy it, there is no Government land worth while within sight of the water, and coconuts need the salt breezes. A coconut grove will come in to bearing five years af ter the sprou ts are planted, and after that each tree should be good for a clear profit of one dollar a year. The cost of planting a grove of ten thousand trees and bringing it into bearing is estimated at about three dollars a tree. 
Ivory nuts grow wild in sufficient number to pay for gathering them all the way from the Cocole River to the Atrato. The chief export at present is from the Ivory Nuts. San Blas coast where they are gathered by the Indians, and from the Garachiné region near San Miguel Bay. Throughout the Darien ivory nuts are collected by the natives. Tre Panama nuts are not the highest grade, but in 1912 those gathered on the Duque estate on the upper Bayano River were so large that they commanded the top price. No attempt has been made to systematize the growing of the trees, and most of the nuts are collected without special system, although trails have been made at Garachiné and on the upper Bayano. The expcrts amcunts to about two million kilograms a year.

The native rubber of Panama (Castilloa Elasticus) is gathered in practically every part of the country, the majority of it at present coming from Darien. The

Rubber. Boston-Panama Ccmpany has been tapping a hundred thousand trees on its large estate on Montijo Bay for the past four years, and turning the revenue therefrom into the development of the plantation, which comprises 400 square miles and will be set out in bananas, pineapples, coconuts, and other tropical fruits and plants. An experiment in the growing of Para rubber is being carried on at this place, and the indications are that it will succeed, although it is too early to say this with surety.

Coffee grown on the tablelands of Chiriqui is as good as the best Costa Rican, and it is probable that it could be grown with considerable profit in view of

Coffee. the present high prices for coffee. Not enough is grown at present, however, to supply even the local market, although there is a good demand for the native product.

There is only one large cacao plantation in Panama, the Preciado estate near David, in Chiriqui, where 58,000 trees are bearing. This is the cnly scientific atCacao. Sugar. tempt that has been made to raise cacao and it has been so successful that trees are added every year. For several years past this cacao brought the kest price on the London market.

There is no part of the Republic in which sugar crne can-. 
not be found growing to great height. Tests show that this cane is high in sugar matter. Two plantations are being set out along the north coast of the isthmus, one near Chiriqui Lagoon, and the other near Porto Bello. By 1915 these experiments will have been carried far enough to afford reliable information as to the possibilities of sugar raising in Panama. This industry requires a large capital and extensive operations.

Oranges, limes, sweet lemons, pineapples, mangoes, papaya, mamei, nispero, sapodilla, Panama cantaloupes, guava, and other tropical fruits grow pro-

Fruits. fusely, but no effort has yet been made to cultivate them extensively. In its report on agriculture in the Canal Zone (1911), the Department of Agriculture says that the steep side hills of Panama are well adapted to the growing of citrus fruits, in connection with other farming; that is, that the hills which are too steep for ploughing could be utilized in this way. The pineapples of Taboga Island have a good local reputation. They are large and delicious and command a ready sale.

Garden products, such as beans, radishes, lettuce, and the like are grown chiefly by the Chinese in and around the larger settlements. A model garden of Garden this kind is that situated alongside the SabVegetables. anas road in the Calidonia section of Panama city. The supply is not sufficient for the local market. Intensive methods and cheap labor are used by the Chinese. It is not believed that truck gardening as an independent industry would pay in Panama.

The cutting of hardwoods and other timber in Panama is in its infancy. There is no hardwood along the line of the Canal and railway, except a stick here and there.

In developing the hardwood resources of the country only experts in this line should be depended upon. No money should be invested before the investor has Cabinet gone over the land to be developed, and deWoods. termined how much timber there is, and what the facilities for moving it to a navigable stream are. The hardwoods of Panama are many and good, but the trees grow in isolated places and not many in an acre, so that the felling and carrying to market are expensive. The beautiful native mahogany, so much used in the city as flooring and in cabinet work, costs from $\$ 80$ to $\$ 100$ a thousand board feet, and the amount available at this price is 
small. A small quantity of this mahogany is exported. The best timber is reputed as being along the Bayano, Chucunaque, and Tuyra rivers and their branches, and most of this land is already held by development companies. Sawmills have been erected in various parts of the Republic, but the companies seem to be waiting for the opening of the Canal before placing their product on the market, the prices for freight over the Panama Railroad being very high. Elsewhere in this book reference is made to the door of the Municipal Building in Panama as affording a good illustration of the various native cabinet woods. There are a number of small cabinet shops throughout the city where these woods may also be seen.

The local demand for meat is supplied almost entirely from cattle raised in the country. This does not take account of the cold storage meats imported for the Cattle Canal workers. The cattle are allowed to Raising. fatten on the grass grown in cleared places, no grain being fed to them. The meat is good. The project of erecting an abbattoir near one of the entrances of the Canal, and operating a cold storage plant for the supplying of meat to passing vessels has been broached, but no steps in this direction have yet been taken.

Every stream in Panama shows colorings of gold, yet few of them are worth working by the ordinary panning method, the long rainy season interfering

Minerals seriously with this class of operation. In every province of the Republic there are sections where gold was mined with profit by the Spaniards, but they used slave labor, and the methods by which they worked the diggings were not profitable when slavery was abolished. Various prospecting companies have sent engineers into various sections of the country, and in almost every case the report was to the effect that the ore was good, in some instances even excellent, but the cost of development, including transportation inland of machinery, was too great to warrant operations at the present time. In the Darien region, where formerly the Spaniards worked extensively at Santo Domingo, Cana, and other points, only the Cana mines are now operated. They pay a good interest on a small investment. The closed country for the Indians in Chiriqui, Veraguas, and the San Blas region of Colon is said to be rich in gold but your guide ventures the opinion that this is because no one knows, and every one likes to 
place in the "closed country" great riches. Copper is found in Los Santos, and both copper and nickle in Darien. Inquiries with regard to denouncing claims should be made at the office of the Secretary of Fomento in the National Palace.

\section{Pearl Islands and Fisheries.}

The Pearl Islands, an archipelago of 60 islets, lie in the Gulf of Panama about 60 miles south of Panama city. It was these islands that Balboa saw from the Pacific shore of Darien, and Rey Island, the king of the group, he named Isla Rica. From here Pizarro took back to Acla the basket of pearls, later he outfitted here for one of his voyages in search of Peru. Except as a stopping place for ships enroute from Peru to Panama in the old days, the islands have little historical interest. Today they are inhabited by negroes and morenos, and a few Chinese who run the stores. San Miguel, the largest village, is situated on the side of a hill on Rey Island overlooking a pretty bay, which becomes a mud flat when the tide is out. It has a church, a school house, half a dozen small general stores, and a few saloons. The population is 700 , and the village is the seat of an alcaldia. It is a stopping place for the steamers that run to Darien. Saboga, on the island of that name, is a clean little village situated on a bluff overlooking a bay that can be entered at all stages of the tide. It has a church, school, stores, saloon, and 300 inhabitants.

The pearl fisheries are the principal industry. Schooners outfitted in Panama carry on this work, and the oysters are taken by men who work in diving suits. No value can be assigned for the pearls because they are carried out in small parcels. The pearls are of two kinds, white, and black, and here as elsewhere they are valued according to their perfectness of shape and coloring. Some of the natives dive naked for the pearls, but their product forms a small part of the total. For information on the pearl fisheries the reader is referred to an article by $\mathbf{C}$. M. Brown in The Bulletin of the Pan-American Union.

A trip to these islands may be made by launch in six hours, eight hours to San Miguel, from Panama city. One who is in search of natural beauty cannot spend two days better than in a cruise about the archipelago. 


\section{Gocos Island Treasure.}

Cocos Island lies at the entrance to the Gulf of Panama 300 miles south of the city. It is the place where $\$ 7,000,000$ worth of treasure stolen from Callao, and $\$ 3,000,000$ worth stolen from Mexico between 1820 and 1830 are said to be hidden. Many expeditions have searched for this treasure, and two men are said to have found some of it. The whole story is told in the book, "On The Track of a Treasure", by Harvy Montmorency. Since that book was written four expeditions have made the attempt, two of them by Lord Fitzwilliam, whose second ship is now the Chame of the Canal service at the Pacific entrance. A hydraulic mining company of Seattle is now preparing to wash the treasure out of its hiding place.

\section{Taboga Island.}

Of the dozen islands in the Bay of Panama only Taboga is inhabited. It was set aside as the dwelling place of liberated Indian slaves in 1549, and its people, 850 in all, are chiefly the descendants of these Indians mixed with negroes. The island is an extinct volcano whose steep sides come down to the water's edge, leaving only a little shelf or terrace on which the village stands. The houses are for the great part substantial stone and adobe buildings. There is a church with a bone of a real saint, a school, half a dozen saloons, and half a dozen Chinese shops. Raising pineapples, fishing, and dealing with the convalescents from the sanatorium are the chief sources of livelihood.

The sanatorium is a large frame building erected by the French as a convalescent hospital, and maintained as such by the Americans. There is little rain in Taboga, even in the rainy season, and the cool dry air is very tonic for people from the mainland.

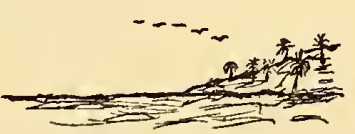




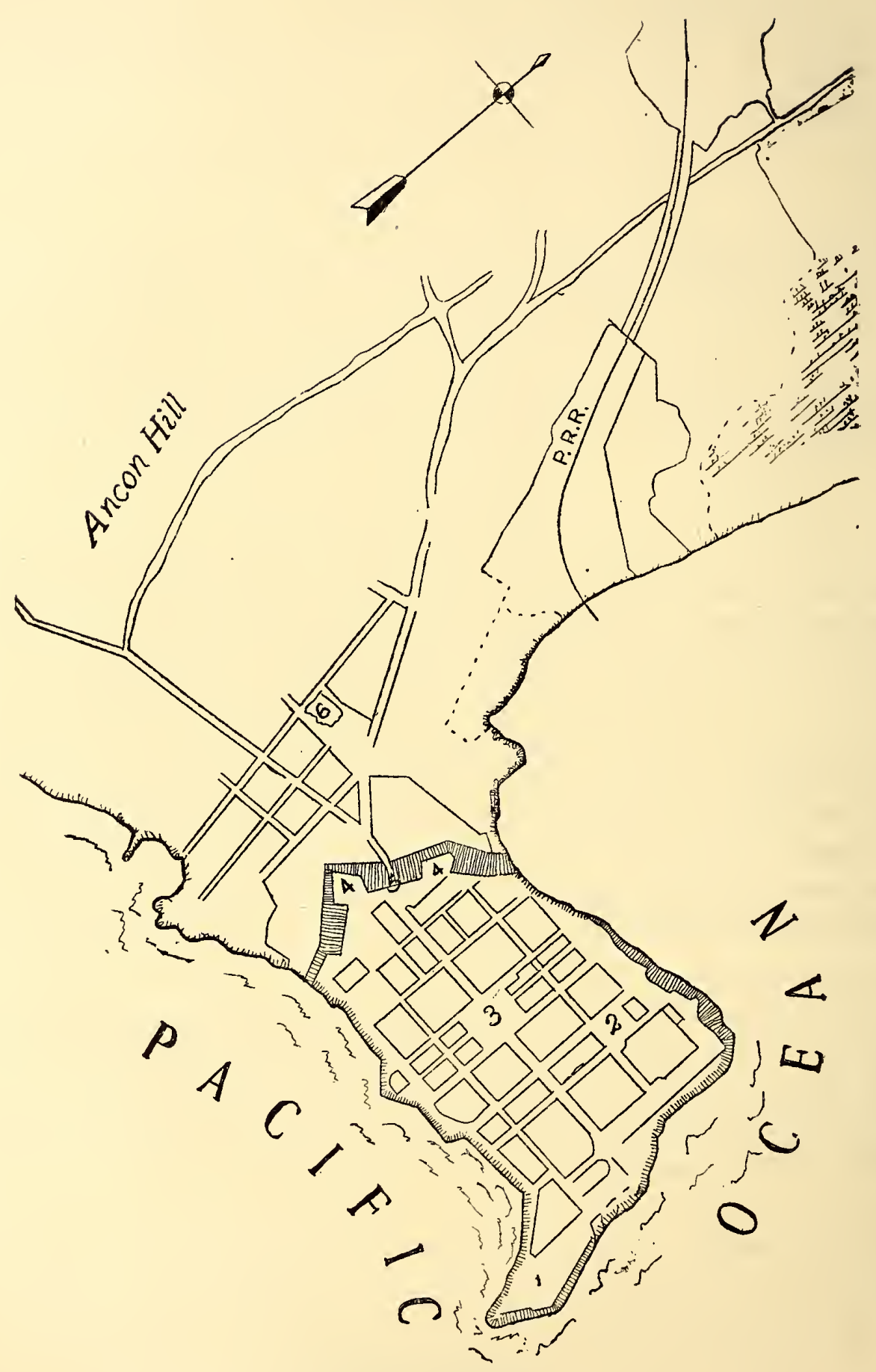

PANAMA CITY IN 1857.-Hatched lines show old wall.

(1) South bastion, Barracks and Prison. (2) Plaza San Francisco (Bolivar). (3) Plaza Independencia (Cathedral). (4) Bastions of Old Wall. (5) Gate and Drawbridge. (6) Santa Ana Church 


\section{The City of Panama.}

The new city of Panama dates from Saturday, January 21,1673 , when, in the presence of all the dignitaries of Terra Firma, the Bishop marked the site of the cathedral with a cross, and blessed the place where the new city was to be built. The following year the plans for the walls were completed. Along the sea was built a wall, still standing, from 20 to 30 feet high; across the peninsula, as shown on the map, page 150, another was was built to guard the land side. A drawbridge was thrown over a deep moat that was filled with sea water. It was planned to make the city proof against such raids as Morgan's, and this was accomplished. Two bastions commanded the land side, and one the sea approach. It was cheaper to carry rock from the ruins of Old Panama than to quarry it on the tidal flat, and much of the stone in the walls and older churches was brought from the old site. Private residences were built of wood.

Unchecked fires swept over the city in February 2, 1737; March 21, 1756; April 26, 1781; March 7, 1878; and June $13 ; 1894$. These burned everything in their

Fires. path; that of 1737 consumed two thirds of the 911 buildings inside the walls; that of 1756 burned the convents of Santo Domingo, San Francisco, and the church of San Felipe Neri; that of 1781 the Jesuit convent and 56 houses; that of 1878 half of the city within the walls, and that of 1894 the whole north side of the walled town, consuming 125 buildings. So it is that there are few old buildings in the city. The masonry buildings that have replaced those of wood are of such style, their walls weather so quickly, and they fit in so well with the really old buildings, that one gets an impression of age, which is in fact one of quaintness.

In 1793 , the total population of the isthmus was 71,000 , not including uncivilized Indians. Of these 7,857 were inhabitants of Panama. In 1870, the census

Population. gave Panama 16,106 inhabitants. The directory estimate of 1896 placed the number at 24,159 . The census of 1911 gave 37,505 . 
Electric lights were installed in Panama in 1891. As early as 1890 the plan to bring water to the city from the Juan Dias River, about eight miles outside Water Sewers, the city was approved, and there was conPavements, fident expectation that this would be done. Lights. But the unsettled political conditions, and the almost total suspension of the Canal work made the undertaking too expensive. The old method of catching water in cisterns during the rainy season, and using it, eked out by water peddled from door to door by the water vendors who caught it in nearby brooks or took it from wells, was continued until July 4, 1906, when the present system first delivered water. This water is carried from Rio Grande Reservoir near Culebra, on the top of the divide, to Panama in a 20-inch main (until 1912 an 8-inch main), and the same supply suffices for the Canal Zone villages between Culebra and Panama. Every street in the city has a sewer connected with trunk sewers which empty into the bay beyond low-tide mark. Every street is paved with brick or macadam, and all are well drained. The dirtiest slum in Panama is much cleaner than some middle-class streets in large American cities. All the street, sewer, and water improvements are being paid for by Panama from its water rates. The money for the installation represents a loan from the United States on which interest is paid. There is a well organized fire department equipped with automobile fire engine and hose truck.

Most visitors enter Panama city from the north-that is, by way of the railroad, and the guide assumes that their acquaintance with the place will begin at that

New Section end. By reference to the maps showing the of the City. city in $\mathbf{1 8 5 4}$ and again at the present time, one can see which is the old and which the new sections, and it is evident that the northern part is very new. In fact, is it a creation of the canal-building days. There was no room for much expansion within the walls of the old city, so the new buildings necessary for the larger population were erected outside the walls. To the French period belong the cafes around Plaza Santa Ana, with their boulevard drinkking places; and to that period and the American belong all the other buildings, except the church of Santa Ana itself, to which reference will ke found on page 170 .

In front of the railway station, which is soon to be replaced with a concrete building in Spanish mission style, 
is a triangular plat of ground used as a playground. It is called Railway Plaza at present. On the city side of this plaza is a large three story, fireproof building completed in 1912. It is the International Hotel, and is fitted up with all modern conveniences.

Between the railway station and the Hotel Tivoli is an open square called the Plaza de Lesseps. It is laid off prettily in walks converging at the center, where

Plaza de there is a tool house, evidence that the work Lesseps. of improvement, begun in 1909, is still in progress. The rather ragged condition of the grass plats is due to the fact that grass grows very rank during the rainy season, and it would take a dozen men under the direction of an expert gardener to keep this one plaza in condition. Some day there will be erected in the center of this public park a statue to Ferdinand de Lesseps, a power lawn-mower will be continually at work, and the quick-growing palm and royal poincianas will shed a generous shade.

Northward from the park, across the bridge that spans the railway tracks, are the suburbs of Santa Cruz, San Miguel,

Pueblo Nuevo, Calidonia, E1 Trujillo, GuachaCalidonia and pali, Maranon-all tiny settlements that Other Suburbs. gradually expanded until they merged into one. Recently this section of the city was paved with macadam, sewers laid, and water mains put in; so tha tall it needs now to make it a desirable place of residence :s a brisk fire, a strong wind, and some good neighbors. The tourist will pass through a part of this section on his way for a drive out the Sabanas Road, or going to Old Panama.

The general direction of Central Avenue is north and south until it reaches Plaza Santa Ana, when it turns almost east and west, its direction through the old city. On the way to this plaza, half the distance between there and the railway station, you pass on the right side of the street a three-story concrete building painted white, and with a broad concrete portico extending out upon the sidewalk. This very ornate structure, said to be of the late renaissance period in northern Italy, is the clubhouse of the Spanish Benevolent Society. Right next door to it is the American consulate. Two blocks farther is Plaza Santa Ana, so named from the old church that faces upon it, the most interesting place outside the limits of the old city. 
Here up to the middle of the old French times was a wide open field, around which seats were built on the occasions of great festivals, like independence

Plaza Santa day, when bull baiting and other popular

Ana. games were played to make the people glad that they were free. Twenty years ago the square was improved, trees and plants were set out, the walks made formal, and benches placed. The more recent improvements, such as paving with tile, tearing down the iron fence that surrounded the park, and building the pretty concrete benches along the margin have been made since the American occupation. On Thursday nights there is a band concert in this plaza, and then hundreds of people, mostly brown Panamans, with a few Americans, promenade. It is a pretty sight.

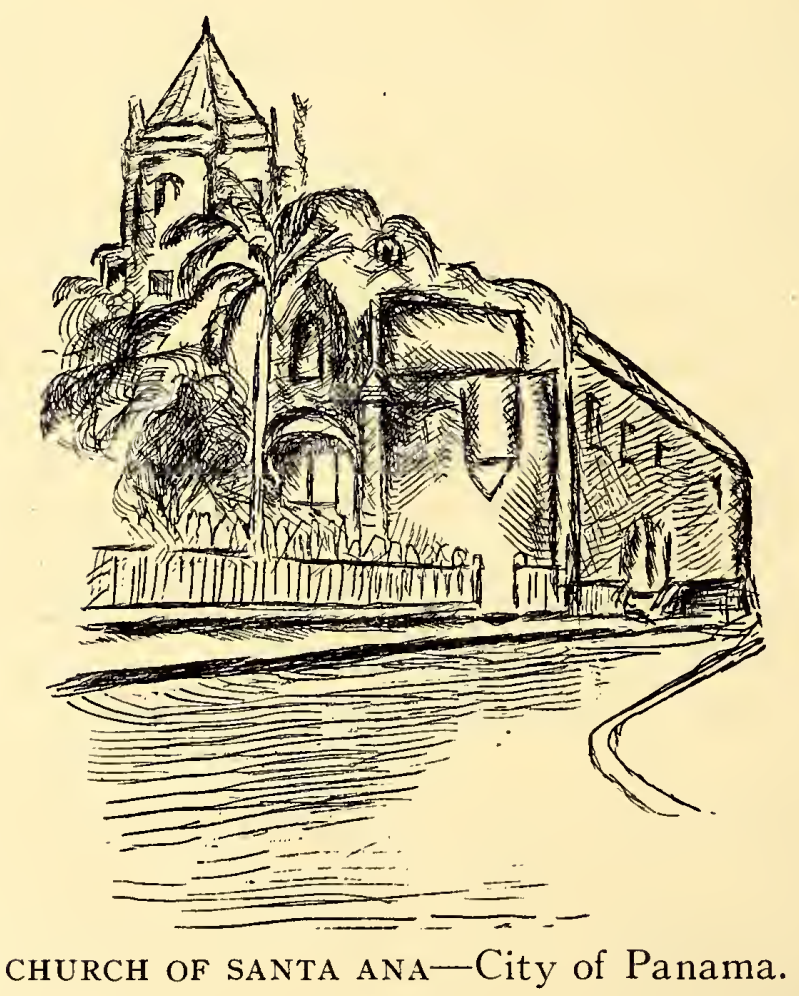

On the east side of the plaza is the Hotel Metropole, with a balcony from which one may watch the motley crowd in the park. On the north side is the Panazone, a saloon whose name is its chief novelty, composed as it is of the first two syllables of Panama, and the last word of Canal Zone. On the south side are two saloons and restaurants, hold-overs from the French days, and the Theatre Variedades erected in 1911-1912. Church of Santa Ana page 170 . 
On either side of Central Avenue outside the limits of the old city are residences and small shop buildings. On the road that extends from one block south Hospital, of the Plaza Santa Ana westward to Balboa Cemetery, are the Santo Tomas Hospital, rejuvenated Restricted since 1904, and the cemeteries. The hospital

District. has 350 beds, is under the direction of an American doctor, and has a good staff both of physicians and nurses. It is maintained by the Government of Panama, but the United States Government has representatives on its board of directors. Americans injured in Panama are taken direct to Ancon Hospital.

There are three cemeteries-one for Chinese, one for Hebrews, and one for Christians. The Christian burying. ground is held on concession from the Government, and space for burial is leased on time leases. There are interesting monuments here telling a story of the mixture of many races, and giving some insight into the tragedy of the first canal builders who succumbed to fever in the early' French days.

Between the hospital and the cemeteries is the restricted section of the city in which, under surveillance of the authorities, live 130 women engaged in the profession of public prostitution.

Going down Central Avenue from Plaza Santa Ana, three blocks below the latter place, one comes to the Church of La Merced, dedicated to "Our Lady of

Gate to Old Mercy." This church is used here only for City. a landmark; it is referred to on page 169. Diagonally across from La Merced, alongside the drug store, is a piece of the old wall that ran across the back of the city, from tidewater on one side to tidewater on. the other. It is worth going over and climbing up the steps, for in this way one gains an idea of the size of the walls. whose great price caused even a King of Spain to wonder. This piece of wall was one of the two bastions that commanded the drawbridge across the old moat, and likewise the sabanas on the north of the city. By reference to the map of the city in 1857 , one can see how entirely these two salient points commanded every part of the plains outside. The youth of Panama.play tennis on the old bastion, and there once a year a traveling circus, with its clowns and other glories, makes a one-week stand. 


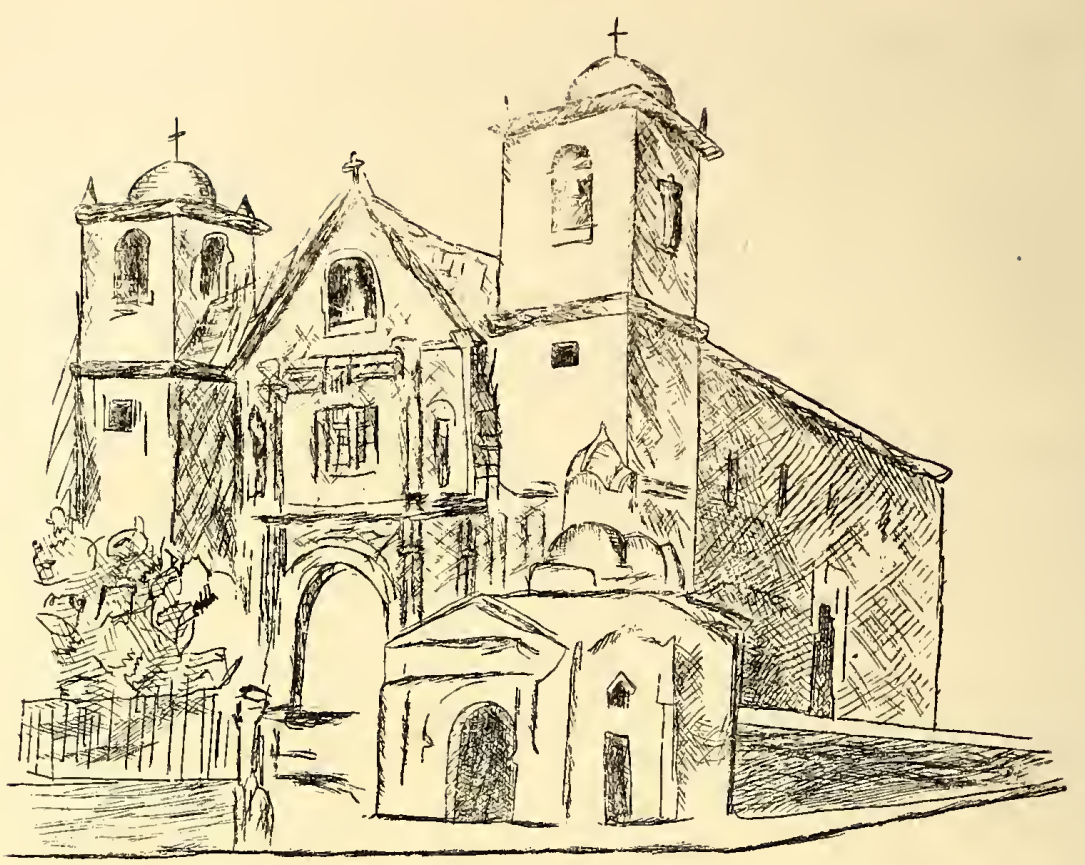

LA MERCED-PANAMA CITY.-(Church of Our Lady of Mercy.)

It has an area of at least 15,000 square feet, and from the top there is a sheer drop to the level of the country outside the walls of from 30 to 35 feet. A parapet three feet high still stands there, in places showing the embrasures for the brass cannon that were mounted on the top of the castle. There remains enough of the old wall running from the castle to the sea on the south side, to show that it was formed of two rock walls filled in between with earth, and that there was room on top for a cart to pass.

Within the old wall is really Panama. Outside are some Panamans, but mostly aliens; within are a few hundred aliens among the many Panamans, but the spirit of the old place is also there,-in the narrow streets, the old plazas, in the churches, on the sea-wall, in the homes, -an indescribable something that one must not let lay hold of him, because it will never let go. "They' always come back," is said of people who leave here for a while; and this is the verbal expression of the spirit's power. Three blocks from the old city gate one comes to the point from which the city was laid out, the central square.

The Plaza Independencia (Cathedral Plaza, or Central Park) is the heart of Panama City, and has been for nearly two centuries and a half. On that morning

Central Plaza. in 1673, when the Bishop of Panama knelt and drew on the ground a cross that must mark 
the corner of the new cathedral, the life of the plaza tegan. Quite likely the men who watched the ceremony walked aside to the shade of some friendly tree when it all was over, lighted their cigarettes, and talked about the chances of the new city in the place where now the men of Panama congregate to discuss the politics of the day. From this

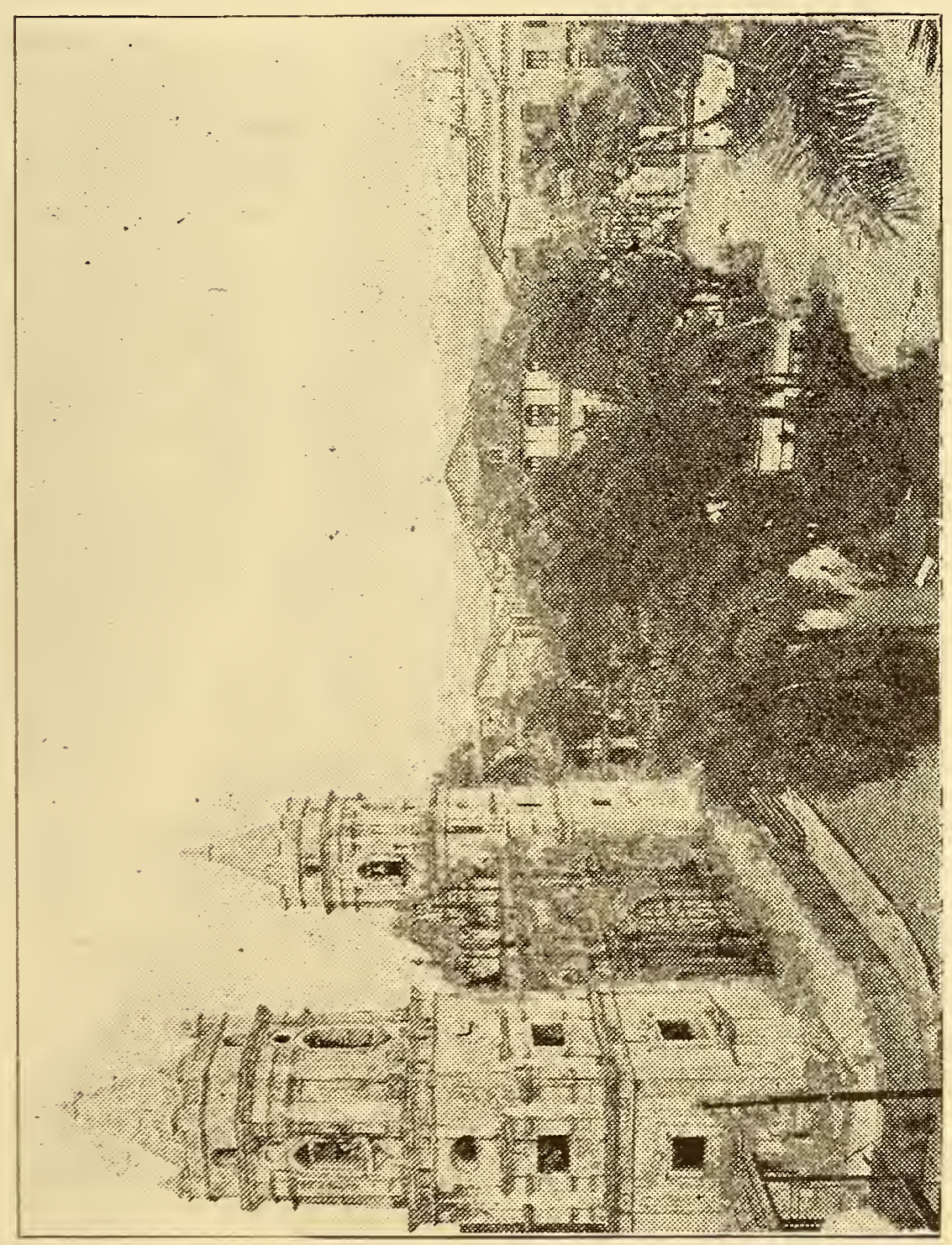

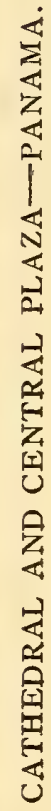

center run cut the main streets of the old city-Avenida Central north and south; and 5 th, 6 th, and 7 th Streets east and west. On the north side is the cathedral to which reference is made on page 166; on the south the Hotel Central; on the west the new municipal building, and the old Canal administration building; and on the east the Bishop's palace and the office of the lottery. 
The Administration Building of the French Canal days was built in 1875 as a hotel, in the style most common in Panama-in fact, the Spanish style, a rectang-

Canal Office ular building four stories high, around a patio

Building. or court. After a few years as a hotel it was leased by the French Canal Company and was used as the main administrative building, and from this office, as now from Culebra, the Director governed his construction community. The Americans came into possession of it on May 4, 1904, when they took over the effects of the French. Canal Company, and immediately it was made the administrative headquarters. During the yellow fever epidemic of 1905 the building was found to be infested with Stegomyia mosquitoes, and fully half the cases contracted among American employees could be traced to this building. It was abandoned as headquarters in 1906, when the Chief Engineer moved his office to Gulebra. At present it is occupied by the health and municipal offices of Panama, and by the Panama government printing office.

The municipal building, the handsomest in the city, was completed in 1910, and occupies the site of the old "cabildo" or town hall in which independence

Muncipal was declared in 1821. It contains the municiBuilding. pal council chamber, and other offices, and the Columbus Library, a collaction of over 2,500 books. Here can be found works in Spanish that throw light on the history of Panama. The front door is made up of a dozen different native hardwoods carefully joined and polished. This is worth a study on the fart of anyone interested in cabinet woods. In the corridor is a marble statue of a bacchante. Highbrow people look at this intently and say- "Ah, very good, very good," so it is probably a good piece of work. There is nothing suggestive about the bacchante being in the corrider of the municipal building, because the police court is held several blocks away.

The Hotel Central is another example of the Spanish type of building around a large central court. It is four stories high and was built in 1880 , but has

Hotel been renewed during the past few years. The

Central. rooms are airy and clean. To the tourist it is most interesting as a coign of vantage from which to view the varied life of the city. Instead of the summer resort crowd that one finds at the Hotel Tivoli he sees here 
Latin-Americans, in its cafe political partisans always discussing what may happen, and in the patio on Sunday night, while an orchestra plays, the most vivacious scene to be found in Panama, for here people of half a dozen nations congregate to gossip and sip their drinks and watch one another. From the balcony one may look on at the life of the Plaza, whose most characteristic scene is that of the sunset hour when the men of the city make little groups upon the park benches while they gossip and smoke a friendly cigarette. At night it is more quiet, but not less interesting, for there are always people sitting about until as late as 11 o'clock, and that is very late in Panama, except for dances, and they last until daylight.

On Sunday night the Republican Band plays in the Plaza, and people of all races and a score of nations promenade. By consent of all, because it is an old custom,

Plaza the outside walk is used by the brown and Promenade. black people and the walk running east and west through the center of the plaza, by the whites. Of late years the inner walk is overcrowded by Americans, some of whom have the unfortunate attitude of appearing to want to push their hosts off the earth. Yet one sees a score of prominent Panamans in the plaza every Sunday night, and as many more girls and young women, the latter of ten lavishly dressed and distinctly pretty. The variety of Americans alone would make this promenade interesting, and one realizes by watching it how many generations away the American "type" must be. The excuse for the Sunday evening promenade and its opportunity to show and see pretty dresses, astonishing hats, and charming women, is the band concert. It is always good. The band practices constantly; it was organized by a high-grade musician, Santos Jorge, composer of the National Hymn of Panama, and is carried on under an able conductor.

The Bishop's palace is a square building, three stories high, built in 1880, and like the others constructed around a patio. Here the late Bishop lived a quiet Episcopal but busy life, and from this place the affairs Palace. of the oldest dioceses in America are administered. The palace contains, in addition to the Bishop's plain rooms, the offes and rooms of his assistants, and a boy's school.

In one corner of the Bishop's palace is the office of the Panama Jottery, almost as incongruous a combination as 
the old death trap tenements in New York Lottery. Gity owned by Trinity Church. Yet the lottery is a national institution, and although its effect is unquestionably bad on public morals, it has the overpowering prestige of custom. Gambling is prohibited in the constitution of Panama, but in the treaty of 1904 with the United States all vested rights under the Colombian Government were preserved under the new government. On this account the lottery will be allowed to run its legal life, which expires in 1918. Drawings are made every Sunday morning at 10 o'clock for prizes ranging in value from $\$ 3,500$ to $\$ 1.00$. Ten thousand tickets are issued each time. Most of the money that goes to make up the dividends of the lottery is paid by Canal workers.

Leaving the Plaza Independencia and continuing down Avenida Central, one passes on his right the French consulate, then the American legation (formerly Government a residence of the French Director General Building and and part of the purchase of 1904), and two

Theater blocks from the plaza, comes upon the Panama Government Building. This is a masonry edifice in four rectangular sections surrounding an inner court. It is 180 feet long and 150 feet wide. In the south section is the meeting place of the National Assembly together with offices, in the north the National Theatre, and in the east and west wings, Government offices. The construction was begun in 1905 and finished in 1908, the material being rubble masonry with cement plaster, and the style a modified Italian renaissance of the middle period. It is said to be fire-proof. The theater is a handsome one capable of seating a thousand people. It is built with a pit, a mezzanine floor, a tier of boxes, and a gallery. A metal curtain guards the opening between the stage and the amphitheater. Electric lights controlled by a stage switch are the means of illumination. The design, masonry, and the paintings in the foyer and on the ceiling are all by native Panamans. Here are held such public meetings of a nonpolitical nature as the Government sees fit to permit; and it is very generous in allowing all kinds of entertainments by Americans to be held here. Once a year a Spanish opera company and a Spanish comedy company make one or two week stands in Panama, and then there is a good crowd every night to hear and see. Popular operas, such as Lucia, Aida, Rigoletto, and more modern ones, 
such as the Merry Widow, are sung. The comedy company plays largely the works of Spanish dramatists. But the best part is between the acts when one leaves the warm amphitheater and goes out upon the balcony that overlooks the sea, gets the refreshing breeze, sees the stars, and smokes a cigarette.

The theater wing of the building is on the northwest corner of Plaza Bolivar, formerly Plaza San Francisco, a little park with tile walks, stiff benches, and a num-

Plaza ber of trees, among them the royal poinciana.

Bolivar. On the east side are the church of San Francisco and the walls of its ruined cloister; and diagonally across from this the oldest church in the city, San Felipe Neri (see pages 167 and 168).

Returning to Avenida Central and walking along the waterfront, one passes a concrete block building erected in 1908, the Methodist Episcopal Church and

Sea Wall, parsonage, and the home of a missionary Las Bóvedas. school called Panama College. A few hundred yards farther along the sea front, is the south bastion of the city, the fort that commands the approach by sea. This is commonly called The Sea Wall, or Las Bovedas (the arches or vaults) from the arch construction underneath in which are the dungeons formerly used as a prison. In these vaults, damp and filthy, thousands of criminals, political offenders, and mere suspects, spent days of slow death, poisoned by filth, and weakened by want of good food.

The dungeons have been abandoned, and here is now the Chiriqui Prison, a clean and well provided jail. The large building looking out upon the courtyard is the cuartel or barracks, in which the garrison formerly lived, since 1903 a part of the prison. The triangular space on the north side of the courtyard is known as the Plaza d'Armes, here the garrison used to be mustered, and against the wall, near the steps leading down to the water's edge, prisoners stood to receive the bullets of the execution squad. Inside the courtyard in front of the dungeons, so that the prisoners could see, there were held some years ago the bull teasings of the fiesta times, such as were held at an earlier date in Santa Ana Plaza. All these things one can see from the Sea Wall where the children roll about on their skates, and the boys and girls of various ages stroll or sit from sunset until late at night. The bright light on the water and concrete MR 22928—11 


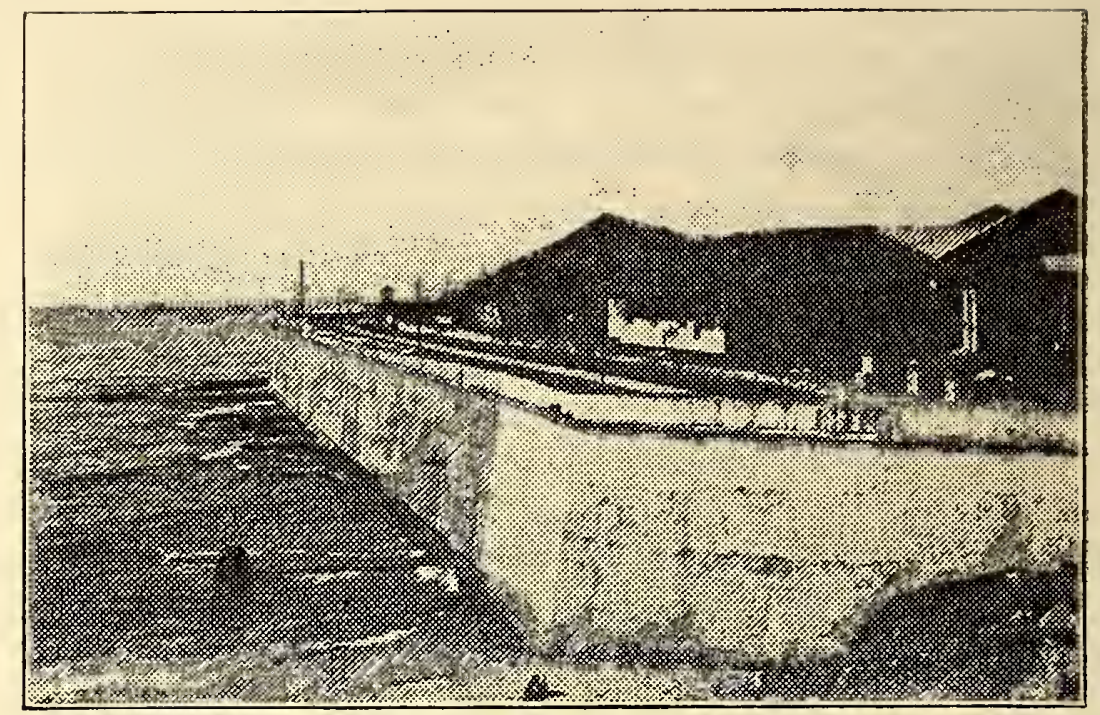

SEA WALL - LAS BOVEDAS-PANAMA.

walk, and the intense heat make this an unpleasant place during the afternocn, but about 5 o'clock, when the sun has dropped behind Ancon Hill, leaving the $u$ all in shadow and the islands still in bright light; or a few minutes later when the sunset glow is in the sky and on the water; or at night when all the stars are bright, then go to the Sea Wall and be quiet a few minutes while the spirit of Panama comes. up to woo you.

Right here in the heart of this place of romance, its front balcony locking cut upon the entrance to the Canal and the side of Ancon Hill, is the new home

University of the University Club. Here are served the Club. best meals in Panama, and here is the best collection of English books, and current periodicals. The building is 'of rubble and the style a modified Spanish mission. On the ground floor are the men's dining-rocm, game-rocms, kitchen, and office; on the second floor the licrary and reading-rccm, and the women's dining-rocm. The library and reading-room has a polished: hardwood floor and when cleared of tables gives a dancing. space of 2,800 square feet. The club was organized in 1906. and its membership of 200 consists of about 125 Americans: employed on the Canal or railroad and 75 residents of Panama. It was started as a club to which only college or university graduates could be admitted, but inasmuch as this. rule barred the most desirable men it was soon amended. 
Keeping to the seafront and walking back again past the Government Palace, and the Plaza Bolivar, at a distance of two blocks from the latter, one comes Union Club. upen a large white building of rubble masonry, the home of the Union Club. This is the best club building on the isthmus, and from its roof one may obtain the best view of Panama Bay that can be had, barring only that from the top of Ancon Hill. A large ballroom, a pleasant patio, and a swimming tank, flled anew each time the tide comes in, are among the attractive features of this club.

The Marina building is on the waterfront, near the Union Club and at the foot of 5 th Street. It was formerly a hotel, now used variously for offices and Sea Gate. family quarters. But its true interest lies Marina Hotel. in the fact that here is the water gate of the city, where passengers for ports along the coast take their ships after a long row in an open boat. The experience of going aboard one of these ships is exciting and always more or less wetting.

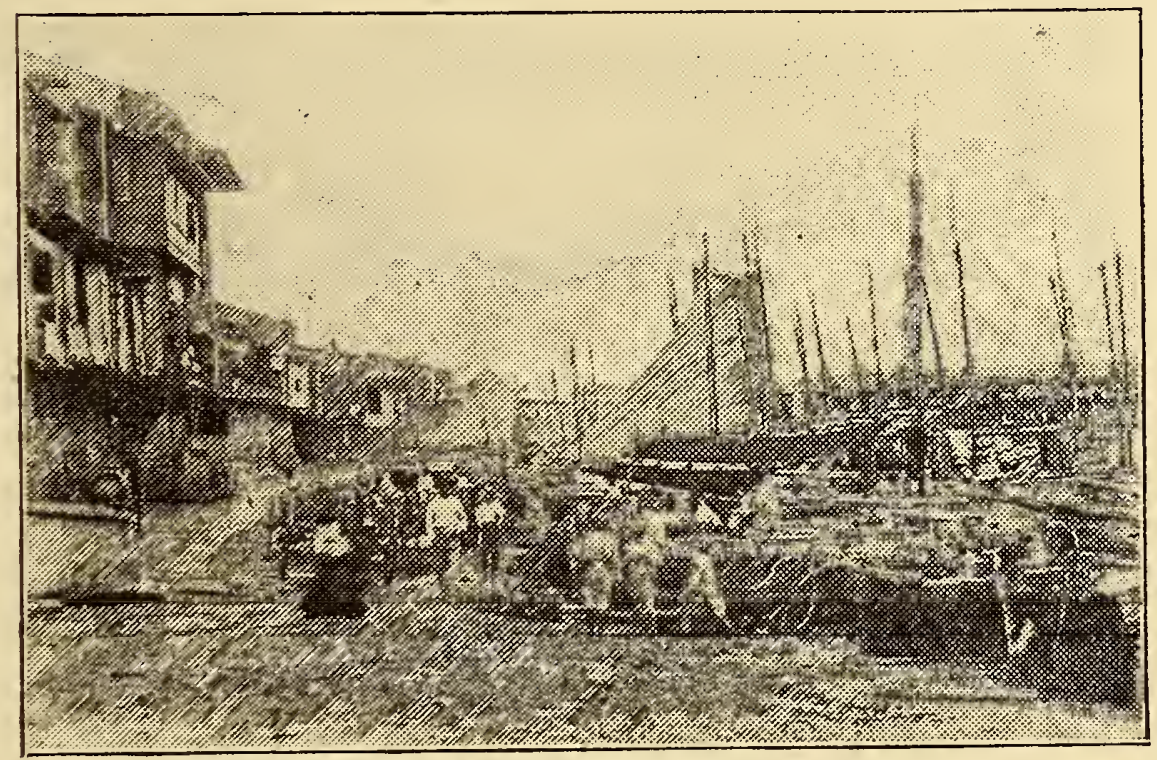

BEACH MARKET AT PANAMA.

Diagonally across the street from the Marina is the Presidencia, a rubble building, two stories high, built around a patio, a true example of Spanish mission Presidencia. architecture. Here lives the President, and here are the executive offices. On the walls 
of the public reception-room are pictures of the Presidents and Governors of Panama.

Still following the waterfront, two blocks beyond the Presidencia, the street dips down a steep incline, at the foot of which the old wall used to abut upon

Market. the sea. When the pretense of a walled city was dropped a breach was made at this point, and a road built, giving means of egress from the town to the beach. Here (1877) was established the market. It is now a large open building in which all sorts of merchandise are displayed-laces, vegetables, meats, fish, fruits-a great array of familiar and strange looking things. On the beach the ships from along the coast and the boats from nearby places unload, running in at high tide and waiting until the tide runs out when they can unload upon the beach without the expense and trouble of lightering. About 7 o'clock in the morning is the best time to visit the market, because then one sees how the purchases are made, a little of this and less of that, just enough for the day's needs. This is the most picturesque place in Panama from the point of view of those who are interested in people, for here all the races, and half the nations meet.

\section{The Churches.}

All the churches of Panama, from the cathedral in the city to the village churches of the interior, are built on the common plan of a long plain building with an ornate front.

The masonry is a rubble laid in cement, the class being called mamposteria. In this method of building the masons erect wooden forms as they would for concrete molds, and in these lay rock and brick of all kinds with cement joints. When the wall thus made is completed there is applied a plaster of cement and usually this is painted. The plaster gives a finished effect, and likewise keeps the soft rock from decomposing. In the churches the facade is sometimes made of dimension stone, smooth dressed. All of the more substantial buildings are erected in this manner, and they are good buildings, as 200 years of wear attest. The old walls are also of this class of masonry. Stone is procured from the fields or the beach at low tide, and the older churches in Panama were built of rock taken from the old city.

The architecture is that type of Moorish modified in Spain by the Christians of the 15 th and 16 th centuries, and still further modified in the new world, according as local 
conditions demanded. It consists essentially of two towers, between which is built the front wall with the main entrance surmounted by windows or by niches for statues. Sometimes one of the towers only is carried above the level of the roof and again there will be no distinct tower, but only a steeple rising from the main building. Always, however, the effect is the same. They have also in common paved floors, for there are nocellars under the buildings of Panama, and wood altars carved, or painted in imitation of marble or other stone. There are no decorations except those on the altar, and usually these seem gaudy to the American. In short the buildings themselves are plain and strong, with decorative fronts, the whole making a handsome apearance, but the interior decorations are not in keeping.

For the quality of such decoration as there is one must simply admit that tastes differ. The clothing of the Virgin in some churches is gaudy, in others tawdry, in some few ordinary French dolls are made to do duty as statues. The lack of value in the altar decorations is due to vandalism and sacrifice. At the time Spain made her effort to regain Quito by way of Panama, the available funds of the churches in the city were taken by Murgeon to help pay for transporting his army. It was in the nature of a loan, but it was a dead loss. In the revolutionary movement that freed the is thmus from Spain, the church provided the revolutionary government liberally from what treasure it had left. In the Liberal revolutions between 1850 and 1900 , when friends of the church were not in power, much of the available gold and silver in the churches was confiscated by legal and illegal means. Add to these facts and to the devastating fires, the great fact that from 1750 to 1850 , Panama was very poor, and you have the reasons why the churches of the city are not rich in altar decorations, as one would expect the churches of a Latin community to be.

One other thing they have in common that will be new to the untraveled tourist, and that is the custom of placing memorial tablets in the floor and on the pillars that support the roof. These tablets usually cover a bone from the peron of the dead to whom the tablet is dedicated, the custom being to bury the dead hut later to take one of the bones and place it in the church, in some instances the whole body of a distinguished person. An interesting indication of the cosmopolitan nature of the isthmian population for a century or more is found in many of these tablets 
Here one sees the names of Spanish, French, Irish, English, and Germans mixed, as though one would read-To the sacred memory of Isabella Davila de la Guzman, beloved wife of Thomas O'Hara Lopez.

Permit your guide to say that in the ardor of sightseeing many strangers (not of your kind, of course, yet well dressed people) seem to forget that

These are to the Roman Catholic his church is a holy Holy Places. place, for in it there is always in bodily presence Jesus Christ. You will see the children playing about the doors, perhaps, but it is not in irreverence; it is their Father's house, and they are familiar without being disrespectful. Yet when a stranger enters with his hat on, and walks about as he would in a hotel, the people resent it. They are his host and the feelings of the host should be respected. Much of the hatred of Latin Americans for Americans is due to the bad manners of the latter.

Although it was the first church in the new city to be located, the cathedral was one of the last to be completed.

The work dragged on for many years until

Cathedral. 1751 when Luna Victoria became Bishop of

Panama. This man was a negro, the son of a freed slave who had made some money for himself in the business of burning charcoal along the banks of the Rio Grande. The charcoal burner gave his son the chance for an education, and the son developed so well that he was taken into the priesthood. There he distinguished himself as a student and by his rectitude. He was the first native Panaman to become bishop of the diocese. Although he remained here only eight years, he plied the work on the cathedral with such zeal, and contributed so liberally to the fund for building, that it was completed on December 3, 1760 . It was consecrated on April 4, 1796, by Bishop Gonzales de Acuna, to whose liberality it owes the high altar and many ornaments of the sanctuary.

The cathedral is a basilica of one main and four side naves. Two Moorish towers with high steeples rise up from either side in front, and recessed back from the line of the towers is the facade of dressed stone with niches for statues of the twelve apostles. There are three doors in front, and two at the sides; the aisles from the frontand side entrances cut the church up into four quadrangles. The church proper is about 200 feet long. Essentially it con- 
sists of four walls of rubble masonry within which are four rows of masonry pillars connected by arches upon which rests a roof of finished native cedar. Outside, the roof is covered with pantile. The arches of the main nave span a space 36 feet wide, and spring from their columns at a height of 30 feet above the floor, the crown of the arch being 50 feet above the floor. The arches of the side naves span a space 21. feet wide, and those over the small naves, between the side walls and the secondary naves, a space 15 feet wide. The apse is formed by two arches, 40 feet to crown, supported on two rows of pillars. Within it is the high altar, made of wood and very ornate, two side altars, and the episcopal throne. Outside of the apse, but within the sanctuary, are two large side altars. Two more side altars are outside the sanctuary. A moulded and begrimed painting, said to represent the miracle of the Rosary, is pointed out as a Murillo. There is no documentary evidence to establish the authorship. In the earthquake of 1882 part of the facade was jarred out and fell upon the steps. This was at once repaired, and in accordance with the original plan.

On the east side of the Plaza Bolivar is the church of San Francisco, and adjoining it the ruins of the old Franciscan convent, burned in the great fire of 1756 .

Church of Upon the foundation of the new city the site San Francis- for the Franciscan monastery was alloted, co and Ruins and the plaza now called Bolivar was named of Convent. San Francisco after the church and convent. The church was burned also in 1756 , but it was rebuilt in 1785-1790, in its present form. It is 90 feet wide across the front and extends from the plaza to the sea, a distance of about 180 feet.

It is a basilica with nave, two aisles, transept, and apse. The nave is built of ten 6-foot-square masonry pillars in parallel rows of five each. Supporting arches which spring from them at 20 feet above the floor, are 25 feet above the floor at the center, and span a 35-foot opening. The choir over the entrance is supported by a flat arch. The side aisles are 20 feet wide and the choir above them is supported on groined arches. The transept is formed by two big arches 45 feet above the floor at the center, 25 feet above at the spring, and spanning a space 35 feet wide. Back of the transept, in the center, is a shallow apse in which the high altar is built. It is of wood, painted to imitate marble, and is surmounted by the all-seeing eye in a triangle that Americanc. 
are accustomed to associate with Freemasc nry. There are two side altars, built out into the transept, and not occupying apses. Along the side aisles are shrines, built up of wood and resembling altars, but not actually used as such. On the left of the entrance is one of these shrines containing a remarkable picture of some merit, although the light does not permit its being seen to full advantage. The subject is one that will immediately arrest the eye of a Roman Catholic because it is such a naive and compact representation of the doctrine of purgatory. The upper half of the picture represents heaven, where are some well-contented-looking people, while the lower half shows a number of people upon whose faces are written much pain, despondency, horror, fear. Through an opening in the cloud-made floor of heaven, angels are coming down to those in torture, carrying them indulgences in the shape of scapular's, rosaries, and other prayers. Some of the occupants of this pictured purgatory are in a large cage upon the top of which, in a region supposedly typifying earth, can be distinguished a priest with acolyte celebrating mass. The democracy of the artist, so of ten commented upon, is here shown by the people he has placed in purgatory. There are a king, a bishop, a priest, and ten lay members; and out of the thirteen thus condemned only three are women. Of the ten people shown in heaven three are women, but all the angels look like girls. Knowing the real proportion of females to males on earth, one can gain a pretty fair idea of where the artist thought the majority of women belong.

The ruin of the old convent contains the most beautiful cloister or row of arches to be found in the city. It extends along the street 255 feet and reaches back to the sea 180 feet. The building was two stories high. The windows have been filled with various kinds of masonry, and against the walls inside have been erected wooden buildings used now as schools. The old courtyard has been divided into two parts, one being used by the Christian Brothers in their Collegio de la Salle, and the other by the Government in its school of San Felipe for boys.

The church of San Felipe Neri at the corner of Avenue $B$ and 4 th Streets is the oldest in the city. In a cement tablet above its entrance are the words "Neri

San Felipe Ao 1688." It is said that it was constructed

Neri. entirely of rock brought from the old city of Panama. Formerly there was a little yard 
in front and the church had an outlook on Plaza Bolivar, but within recent years a house has been built in the yard closing the front door, and necessitating the opening of an entrance on Avenue B. The door has been closed only so far as the public is concerned, however, because it is still the opening by whi' $h$ the Sisters of Charity and their pupils enter the old church. The fire of 1756 , which swept over all that part of the city, burned the woodwork out of the church and it was not until 1800 that it was reconstructed in its present form.

The building is about 100 feet long and 60 feet wide, and is constructed of rubble masonry with heavy walls which bear directly the thrust of the gable roof, there being no supporting columns within. A little Moorish tower decorated with mother of pearl shells rises up from the gospel side of the front, and is balanced on the other side by a tiny turret. Between these the roof points up, and in the center is an oval window bordered with pearl shell. Above the side entrance, the one in public use, is a little wooden statue of San Felipe bearing a chalice in one hand and a child on the other arm. The worms have eaten the statue away as to its nether parts but it still remains a good piece of wood carving.

Within the walls is the prettiest church in Panama, the only one that shows good taste in adornment. The chancel is at the end opposite the door, and extends from the floor to the gabled roof, whereas the balance of the interior is covered by a board ceiling, as though to make a choir or second floor where worshippers may be unobserved by the public below. The result is that, while the seating part of the church is in a soothing gloom, the altar stands out brightly, making a pretty contrast. On both sides the heavy walls are built in several feet so as to make large masonry niches in which are two shrines or side altars. There is a calm, soothing atmosphere about this church that is quite lacking in the others. Leaving it through the old entrance (strangers are forbidden to do this), one enters a courtyard around which are the houses of the sisterhood. A little garden fills the yard, some trees grow there, and butterflies and birds fly about the triees and tushes. It is cut off from the street by the houses, the church, and a high wall. And it is very quiet.

The church of Our Lady of Mercy (La Merced) is on Avenida Central at the corner of Tenth Street. It is the second 
oldest church in the city, and was constructed La Merced. partly of stone from old Panama. Near it ran the old wall and a few feet away was the drawbridge. Two Moorish towers rise up from either side of the facade, which, like that of the cathedral, is made of dimension stone. Above the door is a niche for the statue of Our Lady of Mercy. The church is 80 feet wide, and 120 feet long on the Central Avenue side. Within, two rows of four wooden pillars each covered with decorated sheet iron of the year 1890 support the roof and give the effect of a central and two side naves. At the rear an arch, spanning a space 40 feet across, springs from the sides at 30 feet above the floor, and is $\mathbf{5 0}$ feet high at the crown. This forms the chancel in which is situated the high altar. Outside this imitation apse are two side altars, while along the left side wall are four shrines, and along the right three. In the right side there is also a large door opening upon a terrace that parallels Central Avenue. This church is a disappointment in every way-architecturally because it is an imitation, spiritually because the interior decorations are so tawdry as to be almost mirth-provoking. All the statues are very bad, and one of them, representing the Blessed Virgin, is a doll. Not a part of the building, and yet of the church, are two chapels built in front of the towers, one a mortuary chapel, and the other an ex-voto offering. This latter is near Central Avenue, and every evening there can be seen in it some of the faithful at their prayers.

The Ghurch of Santa Ana was originally a wooden structure built for the poorer classes in the suburb of Santa Ana which was inhabited largely by negro servants.

Santa Ana. About 1760 Mateo de Izaguirre e Ibarzabal furnished money for the reconstruction of the church in masonry, and it was dedicated on January 20, 1764. The Spanish crown conferred knighthood on the man who gave the money, and he was afterwards known as the Count of Santa Ana.

This building is of rubble covered with cement mortar, but with a front of dimension stone. A moorish tower rises from one side of the facade, but the other side is merely the end of the gable roof, which has been covered with the false wall done in scroll, characteristic of most of the church buildings in Panama. The dimensions are 70 feet long by 160 feet wide. A front and two side doors give entrance, and the aisles running from them cut the interior into four 
equal quadrangles. Parallel rows of wooder pillars and the side walls support the roof. The sanctuary is fcrmed by a large central masonry arch spanning a space 36 feet across, springing at 20 feet from the flocr and $\mathbf{4 0}$ feet above the floor at its crown, and two smaller arches with crown 25 feet above the floor. The center arch spans the high altar, and the side arches the altars of the Virgin and the Sacred Heart. Outside the sanctuary, on the Sacred Heart side, is an effigy in a glass case of the Count of Santa Ana. Glass eyes are turned skyward, and a heavy black mustache carefully brushed adorns a face so fair that it is quite pink. On the screen at the entrance to the church is a portrait in oil of the Count. Along the wall on the epistle side of the church are three shrines, one framing an interesting picture of the crucifixion, and on the gospel side are two shrines. The interior of this church is cold and cheerless, and what color there is seems very tawdry to one not accustomed to such things.

The church of San Jose stands at the corner of Avenue $A$ and 8 th street, and is the church of the Augustinian friars. It has a front of $\mathbf{4 0}$ feet on Avenue $A$, San José and is $\mathbf{8 0}$ feet deep along 8 th street. It has a gable roof, but inside is finished with a barrel arch nave 40 feet high, apparently supported on two rows of six wooden posts. The apse is framed by the three arches at the termination of the main and side naves, and a skylight above it allows the daylight to illuminate the chancel effectively. The altar is decorated in good taste, the five side shrines are modest, and the whole interior has an air of quiet.

The Dominican friars began to build their church and convent in new Panama immediately after the founding of the city. In Old Panama they had a sub-

Ruins of stantial building of stone, and some of this San Domingo entered into the edifice in the new city. In

Church. the fire of 1756 all the woodwork was burned, and the church was not rebuilt. It is a typical piece of the architecture of the period, the facade still showing where the towers rose, and the little statue of Saint Dominic still standing above the broad front entrance. The church is situated on the corner of Avenue $A$ and $3 d$ Street. It is built of rubble masonry, with dimension stone in the facade, and was erected by the lay brothers of the order. It is 75 feet wide and 120 feet long. The nave is 70 feet deep. Instead of having side naves the church has three arches or 
vaults for shrines on each side, and one arch on each side for entrances, that on the street side for the people and on the side opposite as a means of entrance from the courtyard of the old monastery. The apse is 50 feet deep and is formed by three grand arches (one was shattered in the earthquake of 1882) and two side arches. Near the main entrance, forming one of the supports for the choir, is a brick arch, spanning a space of 50 feet, 35 feet high at the crown and 25 feet at the spring. So flat an arch is said to be an engineering "sport," and it is pointed out as one of the sights of the city. Arches almost as flat will be found under the choir of the church of San Francisco, and in the ruins of the old Jesuit church. Alongside the ruins is a chapel of modern construction and still in use. The old church is now private property and a modern apartment house is now projected for the site.

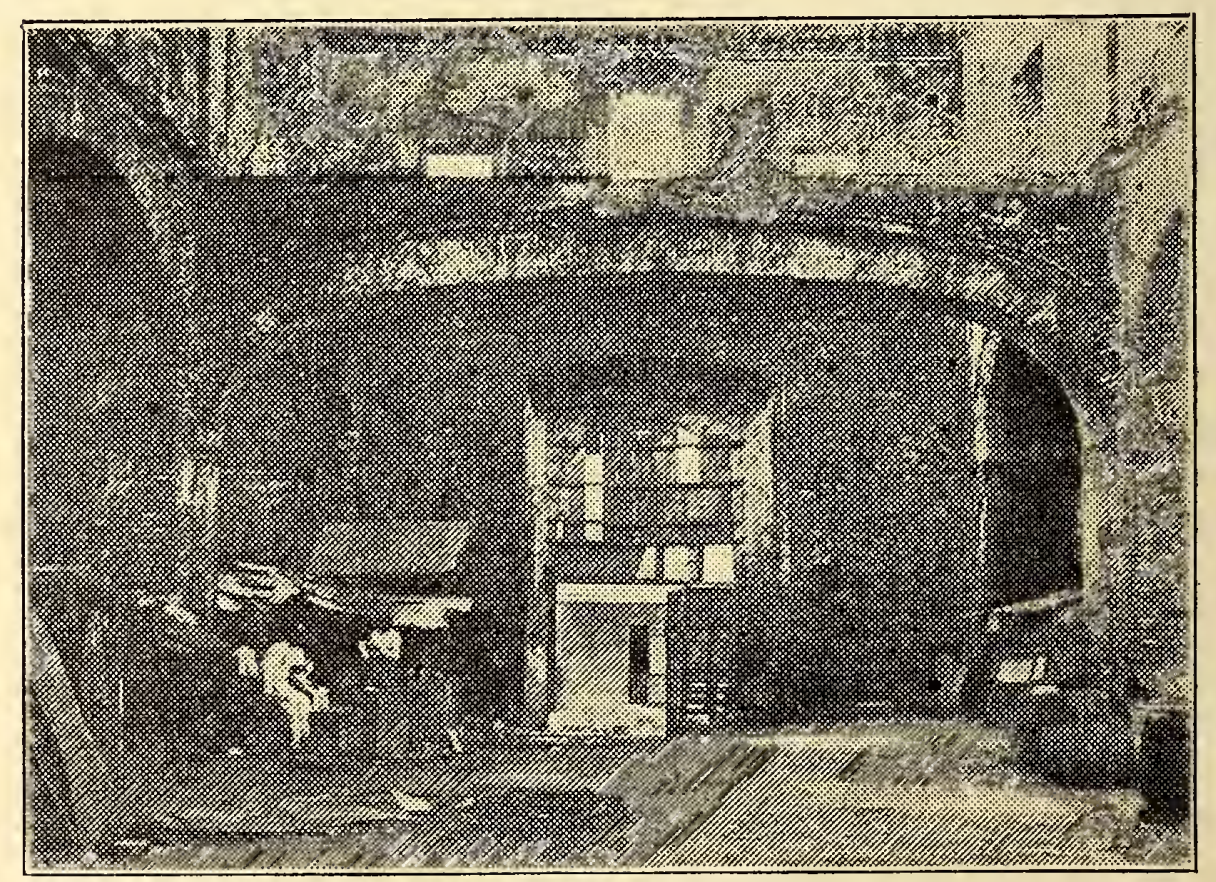

FLAT ARCH IN CHURCH OF SANTO DOMINGO-PANAMA.

In the first years of the decline in Panama, before it was fully realized just what the abandonment of the trade route across the isthmus meant, the Society Ruins of Jesuit of Jesus began to build a college and convent Church and in Panama. The first work was done in 1749 Convent. and the building was completed in 1751. It consisted of a church on the corner of the pres- 
ent Avenue $A$ and 7 th Street (extending back along 7 th street to the edge of Cathedral Plaza), and a long rectangular building joined to the church, which was to serve as dormitories and school for the students of the University of the Holy Savior. The political activity of the order in Latin Europe about this time led to the movement for its suppression in Spain, France, and Portugal, and the decree of 1767 driving the Jesuits out of Spain was made effective in Spanish America. On August 28,1767, the priests of the University of San Javier in Panama were put upon ship at Porto Bello and sent to Europe, and thus within 20 years after the opening of their university, the magnificient building was vacant. In 1781 the fire that burned out all that section of the city consumed every bit of wood in the Jesuit church and college. The property was confiscated by the State during one of the Liberal governments of the Colombian period, and was purchased by a Panaman family. In 1909 the walls were still standing gaunt and empty, when a cheap wooden frame was built up inside of them and the old college was turned into a tenement house. But the church is still much as it was after the fire, except that some sheds have been built within it, and horses and cows are stabled in the sanctuary of the apse. Notwithstanding the vandalism, the ruin is one of the most interesting to be found on the isthmus. Apropos of the ban on the Jesuits, it is of interest that the late Javier Jungito, Bishop of Panama, was of the Society of Jesus.

\section{Newspapers.}

The first newspaper published in Panama was a revolutionary sheet issued in March, 1820. A newspaper in English-The Panama Star and Herald-was first

Newspapers. published in February, 1849. It was printed then, as now, half in English and half in Spanish, and during the French period there was a section in French. In 1911, The Panama Journal, a daily in English, began to issue. There are several periodicals in Spanish, each representing the fortunes of some editor-for-politics only. The Canal Record, published in Ancon, is the official bulletin of the Isthmian Canal Commission. It was first issued on September 4, 1907.

\section{National Institute.}

On the borderline between the Canal Zone and Panama city, with its broad bare back facing towards Ancon, is the new home of the Panama National Institute, 
Nationa! opened in 1911. It consists of seven buildInstitute. ings of rubble masonry, Spanish mission type, surrounding a large courtyard, in the center of which is a gymnasium. This is the largest building in the Republic. It is planned to make it the head of Panama's educational system, but at present the pupils are mostly children in primary and secondary work. No tuition is charged, and nonresidents of Panama are supplied with room and board while in attendance at the school. (See page 140.)

\section{Amusements.}

The amusements of a formal kind offered by Panama are few. Twice a year there are traveling troupes at the National Theater; twice a year a circus pitches

Amusements. its tents for a week's stay in Herrera Plaza; every Sunday there is a cock fight in the main back of the old drawbridge bastion; and every night there are moving-picture shows along Central Avenue. A favorite drive is that out the Sabanas Road toward Old Panama, or starting in that direction making a detour toward Corozal. Every year before Ash Wednesday there is a carnival in which the people elect a queen, and around her and the God Momus, make a play at the old game of sovereign and people. Then there are parades, masked balls, and a coronation ceremony in the National Theater. Native dances are done in the plazas, and four days are given over to masking, serenading, and dancing. About a mile beyond the city, well removed from the outfall of the sewers, there is a crescent-shapedbeach where one may go sea bathing. The dressing rooms are poor, however, and the place is difficult of access. The best day's trip for a tourist to take is the ride across the bay to the island of Taboga. A steamer makes this trip daily.

\section{Coach Tariff.}

Coach Rates

The fare for a single ride for one person

Panama and in Panama city is ten cents, United States Vicinity. currency, represented by a Panaman coin commonly known as "twenty cents silver."

The coach tarriff follows:

$$
\text { Hourly Rates. }
$$

Between 6 a. m. and 11 p. m.,

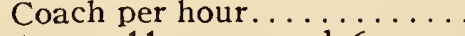

Between 11 p. m. and 6 a. m. Coach per hour. .

\begin{tabular}{cccc} 
& \multicolumn{2}{c}{ PERsons. } & \\
One. & Two. & Three. & Four. \\
1.00 & 1.25 & 1.50 & 1.75 \\
1.25 & 1.50 & 1.75 & 2.00
\end{tabular}


Ancon and City of Panama.

Between the Episcopal chapei (hospital grounds) and any. point in Panama, or any point in Ancon east of Episcopal chapel................

Between Hotel Tivoli or its environs and any point in Ancon east of Episcopal chapel. . . . . .

Between any point in Ancon on the Zone line road as far south as House No. 115, and any other point in Ancon east of Episcopal chapel, or any point in Panama..............

Between kitchen building of Ancon Hospital and any point in the hospital grounds.......

Between kitchen building of Ancon Hospital and any other point in Ancon east of Episcopal chapel, or any point in

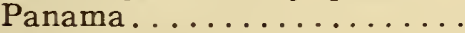

Between Administration building in Ancon and any point in Ancon north of postoffice or any point in Panama.........

Between the fire station in Ancon Hospital grounds and any point in Ancon east of Episcopal chapel..............

Between Ancon Hospital cemetery and any point in Ancon east of Episcopal chapel......

Between any points in Ancon embraced in the boundary enclosed by street running from Administration building to Roman Catholic chapel thence to postoffice; thence souihwesterly on Zone line road; thence to Administration building .................

Between any point in Ancon east of Episcopal chapel and any other point in Ancon or any point in Panama .........

Between intersection of Bishop's Hollow and Ancon Hospital roads (east of new corral) and any point in Panama or Hotel Tivoli and its environs or any point in Ancon easi of Episcopal chapel...............

Between Ancon Insane Asylum (Bishop's Hollow road) and any point in Panama or Hotel Tivoli and its environs or any other point in Ancon east of Episcopal chapel...........

Between I. C. C. labor camps (Bishop's Hollow road) and any point in Panama or Hotel Tivoli and its environs, or any point in Ancon east of Episcopal chapel................

Between any point in Ancon east of Episcopal chapel or any point in Panama, and the old ice factory (out Sabanas road) ..................
PERSONS.

One. Two. Three. Four.

$\begin{array}{lrrrr}\text { One way... } & .10 & .20 & .30 & .40 \\ \text { Round trip } & .20 & .40 & .60 & .80 \\ & & & & \\ \text { One way... } & .10 & .20 & .30 & .40 \\ \text { Round trip } & .20 & .40 & .60 & .80\end{array}$

$\begin{array}{lllll}\text { One way... } & .10 & .20 & .30 & .40\end{array}$

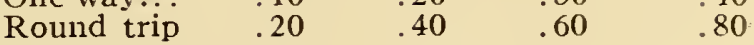

$\begin{array}{lllll}\text { One way... } & .10 & .20 & .30 & .40\end{array}$

$\begin{array}{lllll}\text { Round trip } & .20 & .40 & .60 & .80\end{array}$

$\begin{array}{lllll}\text { One way... } & .25 & .50 & .60 & .70 \\ \text { Round trip } & 50 & .75 & .90 & 1.00\end{array}$

$\begin{array}{lllll}\text { One way... } & .20 & .40 & .55 & .65\end{array}$

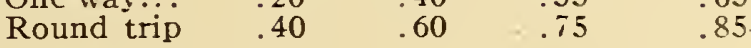

$\begin{array}{lllll}\text { One way... } & .35 & .70 & 1.00 & 1.25\end{array}$

$\begin{array}{lllll}\text { Round trip } & .70 & .95 & 1.20 & 1.40\end{array}$

$\begin{array}{lllll}\text { One way... } & .50 & .75 & 1.60 & 1.25\end{array}$

$\begin{array}{lllll}\text { Round trip } & .75 & 1.00 & 1.25 & 1.50\end{array}$

$\begin{array}{lllll}\text { One way... } & .10 & .20 & .30 & .40\end{array}$

$\begin{array}{llll}\text { Round trip } & .20 & .40 & .60\end{array}$

One way... $\quad .10 \quad .20 \quad .30 \quad .40$

$\begin{array}{llll}\text { Round trip } & .20 & .40 & .60\end{array}$

$\begin{array}{lllll}\text { One way... } & .20 & .40 & .55 & .65\end{array}$

$\begin{array}{lllll}\text { Round trip } & .40 & .60 & .70 & .65\end{array}$

$\begin{array}{lrrrr}\text { One way... } & .30 & .60 & .75 & .90 \\ \text { Round trip } & .60 & .90 & 1.10 & 1.25\end{array}$

$\begin{array}{lllll}\text { One way... } & .35 & .70 & 1.00 & 1.25\end{array}$

$\begin{array}{lllll}\text { Round trip } & .70 & .95 & 1.20 & 1.40\end{array}$

$\begin{array}{lllll}\text { One way... } & .20 & .30 & .40 & .50\end{array}$ 


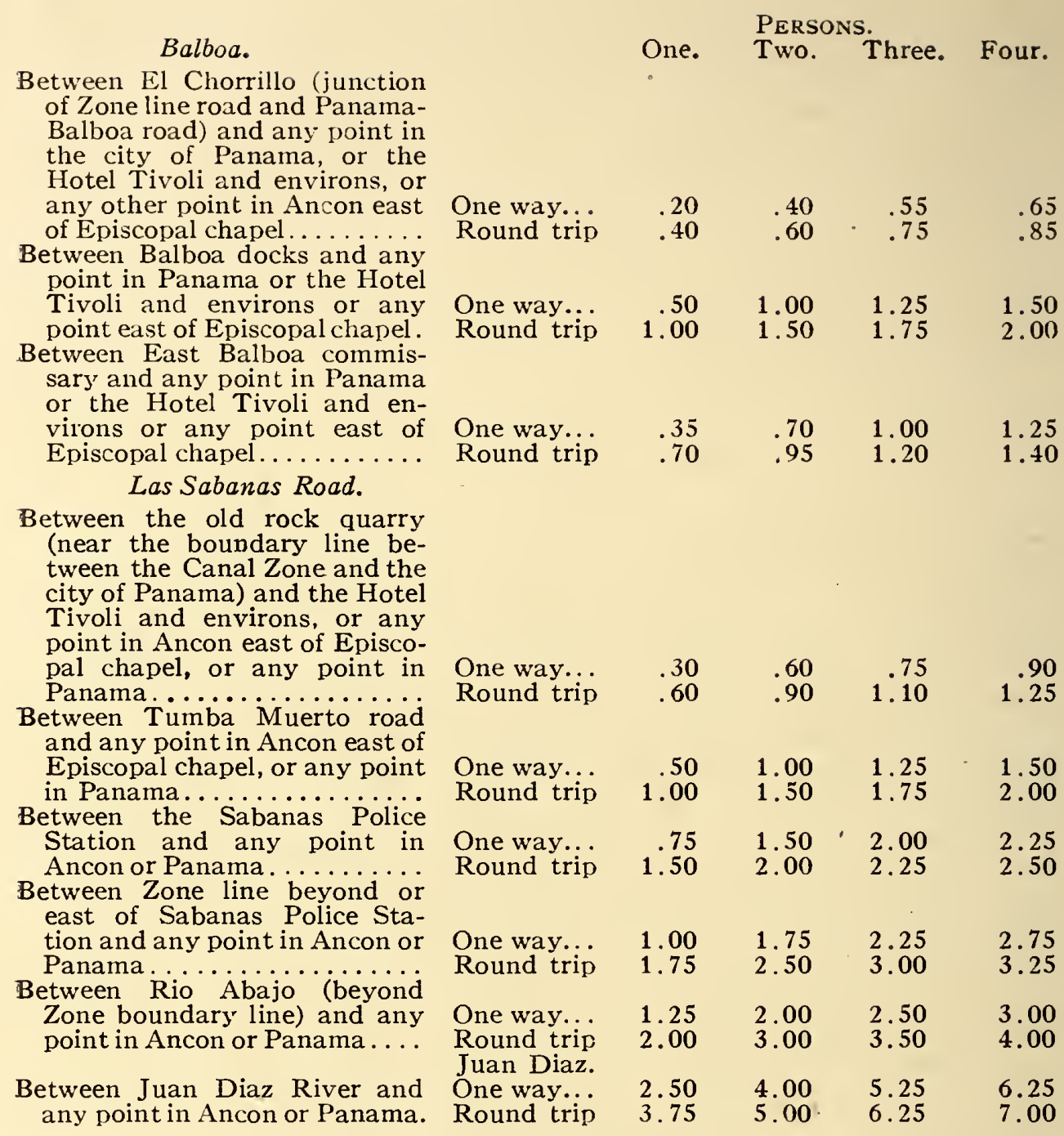

\section{Shoppers' Guide.}

The American shopper will find that all woolens, silks of foreign make, linens, laces, and lingerie, are cheaper in Panama than in the United States. Every Shoppers' shop has some curious bit of lace or other Guide. fabric to show, such as one is not likely to find in the United States. The Chinese shops show many curious bits of china, silk, Ganton linen, and brass. The residents of the city can buy goods much cheaper than visitors can, because they know the method of shopping, which is to bargain. This bargaining applies chiefly, however, to the Chinese shops, as several of the better class shops run by natives and by English and French citizens have adopted the one-price standard. Panama hats may be purchased at a dozen different stores. In the low grades there is little advantage in buying them in Panama, but in 


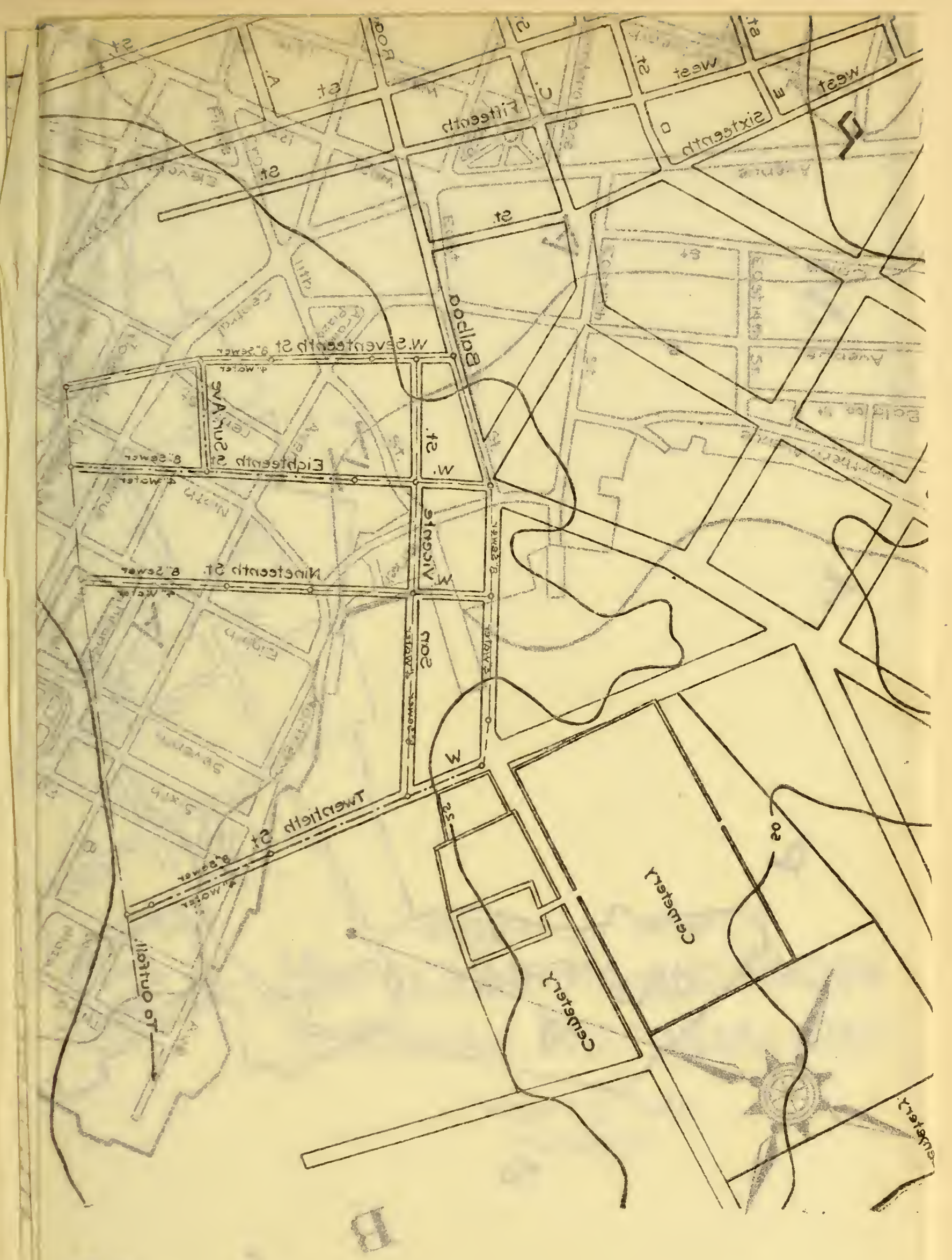



$=$ 

the hats that one pays from eight to fifteen dollars for the values are from fifty to two hundred per cent greater than at the same price in the United States. A shoppers' guide follows:

\begin{tabular}{|c|c|}
\hline $\begin{array}{l}\text { Automobules. } \\
\text { Morrice's Garage } \quad \text { Cathedral Plaza }\end{array}$ & \\
\hline Pan-American Automobi.e & \\
\hline $\begin{array}{c}\text { Co. } \\
\text { Bakeries. }\end{array}$ & 252 \\
\hline 225 Central Ave............................... & \\
\hline $\begin{array}{l}\text { East } 13 \text { th St....................... } \\
\text { Banks. }\end{array}$ & \\
\hline hrman \& $\mathrm{Co} \ldots \ldots \ldots$ & \\
\hline $\begin{array}{c}\text { nternational Banking Cor- } \\
\text { coration }\end{array}$ & \\
\hline $\begin{array}{l}\text { Panama Banking Co. } \\
\text { Buoks, Periodicals, Souvenirs. }\end{array}$ & \\
\hline 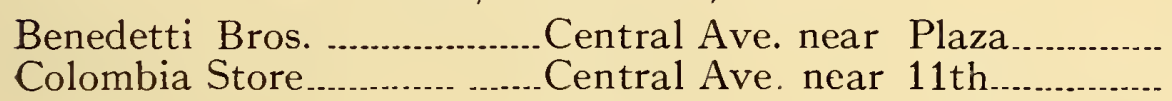 & \\
\hline 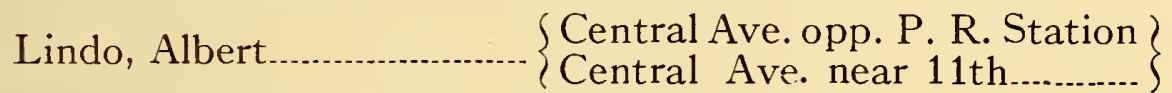 & 258 \\
\hline Maduro, I. L _ C Cathedral Plaza & \\
\hline Panama Guide............ & \\
\hline Vibert \& Dixon Central Avenue opp. Cathedral... & \\
\hline 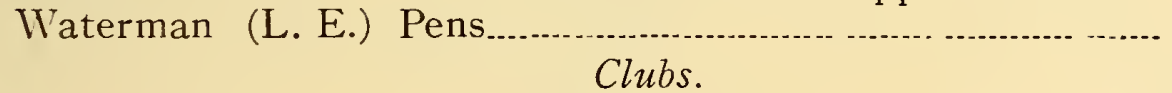 & \\
\hline International_......................... & \\
\hline Nor & \\
\hline ar Sea Wall.. & \\
\hline Corresponder & \\
\hline $\begin{array}{c}\text { International } \\
\text { Dentists. }\end{array}$ & 263 \\
\hline 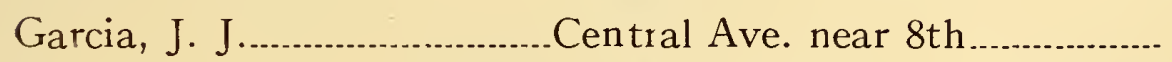 & 240 \\
\hline Drugs, Perfumes, etc. & \\
\hline Central Drug Store... & \\
\hline 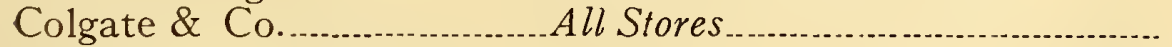 & 208 \\
\hline International Pharmacy & 211 \\
\hline DryGoods, Notions & \\
\hline B. V. D. Company & 296 \\
\hline French Bazaar. & \\
\hline La Carac & \\
\hline La Ultima Moda & \\
\hline Müller Co............................ & 302 \\
\hline 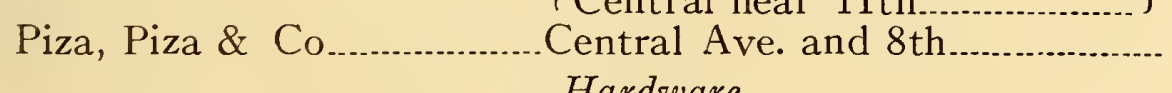 & 210 \\
\hline Lyons, Emanuel............... & \\
\hline 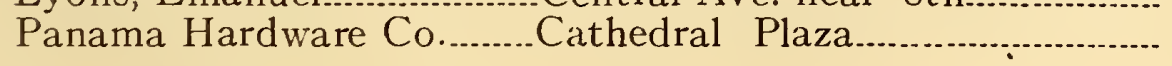 & 234 \\
\hline
\end{tabular}




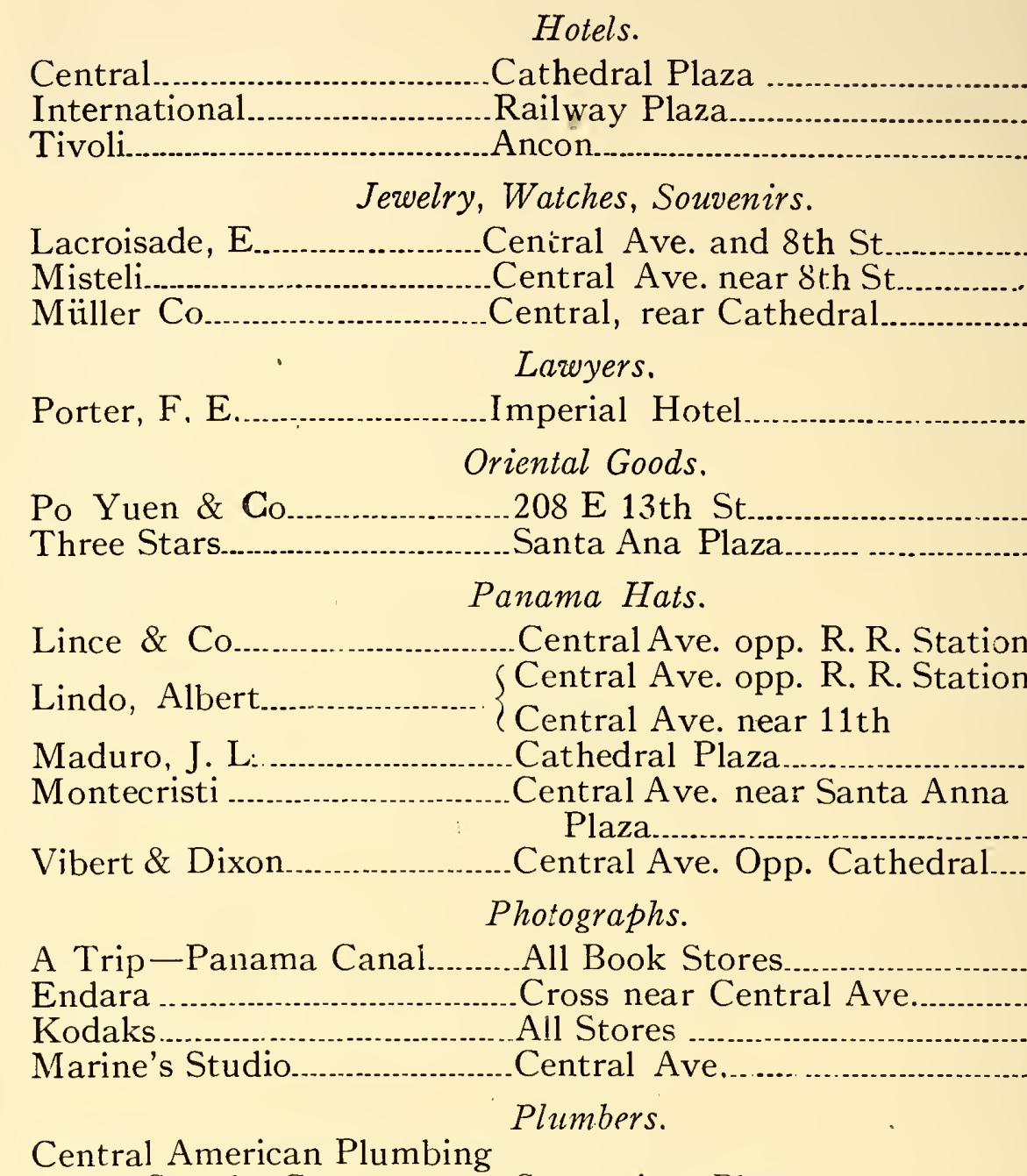

Sewing Machines.

Singer Sewing Machine Co....8th St., rear Cathedral

Steamship Companies.

California-Atlantic..................Balboa

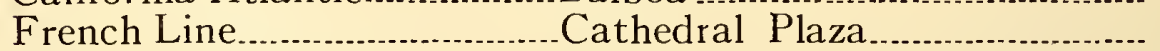

Hamburg-American...............5th St., near Cathedral Plaza....

National Navigation ................... North Ave. and 7th....................

Pacific Mail

Balboa.

Pacific Steam Navigation.

Panama R. R

Cathedral Plaza........................

Peruvian Line.

Railroad Station.

Royal Mail 11th near Central Ave

United Fruit Co Cathedral Plaza. 


\section{Old Panama.}

During 1911, the Government of Panama built a road to Old Panama from the highway that runs eastward from the present city through the rolling country that skirts the bay, known as Las Sabanas (the plains). It is possible, therefore, for the tourist to visit the site of the old city in a coach, or automobile. Soon the street cars will be running there.

The weeds have been cut down and paths lead to the points of interest - the old bridges across the estuary that bounded the city on two sides, the tower and church of St. Anastasius, the wells, and the foundations and walls of public buildings. But there are two other ways of reaching the site.

One is by sea in a launch, and its chief disadvantage is that the landing is made through the surf, and one is sure to be wet. It is more interesting, however, than the coach method; because one can imagine the old traders approaching the water-gate in this way; and there was a water-gate, for the hole in the wall is still the easiest method of entering the enclosure on the sea side, and you can see the old paved road leading into the water. But the best way of all is by horseback.

Start about 6 o'clock in the morning, and while the sun is yet low you will have left the highway, and be going across: the sabanas toward the old city. You can skirt

Go by Horse- the hills that lie in your path and save half back. an hour's time. It is time ill-saved, however, because from the top of the highest of these little eminences, you get a view of hill, plain, and sea, the sun rising over the new city, and touching the lone tower of the old.

The horseback route is the one by which the pirates approached Panama. It leads along a trail right up to the old bridge. If the tide is low it is better to leave this trail in the open plain where the hills are, and pick your way along the beach. Your horse knows how. It adds variety to the expedition, because you get a nearer view of the sea. 
From the point of view of being easily defended, the site of the old city was not bad. In front was a broad tidal flat over which only the lightest-draft boats could

The Site. come at low tide, and then could not get within a hundred yards of the walls, while at high tide ships could come up to the city gate, and when the tide went out, could be unloaded without the trouble of lightering. This method may be watched daily on the beach at the present city of Panama, where the market boatsdischarge. Behind was a broad sabana or open plain stretching away for a mile in some parts, and at every point open for hundreds of yards. No enemy could approach unnoticed across this space. A tidal estuary also ran around the site of the town providing a natural moat which could be easily defended. Two bridges crossing this moat gave access to the city, otherwise one must go through a swamp. Panama was captured five times, but never by surprise.

The plan of the city in 1609 , made by an Italian engineer, Roda, (see page 182) shows the lay-out of the town. Mr.W. Caley Johnston, of the Panama Government Map of the engineer service, at whose suggestion and unCity. der whose direction the old site was cleared, says that this map is very accurate, for al though the city was burned in $\mathbf{1 6 4 4}$, it was rebuilt on the old lines. There were two entrances one by the Royal Bridge, which was the beginning of the trail to the Atlantic, and one near the beach, at the west end of the city, which was the road to the slaughter houses. On the map I have indicated in a line of dashes the present entrance to the site, and it corresponds generally with the old main entrance. The locations of the chief buildings are accurate. The wall shown around the "casa real" was recommended but never built. 'The area shown by dotted lines was occupied by houses of wood and thatch. In fact, only the public buildings were of istone.

Among the local matters dictated by the Council for the Indies was the laying out of a city. It was provided that it be laid out from a central plaza as a reference point. On the east side of this plaza was set aside a large space of ground for the church, and alongside of it was built the house of the parish priest. On the west side of the plaza was erected the city hall or administration building. Four streets ran through the sides of the plaza, and along these, each in a prescribed place, were arranged the other buildings. 
On account of the heat the houses were built close together, to give shade to one another, and for the same reason narrow streets were insisted upon. How closely the rules thus laid down were followed in the case of Old Panama may be seen. from the map of the old city.

Practically all the buildings during the first hundred years were of wood, and this made it impossible to prevent the spread of fire in buildings set close together. In 1539, a fire destroyed a large part of the city; and in March, 1563, there occurred a fire that destroyed forty buildings. The first stone work to be attempted in the city was the cathedral, the foundations of which were laid in stone in 1577 .

Baptista Antonio writing in 1578, says:

"Panama is the principal citie of this dioces. It lieth 18 degrees from Nombre de Dios on the south sea, and standeth in 9 degrees. There are three monasteries in this said city of fryers, the one is Dominicks, the other is of Augustines, and the third is of S. Francis fryers; also there is a college of Jesuits, and the royall audience or chancery is kept in this citie. This citie hath three hundred and fiftie houses, all built of timber, and there are six hundred dwellers and eight hundred souldiers with the townsmen, and foure hundred negroes of Guyney."

\section{Of the city in 1610, Sosa and Arce say:}

"With a heterogenous population of 5000 souls, Panama possessed the convents of La Merced, St. Francis, St. Dominick, St. Augustine, that of the Jesuits, and of the monks Panama of the Conception; also the hospital of St. Sebastian in 1610. for the care of private persons, later in the hands of the brotherhood of St. John the Divine; and in process of construction for Catholic worship the Cathedral, dedicated to the Virgin of the Assumption, and two chapels, those of St. Anne. and St. Christopher. Panama had 500 houses of all kinds distributed among three plazas and eleven streets, making it beyond question one of the most important cities in Spanish America at this time."

Thomas Gage was in Panama in 1637, and Albert Edwards. quotes him as saying:-

"It is governed by a president and six judges and a court of chancery, and is a bishop's sea. It hath more strength towards the South Sea than any other port which on that side I hath seen, and some ordinances planted for defence of it; but the houses are of the least strength of any place that I had entered in; for lime and stone is hard to come by, and therefore for that reason, and for the great heat there, most of the houses are built of timber and bords; the President's house, nay the best church walls are but bords, which serve for stones and brick, and for tiles to cover the roof. It consisteth of some five thousand inhabitants, and maintaineth at least eight cloisters of nuns and friars." 
On February 21, 1644, a fire of incendiary origin destroyed 83 buildings, including the seminary and the bishop's house, and seriously demaged the cathedral. The

Fire of 1644. rebuilding of the cathedral was begun immediately, and the walls were made entirely of rubble masonry, the plan being that of a basilica with one main and two side naves, and in front a side tower that raised i ts cupola high above the surrounding buildings. This cathedral was dedicated in 1655 , and the records show that its high altar was richly adorned. It is probable that after this fire other buildings of a public nature were constructed of stone, because it is certain, both from the records and from the the ruins extant, that there were many masonry buildings in the city at the time it was taken by Morgan and his pirates.

In reading the following description by Esquemeling it must be remembered that he was comparing old Panama with the squalid cities of Europe and the West Panama Indies, with which he was acquainted; that in 1671. he was quoting the perfervid stories that had been told the pirates in order to urge them on their hazardous enterprise; that he had no opportunity to judge of these things himself, because the fire that destroyed the city was started immediately after the pirates entered; and, finally, that he was representing the place to be as large as possible in order to show how brave the pirates were, and likewise to reinforce his argument that Morgan had not distributed all the booty. Of the city in 1671 Esquemeling says:-

"All the houses of this city were built with cedar, very curious and magnificent, and richly adorned, especially with hangings and paintings, whereof part were before removed, and another great part were consumed by fire. There were in this city (which is the see of a bishop) eight monasteries, seven for men, and one for women; two stately churches, and one hospital. The churches and monasteries were all richly adorned with altar-pieces and paintings, much gold and silver, with other precious things, all of which the eccelsiastics had hidden. Besides which, here were two thousand houses of magnificent building, the greatest part inhabited by merchants vastly rich. For the rest of less quality, and tradesmen, this city contained five thousand more. Here. were also many stables for the horses and mules that carry the plate of the king of Spain, as well as private men, towards the North Sea. The neighboring fields are full of fertile plantations and pleasant gardens, affording delicious prospects to the inhabitants all the year. The Genoese had in this city a stately house for their trade of negroes."

It is evident that Old Panama was not a grand city from the viewpoint of today, but it was the most important place 


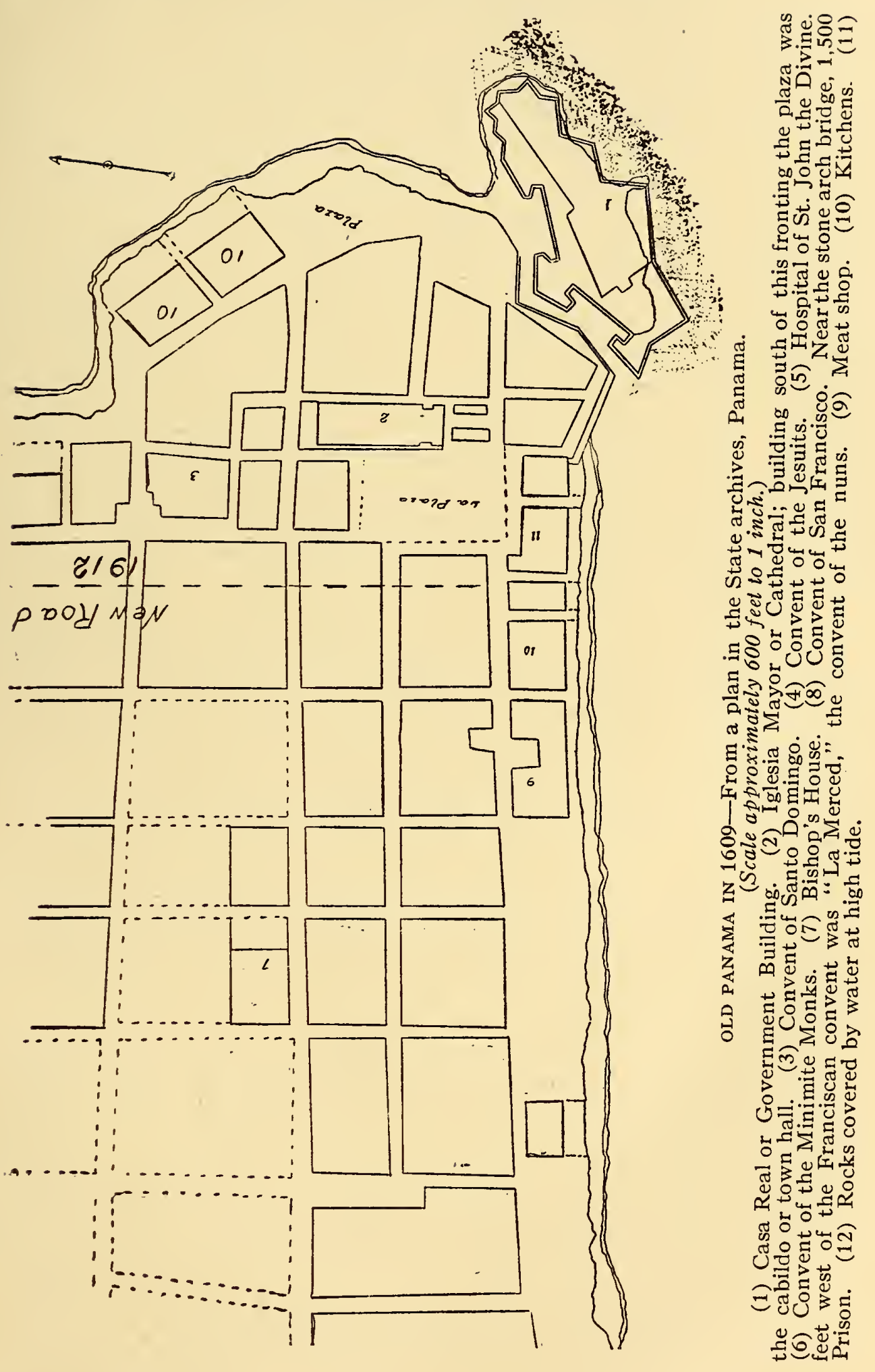


in America for a hundred years after Pizarro

Life in discovered Peru. And life could not have been Old Panama. dull there. Ships were constantly arriving from the north and south coasts of America, and from the Orient; the semiannual exodus of merchants to the fair at Porto Bello was an event of importance, not less interesting because each time some of the traders were sure to die there, so unhealthful was that place; the officials were always quarreling with one another; the slaves were running away and preying upon the pack-trains; there were many periods of want for food, because the colony was not self-sustaining, and depended upon Peru for foodstuffs. There were constantly recurring civil wars; the city was partially destroyed by revolutionists four times during its first century. Finally there was a flourishing illicit trade, and that is always exciting, as the tourist will find, when he tries to smuggle Panama hats through the United States custom house. Indeed the destruction of the old city was a result of this trade.

A Dutch apothecary named Esquemeling accompanied Henry Morgan on his expeditions from Jamaica during 1668-71, and going home to Holland wrote his story, which was published under the title, "Buccaniers of America." This book is interesting here principally because it tells of the taking of Porto Bello in 1668, of Fort San Lorenzo at the mouth of the Chagres River in 1670, and Old Panama in.1671.

After the fall of Fort San Lorenzo, Morgan and 1400 followers set out for Panama on January 9, 1671, taking the river route to Cruces. In circumstantial manner the druggistauthor tells of the advance up the river, how the Spanish outposts were deserted, all the food was destroyed or hidden, and the pirates were reduced to such hunger that they ate leather. All this in a journey through a forest that must have been alive with monkeys and birds, if not with wild hogs and other animals. After six days they arrived at Cruces, where they left the canoes. Af.ter one day's rest they marched toward Panama and appeared before that city at sunset of the ninth day. The narrative continues:

"On the tenth day (January 19, 1671), betimes in the morning, they put all their men to convenient order, and with drums and

trumpets sounding, continued their march directly

Attack towards the city. But one of the guides desired

Begun. Captain Morgan not to take the common highway that led thither fearing lest they should find in it much resistance and many ambuscades. He presently took his 
advice, and chose another way that went through the wood, although very irksome and difficult. Thus the Spaniards, perceiving the Pirates had taken another way, which they scare had thought on or believed, were compelled to leave their stops and batteries, and come out to meet them. The Governor of Panama put his forces in order consisting of two squadrons, four regiments of foot, and a huge number of wild bulls, which were driven by a great number of Indians, with some negroes and others, to help them.

The Pirates, being now upon their march, came to the top of a little hill. whence they had a large prospect of the city and campaign (champaign) country underneath. Here they discovered the forces of the people of Panama, extended in battle array and when they perceived them to be so numerous, they were suddenly surprized with great fear, much doubting the fortune of the day. Yea, few or none there were but wished themselves at home, or at least free from the obligation of that engagement, wherein they perceived their lives must be so narrowly concerned.

Having been some time at a stand, in a wavering condition of mind, they at last reflected upon the straits they had brought themselves into, and that now they ought of necessity either to fight resolutely or die, for no quarter could be expected from an enemy against whom they had committed so many cruelties on all occasions. Hereupon they encouraged one another, and resolved either to conquer, or spend the very last drop of blood in their bodies. Afterwards they divided themselves into three battalions, or troops, sending before them one or two hundred buccaneers, which sort of people are infinitely dextrous at shooting with guns. Thus the Pirates left the hill and descended marching directly towards the Spaniards, who were posted in a spacious field, waiting for their coming.

As soon as they drew near them, the Spaniards began to shout, and cry, Vira el Rey! God save the King! and immediately their horse began to move against the Pirates. But the Battle Before field being full of quags and very soft under foot, they the City. could not ply to and fro and wheel about, as they desired. The two hundred buccaneers who went before, every one putting one knee to the ground, gave them a full volley of shot, wherewith the battle was instantly kindled very hot.

The Spaniards defended themselves very courageously, acting all they could possibly perform, to disorder the Pirates. Their foot, in like manner, endeavoured to second the horse, but were constrained by the Pirates to separate from them. Thus finding themselves frustrated of their designs, they attempted to drive the bulls against them at their backs, and by this means put them into disorder, but the greatest part of the wild cattle ran away, being frightened with the noise of the battle, and some few that broke through the English companies did no other harm than to tear the colours in pieces whereas the buccaneers shooting them dead, left not one to trouble them thereabouts.

The battle having now continued for the space of two hours, at the end thereof the greatest part of the Spanish horse was ruined and almost all killed. The rest fled away, which

Prisoners being perceived by the foot, and that they could not Killed. possibly prevail, they discharged the shot they had in their muskets, and throwing them on the ground, betook themselves to flight, every one which way he could run. The 
Pirates could not possibly follow them, as being too much harrassed and wearied with the long journey they had lately made. Many of them, not being able to fly whither they desired, hid themselves for that present among the shrubs of the sea-side. But very unfortunately, for most of them being found out by the Pirates, were instantly killed, without giving quarter to any. Some religious men were brought prisoners before Captain Morgan, but he being deaf to their cries and lamentations, commanded them all to be immediately pistoled, which was immediately done.

Soon after they brought a captain to his presence, whom he examined very strictly about several things, particularly wherein consisted the forces of those of Panama. To which he answred: Their whole strength did consist in four hundred horse, twenty-four companies of foot, each being of one hundred men complete, sixty Indians and some negroes, who were to drive two thousand wild bulls and cause them to run over the English camp, and thus by breaking their files put them into a total disorder and confusion. He discovered more, that in the city they had made trenches, and raised batteries in several places, in which they had placed many guns, and that at the entry of the highway which led to the city they had built a fort, which was mounted with eight great guns of brass, and de. fended by fifty men.

Captain Morgan, having heard this information, gave orders instantly they should march another way. But before setting forth, he made a review of all his men, whereof he found both killed and wounded a considerable number, and much greater than had been believed. Of the Spaniards were found six hundred dead upon the place, besides the wounded and prisoners. The Pirates were nothing discouraged, seeing their number so much diminished, but rather filled with greater pride than before, perceiving what huge advantage they had obtained against their enemies. Thus having rested themselves some while, they prepared to march courageously towards the city, plighting their oaths to one another in general they would fight till never a man was left alive. With this courage they recommenced their march, either to conquer or be conquered, carrying with them all the prisoners.

They found much difficulty in their approach to the city. For within the town the Spaniards had placed many great guns, at several quarters thereof, some of which were charged

Defense of with small pieces of iron, and others with musketthe City. bullets. With all these they saluted the Pirates at their drawing nigh to the place, and gave them full and frequent broadsides, firing at them incessantly. Whence it came to pass that unavoidably they lost, at every step they advanced, great numbers of men. But neither these manifest dangers to their lives, nor the sight of so many of their own men dropping down continually at their sides, could deter them from advancing farther and gaining ground every moment upon the enemy. Thus, although the Spaniards never ceased to fire and act the best they could for their defence, yet notwithstanding they were forced to deliver the city after the space of three hours' combat.

The Pirates having now possessed themselves thereof, killed and destroyed as many as attempted to make the least opposition against them. The inhabitants had caused the best of their goods to be transported to more remote places. 
As soon as the first fury of their entrance into the city was over, Capt. Morgan assembled all his men at a certain place which

\section{Burning \\ of the \\ City.}

he assigned, and there commanded them under very great penalties that none of them should dare to drink or taste any wine. The reason he gave for this injunction was, because he had received private intelligence that it had been all poisoned by the Spainards. Howbeit it was the opinion of many that he gave these prudent orders to prevent the debauchery of his people, which he foresaw would be very great at the beginning, after so much hunger sustained by the way, fearing withal lest the Spainards, seeing them in wine, should rally their forces and fall upon the city, and use them as inhumanly as they had used the inhabitants before.

Capt. Morgan, as soon as he had placed guards at the several quarters where he. thought necessary, both within and without the city of Panama, immediately commanded twenty-five men to seize a great boat; which had stuck in the port for want of water at a low tide, so that she could not put out to sea. The same day, about noon, he caused certain men privately to set fire to several great edifices of the city, nobody knowing whence the fire proceeded nor who were the authors thereof, much less what motives persuaded Capt. Morgan thereto, which are as yet unknown to this day. The fire increased so fast that before night the greatest part of the city was in flame.

Capt. Morgan endeavored to make the public believe the Spaniards had been the cause thereof, which suspicions he surmised among his own people, preceiving they reflected upon him for that action. Many of the Spaniards, as also some of the pirates, used all the means possible either to extinguish the flame, or by blowing up houses with gunpowder, and pulling down others, to stop the progress. But all was in vain for in less than $\underset{*}{\text { an hour }} \underset{*}{\text { it }} \underset{*}{*}{ }_{*}$ a whole street.

The fire of all the houses and buildings was seen to continue four days after the day it began. The Pirates in the menawhile, at least the greatest part of them, camped for some time without the city, fearing and expecting that the Spaniards would come and fight them anew. For it was known that they had an incomparable number of men more than the Parties had. This occasioned them to keep the field, thereby to preserve their forces united, which now were very much diminished by the losses of the preceding battles, as also because they had a great many wounded, all of which they had put into one of the churches which alone remained standing, the rest being consumed by the fire. Moreover, besides these decreases of their men Captain Morgan had sent a convoy of 150 men to the Castle of Chagre, to carry the news of his victory obtained against Panama.

They saw many times whole troops of Spaniards cruize to and fro in the campaign fields which gave them the occasion to suspect their rallying anew. Yet they never had the courage to attempt anything against the Pirates. In the afternoon of this fatal day, Captain Morgan re-entered again the city with his troops, to the intent that every one might take up his lodgings, which now they could hardly find, very few houses having escaped the desolation of the fire. Soon after they fell to seeking very carefully among the ruins and ashes for untensils of plate or gold which peradventure 
were not quite wasted by the flames. And of such things they found no small number in several places, especially in wells and cisterns where the Spaniards had hid them from the covetous search of the Pirates.

The next day Capt. Morgan despatched away two troops o Pirates, of one hundred and fifty men each, being all very stout soldiers and well armed, with orders to seek the in-

The habitants of Panama who were escaped from the

Galleon. hand of their enemies. These men, having made several excursions up and down the campaign (champaign) fields, woods and mountains, adjoining to Panama, returned after two days' time, bringing with them above two hundred prisoners, between men, women, and slaves.

The same day returned also the boat above mentioned, which Capt. Morgan had sent to the South Sea, bringing with it two other boats which they had taken in a little while. But all these prizes they could willingly have given, yea, although they had employed greater labour into the bargain for one certain galleon which miraculously escaped their industry, being very richly laden with all the King's plate and a great quantity of riches of gold, pearls, jewels, and other most precious goods of all the best and richest merchants of Panama. On board of this galleon were also the religious women, belonging to the nunnery of the said city, who had embarked with them all the ornaments of the church consisting of a large quantity of gold plate, and other things of great value.

The strength of this galleon was nothing considerable as having only seven guns and ten or twelve muskets for the whole defence, being on the other side very ill-provided of victuals and other necessaries, with great want for fresh water, and having no more sails than the uppermost sails of the main mast. This description of the said ship, the Pirates received from certain persons who had spoken with several mariners belonging to the galleon, at such time as they came ashore in the cock-boat to take in fresh water. Hence they concluded for certain they might easily have taken the said vessel had they given her chase and pursued her, as they ought to have done especially considering the said galleon could not long subsist at sea.

But they were impeded from following this vastly rich prize by gluttony and drunkenness, having plentifully dèbauched themselves with several sorts of rich wines they found there ready to their hands. So that they chose rather to satiate their appetite with the things above-mentioned, than to lay hold on the occasion of such a huge advantage, although this sole prize would certainly have been of far greater value and consequence to them than all they secured at Panama, and other places thereabout.

The next day, repenting of their negligence, and being totally wearied of the vices and debaucheries aforesaid, they set forth to sea another boat well armed, to pursue with all speed imaginable the said galleon. But their present care and diligence was in vain, the Spaniards who were on board the said ship having received intelligence of the danger they were in one or two days before, while the Pirates were cruizing so near them, whereupon they fled to places more remote and unknown to their enemies. 
Notwithstanding, the Pirates found in the ports of the islands of Tavoga and Tavogilla (Taboga and Taboguilla), several boats that were laden with many sorts of very good merchandise all of which they took and brought to Panama where, being arrived, they made an exact relation of all that had passed while they were abroad to Capt. Morgan. The prisoners confirmed what the Pirates had said adding thereto, that they undoubtly knew whereabouts the said galleon might be at that present, but that it was very probable they had been relieved before now from other places.

These relations stirred up Capt.. Morgan anew to set forth all the boats that were in the port of Panama, with design to seek and pursue the said galleon till they could find her. The boats afores zid, being in all four, set sail from Panama and having spent eight days in cruizing to and fro and searching several ports and creeks, they lost all their hopes of finding what they so earnestly sought for.

* $*$ * * $\quad * \quad * \quad * \quad * \quad *$

Captain Morgan used to send forth daily parties of two hundred men to make inroads into all the fields and country thereabouts, and when one party came back, another consisting of two

Prisoners hundred more was ready to go forth. By this means

Tortured. they gathered in a short time a huge quantity of riches and a no lesser number of prisoners. These, being brought into the city, were presently pilt to the most exquisite tortues imaginable to make them confess both other péople's goods and their own.

They spared in these their cruelties, no sex or condition whatever. For as to religious persons and priests, they granted them less quarter than to others, unless they could produce a considerable sum of money, capable of being a sufficient ransom. Women themselves were no better used, and Captain Morgan their leader and com. mander, gave them no good example on this point.

On the 24th of February of the year 1671, Captain Morgan departed from the city of Panama, or rather from the place where the

said city of Panama did stand; of the spoils whereof

Pirates he carried with him one hundred and seventy-five

Departure. beasts of carriage laden with silver, gold and other precious things, besides six hundred prisoners, more or less, between men, women, children, and slaves.

There was a quarrel over the division of spoil, the men claiming that Morgan cheated them, and the Captain with a few followers sailed from Fort San Lorenzo about the end of March for Jamaica. Panama had been destroyed in time of peace between Spain and England, but this did not prevent the knighting soon after of Henry Morgan, who was made governor of Jamaica, and spent some of his later days in waging war against pirates. Old Panama was not rebuilt, and on January 21, 1673, the site of the present city was blessed in solemn manner, and the building of the walls was begun.

Sosa and Arce say that there is no doubt that the city 
was burned at the direction of the Governor who had various deposits of powder exploded for this pur-

Origin of the pose. By the end of the night on which the 'Fire. fire began, only some public buildings, a single chapel, and some of the outlying barracks for slaves remained safe from the flames. The public buildings referred to were doubtless built, at least in part, of stone, and the foundations of many of them may be seen today. They were not razed by the pirates, but were torn down by the Spaniards and the stone carried to new Panama, where they were used in building churches and the walls of the new city.

In addition to the treasure of romance that is hidden in the story of Old Panama, it is believed that there is buried there in some of the old wells and in cubby-

Buried holes in the walls, some of the wealth that

Treasure. escaped the pirates. Well, there may be. It is well to remember, however, that upon the approach of the pirates the king's treasure, and the ornaments from the churches were piled upon ships and sent to Peru. It is well also to remember that the pirates took away much booty (175 mule-loads it is said), and that after they left, the inhabitants of the place came back to the town and probably recovered what the pirates had not carried away. Notwithstanding this, many treasure hunts have taken place on the site of Old Panama, and if the tourist has time to do so he is advised to join in one. He will find nothing, but it will be worth his while to have it to "tell the folks at home" that he dug for treasure in Old Panama.

A monograph on Old Panama from the local viewpoint is in course of preparation by Samuel Lewis, a prominent citizen of Panama.

\section{Porto Bello.}

There is only one way to get to Porto Bello, and that by boat from Colon. A tug leaves the wharf at Cristobal every morning, and returns that night. In the two hours or more that one has at Porto Bello, between the arrival and departure of the tug, he can cross the bay from the American settlement and quarries to the old "city," as every fortified place was called.

Here he will find the best ruins in Panama, for Porto. Bello has existed continuously as a Spanish town since 1597, and until 1820 it was a garrison for troops.

Ruins. Its forts were destroyed and rebuilt many times. The present decay of its old build- 
ings is indicative more of the decay of trade than of the assaults of English and French privateers. Especially worthy of note will be found the beautiful remains of the old customs house, that guards one side of the plaza, the old bridges, the ruins of Fort San Jerome, and the pigs that keep guard in the old plaza.

In the present native village there are a church, several stores, and a hundred houses of a better type than are commonly found in native settlements. The population was 2,285 in 1911, in addition to about 1,000 in the American village at the stone quarries.

The site seems ideal both for habitation and defense. It was one of the two safe anchorages on the northeast coast of Panama found by the early Spaniards, the other being Nombre de Dios. At Porto Bello there is a break in the

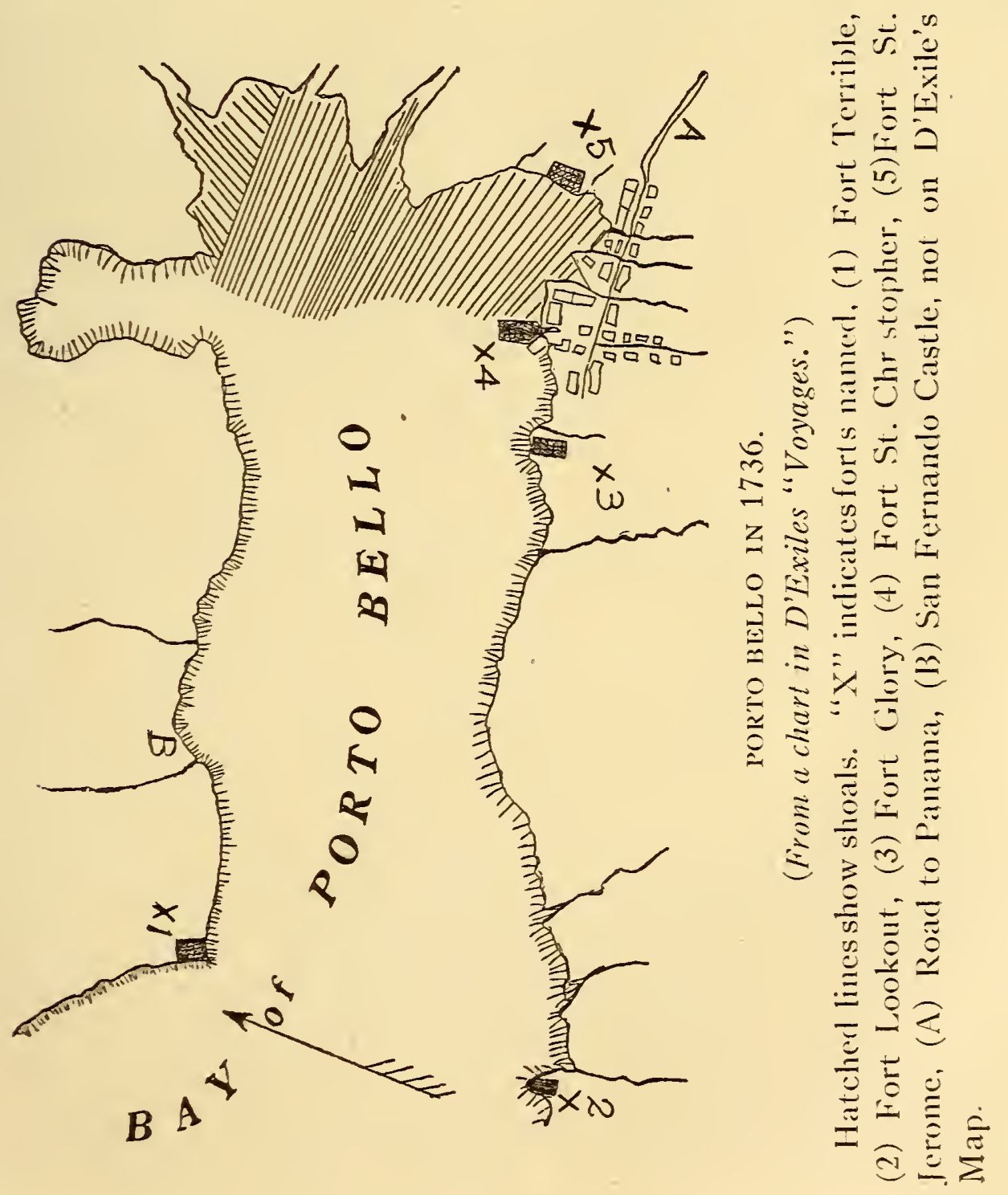


coast that looks like the mouth of a tidal river, and here is a bay $1 \frac{1}{2}$ miles long and 2,500 feet wide. A dozen little streams pour their water into this bay, and cut the surrounding hillsides with ravines. On the part farthest inland the old "city" was built, with outpost forts guarding either side of the entrance to the bay.

Old Porto Bello had a fearful name for unhealthfulness. This is probably due to the fact that the rainfall there is heavy (it amounted to 237 inches in 1909), and thus malaria-bearing mosquito es breed rapidly; and to the other fact that the people who lived there (mostly negro slaves) were dirty. The site is really ideal, because plenty of fresh water flows down from the hills, and the gulleys which these streams have cut through the townsite are natural sewers that are flushed every day by water from one of the constantly recurring showers.

A map is printed herewith showing Porto Bello in 1736, as it was at the time that D'Exiles wrote his "Voyages." It will be noticed that the site marked " $B$ " is referred to as an old fort. This fort does not appear on D'Exlies' map, but its ruins, still extant, show that it was a defense of some importance. The American quarries are between the sites of the forts XI and "B," and Fort Terrible (XI), af ter having withstood the assaults of English sailors, and at least two hundred years of constant rains, was dug up by a steamshovel in 1909. Part of it is now in the concrete of Gatun Locks.

Coasting along the north shore of the isthmus in the late fall of 1502 , Columbus entered a well protected bay, on one shore of which was an Indian village

Some Dates in of a score of palm-thatch houses arranged

Porto Bello's in regular order, while nearby were fruit trees

History. and garden patches. It was a welcome sight, and he called it Portobelo (fair port), because that was the way it looked to him. In later years when Indian and negro met in the jungle, the village became a cimarrone stronghold, and trails went out from it to the king's highway between Nombre de Dios and Panama. When the mortality at Nombre de Dios became so high as constant$1 y$ to attract notice, the King decreed (1584) that the royal port be changed to Porto Bello, where the harbor is better. It was not until 1597, however, after Drake had destroyed Nombre de Dios, that the change was actually made. On February 20 of that year, the town of San Felipe de Porto 
Bello was laid out, and the fortifications were planned, the construction of Fort St. Philip being the first begun. As the port at which the King's treasure was stored, Porto Bello was naturally the object of frequent attack, and as naturally it was well fortified to resist attack. Many an English and French pirate sailed past the harbor and feared to attack the city; many a "free trader" anchored in the cove nearby, and notified the officials within the walls, and through them the merchants at Panama, that he was there to sell goods that would not be burdened with the King's tax.

Fort St. Philip had just been completed, and work was in progress on the second fort, St. James the Glorious (La Gloria), when the city sustained its first attack. On February 7,1602 , the buccaneer William Parker surprised the place and, breaking into the king's warehouse, stole gold valued at 10,000 ducats. The fort of St. Jerome was built in 1660 . In April, 1663, a fire burned 43 houses.

In June, 1668, Morgan and his band of cutthroats took the place, burned such buildings as would burn, pillaged the storehouses, and put many of the people to death. The story of this attack, and of the carnage that followed, is told by Esquemeling, and is entertaining in its way. But it is so much a duplication of what is told of the taking of Old Panama, that it is not worth while to repeat it here. In 1681 , the work of rebuilding the forts, battered in the assault and subsequent occupation by the pirates, was begun.

On November 22, 1739, the expedition under Vernon, sent out from England during war with Spain to harry the trade of the Spanish Main, took the city with little resistance. Almost as easily on April 25, 1742, Vernon took it again, and held it two months as a base for his intended expedition against Panama. These attacks by Vernon were so faintly resisted that the forts and buildings suffered little. They were badly battered, however, on August 2, 1744, when an English pirate, William Kinghills, in retaliation for attacks on contraband trade, entered the bay under guise of friendship with 40 vessels, and turned 500 guns broadside on the city. The galleons had not called at Porto Bello since 1739 , and the city walls and buildings were never fully restored after Kinghills' vandal attack.

During the wars for independence from Spain, Porto Bello was unsuccessfully attacked by the Colombian revolutionists in January, 1814. On April 9, 1818, Gregory Mac MR 22928-—13 
Gregor, a soldier of fortune commanding two ships and 417 men recruited in England, took Porto Bello; but on the 28 th of that month the place was retaken by the Spanish, and 340 English prisoners were set to work in repairing the forts.

Porto Bello ceased to be important as an entrepot with the end of the galleon trade. When steamship traffic was begun with the isthmus (1839) the ships unloaded at the mouth of the Ghagres, whence the river route was followed to Cruces. This also was the place of disembarkation for immigrants to California and Oregon, and a few years later for the gold-seekers of the "fifties." The completion of the Panama Railroad killed what little chance Porto Bello had of resuscitation as a trade center. The trail to Panama is still open, but it is used only by the country people in their local communication.

In the section of this book given to a summary of the Privateers and Buccaneers attention is called to the fact that they had begun their assaults on Spain's

Porto Bello commerce, as early as 1550. By 1565 these

Fairs. inroads had become so grave that a royal decree was issued forbidding Spanish merchantment to sail alone. They were forced to set out twice a year in fleets from Spain, rendezvous at a central point in the West Indies, and from there depart in smaller squadrons to the fairs at Vera Cruz, Habana, Cartagena, Porto Bello, and other points. Having made their trade they must return to the rendezvous in order to set out for Spain in large fleets.

Therefore it was only twice a year that the fleets of Spain called at Porto Bello to take away "the king's treasure," and to trade with the merchants of Panama. The town was large enough to accommodate only its normal population, composed of negro slaves and the garrison, with a few officials to represent the government. It was the custom in Europe to do trade at annual or semiannual fairs, and this custom was continued at Porto Bello. Treasure was stored there the year around, and there were warehouses; but generally the procedure was for the merchants at Panama to go to Porto Bello at the times the fleet might be expected. After its arrival the trade was done in a fortnight, everyone hurrying as much as possible, because the town was overcrowded, and the mortality was high. Writing 
of it as it was in 1637 (only 40 years after it was made the king's port), Thomas Gage says:

"For the town being little and the soldiers that come with the galleons for their defense at least four or five thousand, besides merchants from Peru, from Spain, and many other places, to buy and sell, is cause that every room, though never so small, be dear; and sometimes all the lodgings in the town are few enough for so many people, which at that time do meet at Porto Bello. I knew a merchant who gave a thousand crowns for a shop of reasonable bigness, to sell his wares and commodities that year I was there, for fifteen days only, while the fleet continued to be in that haven. I visited the castles which indeed seemed unto me to be very strong; but what most I wondered at was to see the requas of mules which came thither from Panama, laden with wedges of silver; in one day I told two hundred mules laden with nothing else, which were unladed in the public market place so that there the heaps of silver wedges lay like heaps of stones in the street, without any fear or suspicion of being lost. Within ten days the fleet came, consisting of eight galleons and ten merchant ships, which forced me to run to my hole (lodging). It was a wonder then to see the multitude of people in those streets which the week before had been empty. Merchants sold their commodities not by the ell or yard, but by piece and weight, not paying in coined pieces of money, but in wedges which were weighed and taken for commodities. This lasted but fifteen days while the galleons were lading with wedges of silver and nothing else, so that for those fifteen days I dare boldly say and avouch that in the world there is no greater fair than that of Porto Bello between the Spanish merchants and those of Peru, Panama, and other places thereabout.

Esquemeling writes of Porto Bello as it was when the pirates under Morgan tock it in June, 1668:

"It is judged the strongest place the king of Spain possesses in all the West Indies, except Havanna and Carthagena. Here are two castles almost impreznable, that defend the city, situate at the entry of the port, so that no ship or boat can pass without permission. The garrison consists of three hundred soldiers, and the town is inhabited by about four hundred families. The merchants dwell not here but only reside awhile, when the galleons come from or go for Spain, by reason of the unhealthiness of the air, occasioned by vapours from the mountains; so that though their chief warehouses are at Puerto Bello, their habitations are at Panamá, whence they bring the plate upon mules, when the fair begins, and when the ships belonging to the company of negroes arrive to sell slaves."

During the first, second, and third fifty years of its life, then, Porto Bello did not change greatly. It was a fortified harbor where the isthmian traders met twice a year to buy and sell with Spanish merchants, although its trade decreased constantly from the first half of the 17 th century. It was a garrisoned place in 1740 when the English under Admiral Vernon silenced its guns. in 
1810, according to Restrepo, it was well fortified and garrisoned. Since the wars of independence, however, it has had little strength although a small garrison was-kept there up to 1860 .

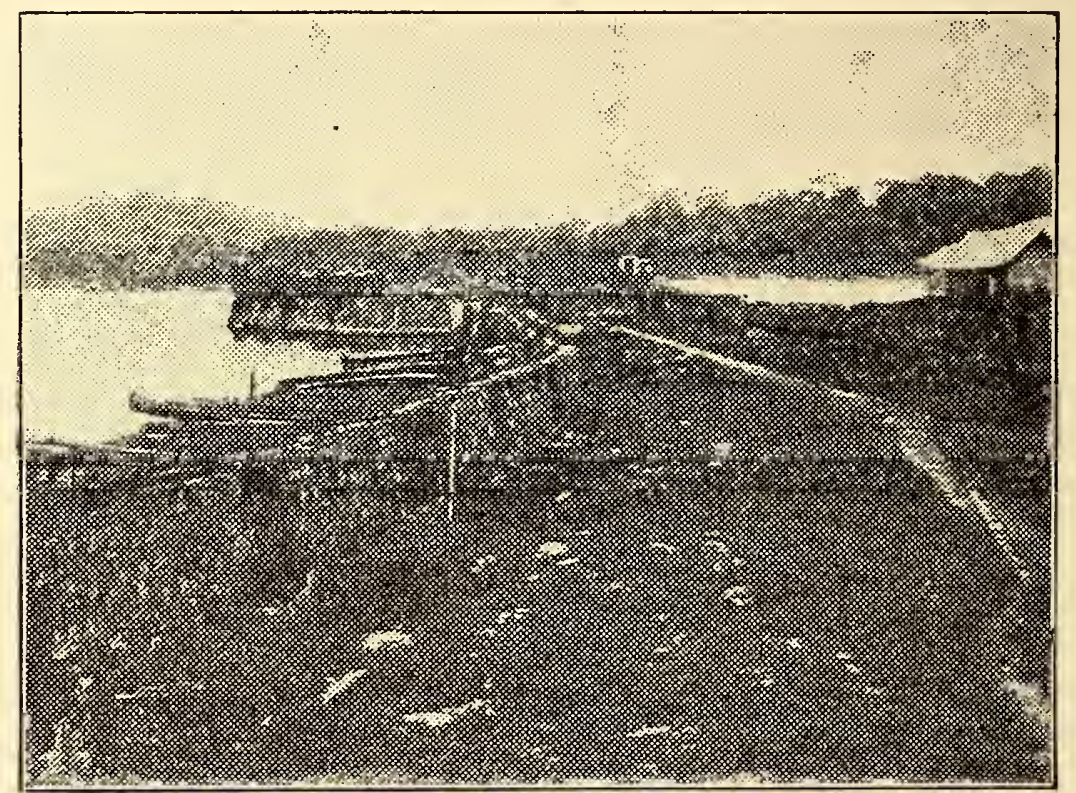

CASTLE SAN JEROME-PORTO BELLO.

There is no stopping place in the story of Porto Bello, as in that of Old Panama, and although this chapter has to do chiefly with the old, the story may as Porto Bello well be finished here. It is in Panaman terToday. ritory, 18 miles northeast of Colon, is the seat of a local municipality of the same name, and the center of a small coasting trade. On the south side of the bay is the native town, to which reference has already been made, and on the north side the American settlement at the rock quarries.

The rock in the hills here is hard and easily enough crushed to make it a desirable rock for concrete; the water haul to Gatun makes the carrying of the rock easy.

Porto Bello Therefore it was decided early in the canal Quarries. history, as soon as the lock type had been agreed upon, to use rock from Porto Bello for the locks at Gatun. Preliminary work was carried on in 1907 and 1908, and the first rock was crushed on March 2,1909 . Since then the plant has worked practically continuously. It must crush $2,250,000$ cubic yards of rock for 
the concrete at Gatun Locks and Spillway, and in addition there will be supplied from the quarry, 4,500,000 cubic yards of large rock for the armoring of the breakwater at the Atlantic entrance to the canal.

The quarries are on the side of a hill that rises almost sheer from the water, on the north shore of the bay, well inside of the harbor. After it is quarried, the rock is conveyed in dump cars direct to the crusher plant, which consists of two No. 9, four No. 6 McCully gyratory crushers, and one large crusher which takes rock any size the steamshovels can handle. Pan conveyors take the crushed rock from the crushers to a hopper beneath the shipping bin, located on the water line. This hopper empties into a double distributing bucket-conveyor which elevates the crushed stone and delivers it by means of a tripper at the points desired in the bin. The storage bin has a capacity of 2,500 cubic yards, and from this bin the stone is loaded into barges by gravity; each barge has a capacity of 600 cubic yards. These barges are towed to Cristobal and thence through the old French canal to Gatun.

The new village of Porto Bello is a typical canal-workers' settlement, with employes' quarters, a clubhouse, dispensary and hospital, sewer, water system, and electric lights. By agreement with the Republic of Panama the Canal Zone police keep order in the American settlement, although all persons arrested are turned over to the Panaman courts. The United States Navy maintains a wireless telegraph station here.

\section{Fort San Lorenzo.}

How to Get There are two ways to get to Fort San There. Lorenzo, at the mouth of the Chagres Riverone by sea from Colon, and motor boats are available to take the tourist; and the other by way of the river from Gatun.

The latter is the more interesting trip, because it involves a ride of ten miles by way of the Chagres. This is one of the few bits of the tropics in Panama that comes up to the ideas the wood-prints in the old geographies gave us. Here one sails through a tidal estuary between banks thick with jungle, giant bamboo bends over the water, and the trees are heavy with great vines and orchids. Here and there, in the dry season, one sees a lonely lignum vitae, discovered by its brilliant yellow top, the espeve towering above all others, and 
the cottonwood apparently as strong as a concrete column, but really one mass of pulp. Of less height but as picturesque are the various palms that reach their many-fingered leaves above the jungle mass, the most common being the corozo, from a species of which is obtained the palm oil of commerce.

On the other hand, the sea route affords the best view of the old fort or castle, standing above the river mouth in apparently impregnable position.

It is nearly a hundred years since the Spaniards evacuated San Lorenzo, in common with other isthmian posts, and the fort has not been used for a garrison since then. The little village of Chagres, at the foot of the castled hill, is the seat of an alcaldia, the capital of the district around about. It has neither industries nor commerce, except for local purposes.

- The fort that one sees today is not that which the pirates under Morgan successfully stormed, but a castle of later period, resembling much the old forts at the

The Old Fort. entrance to New York harbor. It represents the architecture of a period just prior to the introduction of rifled ordnance. No other ruin in Panama is more complete than this, because one may see every line of the old castle. There are two lines of defense, an outer wall, and the castle proper, the latter to be entered by a drawbridge, and the place for the bridge is still seen in the old tower. In the courtyard is the water reservoir, and at various places in the walls are found especially strong rooms where it is believed ammunition for the gun service was stored.

In a cave-like gallery under a cover of heavy masonry, with no pavement but the mud, and very few holes to let in light or air, is the place where the soldiers

Prison. of the garrison used to sleep. Two short galleries running off from this larger one were used as prisons. There remain here some of the old manacles, and one may see the instruments and means by which prisoner's were made secure in the old fort a century or more ago. They are similar to the instruments used in English madhouses about the time that Dickens wrote. The favorite form seemed to be to seat a man against the wall and place his neck in an iron collar built in two sections, one fastened to the wall and the other hinged upon this. About the only exercise one could take while in this position 
would be thinking, and the prisoners had many hours for this pursuit. There are also manacles for the ankles and arms, ball and chain, and other refined methods of holding one secure. Each of these cells has a little window at the daylight end, through which nothing larger than a dachshund could possibly escape. The only other chance then of getting away was through the barracks where the garrison sleeps. The tourist is strongly advised to visit Fort San Lorenzo, because it will make him so much more contented with the time in which he lives.

The Chagres River was explored in 1527, and within a few years it was used by boats making for the royal port at Nombre de Dios, about 50 miles eastward of the river mouth. Its use became more general when Porto Bello was made the royal port, because this place is only 30 miles from the river mouth, and also because the river and sea route were free from the attacks made continually along the trails by the cimarrones. Yet Chagres was only an outpost. Here some canoes broke cargo to load upon the armed sailing vessels that plied between Porto Bello and San Juan de Nicaragua, but more frequently they rounded the point and made for the royal port under their own sail. The north coast waters can be safely navigated by canoes eight months of the year.

The depredations of Drake and his followers along the north coast of the isthmus, and the ease with which he landed his troops at the mouth of the Chagres led to the building of Fort San Lorenzo as a guard to this back door of Panama. Juan Bautista Antonelli, a Roman engineer, made the plans both for this fort and for the defenses of Porto Bello. It is believed his plans were not carried out fully, because the fort built was not substantial, and but for its position on a steep hill would have afforded little protection. The work was completed about 1601 , and yet only one generation later (1637) Thomas Gage reports the place as crumbling to ruin. He did not stop there, however, and may have been deceived as to its real condition by seeing portions of the walls, which were made of mud filled between rows of stakes, falling away. It is probable, too, that it had been strengthened after the taking of Porto Bello in 1668, because at that time Morgan warned the Governor of Panama that he intended to take that city.

On January 6, 1671, Morgan sent ahead of his regular fleet of 37 ships and 2,000 men, one of his officers, Capt. 
Joseph Brodley with four hundred men charged with capturing San Lorenzo, which was garrisoned by 300 men. Esquemeling describes the fort as follows:

This castle is built upon a high mountain, at the entry of the river, and surrounded on all sides with strong palisades or wooden walls, being very well terrepleined, and filled with earth, which renders them as secure as the best walls made of stone or brick. The top of this mountain is in a manner divided into two parts, between which lies a ditch, of the depth of thirty foot. The castle itself has but one entry, and that by a drawbridge which passes over the ditch aforementioned. On the land side it has four bastions, that on the sea containing only two more. That part thereof that looks towards the south is totally inaccessible and impossible to be climbed, through the infinite asperity of the mountain. The north side is surrounded by the river, which hereabouts runs very broad. At the foot of the said castle, or rather mountain, is seated a strong fort, with eight great guns. which commands and impedes the entry of the river. Not much lower are to be seen two other batteries, whereof each hath six pieces of cannon, to defend likewise the mouth of the said river. At one side of the castle are built two great storehouses, in which are deposited all sorts of warlike ammunition, and merchandize, which are brought thither from the inner parts of the country. Near these houses is a high pair of stairs, hewn out of the rock, which serves to mount to the top of the castle. On the west side of the said fortress lies a small port, which is not above seven or eight fathoms deep, being very fit for small vessels and of very good anchorage. Besides this, there lies before the castle, at the entry of the river, a great rock, scarce to be perceived above water, unless at low tide.

The assault of the pirates was made from behind-that is, from the land side, and was being repelled successfully, until one of the pirates shot a burning arrow into the group of thatched buildings in the center of the enclosure, and set them afire. The Spaniards were unable to hold out against both foes, and finally after the death of their commander what was left of the three hundred (only 30 men, 20 of whom were wounded) surrendered. Morgan came up a few days later and made San Lorenzo the base for his expedition up the Chagres against Panama. Upon his return from Panama he dismantled the guns of the fort and had them carried aboard his ships, demolished as much of the masonry as he conveniently could; and in general tried to destroy San Lorenzo.

The fort was restored after the taking by the pirates and made stronger. Yet it was forced to yield to the overwhelming force of Admiral Vernon on March 24, 1740, when he silenced its guns in order to establish there one of his bases for the contemplated expedition against Panama.

Under Colombian rule forts of the isthmus would be well kept up and garrisoned at times, and again they would 
be practically abandoned. San Lorenzo went through the common experience, but usually there was a garrison at the mouth of the Chagres. Restrepo says that in 1810 the 3,800 regular troops of the viceroy of Santa Fe de Bogota were distributed among the fortifications of Guayaquil, Panama, castle of Chagres, and plaza of Porto Bello. These stations so securely held helped to delay the revolution in Panama ten years.

When Panama ceased to be the great trade route in the middle of the 18th century, the Chagres naturally became of little consequence. It enjoyed a revival, however, in 1844 when the Ghagres mouth became one of the ports of call for the Royal Mail steamships plying between Southampton

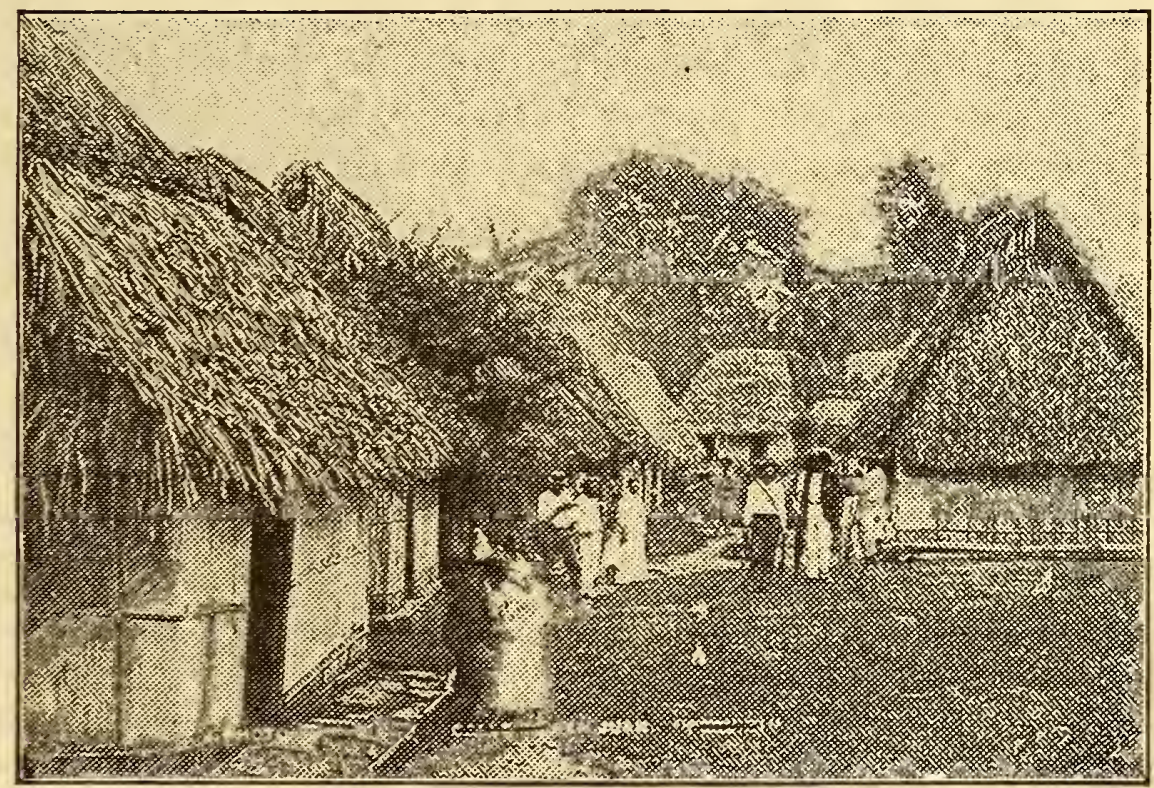

and Latin America. All the emigration from the United States and Europe that flowed towards the newly opened lands of Oregon and California passed this way, and San Lorenzo looked down upon the largest settlement that had ever clustered at the base of its hill, for the village of Chagres of ten sheltered as many as 2,000 people in one night. In November, 1851, the first steamship discharged its passengers at Colon and since then the Chagres mouth and San Lorenzo have been interesting only historically, not important at all. 


\section{Other Historic Places.}

The founding of Nombre de Dios in 1519, upon the abandonment of the Darien crossing, is referred to on page 108 . It remained the royal port, the place whence

Nombre de the galleons took their gold and silver to Spain, Dios. until 1597, when in obedience to a decree of 1584, and after the sack by Drake, the whole population removed to Porto Bello. There were four good reasons for this-the harbor is not so safe as that at Porto Bello, the place is not so easily defended, it is farther from Panama, and it had become so unhealthful that is was commonly called "the sepulchre of Spaniards."

During the years when it was the royal port some defenses were built along the water's edge, made of rows of sticks, probably bamboo, with earth filled between the rows. The time had not yet come when English and French pirates were bold enough to attack well defended cities, and therefore not much attention was paid to the fortifications. In fact, Drake was one of the earliest of the privateers who attacked fortified places. In 1572, he disembarked near Nombre de Dios and, approaching the city by some small boats which he had carried with him from England, got safely past the cannon at the water's edge, merely by answering the sentry's challenge in Spanish, and after a brisk fight in the plaza, in which he was wounded, took the town. The wounding of the leader, however, caused a panic and the English made for their ships, carrying Drake with them. A large store of treasure within their reach was untouched. A few months later Drake landed again near Nombre de Dios, and made his way through the jungle to a place nearby, where he lay in wait for the treasure train from Panama. The pack-train was apprised of the nearness of the marauders by the defection of a cimarrone, and again Drake had to leave without booty. In March, 1573, however, he made another attack on a pack-train near Nombre de Dios; and carried away a large quantity of gold and silver.

After this the place was strengthened so as to resist the attack it was expected Drake would make in 1585 , during an expedition to the West Indies. He did not go near the place, but in 1595 he set sail from England with 27 ships and 2,500 men for the avowed purpose of taking Panama. The Spaniards prepared for the advance. The plan was to take Nombre de Dios, and hold the mouth of the Chagres, then to send two expeditions inland, one by trail and the other by 
the water. One of these expeditions set out on the trail, but is was so harassed along the route that it retired. Everywhere were evidences of preparedness, and Drake gave up the attempt. On January 15 , he burned the village of Nombre de Dios, and sailed down the coast to Porto Bello where he died February 7.

A few years ago a dredge was sent to Nombre de Dios to dig sand for the concrete of the locks at Gatun. After digging for some time into the sandy beach it unearthed a quantity of old bullets, some silver, and ship's iron. It was said by the dredgemen that they encountered a large obstacle that resembled the hull of a ship. These objects dug up from the sand are all that remain to remind one of the days when Nombre de Dios was the royal port. Today it is the site of a native village, and a coconut grove is being set out there by a Colon merchant. Over a million cubic yards of sand have been taken from the beach and used in Gatun, Locks, and its value is many times greater than all the booty the English took away.

On the map which was published with Esquemeling's narrative in 1683 two large crosses appear at the point of the Chagres River where the boats unloaded

Cruces. their freight for carriage overland to Panama. These crosses are probably the origin of the name Las Cruces, which means "the crosses." The village was important, but never in its own right. It was the embarkation point for freight from Panama down the river and the point at which freight upbound was transferred to mule back. There were few storehouses at this point, and in fact it was only a village where boatmen, mule drivers, and cargomen lived. One may see there today two old bells, apparently left there on the way to Panama, and two old anchors with 14-foot shanks, likewise left there in transit. In 1911 it was proposed to remove the anchors to West Point but the untimely publication of the project led to a protest at Washington, and the anchors were allowed to remain where they have been for at least three centuries. Cruces of the present is a hamlet of Spanish and English negroes which smells bad in dry weather and is very muddy in the rainy season.

New

At the point on the San Blas coast of

Calidonia. Panama marked on the map on page 59,

"Calidonia Bay," a band of Scotchmen struggled for 18 months in 1698-1700 to establish a free trading 
colony right in the heart of the Spanish Main. One more failure was the result.

At Puerto Escosces (Scotch Harbor) today there is a settlement of Panamans; and the teacher of the village school, when asked about the Scotch colony recently, answered-"It was long ago; no one here remembers when." In a chapter of his book on Panama, Albert Edwards tells charmingly the story of the attempt, and the reasons why it failed. The scheme was originated by that William Paterson who made the plan for the Bank of England, and was fostered by the Scotch parliament in an effort to divert to Scotland some of the world-trade which the East India Company had centered in London. The determined opposition of the East India Company forced the new project to raise funds only in Scotland; just as the railroad companies of today were able to smother the project for an independent line of American ships to use the Panama Canal. Therefore from the start the colony was short of funds.

The first expedition sailed from Leith on July 26, 1698, and on November 1 landed at the harbor where Pedrarais had built the village of Acla. Internal dissensions, sickness, and opposition from England discouraged the colonists, who lacked a real leader, and they left their village of "New Edinburgh" and its half-built "Fort of St. Andrew," in June, 1699. On August 13 of that same year, a reinforcing party arrived at New Edinburgh, but finding the place deserted they sailed away, only 12 of the 300 who set out from Scotland remaining.

On November 30, 1699, another expedition, this time four ships and 1,200 colonists, arrived and joined the dauntless twelve. Albert Edwards follows Sir John Dalrymple in alleging that the colonists were divided among themselves by selfish ministers of the Scotch church. But without the internal differences, they were bound to fail. For four months they fought sickness, starvation, Spaniards, and one another. Finally a strong Spanish fleet began a blockade, while a land force invested the town. The colony surrendered "with honors of war," and on April 11, 1700, sailed away, most of them to become indentured servants in Jamaica and Barbados. Says Albert Edwards:

"The Company of Scotland, trading to Africa and the Indies was bankrupt. They had squandered 2,000 lives and over $£ 200,000$ on Paterson's dream. But the dreamer recovering from the fever in New York, returned to Scotland 
and became again the practical man of affairs. Paterson spent the remainder of his life in a successful effort to pay back twenty shillings to the pound on this immense debt."

The section of Panama between the Tuyra and Chucunaque Rivers and the border of Colombia is known by the term "The Darien." It is a region rather

Old Darién. than a definitely bounded territory. Through this land, over its high mountains and through its primeval forests and dense jungles, Balboa made his way with his little band of 76 Spaniards and a few score friendly Indians in the year 1513. From the top of one of its hills he first saw the Pacific, or that part of it which he called the Gulf of St. Michael (Gulf of San Miguel). Here he made friends with the Indians, heard stories about the islands rich in pearls, and the gold-heavy land southward, later called Peru. He stood on the shore of the Pacific in Darien and looked across to the islands, which he called the Pearl Islands, as they are called today. He named the largest one Isla Rica (Rich Island), which is now known as Rey Island, the king of the group. Through the Darien, Morales and Pizarro later made their bloody way to visit the Pearl Islands, and brought back to Acla the traditional basket of pearls.

From the time of Pizarro to this the Darien has been closed to all white men, except those who forced a way. The old route was abandoned when Panama was founded, in 1517. In the section near the Tuyra River, however, the Spaniards maintained posts, and it was here that they worked many mines by slave labor. But it was always at the cost of continual war, for the Indians were hostile and relentless.

In 1786 , a systematic attempt to colonize this rich region was begun. Three strong posts were established on the Atlantic side, on the Gulf of Uraba, Calidonia Bay, and an inland post, Carolina del Darien. On the Pacific side the fort of Principe was built, and posts on the Tuyra, Sabanas, and Chucunaque were established. Meanwhile a new viceroy came into power at Bogota, and in 1789 the posts were abandoned and destroyed by the Spaniards. They had already made a treaty of peace with the Indians, whose caciques had sworn allegiance to the King of Spain, and work had been begun on a highway that was to connect the Gulf of San Miguel with Calidonia Bay. This was the last attempt to colonize the Darien. 
Today the country is virgin land, except along the principal rivers near the Gulf of San Miguel, where there are some plantations, and at Cana, where gold is mined. More about "the Darien" will be found in the section on The Republic of Panama.

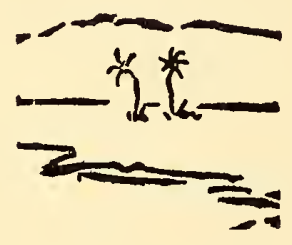




\title{
Miscellaneous Information.
}

\author{
Things Not True.
}

It is difficult to get an absolutely uncolored statement of fact from anyone, and especially difficult from an American in Panama. Most of us came to the Isthmus from very narrow lives in the States, and, thrown at one fling into an absolutely new life, our imaginations became at once unbalanced. In many cases, they have remained so. It is, therefore, not too much to say that many of the tales told tourists are untrue. Among the more common are the following:

"Balboa Hill" at Gorgona is really Cerro Gigante (the great hill). Balboa never saw it. He crossed the Isthmus from the San Blas coast to the Bay of San Miguel, fully 120 miles east of the so-called "Balboa Hill." It is 1,149 feet high.

The Death Rate during the construction of the Panama Railroad was not so high that the road cost a life for every tie. Gen. Geo. W. Davis, first Governor of the Canal Zone, has figured it out that this would have been 140,000 deaths in a labor force that never numbered over 7,000 , and was engaged only five years. The death rate in the days of the French Canal Companies is also greatly exaggerated.

The Sloth pointed out to the tourist as a black thing hanging from a tree is really an ants' nest. The sloth does hang from a tree, but not alongisde the railroad tracks or highways.

Free Quarters, lights, and fuel are not furnished canal employes. These form part of the contract the employe makes with the Government and are just as much a part of his pay as his monthly salary.

The United States Gave Panama nothing. It paid $\$ \mathbf{1 0 , 0 0 0 , 0 0 0}$ for a permanent lease of the Canal Zone and the right to exercise sovereignty therein. After 1913, it will pay a rental of $\$ 250,000$ a year. It laid pavements, put in water systems, and sewers, and the Panamans are paying for this work, with interest. The United States has been liberal in its deal- 
It is easier to copy Colgate Packages than to match Colgate Quality

To remove hot weather stickiness and make dressing comfortable use COLGATE'S TALC

Five delightful perfumes
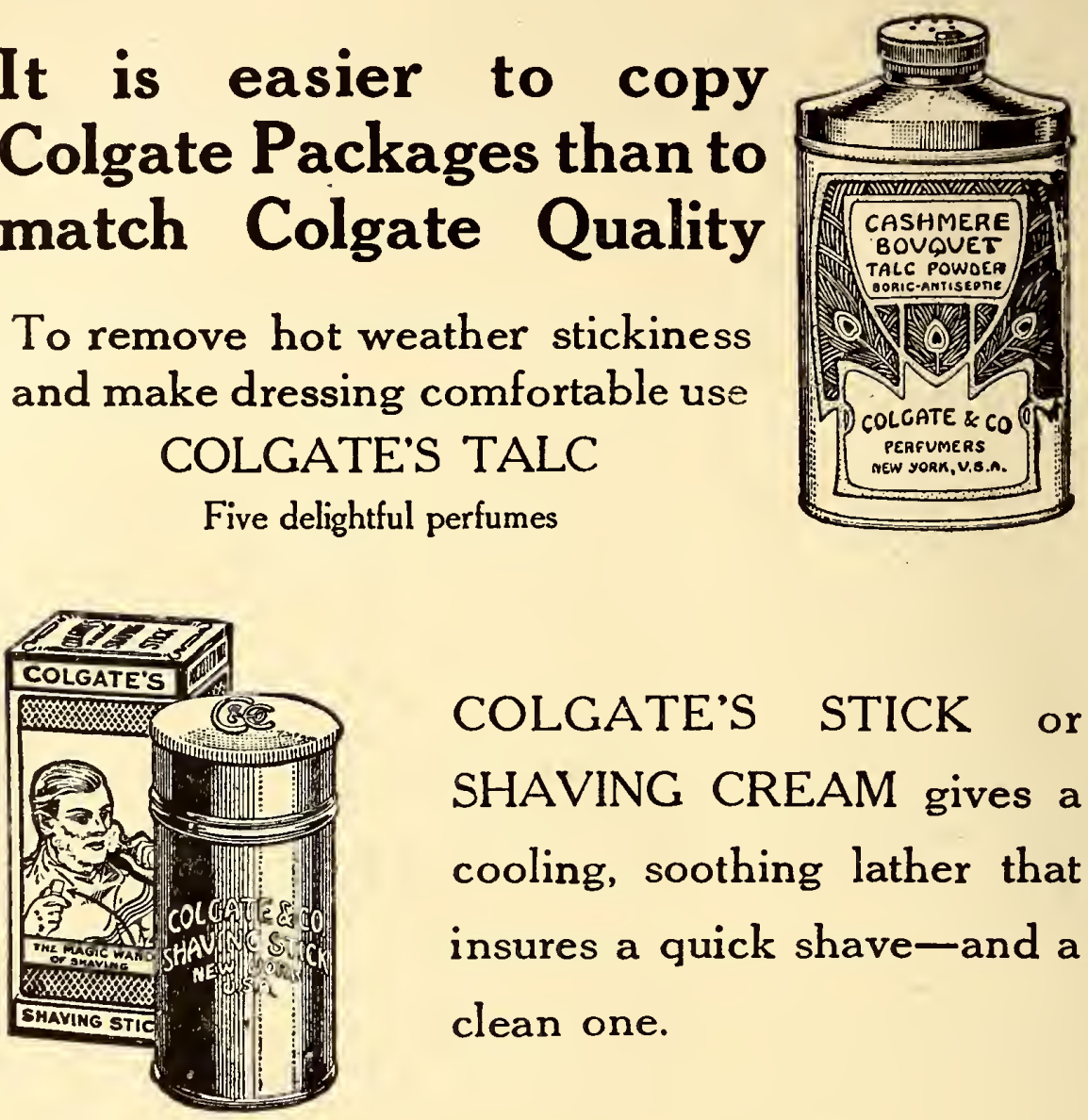

COLGATE'S STICK or SHAVING CREAM gives a cooling, soothing lather that insures a quick shave-and a clean one.

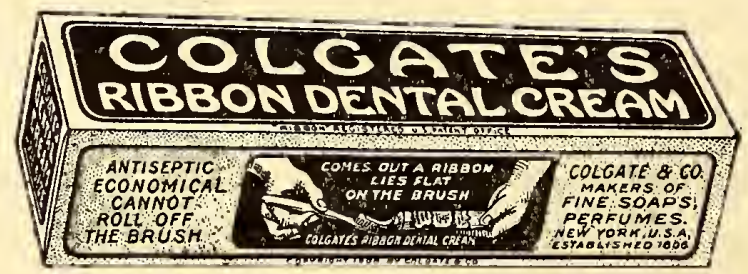

A delicious dentifrice that cleans the teeth and refreshes the mouth.

"Colgate Comforts" on sale at all dealers

COLGATE \& CO.

Established 1806

Makers of Cashmere Bouquet Soap-luxurious, lasting, refined 
ing with Panama, but it made in the beginning and has made ever since very good bargains. It got it's money's worth.

Locomotives were not dumped into the Black Swamp, but a few od French dump-car bodies were, in an effort to make a broad-bottomed mass that would float upon the soft mud of the swamp.

Panama currency is not on a silver basis. The standard is the gold balboa equal to the United States dollar. Only pesos have been coined, however. The "dollar silver" does not pretend to be a dollar, but, as its legend indicates, is "fifty hundreths of a balboa."

Polite Americans are not disliked by Panamans, but the kind of hoodlum that enters the churches with his hat on, pries into the homes of the people as he passes along the street, speaks of the people in their hearing as "spiggoties" or "niggers," is looked upon as a "pig," although pigs are usually not so ill-behaved.

\section{Trees and Plants.}

The part of Panama that the traveler sees, the Isthmus proper, has little vegetation indicative of that which characterizes the less settled portions of the country. The route along which the tourist travels has been cleared and burned over for four hundred years, and hardwood trees get little chance in a region so subjected to change. Here and there, however, one sees a lignum vitae standing alone in the jungle, and in the dry season when its top is covered with yellow blossoms it makes a brilliant sight.

A writer in a recent number of Harper's Weekly told in enthusiastic terms of the wonderful future for furnituremaking along the banks of the Canal, picturing the region as thick with cabinet woods. As a matter of fact there is scarcely enough hardwood in any one mile along the Canal, to build furniture for one home. The more common trees along the route are the mango, characterized by its leaves of green, yellow, and brown; the espeve which the natives hew out for canoes; the cocobolo, which is so hard as to make good knife handles; orange and lime; coconut, and other palms of various kinds, the corozo being the most common. The royal palms seen here and there were brought to Panama from Cuba in 1883.

There is a wild profusion of ferns and grasses, the most beautiful being the bamboo, which grows in clumps along 


\section{ASPINWALL HOUSE ESTABLISHED 1877}

\section{ENGLISH TWEEDS} AXD -

\section{SERGES}

IRISH : : LINENS

COMPRISING:

Drills, Ducks, Sheetings, Handkerchiefs, etc.

\section{Indian Fibre Bags}

Full line of Dry Goods and Notions

$$
\text { Piza, Piza \& Co. }
$$

Avenida Central and 8th Street, Panama 
the streams; the most profuse, the wire grass that grows abundantly in damp places; the kind that attracts most attention from the tourist, the papyrus. Wild cane grows in abundance in various sections along the river bottoms.

The most noticeable decorative plants are the bougainvilla, croton, and ferns of great luxuriance of growth and scores of varieties. A great favorite among the Americans on the Isthmus as a decorative plant is the orchid in one or more of its scores of forms. There are two varieties especially affected because they are considered very rareSpiritus Sanctus, and Lady of the Night. The Spiritus Sanctus is a white bell enclosing a stamen formed like a dove, and the resemblance is remarkable. The Lady of the Night is so called because it is said to be fragrant only at night. The best collections of orchids on the Isthmus are said to belong to Dr. J. C. Perry, of Ancon, and Mrs. H. H. Rousseau and Mrs. D. D. Gaillard of Culebra. The tourists can see thousands of orchids on the way from Colon to Panama. by merely looking from the car window at the older trees, many of which are literally covered with these plants.

Part of the contract of the old French Canal Company with the firm that did the preliminary work of building on the Isthmus was the construction of a

Ancon Hos- hospital at Ancon. The side of the hill where pital Gardens. the hospital now stands was terraced for the buildings, and in 1882 a number of Sisters. of St. Vincent were brought to Panama to act as nurses. Their superior was Sister Marie Rouleau, and it happened:

\section{International Pharmacy}

D. FERRUCGIO BERTOLI, M. D.

Wholesale and Retail Drug Store

Perfumery, Toilet Articles, Etc.

Prescriptions Filled

Consultation.at . a11.hours

No. 12, West 12th Street, Panama Gity 


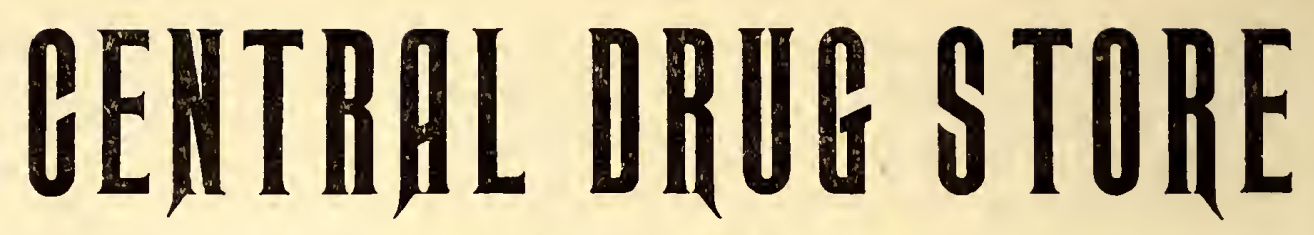
Avenida Central and 10th street, Panama ESTABLISHED 1881

Drugs, Chemicals, Patent Medicines, Perfumeries, etc.

Prescription Department in charge of competent Pharmacists.

Fine Manicure Sets and Toilet Articles

Crisfulina, the great ringworm remedy.

"Remedio Renjifo," effective remedy for rheumatism and blood purifier

SPECIAL AGENT FOR

Newbro's Herpicide

Nialocin Digestive and Laxative Tablets

Iror, Tincture of Athenstaedt

C. N. Disinfectant

Special Agency for ROYAL STANDARD TYPEWRITER

EMANUEL ESPINOSA, B. 
that she was a lover of plants. The garden that now adorns the hospital reservation was begun by her, and has been maintained with more or less care since then. Under the administration of Lieut. Col. G. F. Mason, himself a lover of growing things, the various trees and plants in the gardens have been catalogued. This garden is a microcosm of the plant life of the Isthmus, and anyone who is interested in this phase of Panama should arrange to spend much of his time here. Among the trees and plants classified are the following :

Palms-Wine palm (Acromia sclerocarpo vinifera); palm (Actinorhytis calloparia); Cogolillo palm (Astro caryem polystachium); Sugar palm (Arenga saccharifera); Sago palm (Cycas revoluta); Sago palm (2) Cycas circinalis); Fern palm (Caryotaurens); Panama hat palm (Caruldovica palmata); Porto Rican Royal palm (Oreodoxa Borinquena); Date palm (Phoenix dacty lifera); Fan palm (Prichardii pacifica); Palm Honolulu (Pritchardia gaudichaudi); Curly palm (Kentia belmoreana); Travelers' Tree (Ravenola Madagascariensis); Oil palm (Elaesis melancocca) Corogo Colvolo; Royal palm (Oredoxa regia) Cuba; Royal palm sp. (Oredoxa oleracea); Thatch palm (Thrinax parviflora); Thorny palm (Guiliema utilis) (Pison); Fan palm (Latania Borbonica); Palma real.

Fruits and Nuts-Mamey Bapote (Achras mamosa); Sapodilla (Achras sapota); (Allamanda cathartica); Madrono de Comer (Alibertia edullis); Cashew (Anacardium occidentale); Anacardium rhinocarpus, espave (Anacardicease); Sour sop (Anona muricata); Sugar apple, custard apple (Anona squamosa); Aristotelia macqui) Chili; Custard apple (Anona reticulata Anonaceae); Cocoanut (Cocos nucifera); Jock fruit (Artocarpus integrifolia); Achote, Anatto (Bixa crelana); Coffee (Caffea Zanzabarensis); Palo Maria (Calophyllum calaba); Papaya (Carica papaya); Lime (citrus acida); Sweet orange (Citrus aurantium dulcis); Tangerine (Citrus dancy nobilis); Grapefruit (Citrus decumeana); Lemon (Citrus limonum); Edible fig(Ficus carica); Cluster fig (Ficus sp.); Mangosteen (Garcimia; mangostana); Plantain (Musa Paradiaca); Banana (Musa Sapientium); Avocado (Persea Gratissima); Guava (Paidium guava); Pomgranate (Punica granateum, Myrtaceae); Plum (Spondias edulis); Yellow plum, Hag plum (Spondias lutea) Red plum (Spondias purpurea, Circuelo); Bofug nut (Sterculia foetida, Philippines); Soap berry (Sapindas saponaira); Tamarind (Tamarindus Indica); Chocolate (Theobroma cacao); Vanilla chica (Seleni pedium); - (Anona palustris) not

\section{A TRIP_._PANAMA GANAL}

The Best and Mos: Complete Book of the Canal Ever Published

20 Pages of Reliable Statistics

700 Fine Half Tone Illustrations

From the Early FRENCH DAYS to the PRESENT TIME

ON SALE AT ALL BOOK STORES .. PRI.CE $\$ 3.00$

\section{R. E. AVERY, PUblisher}

724 Perdido Street, New Orleans, La. 


\section{"LA CARAQUENA" S. SHOCRON}

\section{E1 almacen de novedades mejor surtido de Panama}

Las mercaderias existentes en este acreditado almacen

son renovadas constantemente por importantes compras que verifica su proprietario

personalmente en los mas impor-

tautes Centros de la Moda

de los Estados Unidos

y Europa

CONSTANTEMENTE EXPOSICION Y VENTA DE GRANDES SURTIDOS EN

Ropa Exterior para Señolas, Caballeros y Niños, Ropa

Interior para Señoras, Caballeros y Niños, Casimires, Driles, Sedas, Sedalinas, Alpacas Cefiros, Indianas, Zarazas, Encajes, Pasamanerias, Chales, Sombreros, Corbatas, Medias, Perfumeria, Panuelos, Cintas, Peinetas, Adornos para el pelo, etc., etc., etc.

\section{ESPECI ALIDADES EN CALZADO \\ 'ila caliela quifira.}

es el Almacen que vende mas barato

Avenida Central num. 248

P. O Box 19

Telefono num. 171

PANAMA (R. de P.) 
edible; Marking nut (Semecarpus anacardium); Kafir orange (Strychnos spinosa, Africa); Mamey (Mamea Americana, Guttiferae); Guava real (Inga spectabilis) Macaws (Guadopalin, Diphisa robinioidies); Yam (Dioscorea alata); Kafir plum (Harpephyllum caffrum); Mango (Mangifera Indica, Anacardiaceae); Klat, Arabia (Catha deulis); Medicine nut (Jatropha curas, Euphorbiceae).

Miscellaneous Trees, Plants and Roots-Rubber tree (Ficus elasticus); Indian rubber tree (Ficus Indica); Para rubber (Hevea, sp.); - - (Eucalyptus botryoides); Silk oak, - (Grevillea robusta); Guacimo (Guazuma ulmifolia); Cola (Cola acumuiata); Japanese bamboo (Bambusa argentea); —. (Bambus arundinacea); Bastard teak (Butea frondosa); Ornamental ash (Phoeni xreclinata); Rain tree (Pitheccolobeum saman); Umbrella tree, Japanese varnish (Steraulia platonifolia); —— (Yucca elephantipes); Mahogany (Swietonia mahogani) Teak wood (Tectona grandos); - (Pamdanus veitchii); Cassava (Manihot aipi, Euphorbiceae); Calabash (Cresentia cujete); Arrow root (Maranta arundinacea); Crow tree (Hermesias grandicips); Sandbox (Huracrepitans Euphorbiceae); Native rubber (Castilla panamensis); Camphora; Snake wood (Cecropia palmata); Job's tears (Coix lacrymo Jobi); Jamaican Elder (Cedrela odorata); Soap berry (Sapindus saponaria); Ciruelo chino (Spondias dulcis, Anacardioceae); Dragon tree (Dracaena lindeni); Grape tree (Coccoloba, uvifera); - (Ficus altissima, urticaeae); Bread fruit (Artocarpus incisa, urticaeae); Snake wood (Cocropis palmata, urticaeae); Marango (Moringa oleifera); Algaroba (Hymenea courbaril).

Flowering Bushes and Plants-Sapote (Lucuma Mammosa, Sapotaceae); India Kale, Calocesias atrovikus (Xanthosoma); Spanish lily (Crinum evubesceur); Kirkie (Cavanillesis platanifolia, Stereubiaceae); - (Corozo galleraze, Attalia gomphoese); Australian pine (Casurarina, squisedifolia); - (Achras Ingesto, Pittier); - (Xanthosoma violaceum); Tree fern (Polypodium); Screw pine (Pandamus utilis); - - (Chlorphora tinctoria, Madusa Fustie); - _- (Acalpha Mosiaca, Euphordicaeae); Poroporo (Cochlospermum hibiscodes); Fustie (Chlorophora tinctoria, Machura tinctoria); Sterculiaeae (Chlorophora tinctoria, Machura tinctoria); Sterculiaeae (Cavanillesia plantanifolia); - (Calophyllum kunsterli longifolium); Bala (Gliricidia maculata); Bougainvillea (Glabra Sanderiana) - (Garcinia Xanthochyma); Gamboge (Garcinia morella); Cape jessamine (Gardenia Florida); "Jagua" (Genipa carute); Cacho de venado (Gilibertia arborea); - (Gynandropsis pentandra); Membrilla (Gustavia augustifolia); Corteza (Arabia guilfoylei); - (Aralia); Cerizo (Bunchosia glauea); Nance (Byreonima crassifolia); Cana fistala (Cassia leiantha); Mazano-Salamo (Calycophyllum candidissium); Otaheita gooseberry (Cicca disticha); (Pito Erythrina corallodendron); Pavilla (Didymopanax morototoni); Ameryllis lily (Hippeastrum equestre);-_- (Hibiscus rosa); Ginger lily (Hedychium coronarium); Yellow morning glory (Ipomoea tuba rosa); —— (Ixora sp.);-—— (Jasminum gracilli-

\section{FRENCH DRUG STORE DELGADO \& SALAZAR}

Front St., No. 37, Opposite R. R. Station, Colon

\section{Leading Drug Store in the City of Colon All kinds of Perfumes in stock}


JOSEPH M. 0'BRIEN DANIEL J. DEMPSEY
IOHN H: SCHLENZ CHARLES W. WRIGHT

\section{Central American}

Plumbing \& Supply Co. COLON - - PANAMA 'PHONE 249

P. O. Box 108

P. O. Box 223

Plumbing in all its branches

WE OPERATE THE LARGEST AND MOST COMPLETELY STOGKED ESTABLISHMENTS IN GENTRAL AMERICA

Estimates furnished on contract work to any extent

Contractors for Panama National Institute, University Club, Etc.

COLON

66 BOLIVAR STREET
PANAMA

SANTA ANA PLAZA 
mum); Spanish jessamine (Jasminum grandiflorum); Hardy jessamine (Jasminum officianale);- (Guacimo colorado, Tilaceae);-_Luhea rufescens); Crepe myrtle (La1gerstroemia Indica); Langsat, Java (Lansium domesticum); Anacimo blanco (Luebea sp.); - (Tabernaemontana coronaria); Red croton (Xanthosoma sp.); Malagueto grande (Xylopia grandiflora); —- (Xanthosoma violaceum); (Indica kali-coloceasia); Agati (Sesbania grandiflora); Panama (Sterculia carthargensis); - (Plumbago capensis); - (Pentaclethana); Job de Iguana (Phylanthus sp. euphorbiceae); Lace plant (Pilea urticaeae); Cola (Cola acuminalta); Rose apple, myrthaceae (Eugenia jambos); —— (Biguonia); (Erythrina sp.); Sangvillo (Croton panamensis); Poinsettia (Euphorbia pulcherrima); - (Pachira Barrigon); - (Panax excelsium); Spanish lily, white (Pancratium ovatum); - (Pachira macrocarpa); La Viuda (Petrosa volubilis verbenaceae); - (Feijoa selloniana, Brazil); - - (Panax plumatum); Frangi-pani (plumeria); Cun de Amor (Momordica charantia); Acacia Farnesiana (Flor de Aroma); Century plant (Agave Americana); Coral vine (Antigonon leptopus', Cadena de Amor, Bellissemia); Laurel (Cordia gerascanthus); Coleus; Cola (Cola Acumniata); Crotons (Codieaum variegatum); Cabbage tree (Andiva inermis); Cope Grand (Clusea rosea); Calladium; Canna; Rose apple, Hawaii (Caryophylus malaccensis); - (Clerodendron Balfouri); Pigeon pea (Caianus Indicus); Dwarf poinciana, Gallito (Caeaslpunia pulcherrima); Furcraea; Pink (Garcinia Livingstonei); Royal poinciana (Delouix regia); Surninam cherry (Eugenia uniflora, myrthaceae); Loquat (Eriobotystia japonica); Fern sp. (Glichenia); Moon flower (Iponica bona nox); Sweet William (Ipomoea quamoclit); Henna (Lawsonia alba); Sensitive plant); (Mimosa pudica); Four O'clock (Mirabilis jalapa); Oleander (Nerium); Spider lily, white (Pancreatium ovatum sp.); Maria (Thespesia populea); - (Tradescantia discolor); - (Vinca rosea); - (Zingiber officinale); Wandering Jew (Zabrina pendula); Chenille plant (Acalypha sanderi); Cado de venado (Gilbertia arborea); - _- (Jatropha aconitfolia); Snowflake, var. Rosea picta (Phallanthus nervoeus, Euphorbiceae); Biviba (Rollinia orthopotala, Brazil); Flamboyant Blaues (Bauhinia purpurea, Leguminosoe); Corteza (Apeiba Tobourou, Tiliaceae); - - (Phyllanthus emblica, euphorbiceae); - (Phyllanthus acuminatus, euphorbiceae); (Duranta plumieri, verbenaceae); - (Cuscuta, convolulacoe); Corotu (Entero-
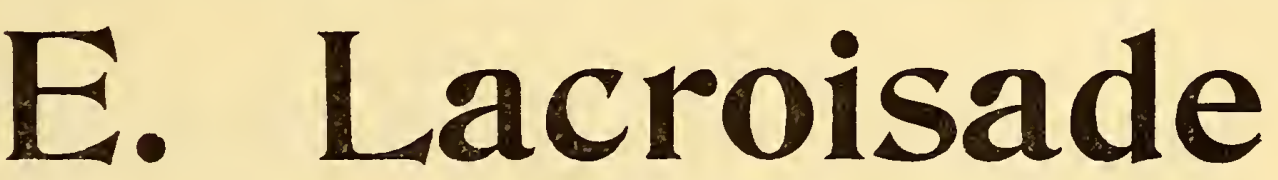
Jeweler and Watchmaker

OptTICAL, GOODS

No. 77 CENTRAL AVENUE $-\quad-\quad-\quad-\quad$ PANAMA
-AGENT FOR-

Underwood Typewriter, "Longines" Swiss Watches

\section{Direct Importer from Europe and United States}




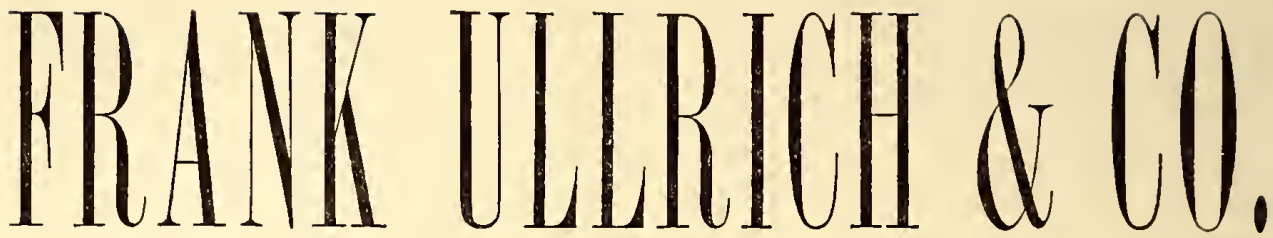

COLON AND PANAMA

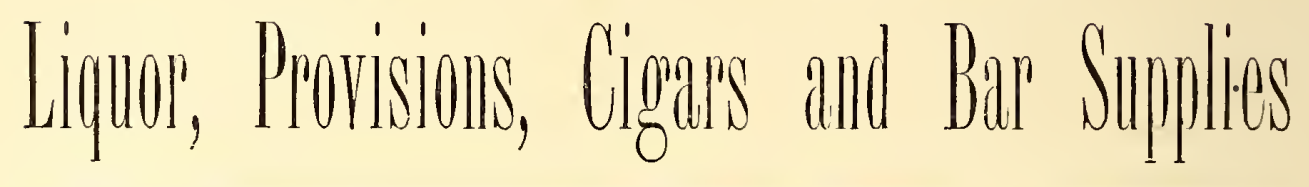

REPRESENTATIVES OF

Anheuser Bush Brewing Assn., St. Louis: Botlled Beer. Washburn Crosby Co., Minneapolis: Gold Medal Flour. Park \& Tilford, New York: Chocolate and Bon Bons. Cresca Co., New York and Bordeaux: Conserves etc. White Rock, King of table waters, Still and charged. St. Charles Condensing Co., St. Charles, I1l.: Evaporated Milk.

Oakdale Mfg. Co., Providence, R. I.: Oleomargarine West Disinfecting Co., New York: Disinfeccants and Appliances.

Lever Bros. Ltd., Port Sunlight: Soaps.

Dr. J. G. B. Siegert, Trinidad: Angostura Bitters.

Hiram Walker \& Sons: Canadian Club Whiskey.

Wm. Lanaham \& Sons: Hunter Rye Whiskey.

Wilson Distilling Co.: Wilson Rye Whiskey.

Distillers Co., Ltd., Edinburgh: D. C. L. Whiskey and Old Tom.

Moet \& Chandon: White Seal Champagne.

Martini \& Rossie, Torino: Vermouth.

Bernese Alps Milk Co., Stalden, Swiczerland: Milk.

\section{AGENTS OF ... \\ BARTLING, de LEON \& CO.,}

24 STATE STREET, NEW YORK. 
lobium cyclocarpym);

(Philodendrom); Coruntia pyramilata (Palo cuadrodo); Dancy (Cytharexylum candatum, verbenaceae); Leaf of Life, Leaf of the Air (Bryophyllum calycinum, crassalaceae);

(Foijoa sellowiana, Brazil); - (Pachira Barrigon); China berry (Melia Azedarach); - (Murrya exotica); (Myroxylon); Dragon's eye, China (Nephelium longana);

(Piper cordoncilla); - (Phyllanthus acuminatus); - (Pentoclethra); (Ordinancia); - (Ocotea); - (Rheo bicolor); (Rhinacanthus nasutus); Biniba (Rollimis orthopotala, Brazil); - (Schizolobium excelsium); (sapium Moritzium); - (Strychnos nux vomica); - (Thevetia nitida); - (Thrichilia); - (Vismia panamensis); — (Vinca rosea); - - (Vernonia); Red Croton (Xanthoseoma sp.); Malagueto grande (Xylopia grandiflora); Star apple (Phrysophillum Cainito); Grendilla (Passiflore quadrangularis); Fabaceae, East Indies (Agati grandiflora); Four winged bean, Saguidillas (Botor tetragonoloba, Fabaceae); Calladium colocasia, Taro (Colocasis esculentum, Araceae); (Didymopanax morototoni); Pito (Erythrina colallodendron); Rubiaceae, native (Hamelia patens); (Lantana camara, Verbenaceae);

(Philodendron, Aroideae); Tube rose (Polianthes pancratium tuberosa, Lilliaceae); (Thevetia nerifolia, A pocyneae); Indian kale (Xanthosoma atrovirens, Araceae); Zepher lily (Zephyranthes, a maryllis rosea, Lilliaceae); Psidium guave, myrthaceae.

The Weather and Related Meteorological Subjects.

Panama weather may be described as very warm during day and cool at night. It is never "hot" here in the sense that it is in New York, Montreal, and Dawson City, in the middle of summer. On the other hand, it is never "cold" in any sense. At night one must frequently resort to a light cotton blanket to keep him from awakening in the morning with his head filled up with a cold; and in the early morning while the fog yet hangs over Culebra Cut it is often so chilly as to make a woolen coat quite comfortable. In the hours between $9 \mathrm{a} . \mathrm{m}$. and $5 \mathrm{p}$. $\mathrm{m}$. it is so warm

\section{Panama Banking Company \\ (American Charter) Panama and Colon}

\section{Drafts and Cable Transfers on the Principal Cities of the World}

GENERAL BANKING BUSINESS

Isaac Brandon, $\begin{gathered}\text { President }, \\ \text { Prenarice, }\end{gathered}$




\section{Isage Prandone. Bpros., InC.}

--: Pan a n a :-

Incorporated under the Laws of the State of New Jersey, U.S.A.

Capital Stock = $\$ 750,000$, U. S. C.

\section{General Merchants}

$$
\text { SUB-AGENTS OF }
$$

The Royal Mail Sieam Packet Co.,

Scottish Union \& National Insurance Co. of London and Edinburg

Funds \& 6,000,000 Sterling

Guardian Assurance Co., Ltd. of London, Funds exceed \& 5,250,000, Sterling REPRESENTATIVES OF

W. \& A. GILBEY, LTD., LONOON-Wines and Spirits JAMES HENNESSV \& CU.-Cognac

HENRI NESTLE-Condensed Milk

B. \& J.B. MA CHADO,JAMAICA-Cigars "La rropical" NESTOR GIA.NACLIS-Egyptian Cigarettes

PEEK, FREAN \& CO., LTD., LONUON-Fine Biscuits LANMAN \& KEMP, NEW YORK-Florida Water

J. \& J. COLMAN, LTD., LONDON-Blue, Mustard, erc. RUBT. PORTER \& CO., LTD., LONDON-Bull Iog Brand Guinness' Stout and Bass' Ale

THE WILLIAM J. LEMP CO., ST. LOUIS-Bottled Beer

BARTON \& GUESTIER, BORDEAUX-Clarets and Write Wines

PHILIP W. HEY.MAN, COHENHAGEN-Fine Danish Butter

AUǴUSTINER BRAU-Celebrated Munich Beer

\section{AGENTS OF}

Isaac Brandon \& Bros., Inc.,

17 BATTERY PLACE, NEW YORK,

Commission Merchants 
as to make any coat uncomfortable in the sun. Women wear summer clothing all the year around in Panama, but few of the men do, largely because they are so conservative that they will not change from the "States" clothing for fear of being suspected of dandyism. Men haven't much sense anyhow.

A heavy wind springs up about the middle of each December, blowing across the Isthmus from north to south.

It is called the trade wind. It continues

Dry Season. to blow until about May 1. While this wind is blowing, the clouds that otherwise would have formed over the Isthmus are carried away, and therefore there is no rain. Now and again the wind will cease long enough for a rain to form. The average rainfall for the months of January to May, for forty years of record at Cristobal, is 11.47 inches; at Ancon for 13 years, 5.24 inches; at Culebra for 20 years, 7.01 inches. This is the season that corresponds to winter in the United States, for it is then that such plants as die each year are withered up, and the trees drop their leaves. It is like the northern summer in that the fruits and flowers are most profuse at this time.

The rainy season occupies the eight months of the year not taken up by the dry season. The average rainfall in the wet-season months, May to December Rainy Season. inclusive, at Ancon during a period of 13 years, has been 66.43 inches; Culebra, 20 years of record, 83.94 inches; Cristobal, 40 years, 118.56 inches; Porto Bello, 3 years, 149.20 inches. This is a large quantity of rain. There are few days in those eight months when there is not at least one shower, and this usually occurs between 12 o'clock noon and 2 p. $\mathrm{m}$. Sometimes it rains all day, at other times there are short showers lasting only a few minutes. It has rained three-fourths of an inch in five minutes, 5.86 inches in one hour, 10.86 inches in 24 hours, since the American occupation, and these maximum records are typical of many other heavy storms. The sudden downpours flood the streams; the Chagres River, a placid little stream before the lake was formed, would fill to its banks, of ten overrunning the surrounding fields; and sometimes railroad traffic was interfered with when the old main line through the river bottom was in use. The rains are not accompanied by heavy winds, and, therefore, no damage to crops is done, and, except in cases of very. severe storms 


\section{"LA ULTIMA MODA" \\ P. ODUBER \& Co. \\ CORNER 8TH AND SOSSA STREETS, PANAMA CITY}

\section{THE ONLY STORE IN PANAMA DEVOTED SOLELY TO LADIES' ARTICLES ........}

Best French,

\section{Fnglish and \\ American Goods}

The favorite Store among the American Ladies of the Isthmus.

While in Panama do not fail to call at THE LADIES' STORE

LOCAL 'PHONE 316, PANAMA 
the Canal workers do not stop because of the showers. The average annual rainfall for years of record at typical stations is. shown in the following table:

\begin{tabular}{|c|c|c|c|}
\hline & Years & Inches. & Location. \\
\hline Ancon. & 13 & 71.67 & Pacific coast. \\
\hline Culebra & 20 & 90.95 & Summit cordillera. \\
\hline Gamboa & 28 & 93.79 & Middle Chagres Valley \\
\hline Alhajuela & 11 & 107.14 & Upper Chagres Valley \\
\hline Gatun... . & 6 & 140.55 & Lower Chagres Valley \\
\hline Cristobal... & 40 & 130.03 & Atlantic Coast. \\
\hline Porto Bello. & 3 & 178.67 & Atlantic Coast \\
\hline
\end{tabular}

Temperature. The temperature is fairly even, and the humidity is always high. The maximum and minimum of recent years in three sections are shown in the following statement:

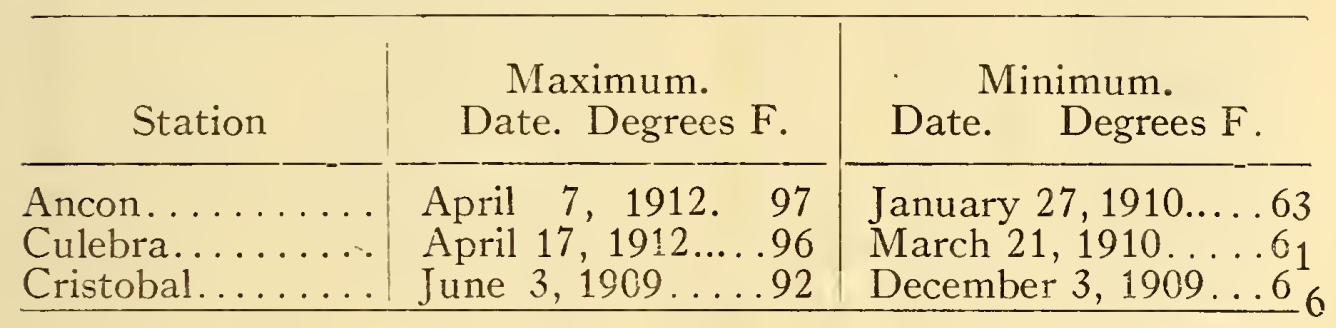

The termperature of sea water on the surface on the Atlantic side of the isthmus is, average, 81 degrees F.; lowest, 75 degrees F.; Pacific side, average, 80 degrees F.; lowest, 60 degrees $\mathrm{F}$.

The evaporation was highest in 1908, when the record

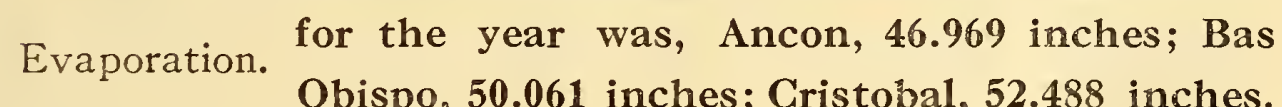

The fogs come about 2 o'clock in the morning and are dissipated by the sun before 8 o'clock. There is no sight on the canal more impressive than Culebra

Fogs. Gut during a heavy fog. While it is still dark one may hear the puffing of the work locomotives down in the trench, the clang of iron on iron, the chug-chug of the drills, and catch a gleam occasionally of the light of a locomotive piercing the veil of mist. Work is in full swing at one minute after seven every week-day morning, and from the banks the watcher may see the mist roll away, gradually revealing the broad cut, each minute giving 
ADVERTISEMENTS.

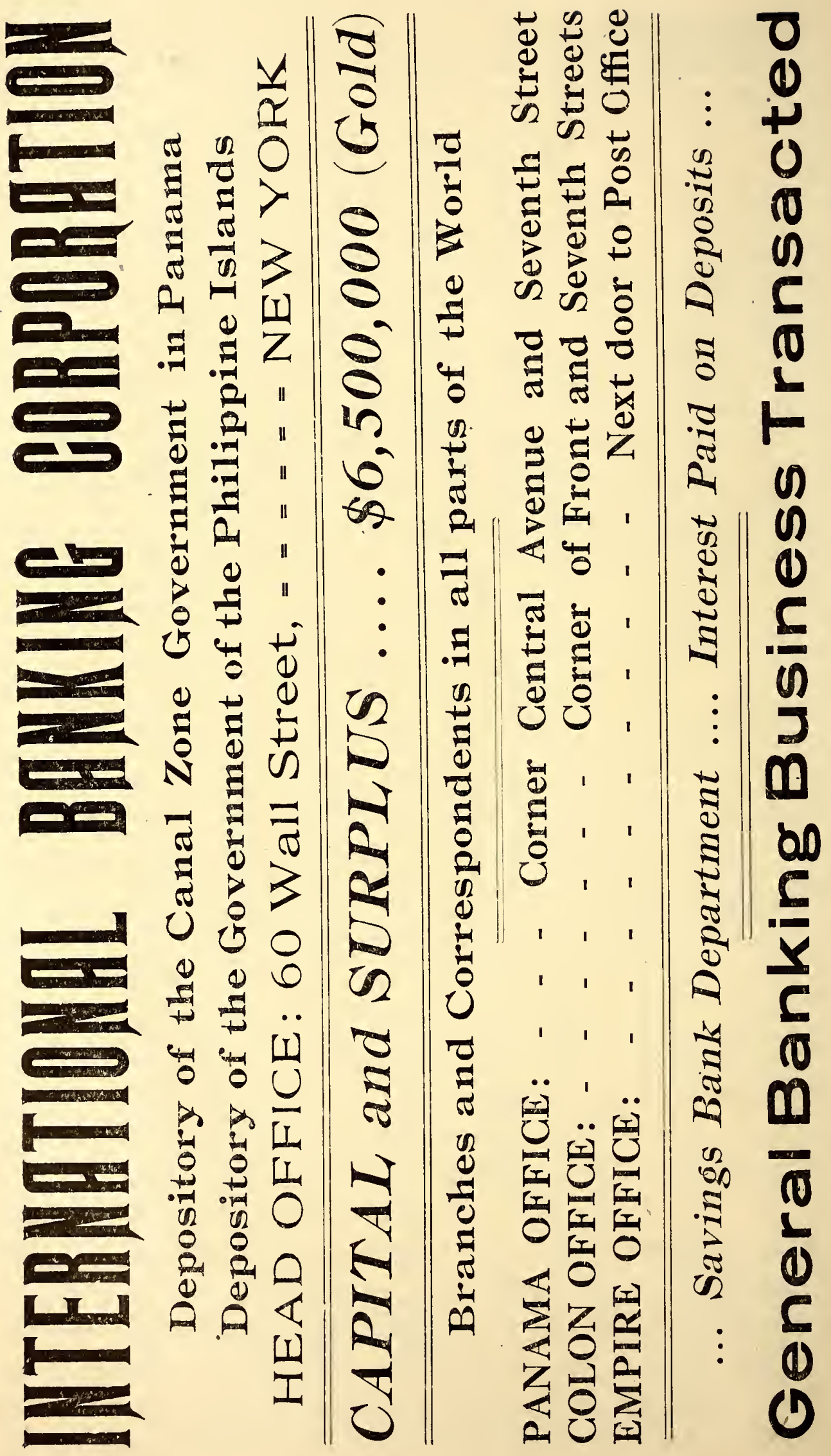


some new cynosure of industry. A typical year for fogs was 1910, when there were 197 foggy nights at Culebra. the average duration being 5 hours 37 minutes; 8 fogs at Ancon, average duration, 2 hours 38 minutes; 6 at Cristobal, average, 4 hours 12 minutes; 217 at Bohio, average, 5 hours 35 minutes.

The maximum range of the tide at Balboa, the Pacific entrance to the Canal, is 20.8 feet; that is, the difference between extreme low and extreme high tide

Tides. in one oscillation, is 20.8 feet. The minimum is 5.1 feet. At Cristobal the maximum is 2.17 feet, and of ten there is no difference between the low and the mean so that no minimum can be given.

Several times in its history the Isthmus has been shaken by earthquakes, the most serious being that of 1882 , referred to on page 126. None of these disturbances Earthquakes. has been so serious as to affect the working of the machinery in the locks of the present canal or the tidal locks of a sea-level canal. Each year the Isthmian Canal Commission publishes its record of seismic disturbances; and correct reports may thus be obtained.

Winds.

The maximum velocity of the wind at Ancon in 1910, a typical year, was 31 miles an hour, average, 7.3 miles; Culebra, 39 miles, average, 6.9; Cristobal, maximum, 38, average, 9.8 .

\section{Latitude and Longitude.}

The latitude and longitude of three main points on the isthmus are as follows:

\begin{tabular}{|c|c|c|}
\hline Point. & Latitude $\mathrm{N}$. & $\begin{array}{l}\text { Longitude W, } \\
\text { Greenwich. }\end{array}$ \\
\hline $\begin{array}{l}\text { Colon Lighthouse... } \\
\text { Cerro Gigante (Gor- } \\
\text { gona) ........... } \\
\text { Panama Cathedral } \\
\text { S. E. Spire....... }\end{array}$ & $\begin{array}{l}9 \text { d. } 21 \mathrm{mi} .55 .314 \mathrm{~s} . \\
9 \text { d. } 4 \text { m. } 57.637 \mathrm{~s} . \\
8 \text { d. } 57 \text { m. } 13.676 \mathrm{~s} .\end{array}$ & $\begin{array}{l}79 \text { d. } 54 \text { m. } 38.811 \mathrm{~s} \\
79 \text { d. } 43 \text { m. } 50.313 \mathrm{~s} . \\
79 \text { d. } 32 \text { m. } 16.516 \mathrm{~s} .\end{array}$ \\
\hline
\end{tabular}

Postage Rates.

The rates for postage printed herewith apply alike to. Panama and the Canal Zone: 


\section{WHEN IN PANAMA}

VISIT

\section{IIISTELI THE JEWELER}

Pearls, Diamonds, Jewelry, Watches,

Silverware, Clocks, Bronzes and

Artistic Merchandise

"Souvenirs"

SOLE AGENTS ON THE ISTHMUS FOR:

Reed \& Barton, American Silverware

Meriden Cut Glass Co.

Patek Philippe \& Co., Swiss Geneva Watches

Louis Brandt $E$ frère, Omega $W$ atches

.SOLE OFFICIAL AGENT FOR ADVERTISEMENTS IN THE CITY .

Misteli, the Jeweler, has the best collection of Old Indian Jewelry.

$$
\begin{aligned}
& \text { - For SOUVENIRS - - } \\
& \text { See Misteli the Jeweler. }
\end{aligned}
$$

For Old Jewelry, see Misteli the Jeweler.

For Pearls and Diamonds, see Misteli the Jeweler.

Optical Goods, Watches and Jewelry, repaired.

For Silverware and Cutglass, see Misteli the Jeweler

For Swiss and American Watches, see Misteli the Jeweler. 


\section{Domestic.}

First Class-Letters and sealed matter, 2 cents for each ounce or each fraction. Postal cards and post cards, 1 cent each.

Second Class-Newspapers and periodicals, 1 cent for each four ounces or fraction thereof.

Third Class-Miscellaneous printed matter, 1 cent for each two unces or fraction thereof.

Fourth Class-All matter not included in first three classes, 1 cent for each ounce or fraction thereof.

Domestic rates apply to all mail for Panama, the United States, Canada, Cuba, Guam, Hawaii, Mexico, Philippines, Porto Rico, Tutuila.

\section{Foreign.}

Letters and Sealed Matter - 5 cents for the first ounce and 3 cents for each additional ounce or fraction thereof.

Post Cards - 2 cents each.

Commercial Papers - 1 cent for each two ounces or fraction, but not less than 5 cents on each packet.

Printed Matter-1 cent for each two ounces or fraction.

Samples of Merchandise-1 cent for each two ounces or fraction, but not less than 2 cents for each packet.

Parcels Post-12 cents per pound. Thanks to the union between the express companies and the country stores, this rate is not available on matter sent to the United States.

\section{'Customs Regulations.}

\section{A summary of the principal customs regulations apply- ing to Americans returning to the United States, para- graph 709, appearing in the free list of the present tariff act governing passengers' baggage, reads as follows:}

Wearing apparel, articles of personal adornment, toilet articles, similar personal effects of persons arriving in the United States free; but this exemption shall only include such articles as actually accompany, and are in the use of, and as are necessary and appropriate for the wear and use of such persons, for the immediate purposes of the journey and present comfort and convenience, and shall not be held to apply to merchandise or articles intended for other persons or for sale: Provided, That in case of residents of the United States returning from abroad, all wearing apparel and other personal effects taken by them out of the United States to foreign countries, shall be admitted free of duty, without regard to their value, upon their identity being established, under appropriate rules and regulations to be prescribed by the Secretary of the Treasury, but not more than one hundred dollars in value of articles purchased abroad by such residents of the United States shall be admitted free of duty upon their return.

Residents of the United States must declare all articles which have been obtained abroad by purchase or otherwise, whether used or unused, and whether on their persons, in their clothing, or in their baggage. The foreign value of each article, stated in United States money, must also be declared.

Articles taken from the United States and remodeled, repaired, or improved abroad must be declared, and the cost of such remodeling, repairing, or improving, must be separately stated 


\section{Emanuel Lyons}

Panama's 0ldest Hardware Store (ESTABLISHED 1868)

78-80, and 338-40, CENTRAL AVENUE, PANAMA CITY . . BETWEEN 8th and 9th STREETS

Leaders at Start AND Leaders Today

Largest Assortment in the Country

Most connmodious establish. ment of its kind AGENT OF

The Jamaica Mutual Life - Assurance Society . of Kingston, Jamaica, B. W. I. 
The following articles are dutiable: Household effects, including books, pictures, furniture, tableware, table-linen, bed-linen, and other similar articles, unless used abroad by the owner for a period of a year or more. Goods in the piece. Articles of any nature intended for sale, or for other persons.

The following articles are free if under $\$ 100$ in value, and if necessary for comfort and convenience for the purposes of the journey, and not for sale nor for other persons: Clothing; toilet articles, such as combs, brushes, soaps, cosmetics, shaving and manicure sets, etc.; personal adornments, jewelry, etc.; similar personal effects, which may include cameras, canes, fishing tackle, glasses (field, opera, marine), golf sticks, guns, musical instruments, parasols, photographs, smoker's articles, steamer rugs and shawls, toys, trunks. valises, etc.; clothing and other personal effects taken out of the United States by the passenger if not increased in value or improved in condition while abroad. If increased in value or improved in condition, they are dutiable on the cost of the repairs.

The above list of articles, which are dutiable and nondutiable, are stated for the assistance of passengers, and are not exhaustive. $A l l$ articles are dutiable unless specifically exempted by law.

Pack in one trunk if practicable, all dutiable articles.

Receipted bills for foreign purchases should be presented whenever possible.

Use does not exempt from duty wearing apparel or other articles obtained abroad; but such articles will be appraised at their value in the condition as imported, due allowance being made for depreciation through wear and use.

Nonresidents of the United States are entitled to bring in free of duty without regard to the one hundred-dollar exemption, such articles as are in the nature of wearing apparel, articles of personal adornment, toilet articles, and similar personal effects, necessary and appropriate for their wear and use for the purposes of the journey and present comfort and convenience, and which are not intended for other persons or for sale.

Citizens of the United States, or persons who have at any time resided in this country, shall be deemed to be residents of the United States, unless they shall have abandoned their residence in this country and acquired an actual bona-fide residence in a foreign country.

Such citizens or former residents who desire the privileges granted by law to nonresidents must show to the satisfaction of the collector's representative on the pier, subject to the collector's approval, that they have given up their residence in the United States and that they have become bona fide residents of a foreign country.

The residence of a wife follows that of the husband; and the residence of a minor child follows that of its parents.

Household effects of persons or families from foreign countries wil be admitted free of duty only if actually used abroad by them not less than one year, and if not intended for any other person, nor for sale. Such effects should be declared whether the passenger be a resident or a non resident of the United States.

Articles intended for use in business, or for other persons, theatrical apparel, properties, and sceneries, must be declared by passengers, whether residents or nonresidents. 


\section{Lh}
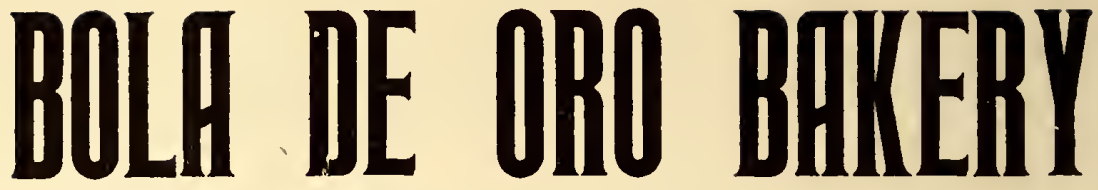

This is the oldest Establishment of its class in Panama

SKILL AND CLEANLINESS

in the making of Bread and Biscuits

DELIVERY AT MOMES

FLOUR BY WHOLESALE AND RETAIL

Orders from the Interior of the Republic and from the Canal Zone given prompt attention

$\begin{array}{ll}\text { EAST 13TH ST., PANAMA CITY P. O. BOX } 77 & \end{array}$ TELEPHONE 384

BALBINO GARCIA, Proprietor

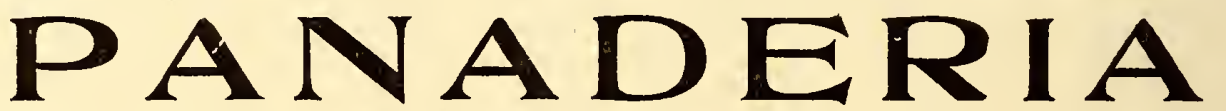

Es el establecimíento más ántigo en su clase en Panamá. Esmero y limpieza en la eiavoración de Pan y Galletas.

Servicio á Domicilio

Se vende Harina al por mayor y el detalle

Las ordenes del interior de la República y Zona del Canal se atienden con puntualidad

Calle 13 Este, Panama City, apartado de Correos 77 Telefono 384

Balbino Garcia PROPIETARIO 
All cigars and cigarettes must be declared. Each passenger over eighteen years of age may bring in free of duty 50 cigars or 300 cigarettes if for the bona fide use of such passenger. Such cigars and cigarettes will be in addition to the articles included within the $\$ 100$ exemption.

The law provides that every person entering the United States shall make a declaration and entry of his or her personal baggage, The law further requires that the values of articles shall be determined by customs officers, irrespective of the statements of passen gers relative thereto.

It will thus be seen that there is no discourtesy in the requirement that both a declaration and an independent appraisal shall be made. Taken together, these requirements place the passenger in the same position as any other importer of merchandise.

Passengers should observe that on the sheet given them there are two forms of declarations (the one printed in black is for residents of the United States) the one in red, for nonresidents.

The exact number of pieces of baggage, including all trunks, valises, boxes, packages, and hand bags of any description accompanying the passenger, must be stated in the declaration.

The senior member of a family present as a passenger, may make declaration for the entire family.

Ladies traveling alone should state that fact in their declarations, in order that an expeditious examination of their baggage may be made.

\section{PANAMA PRESSING CLUB}

\section{THE MONTECRISTI}

PANAMA HAT STORE $\mathrm{OF}$

\section{Arroyo Tobalina \& Co.}

\section{GENUINE PANAMA MATS}

FOR

Ladies, Gentlemen and Children ALL KINDS OF HATS

Especially FELTS and JIP JAP (Panama)

CLEANED, FITTED OR REPAIRED IN ONE HOUR

Situated in same Building occupied by

THE PANAMA PRESSING CLUB

140 Central Avenue. P. 0. Box 130. Telephone No. 30 
When the declaration is prepared and signed, the coupon at the bottom of the form must be detached and retained by the passenger and the form given to the officer of the ship designated to receive the same. A declaration spoiled in its preparation must not be destroyed, but turned over to the purser, who will furnish a new blank to the passenger.

After all the baggage and effects of the passenger have been landed upon the pier, the coupon which has been retained by the passenger must be presented at the inspector's desk, whereupon an inspector will be detailed to examine the baggage. Passengers must acknowledge in person, on the pier, their signature to their decla rations.

Examination of any baggage may be postponed if the passenger requests the officer taking his declaration to have it sent to the appraiser's store.

Passengers must not deduct the $\$ 100$ exemption in making out their declarations. Such deductions will be made by customs officers on the pier.

Passengers dissatisfied with values placed upon dutiable articles by the customs officer on the pier may demand a reexamination. but application therefor should be immediately made to the officers there in charge. If for any reason this course is impracticable, the packages containing the articles should be left in customs custody and application for reappraisement made to the collector of customs, in writing, within ten days after the original appraisement. No request for reappraisement can be entertained after the articles have been removed from customs custody.

PENALTY FOR NOT DECLARING ARTICLES OBTAINED ABROAD.

Under Sections 2802 and 3082 of the Revised Statutes of the

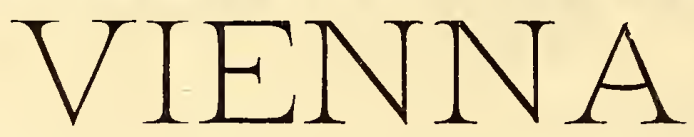

Pastry, Cakes, Ice Cream and Refresh ments Saloon

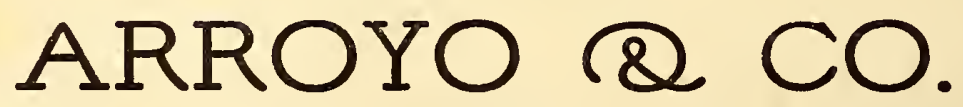

Specialty in Bouquets, Creams and Appetisers

OUR PRICES ARE EXCEEDINGLY LOW

Orders by Telephone will be served at DELIVERY

TELPHONE 1O-B. P. O. $B O \times 130$

CENTRAL AVENUE No. 225

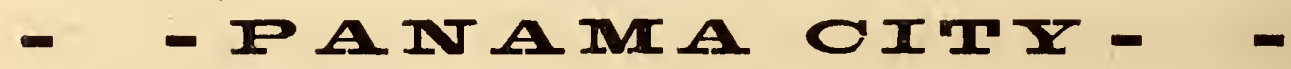


United States, articles obtained abroad and not deslared are subject to seizure, and the passenger is liable to criminal prosecution.

\section{The Stars.}

It is presumed that only those who know the principal stars and constellations visible in the north temperate zone will take a definite interest in the stars of the tropics, althoug $h$ anyone who looks upward at night must be impressed by the great brilliancy of all the stars, standing out as they do as sharply as on the clearest winter nights north of the tropic of cancer. The star scope in Panama reaches from Polaris in ursa minor, which is low on the northern horizon, to Argo Navis (the ship of the argonauts) which stretches across the southern sky.

In the book by Garrett P. Serviss, "Astronomy with the Naked Eye" (Harpers, New York, 1908) there is a delightfully written chapter on the Southern Constellations, and the facts here cited are on the authority of that chapter, as the star chart herewith is an abridgenemt of the chart in Serviss' book.

As in the north, the stars in Panama are at their best in winter time, when there is least moisture in the air. Then appear the bright constellations Orion, Casseopeia, Ursa Major, Canis Major, Auriga, Taurus, Argo Navis, Crux, and Centauri. Only the last three are peculiar to the tropics. They are visible from January to September, but are best seen from March to September when all are visible at some time between sunset and ten o'clock. When Orion is about 45 degrees
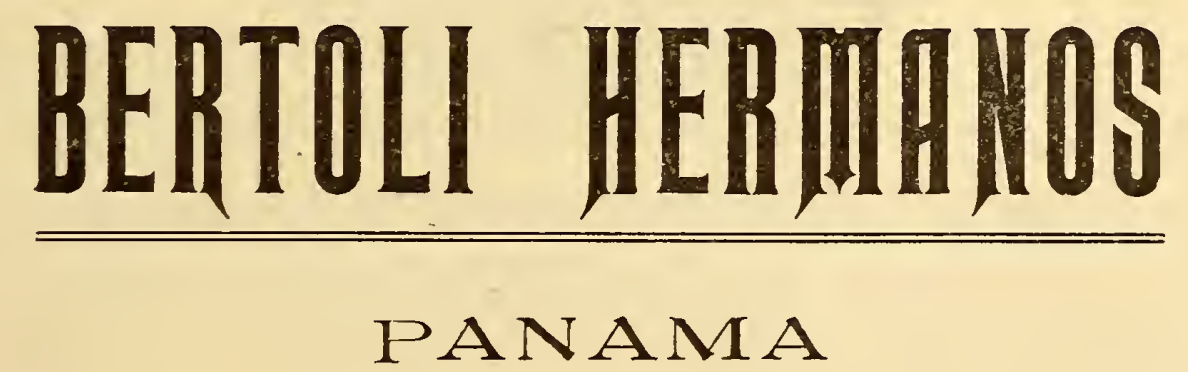

WHOLESALE IMPORTERS OF

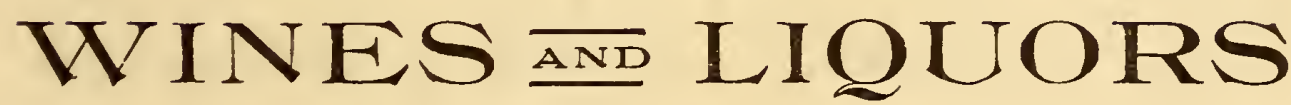


above the western horizon, March 1 to 20, the Sou thern Cross is just rising above the eastern horizon, and an hour later the bright stars of the Centaur appear.

Stars between the inner circles can be seen from Panama, but not from States of the United States, north of latitude $35^{\circ}$. No stars are shown within the inner circle because they are not visible from Panama. Stars observable from north of $35^{\circ} \mathrm{N}$. are shown in order that one may locate the southern stars. (1) is Orion with its bright star "Rigel"; (2) Canis Major with Sirius; (3) Argo Navis with Canopus and its second bright star "Eta"; (4) Crux or Southern Cross; (5) Centaurus with its bright stars "Alpha" and "Beta"; (6) Hydra, or Sea Serpent; (7) Corvus, the Crow; (8) Virgo with its bright star "Spica"; (9) Ara, the Altar; (10) Libra; (11) Scorpio with its bright star "Antares"; (12) Capri-

\section{Panama HardWare Comnan}

CATHEDRAL PLAZA, PANAMA

A more varied assortment of

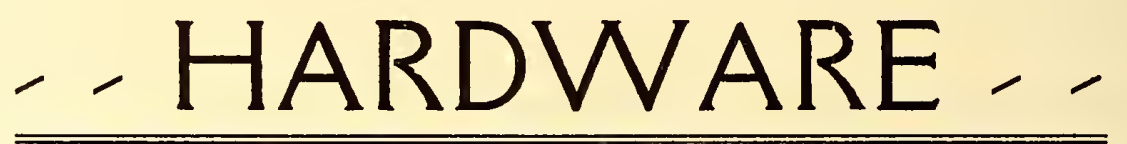

than any other establishment in the country. Arms, Ammunition, Electrical Materials Kodaks and Photographic Supplies Saddles and Veterinary Remedies OPEN ON SUNDAY - 8 TO 11 A. M

\section{ERIC BARHAM \& CO}


cornus; (13) Grus, the Crane; (14) Pisces Aus, Southern Fish; (15) Toucan; (16) Phoenix; (17) Eridanus with the bright star "Achernar." Dotted lines show direction of Milky Way. Argo Navis, the ship of the Argonauts, in which Jason and his followers set out to search for the golden fleece, stretches clear across the southern sky, its Argo Navis. northernmost stars mingling with those of Canopus. Canis Major, while on the east it almost touches Centaurus and the Southern Gross. Its bright stars outline well the hull of a ship, remarkably like a modern

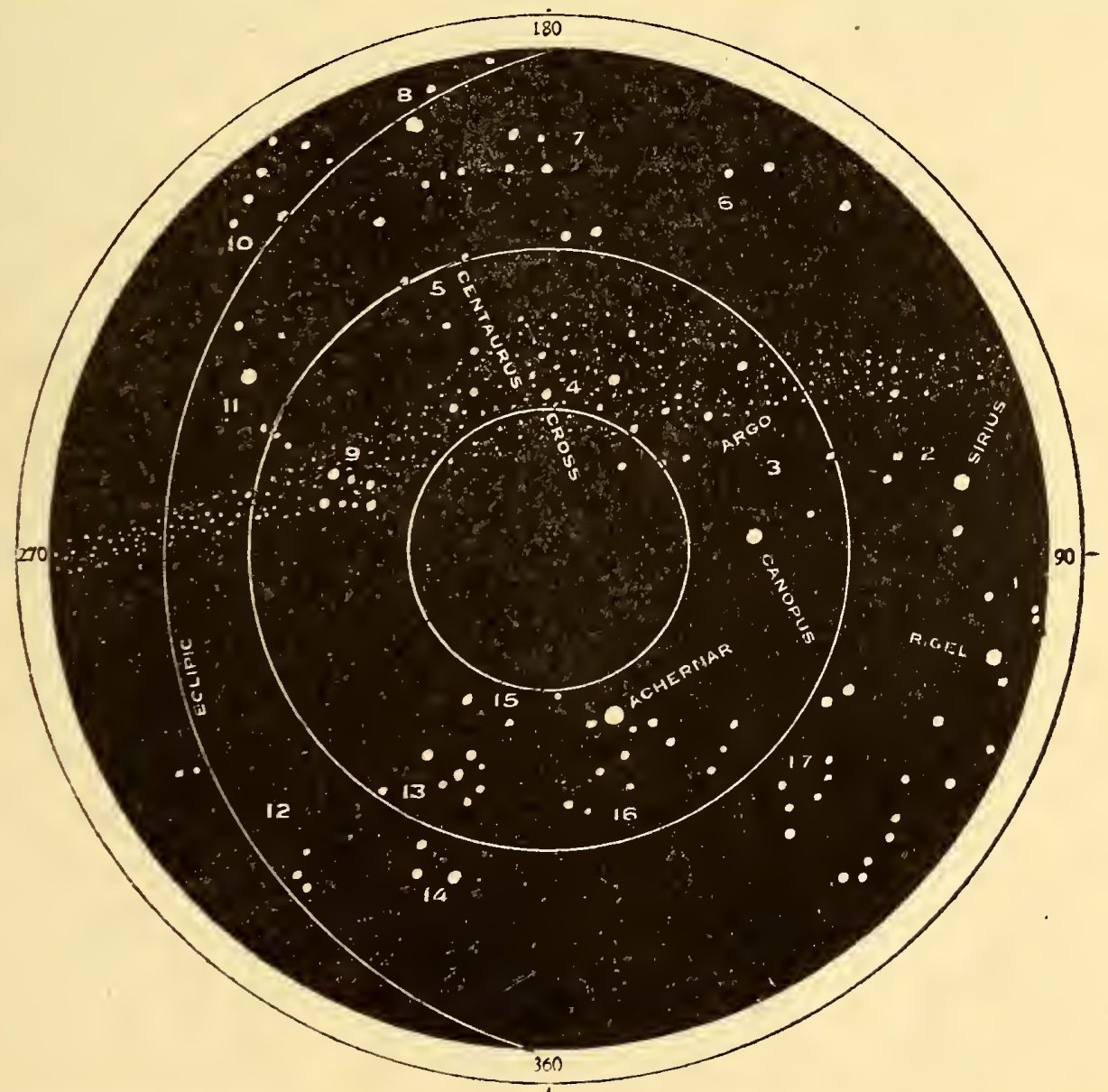

racing yacht with deep, heavy keel. The bow is lacking, due to an accident that occurred while the fleece hunters were crossing the Bosporus. In the keel is Canopus, the most lucid of the southern stars, and second only to Sirius, in brilliancy. Canopus can be seen low on the southern horizon from States of the United States south of North Carolina, but to most of the visitors to the Canal it is an entirely new star. It is one of the most distant of the stars, is said to be ten thousand times as bright as the sun, and 250 times as 


\section{Wholesale - -}

- Retail

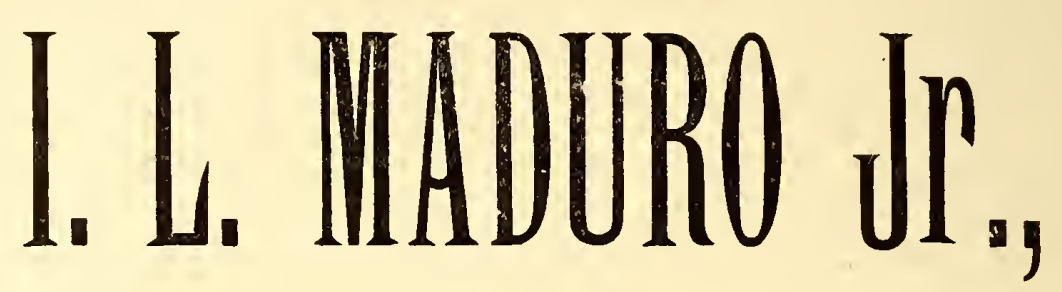

Fifth St. and Cathedral Plaza so PANAMA go P. O. BOX 281

Postal Cards, Curios, Souvenirs, Maps, Books and Stationery, Toys, Notions, Chinese and Japanese Novelties.

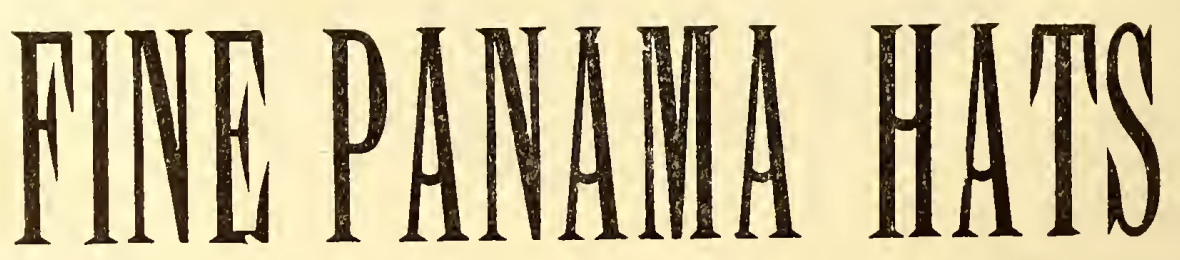

FOR

Ladies and Gentlemen A SPECIALTY - - 
bright as Sirius; in fact it is the brightest of all the stars, but its great distance from us makes it seem less lucid than Sirius. It was an object of worship in Egypt, China, and Chaldea. The second brightest star in Argo Navis is that designated Eta, but it is remarkable less for its brightness than for its variableness, sometimes being as bright as Canopus, and again being invisible.

Immediately east of Argo Navis, visible during the eight months from January to September, at hours varying from 2 a. m. in January to $8 \mathrm{p} . \mathrm{m}$. in September, is Southern Crux, the Southern Cross. This constellation is: Cross. greatly overrated in one sense, because it is nothing like so conspicuous as Orion, Cassiopeia, the Great Dipper, Scorpio, nor to my mind as the great square of Pegasus; but it is justly famed as the pointer to the south pole, as the most clearly defined of the southern constelations, and because of its romantic influence on the men who discovered and colonized Latin-America. It was not commonly known to Europeans before the time of Columbus; and the effect upon the old navigators can be well imagined, as they saw the familiar stars by which they were accustomed to steer change position in the sky, and this new and brilliant constellation gradually rise. It was a time of even greater superstition than this in which we live, a day of mysticism, and there was varying significance, to the men who murdered in the name of Christ, in the spectacle of this cross seeming to beckon them toward the south. The constellation is about $\mathbf{3 0}$ degrees north of the south pole, towards which it points by means of a line drawn through its brightest star (alpha) from the star immediately above it (gamma). Alpha shows itself a binary under the telescope. To the astrologers of Asia Minor the cross was known as a part of Cen- 


\section{Genuine Panama Hats}

\section{R. LINCE \&CO.}

No. 493 Central Avenue

Opposite P. R. R. Station

\section{Wholesale - Retail - Export}

Our principal business is the exportation of Panama Hats to foreign countries, but we also retail them at prices above competition. Mail orders promptly attended to

We will be glad to have you inspect our fine stock 
taurus, to which it really belongs, since it is surrounded on three sides by the stars of this constellation.

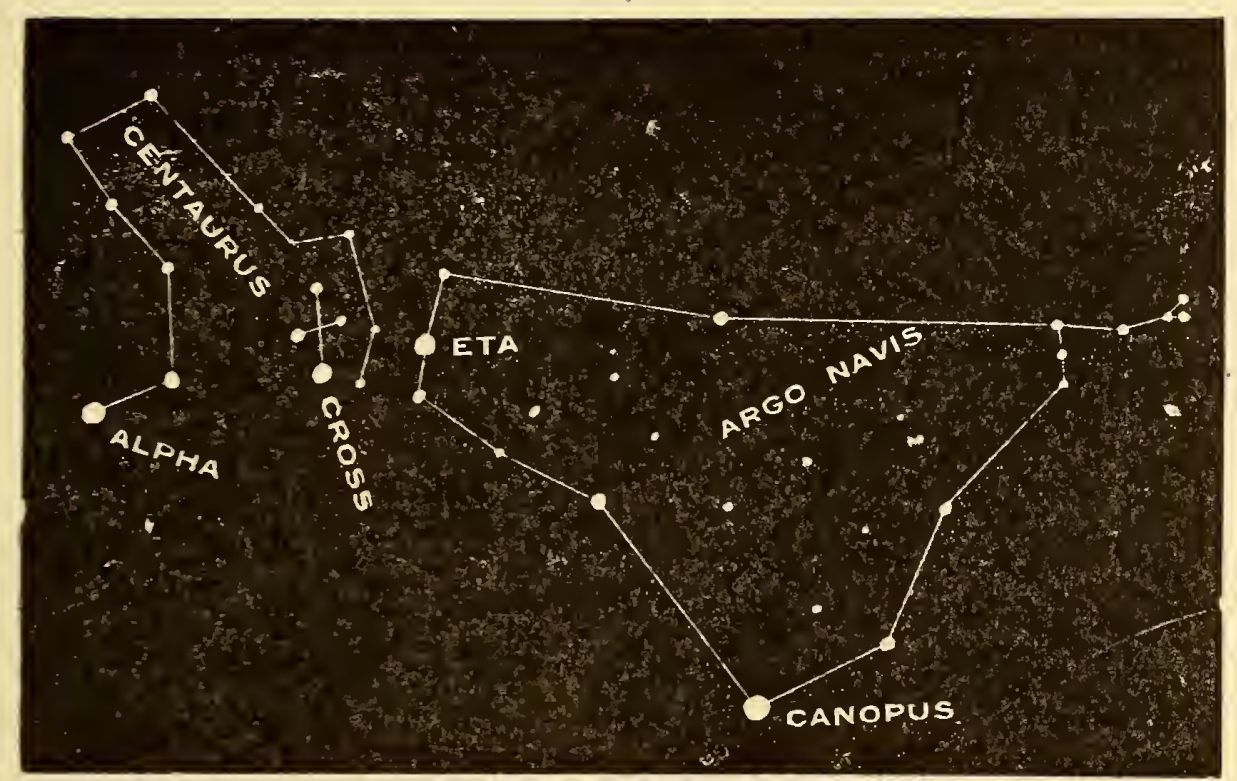

Centaurus follows Argo Navis and The Cross in the procession from east to west, completing the brilliant pageant of the southern skies. Its brightest stars,

Centaurus. Alpha and Beta, point directly to the cross, Alpha and they are among the most lucid stars.

Centauri. Alpha ranks next to Canopus in brilliancy, and is distinguished as being the nearest of all the stars. It is a binary, and its brilliancy is reckoned as four times that of the sun. It was known to the Egyptians, among whom it was an object of worship.

When Argo Navis, Crux, and Centaurus have run their course, the southern sky shows few stars of remarkable brilliancy, and no constellations of great import-

Achernar. ance. At the southern end of the northern constellation Eridanus is the bright star Achernar, not visible from latitudes north of 32 north. It is about 32 degrees north of the south pole, and is equal in brilliancy to Arcturus, Vega, and Capella. It likewise was an object of worship by the ancients. 


\section{J. J. GARCIA, D. D.S. AMERICAN DENTIST}

Graduate of the Denta1 Dept. of the University

of Michigan, U. S. A.

President of the Board of Dental Examiners

All kinds of dental work done in a highly scientific manner and at moderate prices

DR. GARCIA MAKES

GOLD PLLLINGS', ORTHODONTIA AND CROWN AND BRIDGe WORK SPPCIALTIES

Satisfaction guaranteed or no pay

\section{ALL OPERATIONS PAINLESS}

CONSULTATIONS FREE

Dr. Garcia is assisted by Dr. E. D. Santos, a Specialist in Prosthetic Dentistry 


\section{The Canal Medal.}

In his farewell speech on the dock at Colon on November 17,1906 , just as he was about to leave the Isthmus, President Roosevelt said, "I shall see if it is not possible to pro-

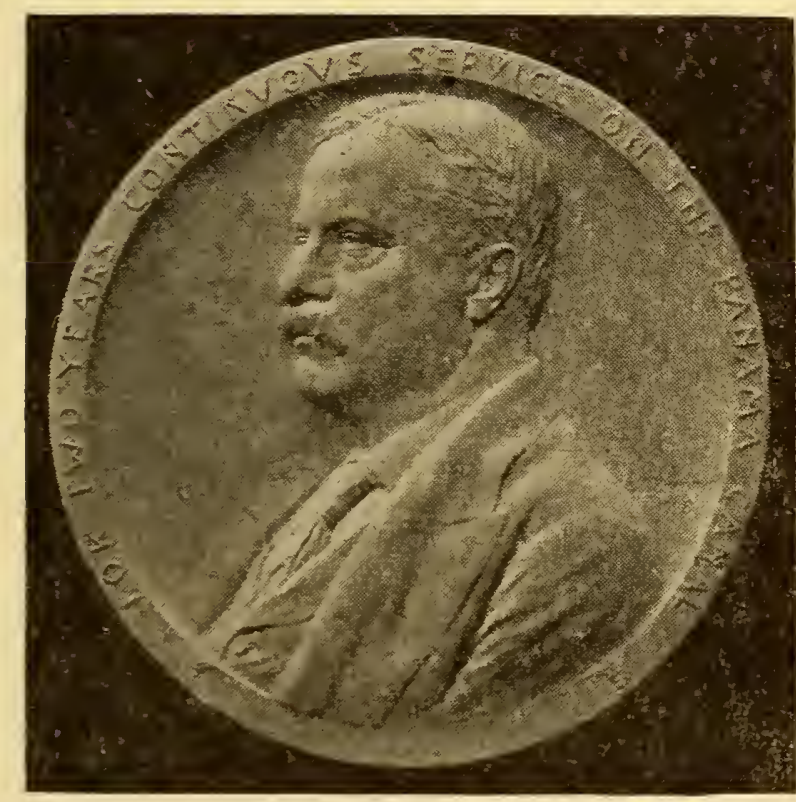

vide for some little memorial,somemark, some badge, which will always distinguish the man who for a certain space of time has done his work well on the Isthmus, just as the button of the Grand Army distinguishes the man who did his work well in the CivilWar."

The outcome of this speech was the Canal Service Medal pictured on this page. It

is of bronze made from brass, copper, and tin taken from old French equipment. It is $11 / 2$ inches in diameter, about the size of a peso. On the face is a three-quarter bust portrait of Theodore Roosevelt, underneath it a space for the service record, and around the rim the words, "For two years continuous service on the Panama Canal." On the obverse is a

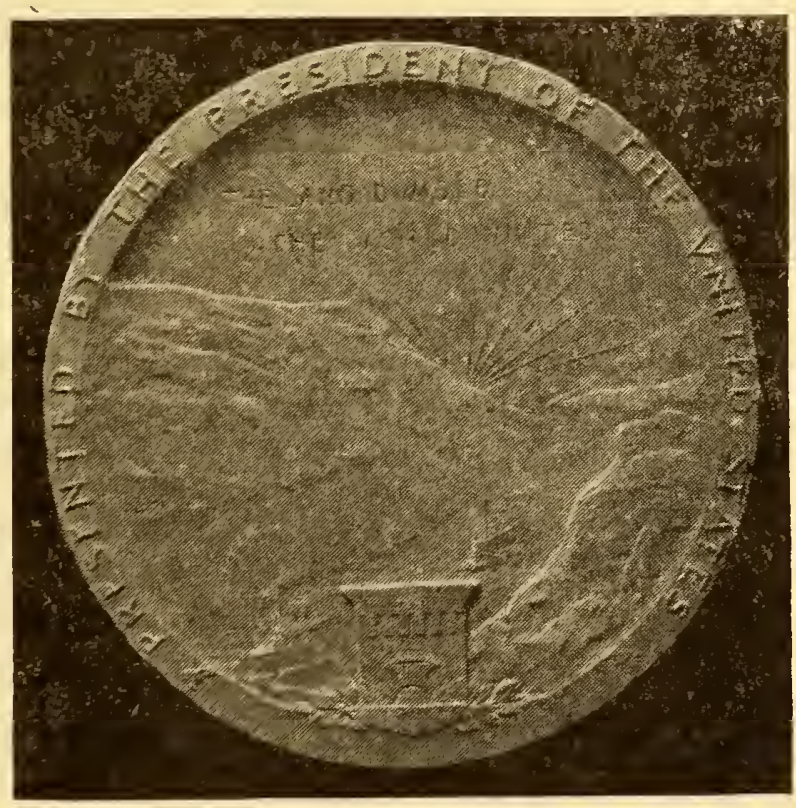

,

picture of Culebra Cut with ships passing through, the seal of the CanalZone, a name plate and the inscriptions shown in the illustration. A medal is awarded to every American employe who serves two years continuously on the isthmus, and a service bar is awarded for each two years additional service. - MR 22928—16 
WHILE IN PANAMA BE SURE TO VISIT THE FAMOUS

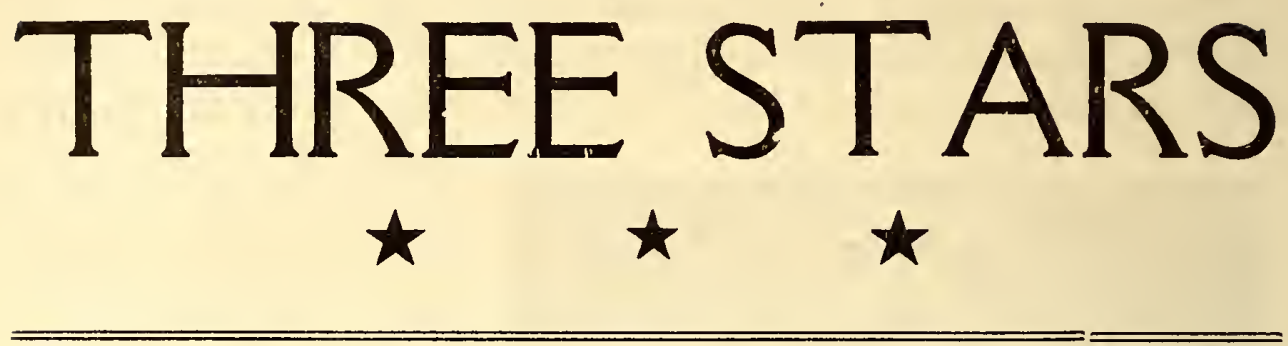

\section{... WING ON LUNG ...}

IMPORTER OF

Chinese and Japanese Silks, Canton Linen Embroideries and Drawn Thread Work, Ivory, Satsuma, Cloisonne, Sandal-Wood and Porcelain Ware, Beautifully Embroidered Kimonos. Shirtwais t Patterns Dressing Sacks, and innumerable other Fancy Goods from China and Japan

Open until 8.30 p. m. ..- and on Sundays to 2 p. m.

158-160 Central Avenue near Santa Ana Park PA N A M A, R.P.

... Prices very Moderate ... 


\title{
Treaties Affecting The Canal.
}

\author{
Clayton-Bulwer Treaty, July 5, 1850.
}

The United States of America and Her Britannic Majesty, being desirous of consolidating the relations of amity which so happily subsist between them, by setting forth and fixing in a Convention their views and intentions with reference to any means of communication by ship canal, which may be constructed between the Atlantic and Pacific Oceans by the way of the River San Juan de Nicaragua and either or both of the Lakes of Nicaragua or Managua, to any port or place on the Pacific Ocean,-The President of the United States has conferred full powers on John M. Clayton, Secretary of State of the United States; and Her Britannic Majesty on the Right Honorable Sir Henry Lytton Bulwer, a member of Her Majesty's Most Honorable Privy Council, Knight Commander of the Most Honorable Order of the Bath, and Envoy Extraordinary and Minister Plenipotentiary of Her Britannic Majesty to the United States, for the aforesaid purpose; and the said Plenipotentiaries having exchanged their full powers which were found to be in proper form, have agreed to the following articles:

\section{Article I.}

The Governments of the United States and Great Britain hereby declare, that neither the one nor the other will ever obtain or maintain for itself any exclusive control over the said Ship Canal; agreeing that neither will ever erect or maintain any fortifications commanding the same, or in the vicinity thereof, or occupy, or fortify, or colonize, or assume or exercise any dominion over Nicaragua, Costa Rica, the Mosquito Coast, or any part of Central America; nor will either make use of any protection which either affords or may afford, or any alliance which either has or may have, to or with any State or People for the purpose of erecting or maintaining any such fortifications, or of occupying, fortifying, or colonizing Nicaragua, Costa Rica, the Mosquito Coast or any part of Central America, or of assuming or exercising dominion over the same; nor will the United States or Great Britain take advantage of any intimacy or use any alliance, connec- 


\section{ESTABLISHED IN 1865 \\ Ehrman \& Co.}

BANKERS

SUCCESSORS TO HENRY EHRMAN

PANAMA

Collections, Bills of Exchange, Cable Transfers, Cheques and Wells, Fargo \& Co. Money Orders.

\section{AGENTS OF}

Compañia Sud Americana de Commercial Union Assurance Vapores. Co., Ltd., London.

Compagnie Générale Transtt- Marine Insurance Co., Ltd., lantique. London.

\section{Hotel Central}

Cathedral Plaza, Panama

Principal Hotel in the City $==$ Located in business center

Airy and well-ventilated rooms. Newly renovated. Electric light and bells, shower and tub baths. From $\$ 3$ to $\$ 7$ gold per day, American plan. Excellent wines, liquors and beers on draught. Dining room open until 9 p. m. Dinner concert every Sunday evening. Saloon and Barber Shop in connection with the hotel. Palm Garden -

First=Class Table-French and American Dishes

Luncheon, 75 cents gold. Dinner, \$1 gold 
tion or influence that either may possess with any State or Government through whose territory the said Canal may pass for the purpose of acquiring or holding, directly of indirectly, for the citizens or subjects of the one, any rights or advantages in regard to commerce or navigation through the said canal which shall not be offered on the same terms to the citizens or subjects of the other.

Article II.

Vessels of the United States or Great Britain, traversing the said Canal shall, in case of war between the contracting parties, be exempted from blockade, detention or capture, by either of the belligerents; and this provision shall extend to such a distance from the two ends of the said Canal as may hereafter be found expedient to establish.

\section{Article III.}

In order to secure the construction of the said Canal, the contracting parties engage that, if any such Canal shall be undertaken upon fair and equitable terms by any parties having the authority of the local Government or Governments through whose territory the same may pass, then the persons employed in making the said Canal and their property used, or to be used, for that object, shall be protected, from the commencement of the said Canal to its completion, by the Governments of the United States and Great Britain, from unjust detention, confiscation, seizure or any violence whatsoever.

OFFICES:

POST OFFICE:

Imperial Hotel

(Opp. P. R. R. Sta.)

Panama, R. de P.

P. 0. Box 29

Ancon

Canal Zone

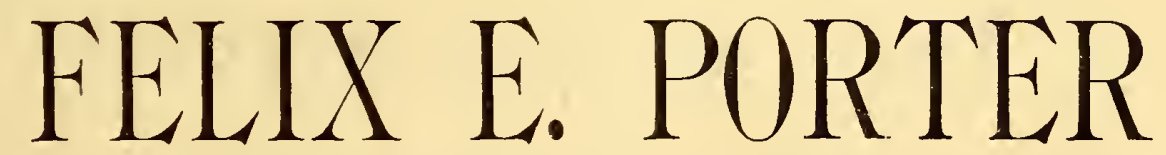

Attorney-at-Law

(Late Asst. Pros. Atty. Canal Zone)

CABLE: "Fep"

PHONE: $\begin{aligned} & \text { P. R. R. } 109 \\ & \text { Panama, 284-B }\end{aligned}$ 


\section{PO YUEN \& CO.}

\section{COMMISSION MERCHANTS}

Nos. 208-210-212 E. 13th ST.

\section{PANAMA OITY}

ExPORTERs and IMPORTERs of all kinds of merchandise. Such as articles of silk, direct from China and Japan. Fancy Oriental bric-a-brac.

Satsuma Ware-Beautiful kimonos from Japan. Handcarved ivory. Jewel and toilet boxes and stationery. Porcelain ware.

Our Prices are very reasonable

Wholesale and retail dealers in all kinds of provisions

\section{Liquors of all kinds}

VISIT THIS ESTABLISHMENT

The Stock in hand is the largest in the Country 


\section{Article IV.}

The contracting parties will use whatever influence they respectively exercise, with any State, States or Governments possessing, or claiming to possess, any jurisdiction or right over the territory which the said Canal shall traverse, or which shall be near the waters applicable thereto; in order to induce such States, or Governments, to facilitate the construction of the said Canal by every means in their power: and furthermore, the United States and Great Britian agree to use their good offices, wherever or however it may be most expedient, in order to procure the establishment of two free Ports,- one at each end of the said Canal.

\section{Article V.}

The contracting parties further engage that, when the said Canal shall have been completed they will protect it from interruption, seizure or unjust confiscation, and that they will guarantee the neutrality thereof, so that the said Canal mayforever be open and free, and the capital invested therein, secure. Nevertheless, the Governments of the United States and Great Britain, in according their protection to the construction of the said Canal, and guaranteeing its neutrality and security when completed, always understand that, this protection and guaran tee are granted conditionally, and may.be withdrawn by both Governments, or either Government, if both Governments or either Government, should deem that the persons or company undertaking or managing the same, adopt or establish such regulations concerning the traffic thereupon, as are contrary to the spirit and intention of this Convention,--either by making unfair discriminations in favor of the commerce of one of the contracting parties over the commerce of the other, or by imposing oppressive exactions or unreasonable tolls upon passengers, vessels, goods, wears, merchandise, or other articles. Neither party, however, shall withdraw the aforesaid protection and guarantee without first giving six months notice to the other.

\section{Article VI.}

The contracting parties in this Convention engage to invite every State with which both or either have friendly intercourse, to enter into stipulations with them similar to those which they have entered into with each other; to the end that all other States may share in the honor and advantage of having contributed to a work of such general interest and importance as the Canal herein contemplated. 


\section{SINGER SEWING IIHEHANES}

BEST THE WORLD OVER

\section{Because OF}

Quality

Price
Prestige

Variety

\section{Terms $==$ = Unequalled for Liberality}

Singer Stores everywhere carry a full assortment of Sewing Machine supplies including needles for all makes of machines.

\section{SINGER SEWING MACHINE COMPANY}

EIGHTH STREET (Rear Cathedra1)

$$
\text { PANA M A CITY }
$$

19 Front Street, Colon 
And the contracting parties likewise agree that, each shall enter into Treaty stipulations with such of the Central American States, as they may deem advisable, for the purpose of more effectually carrying out the great design of this Convention, namely, - that of constructing and maintaining the said Canal as a ship-communication between the two Oceans, for the benefit of mankind, on equal terms to all, and of protecting the same; and they, also, agree that, the good offices of either shall be employed, when requested by the other, in aiding and assisting the negotiations of such treaty stipulations; and should any differences arise as to right or property over the territory through which the said Canal shall pass,-between the States or Governments of Central America, - and such differences should, in any way, impede or obstruct the execution of the said Canal, the Governments of the United States and Great Britain will use their good offices to settle such differences in the manner best suited to promote the interests of the said Canal, and to strengthen the bonds of friendship and alliance which exist between the contracting parties.

\section{ArtiCle VII.}

It being desirable that no time should be unnecessarily lost in commencing and constructing the said Canal, the Governments of the United States and Great Britain determine to give their support and encouragement to such persons, or company, as may first offer to commence the same, with thenecessary capital, the consent of the local authorities, and on such principles as accord with the spirit and intention of this Convention; and if any persons, or company, should already have, with any State through which the proposed Ship-Canal may pass, a contract for the construction of such a canal as that specified in this Convention,- - to the stipulations of which contract neither of the contracting parties in this Convention have any just cause to object,- and the said persons, or company, shall moreover, have made preparations and expended time, money, and trouble on the faith of such contract, it is hereby agreed that such perscns, or company shall have a priority of claim over every other person, persons, or company to the protection of the Governments of the United States and Great Britain, and be allowed a year, from the date of the exchange of the ratifications of this Convention for concluding their arrangements and presenting evidence of sufficient capital subscribed to ac- 
Isthmian Phone No. 36

PANAMA

Opposite Cathedral

Opposite P. R. R. Station COLON

Isihmian Phone No. 95

\section{VIBERT \\ \& \\ DIXON}

Reading Matter, Stationery, Kodaks and

Photo Supplies, Powell's Candy,

Waterman's Ideal Foun-

tain Pens, Post

Cards,

Souvenirs, Man-

ufacturers "La Prueba"

Cigars, Dealers Leaf Tobacco, Importers Havana Cigars, Panama Hats

\section{Developing Kodak Film and Printing on Velox a Specialty}


complish the contemplated undertaking; it being understood that if, at the expiration of the aforesaid period, such persons, or company be not able to commence and carry out the proposed enterprise, then the Governments of the United States and Great Britain shall be free to afford their protection to any other persons, or company, that shall be prepared to commence and proceed with the construction of the Canal in question.

\section{Article Viti.}

The Governments of the United States and Great Britain having not only desired in entering into this Convention, to accomplish a particular object, but, also, to establish a general principle, they hereby agree to extend their protection, by Treaty stipulations, to any other practicable communications, whether by Canal or railway, across the Isthmus which connects North and South America; and especially to the inter-oceanic communications,-should the same prove to be practicable, whether by canal or railwaywhich are now proposed to be established by the way of Tehuantepec, or Panama. In granting, however, their joint protection to any such Canals or railways, as are by this Article specified, it is always understood by the United States and Great Britain, that the parties constructing or owning the same, shall impose no other charges or conditions of traffic thereupon, than the aforesaid Governments shall approve of as just and equitable; and, that the same Canals or railways being open to the citizens and subjects of the United States, and Great Britain on equal terms, shall also, be open on like terms to the citizens and subjects of every other State which is willing to grant thereto, such protection as the United. States and Great Britain engage to afford.

\section{Article IX.}

The ratifications of this Convention shall be exchanged at Washington, within six months from this day, or sooner, if possible.

In faith whereof, we, the respective Plenipotentiaries, have signed this Convention, and have hereunto affixed our Seals.

Done, at Washington, the nineteenth day of April, Anno. Domini one thousand eight hundred and fifty.

$$
\text { John M. Clayton. }
$$




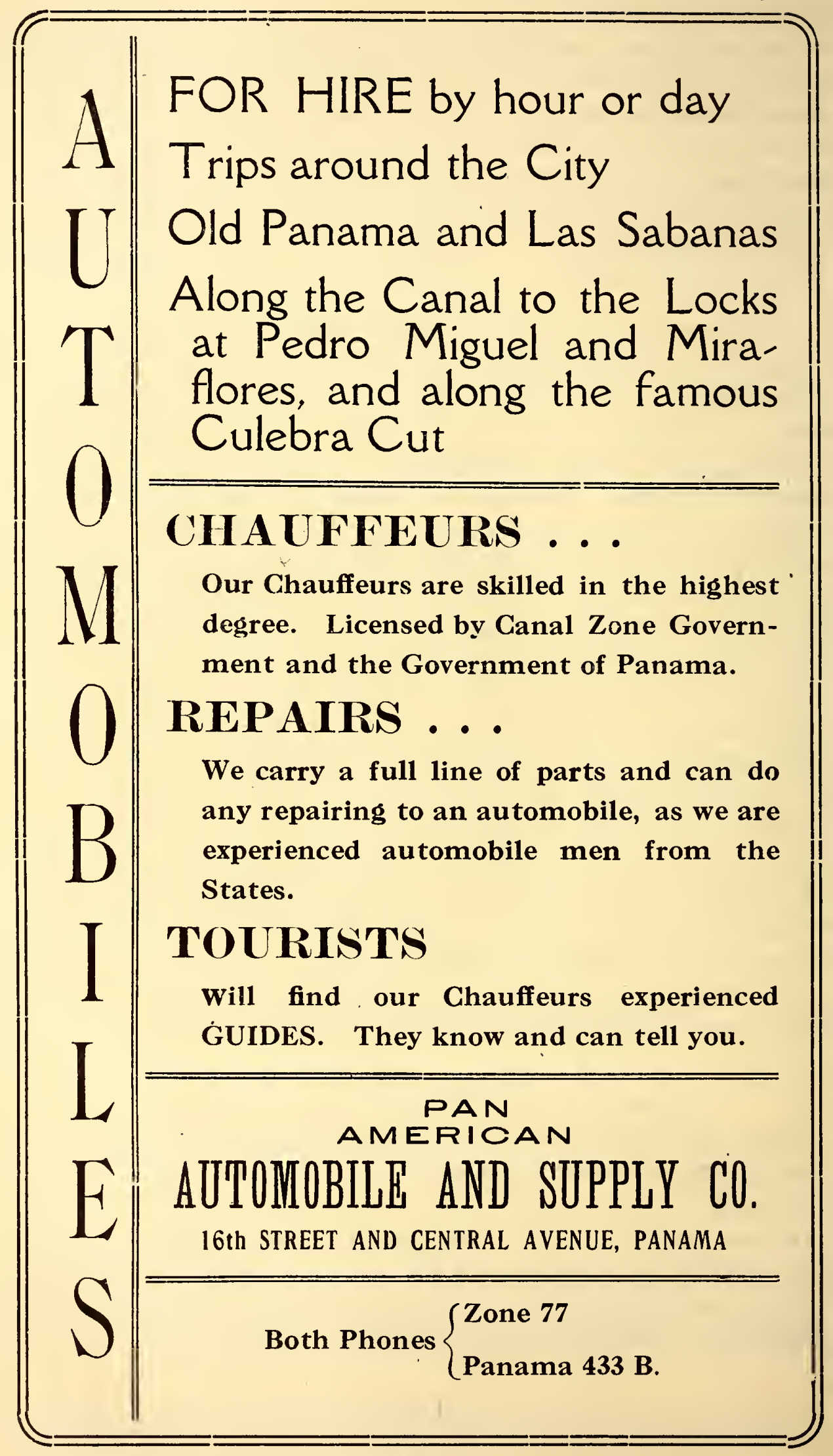


Hay-Pauncefote Treaty, Feb. 22, 1902.

Whereas a Convention between the United States of America and the United Kingdom of Great Britain and Ireland, to facilitate the construction of a ship canal to connect the Atlantic and Pacific Oceans, by whatever route may be considered expedient, and to that end to remove any objection which may arise out of the Convention of the 19 th of April, 1850, commonly called the Clayton-Bulwer treaty, to the construction of such canal under the auspices of the Government of the United States, without impairing the "general principle" of neutralization established in Article VIII of that Convention, was concluded and signed by their respective plenipotentiaries at the city of Washington on the 18th day of November, 1901, the original of which Convention is word for word as follows:

The United States of America and His Majesty Edward the Seventh, of the. United Kingdom of Great Britain and Ireland, and of the British Dominions beyond the Seas, King, and Emperor of India, being desirous to facilitate the construction of a ship canal to connect the Atlantic and Pacific Oceans, by whatever route may be considered expedient, and to that end to remove any objection which may arise out of the Convention of the 19th of April, 1850, commonly called the Clayton-Bulwer Treaty, to the construction of such canal under the auspices of the Government of the United States, without impairing the "general principle" of neutralization established in Article VIII of that Convention, have for that purpose appointed as their Plenipotentiaries:

The President of the United States, John Hay, Secretary of State of the United States of America;

And His Majesty Edward the Seventh, of the United Kingdom of Great Britain and Ireland, and of the British Dominions beyond the Seas, King, and Emperor of India, the Right Honorable Lord Pauncefote, G. C. B., G. C. M. G., His Majesty's Ambassador Extraordinary and Plenipotentiary to the United States;

Who having communicated to each other their full powers which were found to be in due and proper form, have agreed upon the following Articles:-

\section{ARTICLE I.}

The high Contracting Parties agree that the present Treaty shall supersede the afore-mentioned Convention of the 19th April, 1850. 


\section{The French Bazaar}

\section{Latest Parisian Novelties \\ For Ladies and Gentlemen}

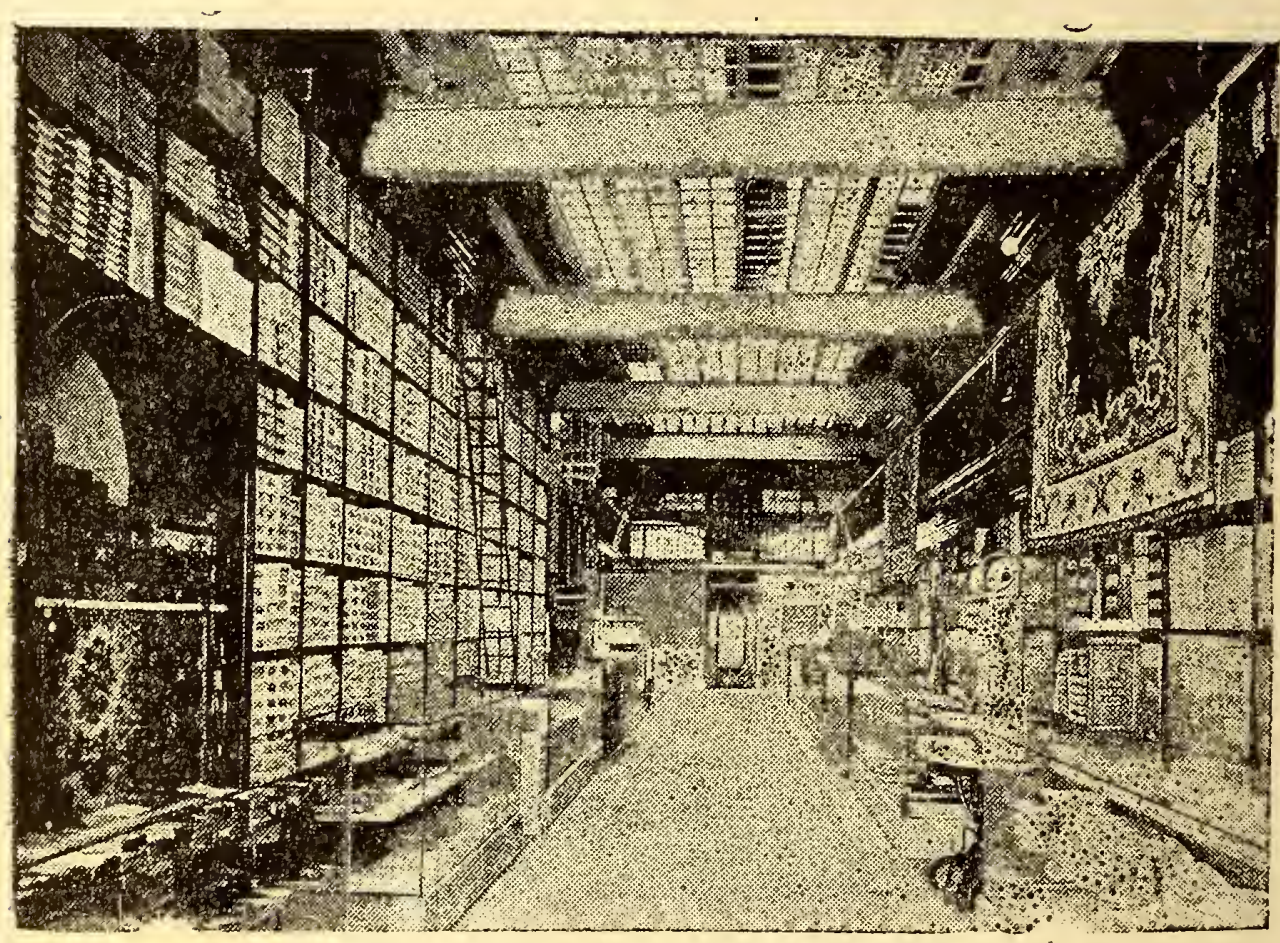

A Department in the French Bazaar

HEURTEMATTE \& Co., Incorporated Corner Sosa and 8th Streets Opposite Panama Banking Co.

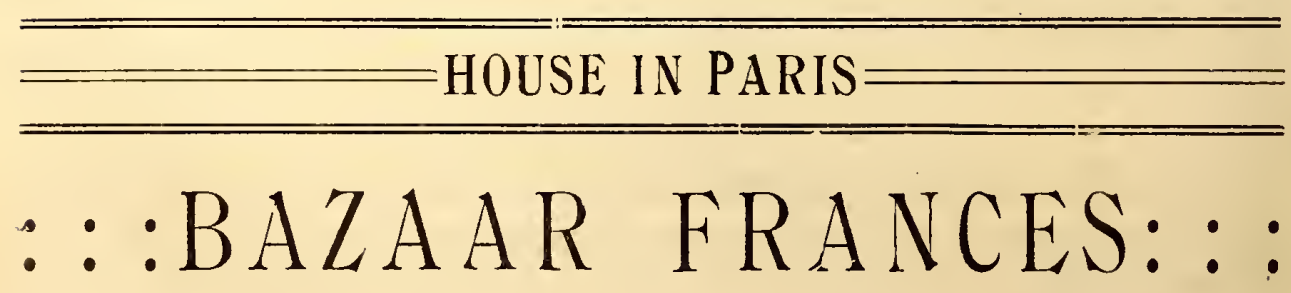




\section{Article II.}

It is agreed that the Canal may be constructed under the auspices of the Government of the United States, either directly at its own cost, or by gift or loan of money to individuals or Corporations, or though subscription to or purchase of stock or shares, and that, subject to the provisions of the present Treaty, the said Government shall have and enjoy all the rights incident to such construction, as well as the exclusive right of providing for the regulation and management of the canal.

\section{ARTICLE III.}

The United States adopts, as the basis of the neutralization of such ship canal, the following Rules, substantially as embodied in the Convention of Constantinople, signed the 28th October, 1888, for the free navigation of the Suez Canal, that is to say:

1. The Canal shall be free and open to the vessels of commerce and of war of all nations observing these Rules, on terms of entire equality, so that there shall be no discrimination against any such nation, or its citizens or subjects, in respect of the conditions or charges of traffic, or otherwise Such conditions and charges of traffic shall be just and equitable.

2. The Canal shall never be blockaded, nor shall any right of war be exercised nor any act of hostility be committed within it. The United States, however, shall be at liberty to maintain such military police along the Canal as may be necessary to protect it against lawlessness and disorder.

3. Vessels of war of a belligerent shall not revictual nor take any stores in the Canal except so far as may be strictly necessary; and the transit of such vessels through the Canal shall be effected with the least possible delay in accordance with the Regulations in force, and with only such intermission as may result from the necessities of the service.

Prizes shall be in all respects subject to the same Rules as vessels of war of the belligerents.

4. No belligerent shall embark or disembark troops, munitions of war, or warlike materials in the Canal, except in case of accidental hindrance of the transit, and in such case the transit shall be resumed with all possible dispatch.

5. The provisions of this Article shall apply to waters adjacent to the Canal, within three marine miles of either 


\section{International Hotel}

Fronting Railroad Plaza, Panama

New : Fireproof : Modern in all Appointments

CUISINE UNEXCELLED

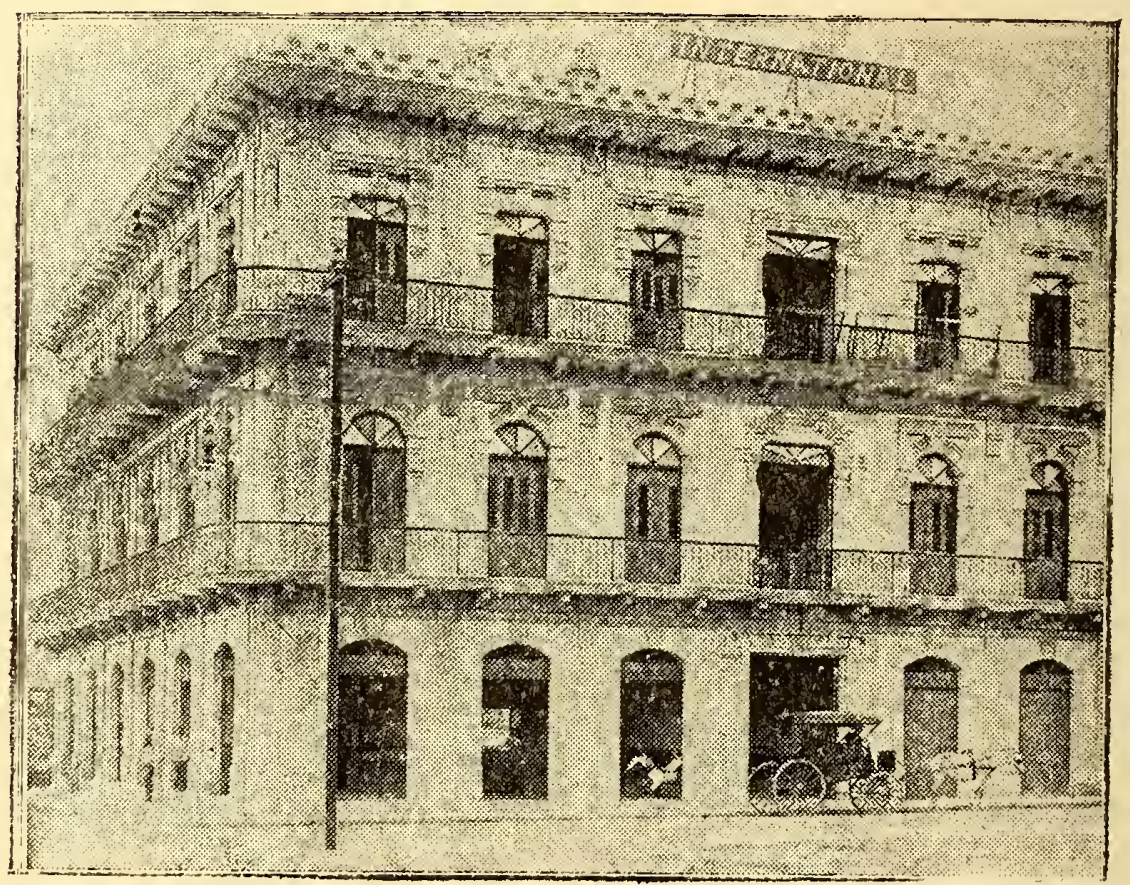

American Plan : Cafe : European Plan A la Carte from 9 a. m. till 11 p. m.

The International offers to Tourists and Travelers an Ideal Stopping Place

Hot and Cold Water Tub and Shower Baths

ANDREW W. DEWLING,

Manager 
end. Vessels of war of a belligerent shall not remain in such waters longer than twenty-four hours at any one time, except in case of distress, and in such case, shall depart as soon as possible; but a vessel of war of one belligerent shall not depart within twenty-four hours from the departure of a vessel of war of the other belligerent.

6. The plant, establishments, buildings, and all works necessary to the construction, maintenance, and operation of the Canal shall be deemed to be part thereof, for the purposes of this Treaty, and in time of war, as in time of peace, shall enjoy complete immunity from attack or injury by belligerents, and from Acts calculated to impair their usefulness as part of the Canal.

\section{ARTICLE IV.}

It is agreed that no change of territorial sovereignty or of the international relations of the country or countries traversed by the before-mentioned Canal shall affect the general principle of neutralization or the obligation of the High Contracting Parties under the present Treaty.

\section{Article V.}

The present Treaty shall be ratified by the President of the United States, by and with the advice and consent of the Senate thereof, and by His Britannic Majesty; and the ratifications shall be exchanged at Washington or at London at the earliest possible time within six months from the date hereof.

In faith whereof the respective Plenipotentiaries have signed this Treaty and thereunto affixed their Seals.

Done in duplicate at Washington, the 18th day of November, in the year of Our Lord one thousand nine hundred and one.

$$
\begin{array}{ll}
\text { John Hay. } & \text { [SEal.] } \\
\text { Pauncefote. } & \text { [Seal.] }
\end{array}
$$

And Whereas the said Convention has been duly ratified on both parts, and the ratification of the two Governments were exchanged in the city of Washington on the twenty-first day of February, one thousand nine hundred and two;

Now, therefore, be it known that I, Theodore Roosevelt, President of the United States of America, have caused the said Convention to be made public, to the end that the same, and every Article and Clause thereof may be observed and fulfilled with good faith by the United States and the citizens thereof. 


\section{Panama Railroad News Agency}

At all Railroad Stations

\section{Victor Store, Panama City}

Central Avenue opposite Railroad Station

Five minutes from Hotel Tivoli

\section{Lindo's Store, Panama City}

Central Avenue near 11th Street

Victors and Victrolas, Pianos and Pianolas, Draper and Maynard Sporting Goods, Panama

Hats, Souvenirs, Books and Stationery, Periodicals, Candies 
In witness whereof I have hereunto set my hand and caused the Seal of the United States to be affixed.

Done at the city of Washington, this twenty-second day of February, in the year of Our Lord one thousand nine hundred and two, and of the Independence of the United States the one hundred and twenty-sixth.

[SEAL.]

By the President:

THEODORE ROOSEvelT.

JoHN Hay,

Secretary of State.

Treaty between the United States and the Republic of Panama, Feb. 26, 1904.

Whereas, a Convention between the United States of America and the Republic of Panama to insure the construction of a ship canal across the Isthmus of Panama to connect the Atlantic and Pacific Oceans, was concluded and signed by their respective Plenipotentiaries at Washington, on the eighteenth day of November, one thousand nine hundred and three, the original of which Convention, being in the English language, is word for word as follows:

ISTHMIAN CANAL CONVENTION.

The United States of America and the Republic of Panama being desirious to insure the construction of a ship canal across the Isthmus of Panama to connect the Atlantic and Pacific Oceans, and the Congress of the United States of America having passed an act approved June 28, 1902, in furtherance of that object, by which the President of the United States is authorized to acquire within a reasonable time the control of the necessary territory of the Republic of Colombia, and the sovereignty of such territory being actually vested in the Republic of Panama, the high contracting parties have resolved for that purpose to conclude a convention and have accordingly appointed as their plenipotentiaries,-

The President of the United States of America, John Hay, Secretary of State, and

The Government of the Republic of Panama, Philippe Bunau-Varilla, Envoy Extraordinary and Minister Plenipotentiary of the Republic of Panama, thereunto specially empowered by said government, who af ter communicating with each other their respective full powers, found to be in good and due form, have agreed upon and concluded the following articles: 


\section{AUTOMOBILES}

Touring Cars for all

Points of Interest

\section{Morrice's Garage}

OFFICE: Panama Hardware Co.

..... Cathedral Plaza

PANAMA

TELEPHONES: Local 278; Canal Zone and Colon 60

\section{VISIT}

Camp Elliott, Camp Otis, CULE= BRA CUT, PEDRO MIGUEL and MIRAFLORES LOCKS, OId Pan= ama, Balboa, by Automobile

\section{AUTOMOBILES}




\section{Article I.}

The United States guarantees and will maintain the independence of the Republic of Panama.

\section{Article II.}

The Republic of Panama grants to the United States in perpetuity the use, occupation and control of a zone of land and land under water for the construction, maintenance, operation, sanitation and protection of said canal of the width of ten miles extending to the distance of five miles on each side of the center line of the route of the canal to be constructed; the said zone beginning in the Garibbean Sea three marine miles from mean low water mark and extending to and across the Isthmus of Panama into the Pacific Ocean to a distance of three marine miles from mean low water mark with the proviso that the cities of Panama and Colon and the harbors adjacent to said cities, which are included within the boundaries of the zone above described, shall not be included within this grant. The Republic of Panama further grants to the United States in perpetuity the use, occupation and control of any other lands and waters ou tside of the zone above described which may be necessary and convenient for the construction, maintenance, operation, sanitation and protection of the said Canal or of any auxiliary canals or other works necessary and convenient for the construction, maintenance, operation, sanitation and protection of said enterprise.

The Republic of Panama further grants in like manner to the United States in perpetuity all islands within the limits of the zone above described and in addition thereto the group of small islands in the Bay of Panama, named Perico, Naos, Culebra, and Flamenco.

\section{ARticle III.}

The Republic of Panama grants to the United States all the rights, power and authority within the zone mentioned and described in Article II of this agreement and within the limits of all auxiliary lands and waters mentioned and described in said Article II which the United States would possess and exercise if it were the sovereign of the territory within which said lands and waters are located to the entire exclusion of the exercise by the Republic of Panama of any such sovereign rights, power or authority. 


\section{Article IV.}

As rights subsidiary to the above grants the Republic of Panama grants in perpetuity to the United States the right to use the rivers, streams, lakes and other bodies of water within its limits for navigation, the supply of water or waterpower or other purposes, so far as the use of said rivers, streams, lakes and bodies of water and the waters thereof may be necessary and convenient for the construction, maintenance, operation, sanitation and protection of the said Canal.

\section{Article V.}

The Republic of Panama grants to the United States in perpetuity a monopoly for the construction, maintenance and operation of any system of communication by means of canal or railroad across its territory between the Caribbean Sea and the Pacific Ocean.

\section{Article VI.}

The grants herein contained shall in no manner invalidate the titles or rights of private land holders or owners

liet the Greatest Souvenir of the Panama Canal

Beatiful Jewel Stones from the Bottom of the?

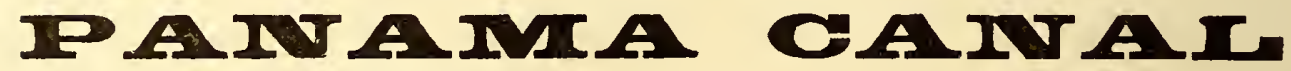

BRILLIANTLY POLISHED

Inset or Set in all kinds of Gold and Silver Mounting's

Reasonable - - $\quad$ - $\quad$ - $\quad$ - Prices

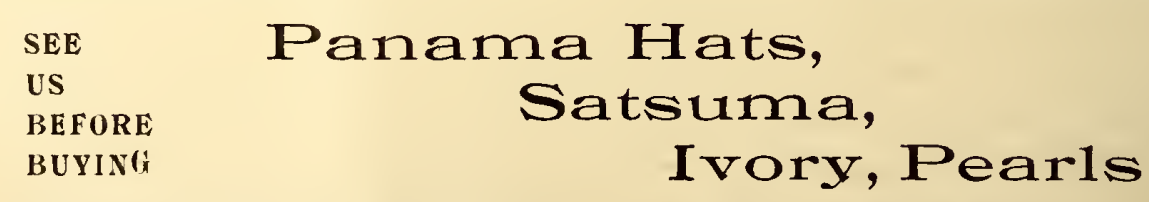

\section{Panama Gem and Curio Collectors}




\section{INTERNATIONAL CORRRSPONDENCE SCHOOLS OF SCRANTON, PA. \\ office near R. R. Station, Panama city}

The I. C. S. make it easy to learn what Employers and the Public want done, and are glad to pay for

\section{COURSES:}

Business, Agriculture, Engineeríng, Trades, and Modern Languages with Standard Edison Phonograph Outfit

\section{A. ATChISON, Gen. Agent - - - Ancon, C. Z.}

of private property in said zone or in or to any of the lands or waters granted to the United States by the provisions of any Article of this treaty, nor shall they interfere with the rights of way over the public roads passing through the said zone or over any of the said lands or waters unless said rights of way or private rights shall conflict with the rights herein granted to the United States in which case the rights of the United States shall be superior. All damages caused to the owners of private lands or private property of any kind by reason of the grants contained in this treaty or by reasons of the operations of the United States, its agents or employees, or by reason of the construction, maintenance, operation, sanitation, and protection of the said Canal or of the works of sanitation and protection herein provided for, shall be appraised and settled by a joint Conmission appointed by the Governments of the United States and the Republic of Panama, whose decisions as to such damages shall be final and whose awards as to such damages shall be paid solely by the United States. No part of the work on said Canal or the Panama Railroad or on any auxiliary works relating thereto and authorized by the terms of this treaty shall be prevented, delayed or impeded by or pending such proceedings to ascertain such damages. The appraisal of said private lands and private property and the assessment of damages to them shall be based upon their value before the date of this convention.

\section{ArTICLE VII.}

The Republic of Panama grants to the United States within the limits of the cities of Panama and Colon and their adjacent harbors and within the territory adjacent thereto the right to acquire by purchase or by the exercise of the 


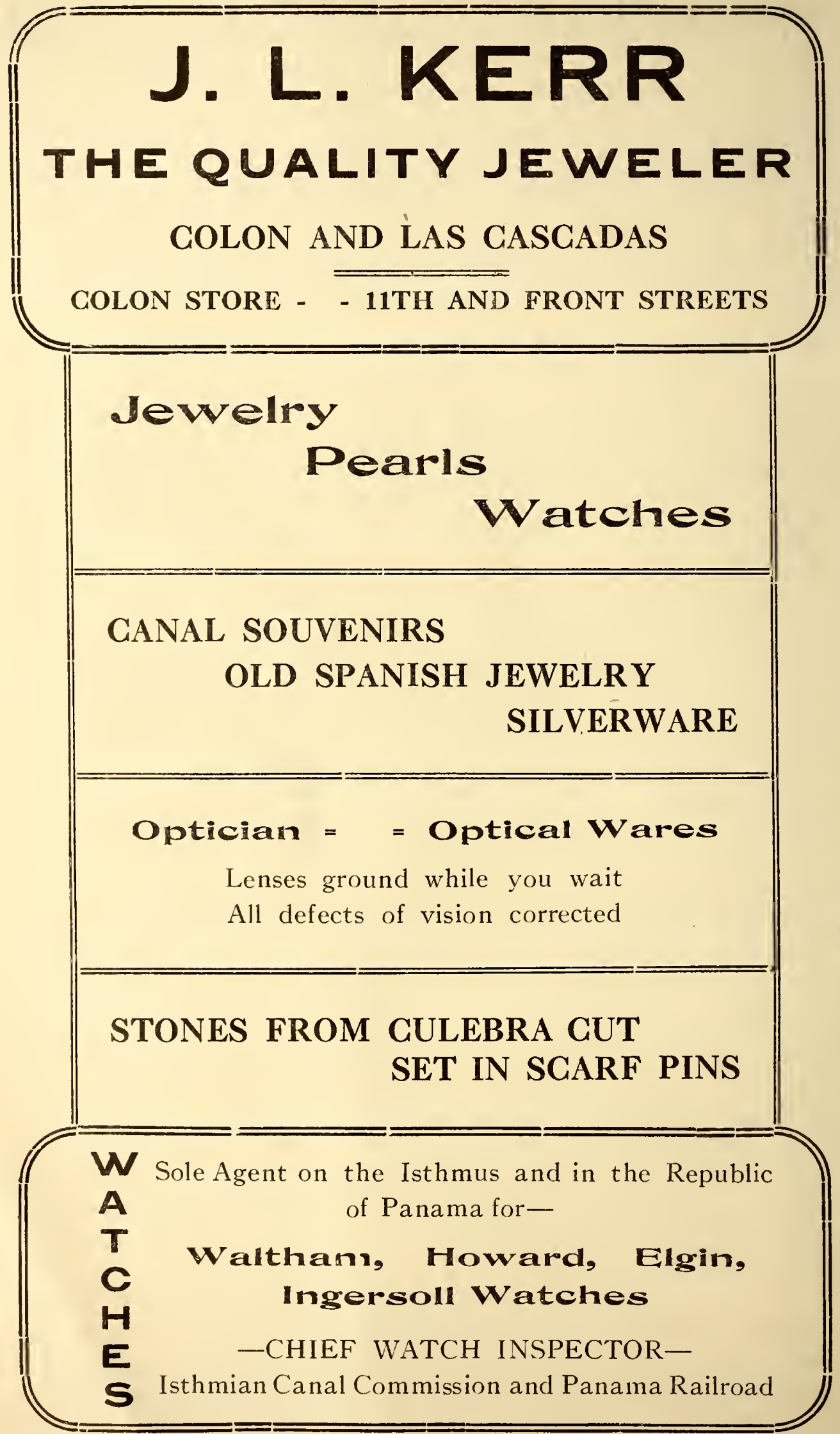


Isn't it great to know of a place where you can get your shoes repaired at moderate prices?

\section{THE PAN-AMERICAAN SHOE FACTORIY}

O1 Bottle Al1ey, Colon,

CORNER OF 8th ST. AND REAR OF THE COLONEL'S HOTEL

We can make practically a new shoe out of an old one, because we have up-to date Champion IIachinery to perform the work. We use the best White Oak imported leathers and employ only skilled labor. Above all we can ltt rou have vour shoes the same day you bring them. You have not got to wait three or four days fol them. We can repair your shoes while you wait. Te have splendid accommodations. Take a seat and pick up a paper and be comf lptable, and in 25 minutes you will have your shoes hall-soled and heeled, because we have machinery to perform the wolk. $^{\circ}$.

SATISFACTION GUARANTEED

right of eminent domain, any lands, buildings, water rights, or other properties necessary and convenient for the construction, maintenance, operation, and protection of the Canal and of any works of sanitation, such as the collection and disposition of sewage and the distribution of water in said cities of Panama and Colon, which, in the discretion of the United States may be necessary and convenient for the construction, maintenance, operation, sanitation, and protection of the said Canal and railroad. All such works of sanitation, collection and disposition of sewage and distribution of water in the cities of Panama and Golon shall be made at the expense of the United States, and the Government of the United States, its agents or nominees shall be authorized to impose and collect water rates and sewage rates which shall be sufficient to provide for the payment of interest on the amortization of the principal of the cost of said works within a period of fifty years and upon the expiration of said term of fifty years the system of sewers and water works shall revert to and become the properties of the cities of Panama and Colon respectively, and the use of the water shall be free to the inhabitants of Panama and Colon, except to the extent that water rates may be necessary for the operation and maintenance of said system of sewers and water.

The Republic of Panama agrees that the cities of Panama and Colon shall comply in perpetuity with the sanitary ordinances whether of a preventive or curative character prescribed by the United States and in case the Government of Panama is unable or fails in its duty to enforce this compliance by the cities of Panama and Colon with the sanitary ordinances of the United States the Republic of 


\section{THE CITY PHOTO STUDIO}

The Leading Photographic Studio in Colon

PATRONIZED BY ALL THE AMERICANS ON THE ISTHMUS

24 FRONT STREET, COLON, R. P. TWO DOORS SOUTH OF INTERNATIONAL BANKING CO.

Portraits, Groups,

Enlargements, Views

and Post Cards

LANTERN SLIDES OF THE CANAL

\section{PORTRAITS OF INFANTS--A Specialty}

DEVELOPING AND

PRINTING FOR AMATEURS, RIGHT AND QUICK

SHORT ORDERS EXECUTED PROMPTLY FOR TOURISTS

M. ALEX. RICMARDS, 


\section{Before You Leave Colon}

VISIM

\section{TrotT's Novelty Shop}

Post Cards

Soubenirs of all kinds

Natibe Curios

Periodicals

Stationery

Candies

33 FRONT STREET - - - - COLON

OPPOSITE P. R. R. STATION

Panama grants to the United States the right and authority to enforce the same.

The same right and authority are granted to the United States for the maintenance of public order in the cities of Panama and Colon and the territories and harbors adjacent thereto in case the Republic of Panama should not be, in the judgment of the United States, able to maintain such order.

\section{Article VIII.}

The Republic of Panama grants to the United States all rights which it now has or hereafter may acquire to the property of the New Panama Canal Company and the Panama Railroad.Company as a result of the transfer of sovereignty from the Republic of Colombia to the Republic of Panama over the Isthmus of Panama and authorizes the New Panama Canal Company to sell and transfer to the United States its rights, privileges, properties, and concessions as well as the Panama Railroad and all the shares or part of the shares of that company; but the public lands situated outside of the Zone described in Article II of this treaty now included in the concessions to both said enterprises and not required 





in the construction and operation of the Canal shall revert to the Republic of Panama except any property now owned by or in the possession of said companies within Panama or Colon or the ports or terminals thereof.

ARTICLE IX.

The United States agrees that the ports at either entrance of the Canal and the waters: thereof, and the Republic of Panama agrees that the itowns of Panama and Colon shall be free for all time.so that there shall not be imposed or collected custom house tolls; tonnage, anchorage, light-house, wharf, pilot, or quarantine dues or any other charges or taxes of any kind upon any vessel using or passing through the Canal or belonging to or employed by the United States, directly or indirectly, in connection with the construction, maintenance, operation, sanitation, and protection of the main Canal, or auxiliary works, or upon the cargo, officers, crew or passengers of any such vessels, except such tolls and charges as may be imposed by the United States for the use of the Canal and other works, and except tolls and charges imposed by the Republic of Panama upon merchandise destined to be introduced for the consumption of the rest of the Republic of Panama, and upon vessels touching at

\section{Pepuvian
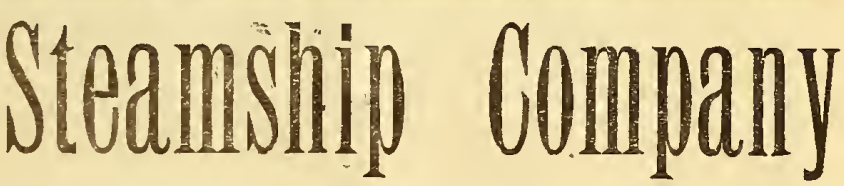

Five New Magnificent Steamers

UCAYALI

- MANTARO - URUBAMBBA PACHITEA - HUALLAGA

Excellent accommodations for First and Second Class Passengers. Third-Class accommodations also. All of our steamers are equipped with Marconi wireless and carry a complete equipment of life-saving apparatus and lifeboats as required by the U. S. Government Inspectors. Weekly sailings from Panama for CALLAO calling at Payta, Eten, Pacasmayo, Salaverry, and Mollendo. Fortnight!y sailings for 'GUAYAQUIL.

\section{Compania Peruna de Vapores y Dique del Callao GEORGE SHARPE, General Manager, Lima, Peru EDUARDO HIGGINSOR,; Agent 25 Ercad.St. N.Y. \\ E. AYULO \& Co., Agents} P: L. FELLINGER, Agent, Panáma 


\section{NATIONAL NAVIGATION COMPANY \\ 5 PANAMA \\ S Darien ${ }^{-\mathrm{TO}-}$ \\ E David \\ A Aguadulce \\ M Chitre \\ E Puerto Mutis \\ R -AND- \\ S All Coast Ports}

TRIPS TO THE INTERIOR

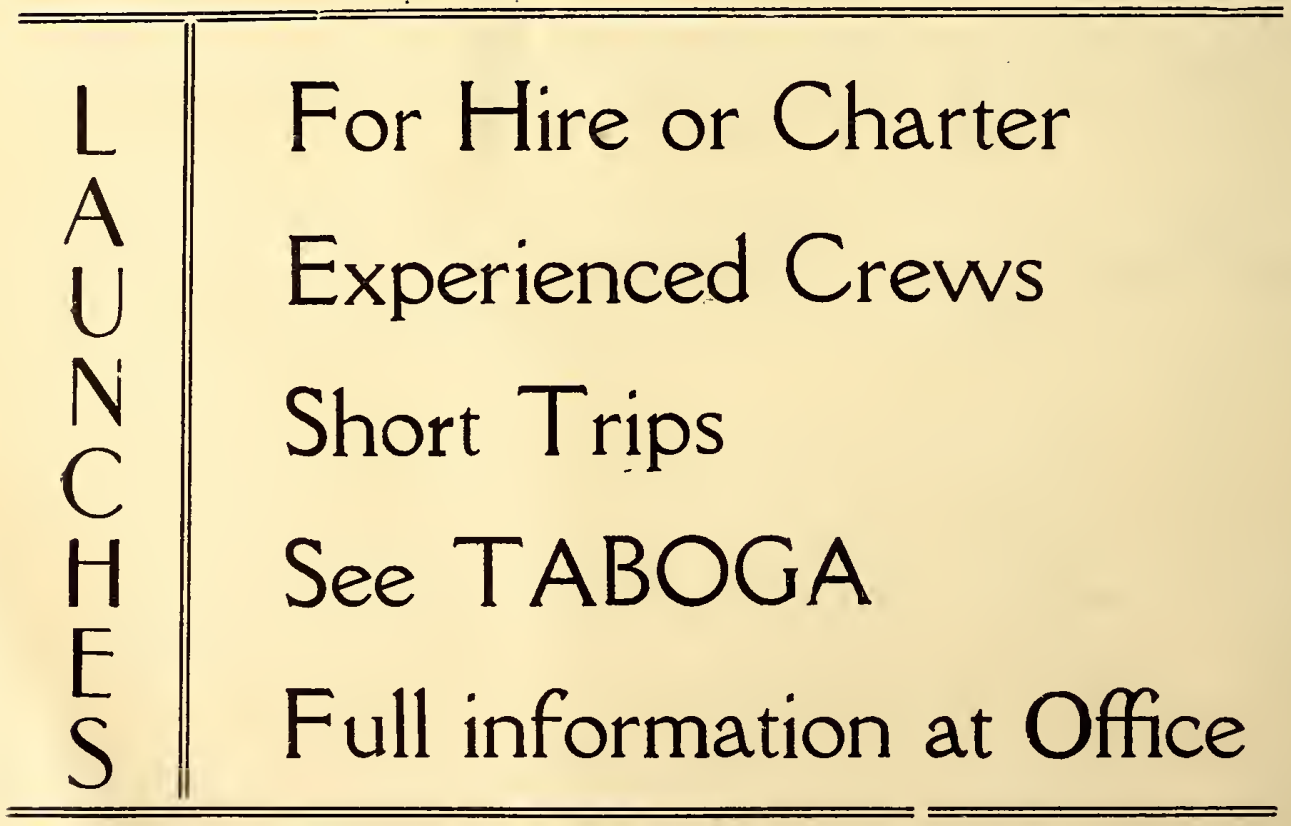

NATIONAL NAVIGATION COMPANY

AVENIDA NORTE NEAR PRESIDENCIA. 
the ports of Colon and Panama and which do not cross the Canal.

The Government of the Republic of Panama shall have the right to establish in such ports and in the towns of Panama and Colon such houses and guards as it may deem necessary to collect duties on importations destined to other portions of Panama and to prevent contraband trade. The United States shall have the right to make use of the towns and harbors of Panama and Colon as places of anchorage, and for making repairs, for loading, unloading, depositing, or trans-shipping cargoes either in transit or destined for the service of the Canal and for other works pertaining to the Canal.

\section{Article X.}

The Republic of Panama agrees that there shall not be imposed any taxes, national, municipal, departmental, or of any other class, upon the Canal, the railways and auxiliary works, tugs, and other vessels employed in the service of the Canal, store houses, work shops, offices, quarters for laborers, factories of all kinds, warehouses, wharves, machinery, and other works, property, and effects appertaining to the Canal or railroad and auxiliary works, or their officers or employees, situated within the cities of Panama and Colon and that there shall not be imposed contributions or charges of a personal character of any kind upon officers, employees, laborers, and other individuals in the service of the Canal and railroad and auxiliary works.

\section{ARTICLE Xi.}

The United States agrees that the official dispatches of the Government of the Republic of Panama shall be transmitted over any telegraph and telephone lines established for Canal purposes and used for public and private business at rates not higher than those required from officials in the service of the United States.

\section{Article XII.}

The Government of the Republic of Panama shall permit the immigration and free access to the lands and workshops of the Canal and its auxiliary works of all employees and workmen of whatever nationality under contract to work upon or seeking employment upon or in anywise connected with the said Canal and its auxiliary works, with their respective families, and all such persons shall be free and exempt from the military service of the Republic of Panama. 


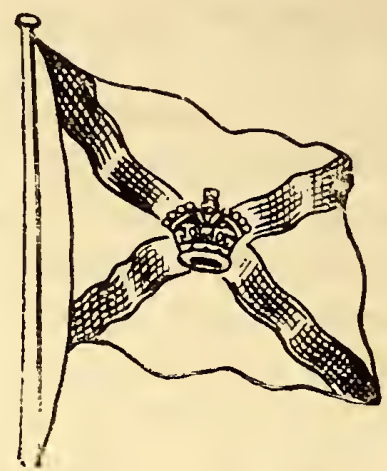

\section{The Royal Mail Steam Packet Company} (Royal Gharter Dated 1839)

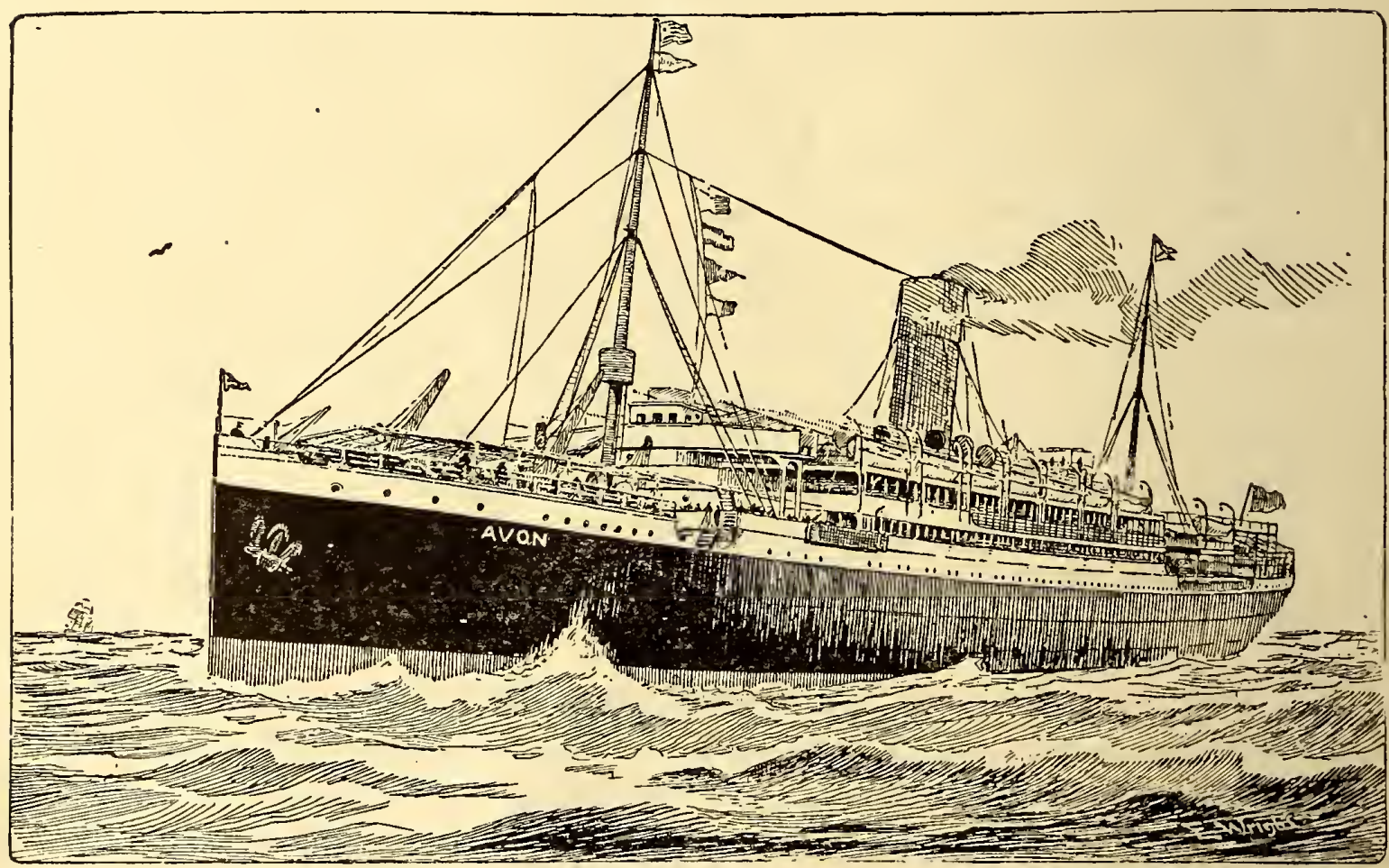

Services from ......

Colon to New York, via Jamaica and Cuba

every alternate Tuesday.

Colon to Cherbourg and Sou thampton, via

Cartagena Savanilla, Trinidad, and Barbados

New York to Bermuda, every Saturday.

every alternate Tuesday.

Services from London and Southampton to Brazil and River Plate, China, Japan, Australia, Spain, Portugal, Morocco, Mediterranean, Norway, etc.

For particular's apply to

THE ROYAL MAIL STEAM PACKET COMPANY, COLON. ISAAC BRANDON \& BROS., INC., PANAMA. 


\section{ArTICLE XIII.}

The United States may import at any time into the said zone and auxiliary lands, free of customs duties, imposts, taxes, or other charges, and without any restrictions, any and all vessels, dredges, engines, cars, machinery, tools, explosives, materials, supplies, and other articles necessary and convenient in the construction, maintenance, operation, sanitation, and protection of the Canal and auxiliary works, and all provisions, medicines, clothing, supplies, and other things necessary and convenient for the officers, employees, workmen and laborers in the service and employ of the United States and for their families. If any such articles are disposed of for use outside of the zone and auxiliary lands granted to the United States and within the territory of the Republic, they shall be subject to the same import or other duties as like articles imported under the laws of the Republic of Panama.

\section{ARTICLE XIV.}

As the price or compensation for the rights, powers and and privileges granted in this convention by the Republic of Panama to the United States, the Government of the United States agrees to pay to the Republic of Panama the sum of ten million dollars $(\$ 10,000,000)$ in gold coin of the United States on the exchange of the ratification of this convention and also an annual payment during life of this convention of two hundred and fifty thousand dollars $(\$ 250,000)$ in like gold coin, beginning nine years after the date aforesaid.

The provisions of this Article shall be in addition to all other benefits assured to the Republic of Panama under this convention.

But no delay or difference of opinion under this Article or any other provisions of this treaty shall effect or interrupt the full operation and effect of this convention in all other respects.

\section{ARTICLE XV.}

The joint commission referred to in Article VI shall be established as follows:

The President of the United States shall nominate two persons and the President of the Republic of Panama shall nominate two persons and they shall proceed to a decision; but in case of disagreement of the Commission (by reason of their being equally divided in conclusion) an Umpire shall 


\section{HAMBURG-AMERICANLINE}

383 Vessels - - Over 1,000,000 tons

Maintaining 68 Services Embracing the World

\section{FROM COLON, PANAMA}

To NEW YORK via JAMA ICA, B. W. I.-Weekly sailings

To CUBA (en route to New York)-Fortnightly sailings

'To COSTA RICA-Weekly sailings

These sailings are maintained by the Superb and Popular

"Prinz" steamers, of 5,500 tons, built especially for the tropics

\section{FROM COLON, PANAMA}

To GUATEMALA -Fortnightly sailings

To BOCAS DEL TORO (Panama)-Monthly sailings

To CARTAGENA AND SAVANILLA (Colombia)-Fortnightly sailings

To ST. THOMAS (Danish W. I.) -Fortnightly sailings

To HAVRE AND HAMBURG-Fortnightly sailings

These services maintained by fast freight and passenger steamers of 6,000 tons

For Particulars Apply to-

\section{HAMBURG-AMERICAN LINE}

COLON, R. P.

or to M. FIDANQUE \& SONS

6th ST., PANAMA 
be appointed by the two Governments who shall render the decision. In the event of the death, absence, or incapacity of a Commissioner or Umpire, or of his omitting, declining. or ceasing to act, his place shall be filled by the appointment of another person in the manner above indicated All decisions by a majority of the Commission or by the Umpire shall be final.

\section{ARTicle XVI.}

The two Governments shall make adequate provision by future agreement for the pursuit, capture, imprisonment, detention and delivery within said zone and auxiliary lands to the authorities of the Republic of Panama of persons charged with the commitment of crimes, felonies or misdemeanors without said zone and for the pursuit, capture, imprisonment, detention, and delivery without said zone to the authorities of the United States, of persons charged with the commitment of crimes, felonies, and misdemeanors. within said zone and auxiliary lands.

\section{Article XVII.}

The Republic of Panama grants to the United States the use of all the ports of the Republic open to commerce as places. of refuge for any vessels employed in the Canal enterprise, and for all vessels passing or bound to pass through the Canal which may be in distress and be driven to seek refuge in said ports. Such vessels shall be exempt from anchorage and tonnage dues on the part of the Republic of Panama.

\section{ArTICLE XVIII.}

The Canal when constructed, and the entrances thereto shall be neutral in perpetuity, and shall be open upon the terms provided for by Section I of Article three of, and in conformity with all the stipulations of, the treaty entered into by the Governments of the United States and Great Britian on November 18, 1901.

\section{ArticLE XIX.}

The Government of the Republic of Panama shall have the right to transport over the Canal its vessels and its troops and munitions of war in such vessels at all times without paying charges of any kind. The exemption is to be extended to the auxiliary railway for the transportation of persons. in the service of the Republic of Panama or of the police 


\section{Pacific Steam Navigation Company}

LARGE, FAST, COMFORTABLE STEAMERS EXCELLENT GUISINE

\section{For South Pacific:}

Every alternate Monday, connecting at Callao with the Strait Steamers' Rapid Service to principal West and East Coast ports and Europe.

These steamers' arrivals and sailings from Panama are arranged to connect with the Royal Mail Steam Packet Company's New York, Cuba, Jamaica, Colon, Service

\section{For Guayaquil Direct:}

Every 10 days with option of calling at intermediate ports

\section{For Guayaquil via Intermediate Ports:}

Every alternate Monday, calling at Colombian and Ecuadorian Ports

\section{For Colombian Ports Only:}

Every 14 days

THE PACIFIC STEAM NAVIGATION COMPANY, PATHEDRAL PLAZA THE ROYAL MAIL STEAM PACKET COMPANY, COLON 
force charged with the preservation of public order outside of said zone, as well as to their baggage, munitions of war and supplies.

\section{ARTICLE XX.}

If by virtue of any existing treaty in relation to the territory of the Isthmus of Panama, whereof the obligations shall descend or be assumed by the Republic of Panama, there may be any privilege or concession in favor of the Government or the citizens or subjects of a third power relative to an interoceanic means of communication which in any of of its terms may be incompatible with the terms of the present convention, the Republic of Panama agrees to cancel or modiify such treaty in due form, for which purpose it shall give to the said third power the requisite notification within the term of four months from the date of the present convention, and in case the existing treaty contains no clause permitting its modifications or annulment, the Republic of Panama agrees to procure its modifications or annulment in such form that there shall not exist any conflict with the stipulations of the present convention.

\section{Article XXI.}

The rights and privileges granted by the Republic of Panama to the United States in the preceding Articles are understood to be free of allanterior debts, liens, trusts, or liabilities, or concessions or privileges to other Governments, corporations, syndicates or individuals, and consequently, if there should arise any claims on account of the present concessions and privileges or otherwise, the claimants shall resort to the Government of the Republic of Panama and not to the United States for any indemnity or compromise which may be required.

\section{ARTICLE XXII.}

The Republic of Panama renounces and grants to the United States the participation to which it might be entitled in the future earnings of the Canal under Article XV of the concessionary contract with Lucien N. B. Wyse now owned by the New Panama Canal Company and any and all other rights or claims of a pecuniary nature arising under or relating to said concession, or arising under or relating to the concessions to the Panama Railroad Company or any extension or modification thereof; and it likewise renounces, confirms and grants to the United States, now and hereafter, all the rights and property reserved in the said consessions 


\section{FRENCH LINE OF MALL STEAMERS}

Fleet: 81 vessels - - Tonnage: 550,000 tons

\section{ATLANTIC LINES}

SAILINGS:

From COLON to CARTAGENA, PUERTO COLOMBIA, PUERTO CABELLO, LA GUAIRA, MARTINIQUE, GUADELOUPE and SAINT NAZAIRE, every 4 weeks.

From COLON to PORT LIMON, once every 4 weeks.

From COLON to PUERTO COLOMBIA, PUERTO CABELLO, LA GUIRA, CARUPANO, TRINIDAD, MARTINIQUE, GUADELOUPE, SANTANDER (Spain) and BORDEAUX every 4 weeks. 10 a. m.

From NEW YORK to HAVRE-PARIS, every Thursday at

From NEW YORK to HAVRE-PARIS, every Saturday at 3 p. m., for $2 \mathrm{~d}$ class passengers only.

Supplementary service from NEW YORK to HAVRE every 2 weeks.

From NEW YORK to BORDEAUX, monthly.

From PUERTO MEXICO and VFRA CRUZ to CUBA, SPAIN and EUROPE, on the 12th of each month.

From NEW ORLEANS to CUBA and EUROPE bi-monthly.

From HAI'TI to POR'TO RICO, SAIN'T THOMAS and EUROPE on the 13th of each month.

\section{MEDITERRANEAN LINES}

Daily departures from MARSEILIES to ALGERIA, TUNIS, SPAIN and MALTA.

Through tickets from NEW YORK to any of the above points in connection with the twin and quadruple-screw, NEW YORKHAVRE-PARIS service.

Any ship carries an experienced surgeon, stewardesses, interpreters. Cuisine the best, including wine free for all classes of passengers.

For further information apply to:

P. FAGU'ET, Gen'1. Agent, 19 State St., N. Y. City M. H. KOSMINSKY, 139 Dearborn St., Chicago FUGAZI BROS., 630 Mongomery St., San Francisco FIRST NATIONAL BANK, Pittsburg

A. L. POWELL, New York Avenue and 14th Street, Washington, D. C.

F. J. ORFILA, 213 Carondelet St., New Orleans

EHR MAN \& Co., Panama

GEO. SCHANG, Agent, Colon

and Agents of the Company at any of the above men tioned points. 
which otherwise would belong to Panama at or before the expiration of the terms of ninty-nine years of the concessions granted to or held by the above-mentioned party and companies, and all right, title and interest which it now has or may hereafter have, in and to the lands, canal, works, property and rights held by the said companies under said concessions or otherwise, and acquired or to be acquired by the United States from or through the New Panama Canal Company, including any property and rights which might or may in the future either by lapse of time, forfeiture or otherwise, revert to the Republic of Panama under any contracts or concessions, with said Wyse, the Universal Panama Canal Company, the Panama Railroad Company and the New Panama Canal Company.

The aforesaid rights and property shall be and are free and released from any present or reversionary interest or claims of Panama and the title of the United States thereto upon consummation of the contemplated purchase by the United States from the New Panama Canal Company, shall be absolute, so far as concerns the Republic of Panama, excepting always the rights of the Republic specifically secured under this treaty.

\section{ARTICLE XXIII.}

If it should become necessary at any time to employ armed forces for the safety or protection of the Canal, or of the ships that make use of the same, or the railways and auxiliary works, the United States shall have the right, at all times and in its descretion, to use its police and its land and naval forces or to establish fortifications for these purposes.

\section{ARTICLE XXIV.}

No change either in the Government or in the laws and treaties of the Republic of Panama shall, without the consent of the United States, affect any right of the United States under the present convention, or under any treaty stipulation between the two countries that now exists or may hereafter exist touching the subject matter of this convention.

If the Republic of Panama shall hereafter enter as a constituent into any other Government or into any union or confederation of states, so as to merge her sovereignty or independence in such Government, union or confederation, the rights of the United States under this convention shall no $t$ be in any respect lessened or impaired. 


\section{PANAMA

OFFICES:

NEW YORK GITY - :- COLON, R. P. 24 STATE STREET

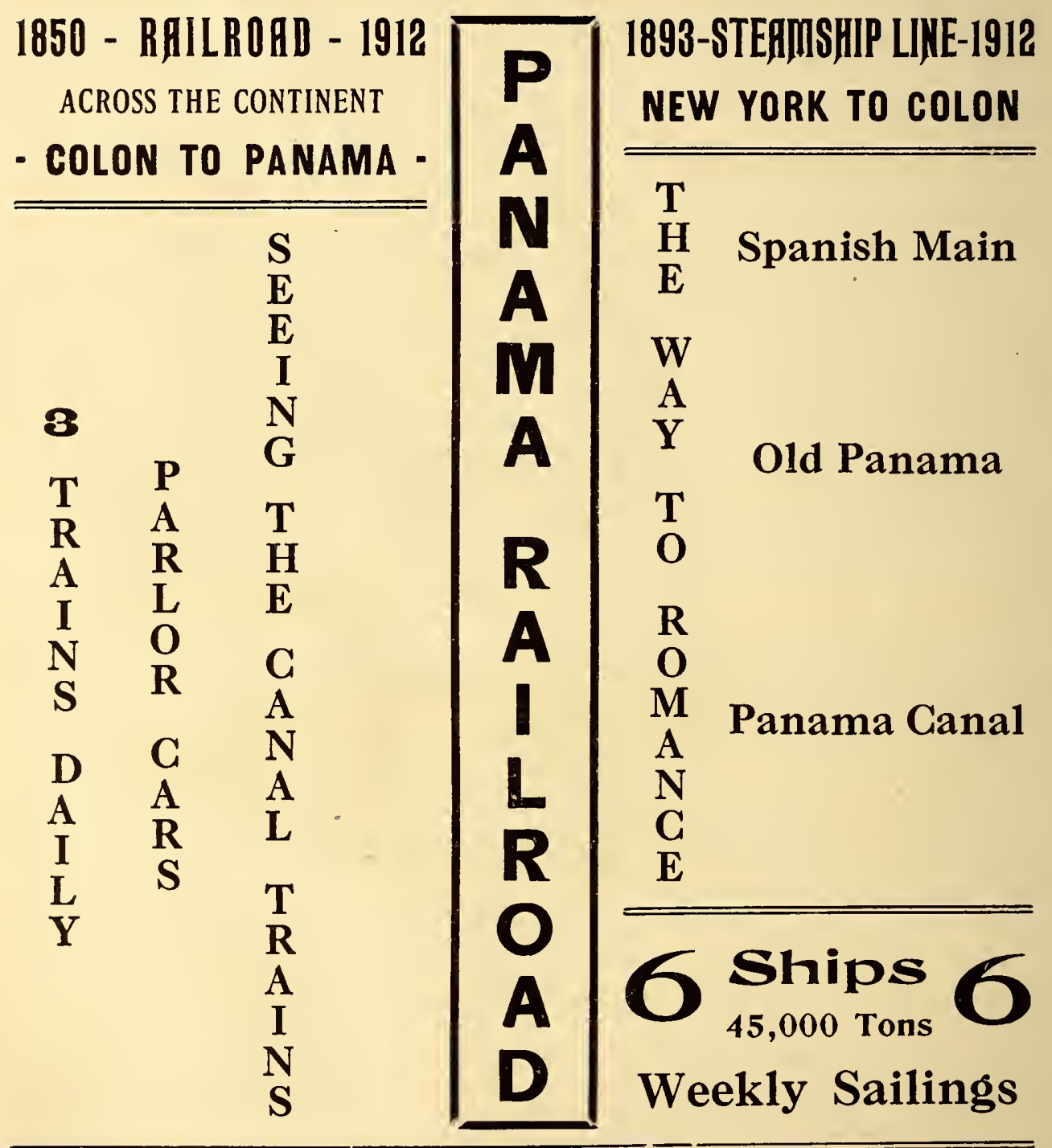

\section{WASHINGTON HOTEL}

OOLON

On the shore of Limon Bay-Cool the Year around 88 LARGE LEDROOMS $==$ FO0D UNEXCELLED

. Modern Concrete Hotel Open January, 1913. 


\section{ArticLe XXV.}

For the better performance of the engagements of this convention and to the end of the efficient protection of the Canal and the preservation of its neutrality, the Government of the Republic of Panama will sell or lease to the United States lands adequate and necessary for naval or coaling stations on the Pacific Coast and on the western Caribbean Coast of the Republic at certain points to be agreed upon with the President of the United States.

\section{ARTICLE XXVI.}

This convention when signed by the Plenipotentiaries of the Contracting Parties shall be ratified by the respective Governments and the ratifications shall be exchanged at Washington at the earliest date possible.

If faith whereof the respective Plenipotentiaries have signed the present convention in duplicate and have hereunto affixed their respective seals.

\section{The Locked=Wire Track Cable}

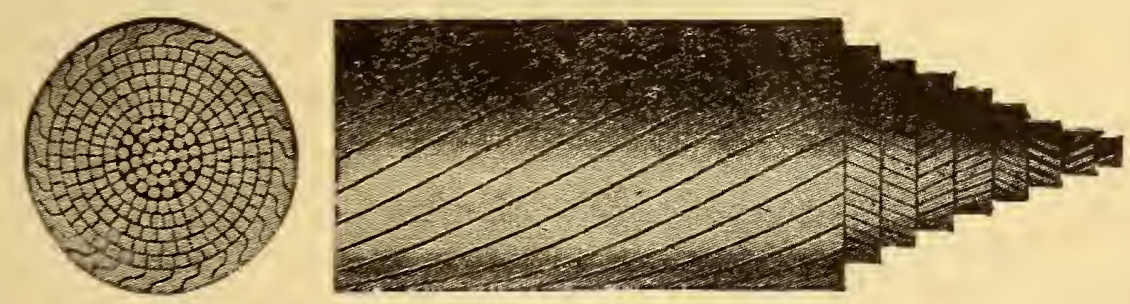

Only Cable With Smooth Surface

\section{Used on all the Cableways at Gatun}

\section{Wire Rope of All \\ Kinds. A erial Tram= \\ ways. Music Wire \\ MANUFACTURED BY \\ The Trenton Iron Company}

Trenton, N. J., and 30 Church St., New York

Americas Steel \& Wire Co. : Salt Lake City, Utah, and Denver, Colo.

United States Steel Products Co.: San Francisco, Cal., Los Angeles, Cal., Portland, Ore., Seattle, Wash., and Mexico City. 


\section{When Going to the States \\ MAKE THE TRIP VIA NEW ORLEANS}

And from thence over the Standard Road between the South acd the North-the

\section{Illinois Central R.R.}

Double daily fast electric-lighted train service from New Orleans, including the famous "Panama Limited," to

\section{Chícago : : : St. Louis Louisville : Cincinnati}

And to Points beyond, North, Northeast and Northwest

Through trains carry observation cars, drawing-room sleeping cars, dining cars, steel free reclining chair cars and steel coaches

\section{Write the undersigned for Information}

$\mathrm{He}$ will take p'easure in assisting you to plan your trip; will send complete itin. rary showing fares, schedules, stop-overs, hotel accommodations and illustrated descriptive advertising matter. He will also make sleeping car reservations for you. A representative of the Illinois Central will meet and a ssist you oa arrival at New Orleacs

W. H. Brill Asst. Gen. Pass. Agt., I. C. R. R., W. H. Brill, New Orleans, La. Illinois Central Offíce, 141 St. Charles St., 
Done at the City of Washington the 18th day of November in the year of our Lord nineteen hundred and three.

$$
\begin{array}{ll}
\text { JoHN HAY } & \text { [SEAL] } \\
\text { P. BUNAU-VARILLA } & \text { [SEAL] }
\end{array}
$$

And whereas the said Convention has been duly ratified on both parts, and the ratifications of the two governments were exchanged in the City of Washington, on the twentysixth day of February, one thousand nine hundred and four;

Now, therefore, be it known that I, Theodore Roosevelt, President of the United States of America, have caused the said Convention to be made public, to the end that the same and every article and clause thereof, may be observed and fulfilled with good faith by the United States and the citizens thereof.

In testimony whereof, I have hereunto set my hand and caused the seal of the United States of America to be affixed.

Done at the City of Washington, this twenty-sixth day of February, in the year of our Lord one thousand nine hundred and four, and of the Independence of the United States the one hundred and twenty-eighth.

[SEAL.] THEODORE ROOSEVELT.

By the President:

Johx HaY

Secretary of State. 


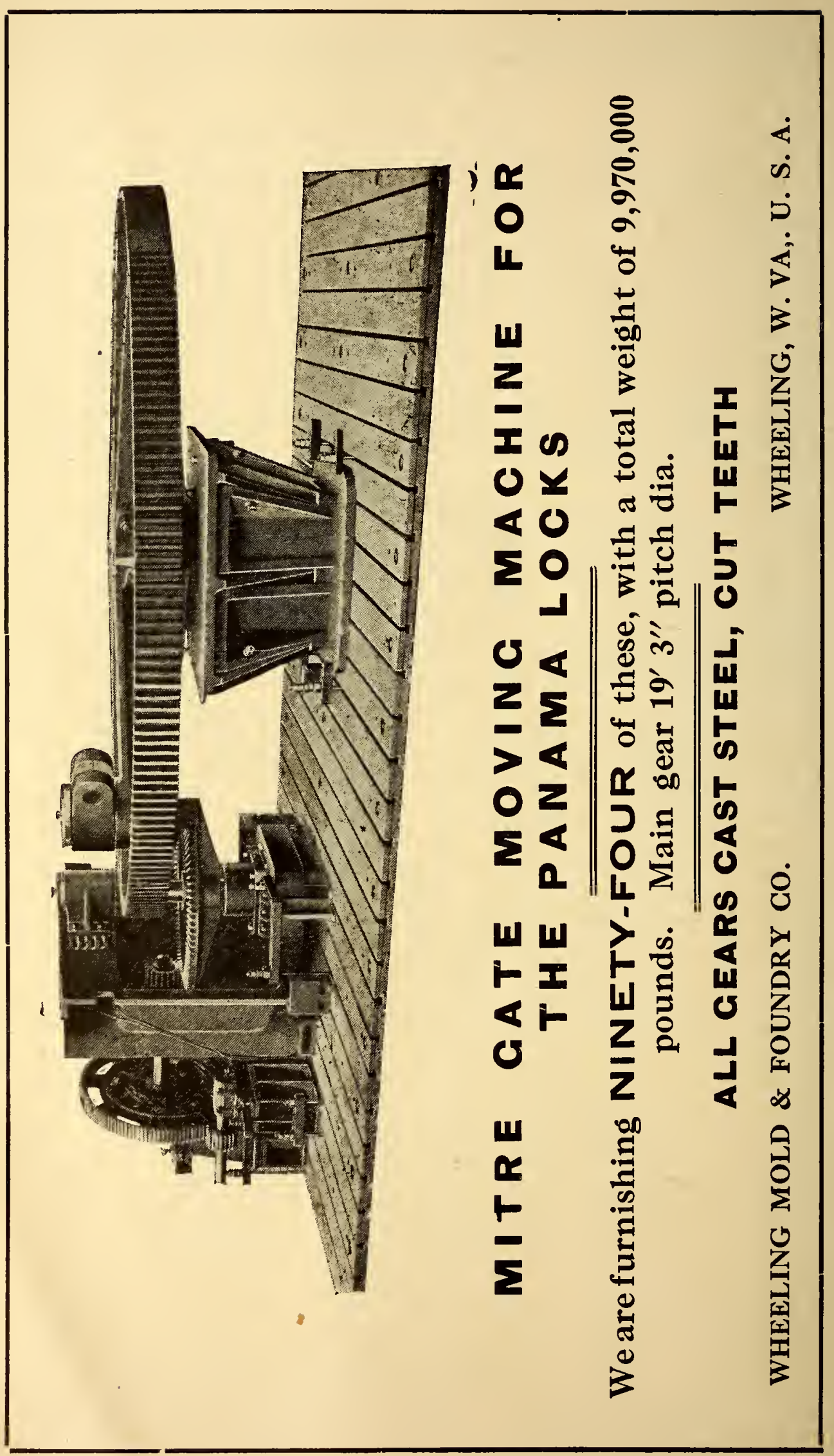




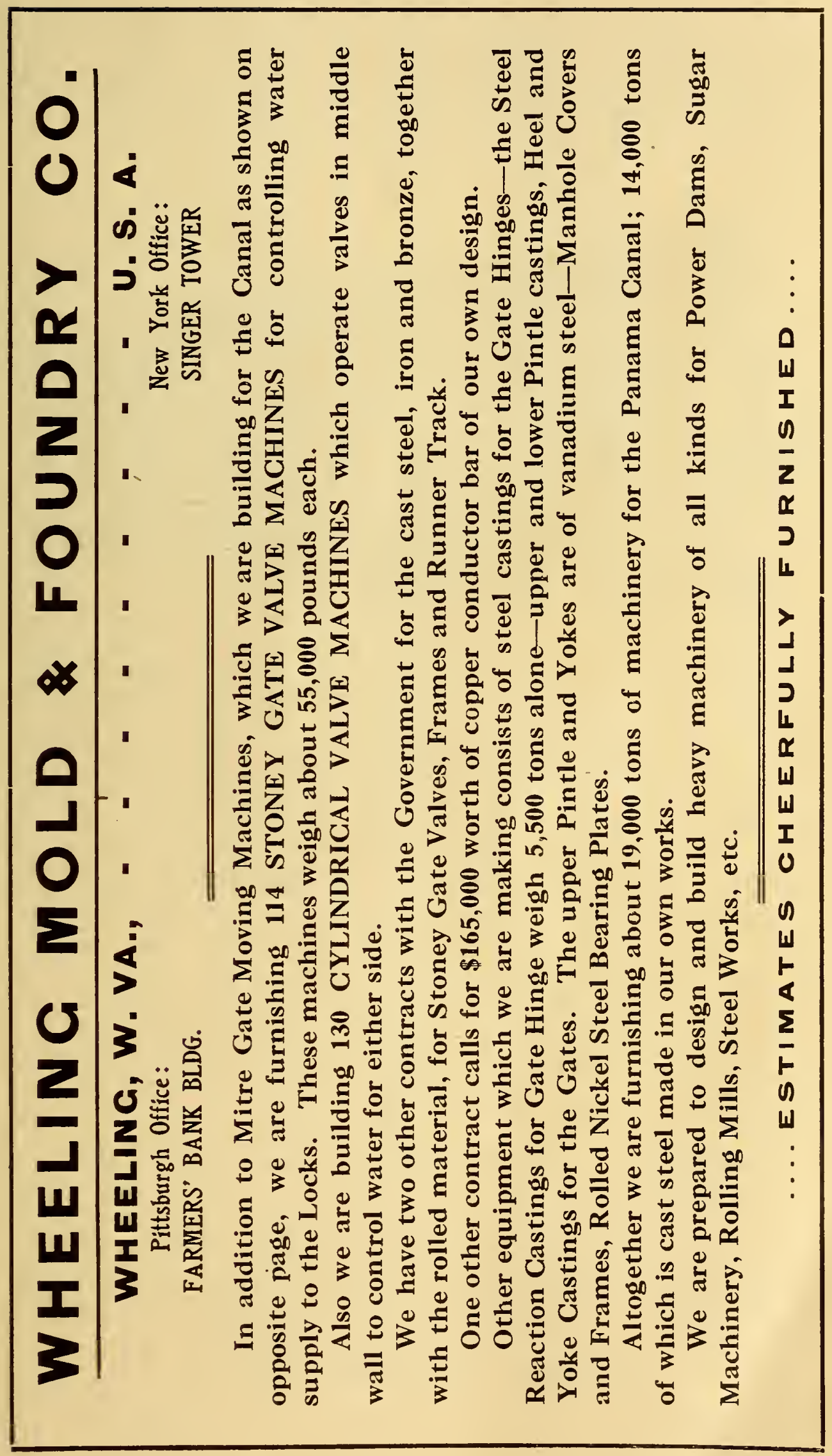




\section{THE WESTERN}

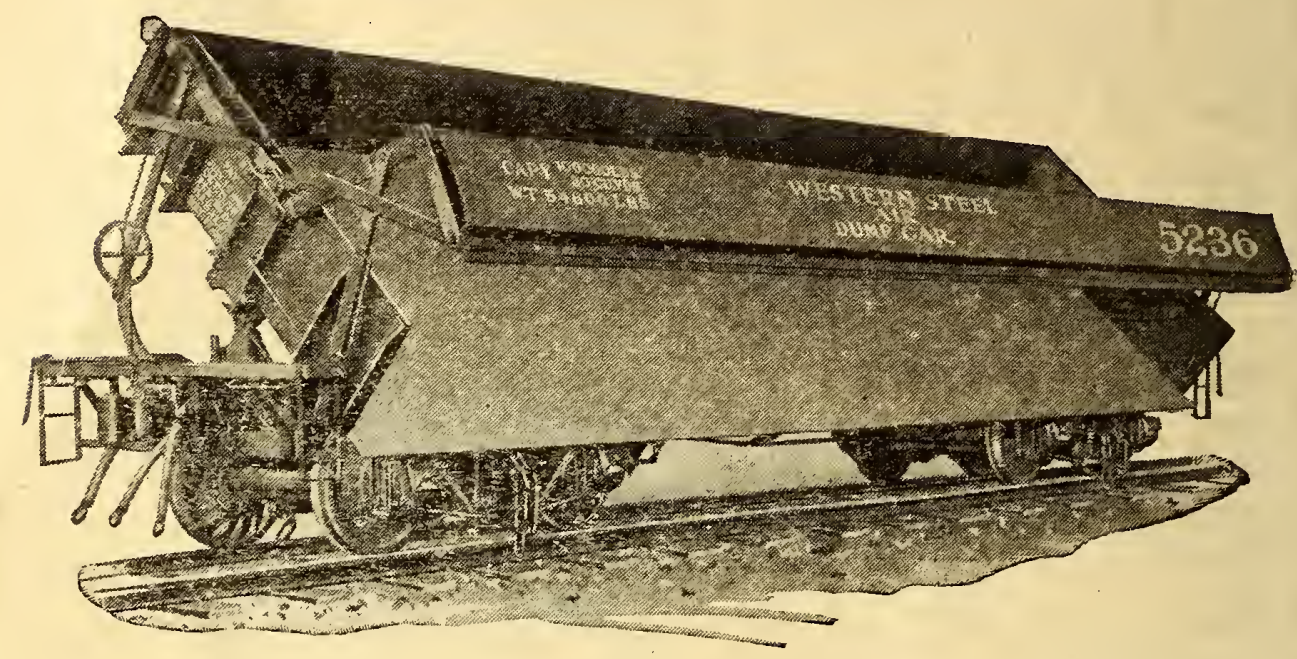

The wonderful work done by the WESTERN STEEL DUMP GARS in the excavation of the Culebra Cut and on other sections of the Canal is a part of the history of this worldrenowned enterprise. The cars are made to dump either by air operated by the Engineer or by hand. Can be dumped on either side, the side doors keing automatic. The cars are dumped and righted rapidly, stick to the track, are strong and durable, requiring few repairs. They are made in a variety of sizes from $1 \frac{1}{4}$ to 30 cubic yards capacity.

Full information on application

\section{WESTERN WHEELED SCRAPER COMPANY}

AURORA, ILLINOIS, U. S. A.

Cable Address:

WESTERN, AURORA. 


\section{Acts of Congress Affecting the Canal}

Spooner Act.

This act to provide for the construction of a canal connecting the waters of the Atlantic and Pacific oceans is the organic law of the Canal and Canal Zone.

Be it enacted by the Senate and House of Representatives of the United States of America in Congress assembled, That the President of the United States is hereby authorized to acquire, for and on behalf of the United States, at a cost not exceeding forty millions of dollars, the rights, privileges, concessions, grants of land, right of way, unfinished work, plants, and other property, real, personal, and mixed, of every name and nature, owned by the New Panama Canal Company, of France, on on the Isthmus of Panama, and all its maps, plans, drawings, records on the Isthmus of Panama and in Paris, including all the capital stock, not less, however,-than sixty-eight thousand eight hundred and sixty-three shares of the Pana-

\section{The Tourist's}

Companion

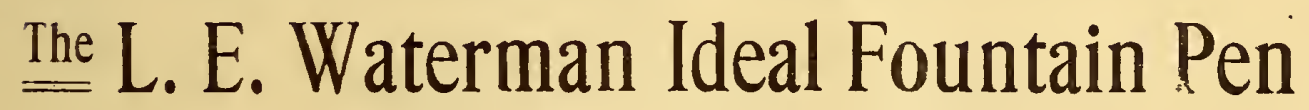

\section{FOR SALE BY \\ VIBERT \& DIXON}

Panama City $=$ Culebra $=$ Empire $=$ Gorgona $=$ Colon

Opposite Cathedral

Opposite P. R. R. Station

\section{The Business \\ Man's Partner}




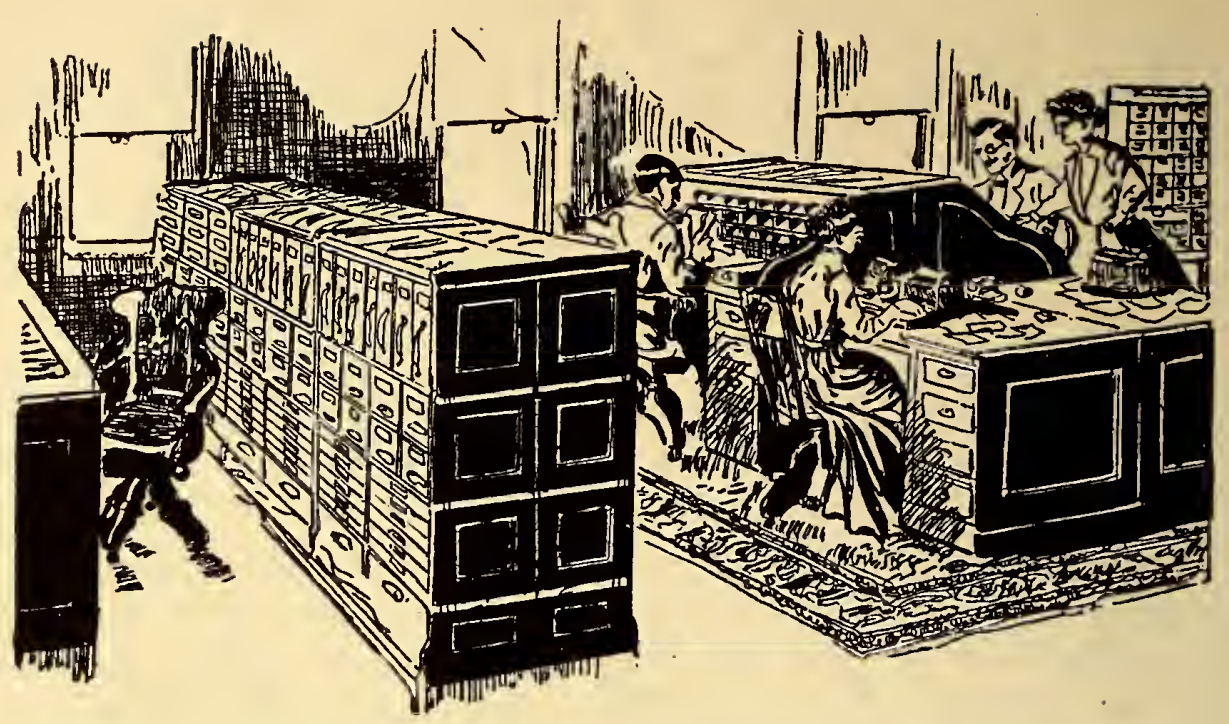

SEE IT HERE AND EVERYWHERE

Where big enterprises are being developed, where commerce thrives, where the work is directed by men of efficiency, there you find THE LAW OF STANDARDIZATION enforced.

It is the recognition of this law that accounts for the universal popularity of

\section{Slobe-Wernieke \\ WOOD AND STEEL}

\section{Filing Equipment}

wHCH IS THU BTTNDARD OF EXCELLENCE THE WORL OVE.

In the care of filing Important Papers, Contracts, Letters, Blue Prints, Leases, our Wood and Steel Filing Cabinets have been extensively used by the builders of the Panama Canal, because in addition to the service rendered they successfully stand the climatic conditions.

\section{The Slube-Wernicke Co. \\ CINOINNATI}

BRANCH STORES-NEW YORK, CHICAGO, PHILADELPHIA, WASHINGTON, AND BOSTON. 
ma Rail Road Company, owned by or held for the use of said Canal Company, provided a satisfactory title to all of said property can be obtained.

Sec. 2. That the President is hereby authorized to acquire from the Republic of Colombia, for and on behalf of the United States, upon such terms as he may deem reasonable, perpetual control of a strip of land, the territory of the Republic of Colombia, not less than six miles in width, extending from the Caribbean Sea to the Pacific Ocean, and the right to use and dispose of the waters thereon, and to excavate, construct and to perpetually maintain, operate, and protect thereon a Canal, of such depth and capacity as will afford convenient passage of ships of the greatest tonnage and draft now in use, from the Caribbean Sea to the Pacific Ocean, which control shall include the right to perpetually maintain and operate the Panama Railroad, if the ownership thereof, or a controlling interest therein, shall have been acquired by the United States, and also jurisdiction over said strip and the ports at the ends thereof to make

\section{Take a KODAK With You!}

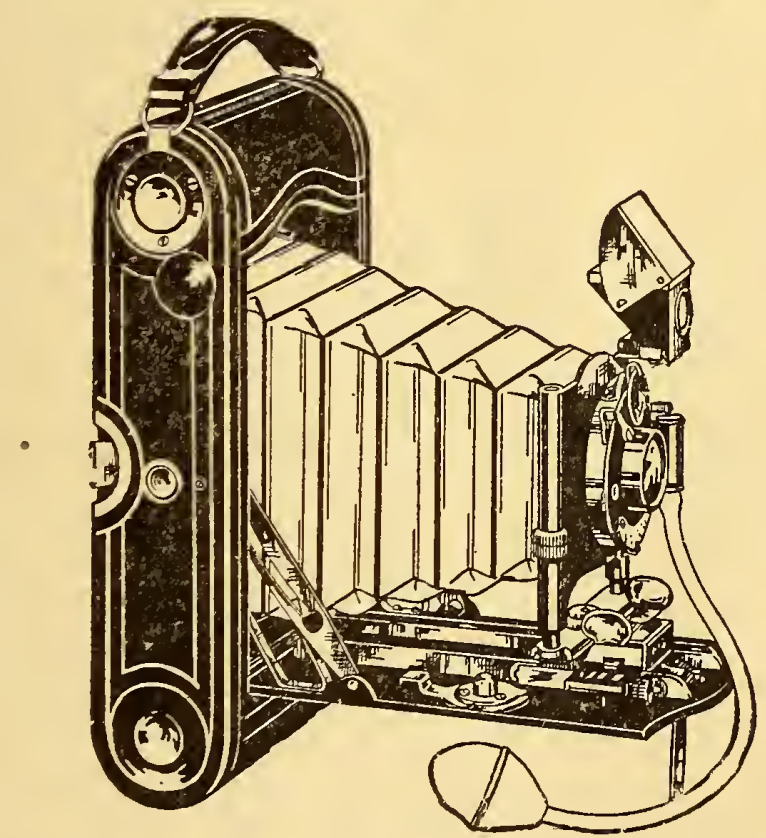

A Complete Supply of KODAK uUODS Alwảys in Stock
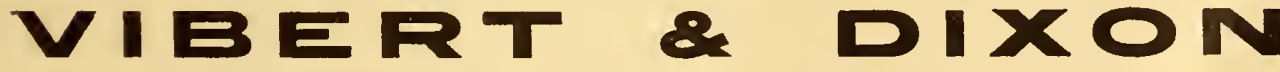

Developing Film and Printing on Velox a Specialty

Panama City : Culebra : Empire : Gorgona : Colon Opposite Cathedral

Opposite Station 


\title{
Keystone National Powder Company
}

\author{
EMPORIUM, PA.
}

\author{
Man- \\ ufacturers \\ of all kinds of
}

High Explosives

for Quarries, Mines of all

kinds, Railroad Construction,

etc. Capacity, 150,000 pounds per

day. We have furnished over Twenty

(20) Million pounds for the digging

of THE BIG DITCH across the

ISTHMUS and have a contract

for approximately Four

(4) Million pounds

for the balance

of the year

1912

For Efficiency of Our Goods-

Write us for Copy of CANAL RECORD of March 30, I9IO 
such police and sanitary rules and regulations as shall be necessary to preserve order and preserve the public helath thereon, and to establish such judicial tribunals as may be agreed upon thereon as may be necessary to enforce such rules and regulations.

The President may acquire such additional territory and rights from Colornbia as in his judgment will facilitate the general purpose hereof.

Sec. 3. That when the President shall have arranged to secure a satisfactory title to the property of the New Panama Canal Company, as provided in section one hereof, and shall have obtained by treaty control of the necessary territory from the Republic of Colombia, as provided in section two hereof, he is authorized to pay for the property of the New Panama Canal Company forty millions of dollars and to the Republic of Colombia such sum as shall have been agreed upon, and a sum sufficient for toth said purposes is hereby appropriated, out of any money in the Treasury not otherwise appropriated, to be paid on warrant or warrants drawn by the President.

\section{BUCYRUS COMPANY}

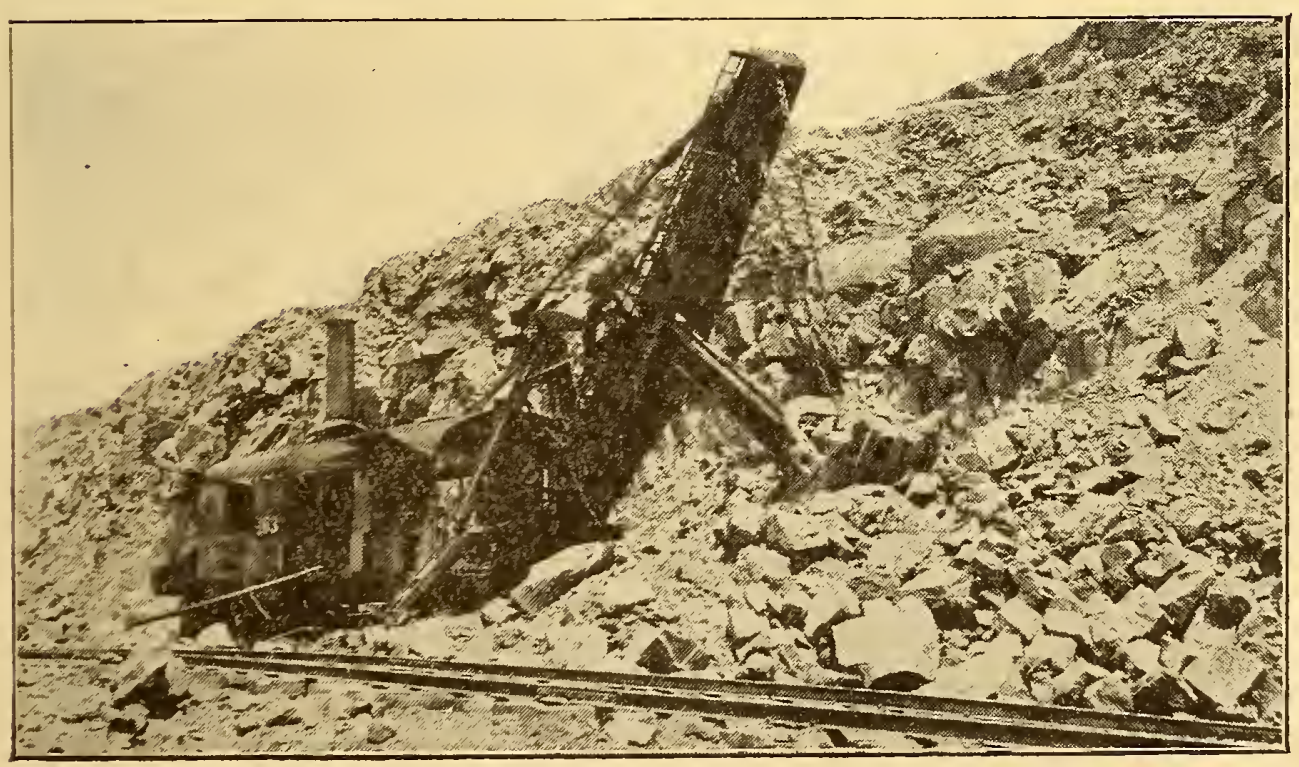

ONE OF THE 77 BUCYRUS SHOVELS UIGGING THE PANAMA CANAL

MANUFACTURERS OF

Steam, Electric and Gasoline Shovels of all sizes, Drag Line Excarators, River, Harbor, and ciold Dredges, Kailway Wrecking Cranes, Locomotive Pile Drivers and Inloating Plows.

MAIX OFFICE AND WORKS, SOUTH MILIVAUKEE, WISCONSIN 


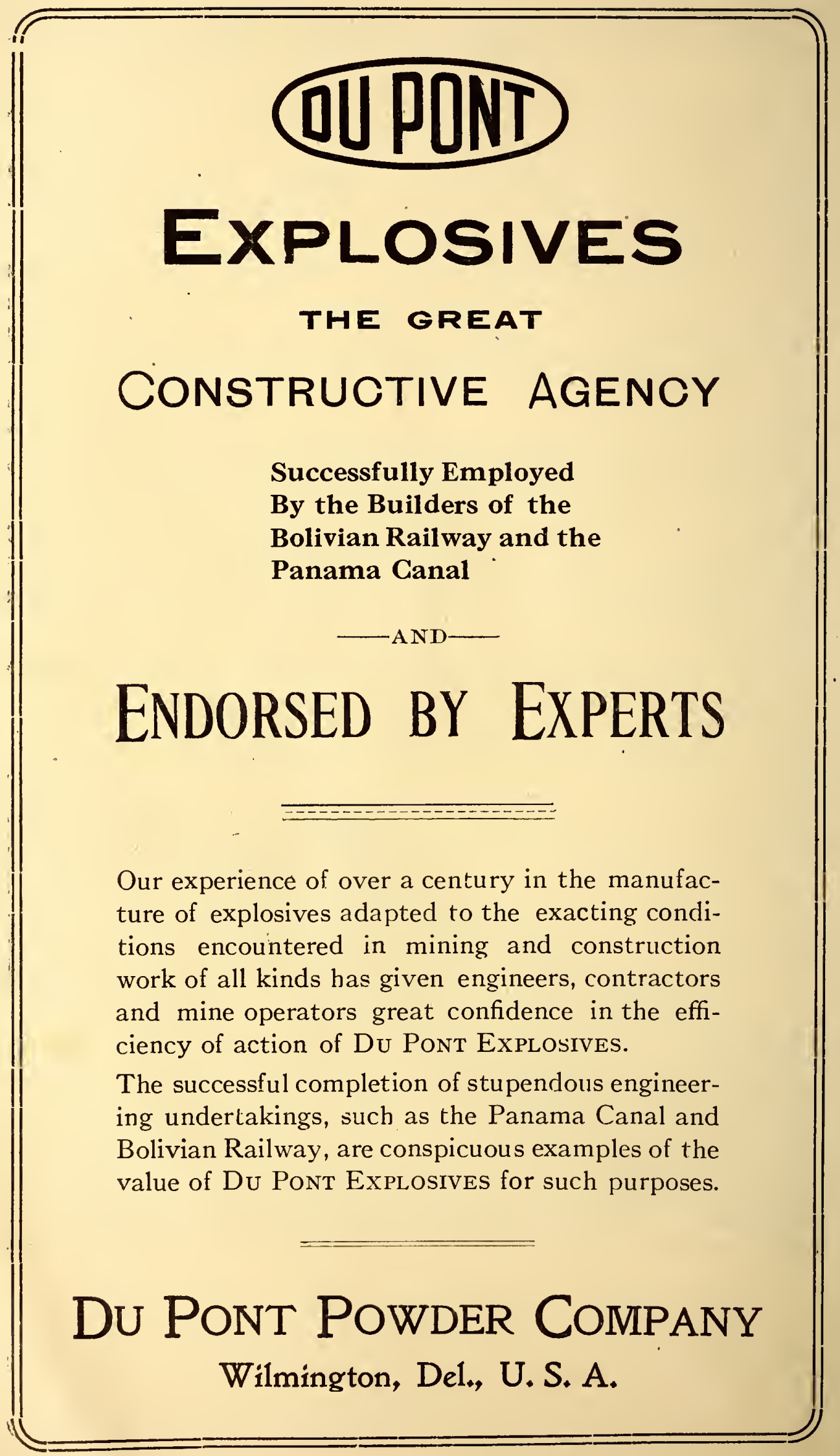


The President shall then through the Isthmian Canal Commission hereinafter authorized cause to be excavated, constructed, and completed, utilizing to that end as far as practicable the work heretofore done by the New Panama Canal Company, of France, and its predecessor company, a ship canal from the Caribbean Sea to the Pacific Ocean. Such canal shall be of sufficient capacity and depth as shall afford convenient passage for vessels of the largest tonnage and greatest draft now in use, and such as may be reasonably anticipated, and shall be supplied with all necessary locks. and other appliances to meet the necessities of vessels passing through the same from ocean to ocean; and he shall also cause to be constructed such safe and commodious harbors at the termini of said Canal, and make such provisions for defense as may be necessary for the safety and protection of said canal and harbors. That the President is authorized for the purposes aforesaid to employ such persons as he may deem necessary, and to fix their compensation.

Sec. 4. That should the President be unable to obtain for the United States a satisfactory title to the property of the New Panama Canal Company and the control of the necessary territory of the Republic of Colombia and the rights mentioned in sections one and two of this Act, within a reasonable time and upon reasonable terms, then the President, having first obtained for the United States perpetual control by the treaty of the necessary territory from Costa Rica and Nicaragua, upon terms which he may consider reasonable, for the construction, perpetual maintenance, operation, and protection of a canal connecting the Caribbean Sea with the Pacific Ocean by what is commonly known as the Nicaragua route, shall through the said Isthmian Canal Commission cause to be excavated and constructed a ship canal and waterway from a point on a shore of the Caribbean Sea near Greytown, by way of Lake Nicaragua, to a point near Brito on the Pacific Ocean. Said canal shall be of sufficient capacity and depth to afford convenient passage for vessels of the largest tonnage and greatest draft now in use, and such as may be reasonably anticipated, and shall be supplied with all necessary locks and other appliances to meet the necessities of vessels passing through the same from ocean to ocean; and he shall also construct such safe and commodious harbors at the termini of said canal as shall be necessary for the safe and convenient use thereof; and shall make such pro- 


\section{MOTORS}

that will stand up under tropical heat and humidity

For years we have been experimenting on INSULATION that will meet the severe atmospheric sonditions on the Isthmus of Panama. In an

\section{Open Competition}

in 1911 our Motors excelled all others and the Isthmian Canal Commission chose them for the

\section{Panama Canal Locks}

\section{GENERAL ELECTRIC COMPANY}

Schenectady, N.Y., U.S.A.

We have supplied for the Canal Two Million Dollars worth of Electrical Equipment including:

\section{Motors}

for the Locks and Spillways, with Motor-Starting Switchboards

40 Electric Locomotives for towing ships through the Locks

Three 2,000-kw. Turbines for the hydro-electric station at Gatun, with

Three 2,000-kw. Generators with auxiliaries, exciters, and switchboards

3 Controlling Switchboards and Indicators for the Locks

\section{Cables}

for power leads and controlling motors

Construction Plants

at Gatun and Miraflores, each with three 1,500-kw. Curtis steam turbines 
visions for defense as may be necessary for the safety and protection of said harbors and canal and such sum or sums of money as may be agreed upon by such treaty as compensation to be paid to Nicaragua and Costa Rica for the concessions and rights hereunder provided to be acquired by the United States, are hereby appropriated, out of any money in the Treasury not otherwise appropriated, to be paid on warrant or warrants drawn by the President.

The President shall cause the said Isthmian Canal Commission to make such surveys as may be necessary for said canal and harbors to be made, and in making such surveys and in the construction of said canal may employ such persons as he may deem necessary, and may fix their compensation.

In the excavation and construction of said canal the San Juan River and Lake Nicaragua, or such parts of each as may be made available, shall be used.

Sec. 5. That the sum of ten million dollars is hereby appropriated, out of any money in the Treasury not otherwise appropriated, toward the project herein contemplated by either route so selected.

And the President is hereby authorized to cause to be entered into such contract or contracts as may be deemed necessary for the proper excavation, construction, completion; and defense of such canal, harbors, and defenses, by the route finally determined upon under the provisions of this Act. Appropriations therefor shall from time to time be hereafter made, not to exceed in the aggregate the additional sum of one hundred and thirty-five millions of dollars should the Panama route be adopted, or one hundred and eighty millions of dollars should the Nicaragua route be adopted.

Sec. 6. That in any agreement with the Republic of Colombia, or with the States of Nicaragua and Costa Rica, The President is authorized to guarantee to said Republic or to said States the use of said canal and harbors, upon such terms as may be agreed upon, for all vessels owned by said States or by citizens thereof.

Sec. 7. That to enable the President to construct the canal and works appurtenant thereto as provided in this Act, there is hereby created the Isthmian Canal Commission, the same to be composed of seven members, who shall be nominated and appointed by the President, by and with the advice and consent of the Senate, and who shall serve 


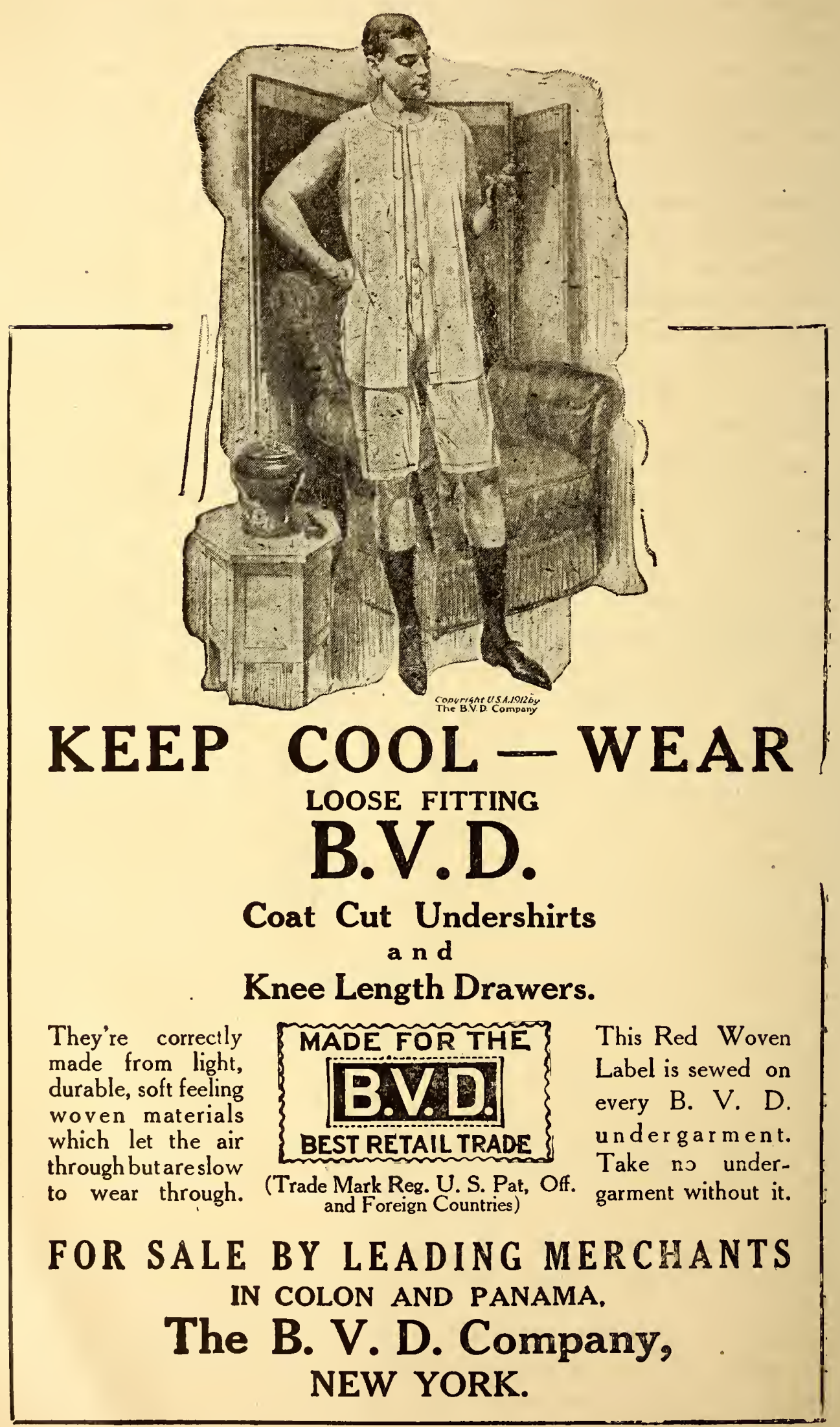


until the completion of said canal unless sooner removed by the President, and one of whom shall be named as the chairman of said Commission. Of the seven members of said Commission at least four of them shall be persons. learned and skilled in the science of engineering, and of the four at least one shall be an officer of the United States Army, and at least one other shall be an officer of the United States Navy, the said officers respectively being either upon the active or the retired list of the Army or of the Navy. Said commissioners shall each receive such compensation as the President shall prescribe until the same shall have been otherwise fixed by the Congress. In addition to the members of said Isthmian Canal Commission, the President is hereby authorized through said Commission to employ in said service any of the engineers of the United States Army at his discretion, and likewise to employ any engineers in civil life, at his discretion, and any other persons necessary for the proper and expeditious prosecution of said work. The compensation of all such engineers and other persons employed under this Act shall be fixed by said Commission, subject to the approval of the President. The official salary of any officer appointed or employed under this Act shall be deducted from the amount of salary or compensation provided by or which shall be fixed under the terms of this Act. Said Commission shall in all matters be subject to the direction and control of the President, and shall make to the President annually and at such other periods as may be required, either by law or by the order of the President, full and complete reports of all their actings and doings and of all moneys received and expended in the construction of said work and in the performance of their duties in connection therewith, which said reports shall be by the President transmitted to Congress. And the said Commission shall furthermore give to Congress, or either House of Congress, such information as may at any time be required either by Act of Congress or by the order of either House of Congress. The President shall cause to be provided and assigned for the use of the Commission such offices as may, with the suitable equipment of the same, be necessary and proper, in his discretion, for the proper discharge of the duties thereof.

Sec. 8. That the Secretary of the Treasury is hereby authorized to borrow on the credit of the United States from time to time, as the proceeds may be required to defray expenditures authorized by this Act (such proceeds 
ADVERTISEMENTS.

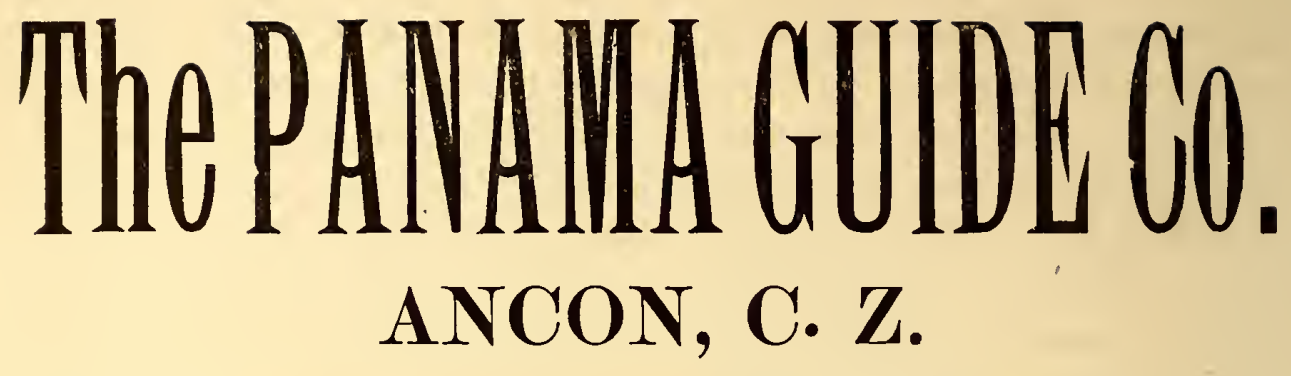

Of this edition of the book

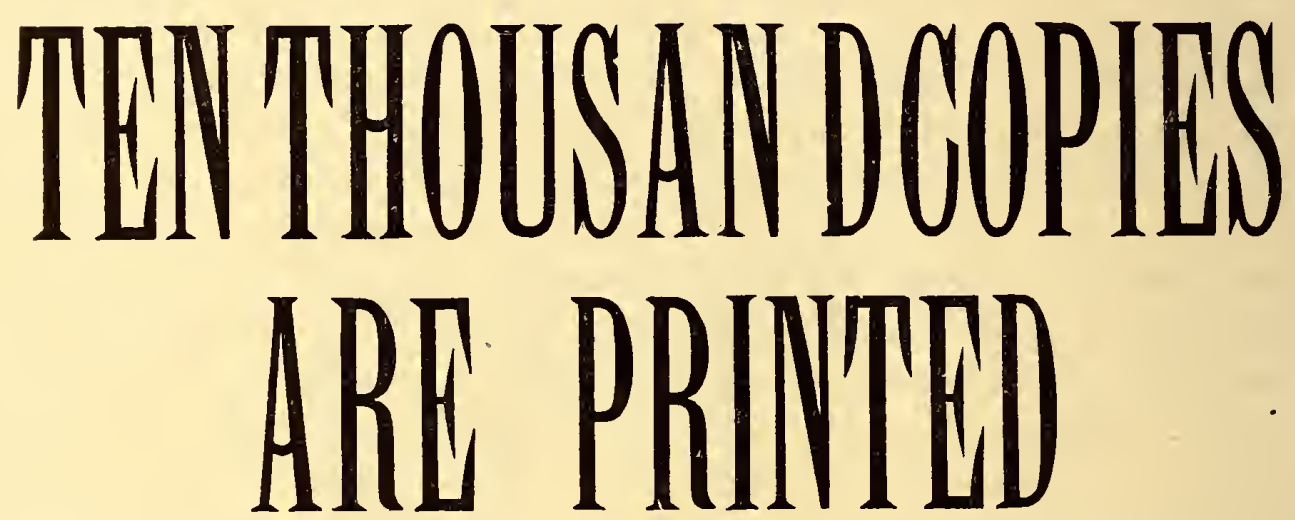

A Second Edition will be printed as soon as the present books are sold

\section{ADVERTISING SPACE RATES ON APPLICATION}

Address

JOHN O. COLLINS

ANCON, C. $Z$. 
when received to be used only for the purpose of meeting such expenditures,) the sum of one hundred and thirty million dollars, or so much thereof as may be necessary, and to prepare and issue therefor coupon or registered bonds of the United States in such form as he may prescribe, and in denominations of twenty dollars or some multiple of that sum, redeemable in gold coin at the pleasure of the United States after ten y ears from the date of their isssue, and payable thirty years from such date, and bearing interest payable quarterly in gold coin at the rate of two per centum per annum; and the bonds herein authorized shall be exempt from all taxes or duties of the United States, as well as from such taxation in any form by or under State, municipal, or local authority: Provided, That said bonds may be disposed of by the Secretary of the Treasury at not less than par, under such regulations as he may prescribe, giving to all citizens of the United States an equal opportunity to subscribe therefor, but no commissions shall be allowed or paid thereon; and a sum not exceeding one-tenth of one per centum of the amount of the bonds herein authorized is hereby appropriated, out of any money in the Treasury not otherwise appropriated, to pay the expense of preparing advertising, and issuing the same.

Approved, June 28, 1902. [32 U. S. Stats., 481.]

\section{Temporary Government of the Canal Zone.}

$B e$ it enacted by the Senate and House of Representatives of the United States of America in Congress assembled, That the President is hereby authorized, upon the acquisition of the property of the New Panama Canal Company and the payment to the Republic of Panama of the ten millions of dollars provided by article fourteen of the treaty between the United States and the Republic of Panama, the ratifications of which were exchanged on the twenty-sixth day of February, nineteen hundred and four, to be paid to the latter Government, to take possession of and occupy on behalf of the United States the zone of land and land under water of the width of ten miles, extending to the distance of five miles on each side of the center line of the route of the canal to be constructed thereon, which said zone begins in the Caribbean Sea three marine miles from mean low-water mark and extends to and across the Isthmus of Panama' in to the Pacific Ocean to the distance of three marine miles from nıean low-water mark, and also of all islands within said zone, and in addition thereto 
the group of islands in the Bay of Panama named Perico, Naos, Cullebra, and Flamenco, and, from time to time, of any lands and waters outside of said zone which may be necessary and convenient for the construction, maintenance, operation, sanitation, and protection of the said canal, or of any auxiliary canals or other works necessary and convenient for the construction, maintenance, operation, sanitation, and protection of said enterprise, the use, occupation, and control whereof were granted to the United States by article two of said treaty. The said zone is hereinafter referred to as "the Canal Zone." The payment of the ten millions of dollars provided by article fourteen of said treaty shall be made in lieu of the indefinite appropriation made in the third section of the Act of June twenty-eighth, nineteen hundred and two, and is hereby appropriated for said purpose.

Sec. 2. That until the expiration of the Fifty-eighth Congress, unless provision for the temporary government of the Canal Zone be sconer made by Congress, all the military, civil, and judicial powers as well as the power to make all rules and regulations necessary for the government of the Canal Zone and all the rights, powers, and authority granted by the terms of said treaty to the United States shall be vested in such person or persons and shall be exercised in such manner as the President shall direct for the government of said Zone and maintaining and protecting the inhabitants thereof in the free enjoyment of their liberty, property, and religion.

Approved, April 28, 1904. [33 U. S. Stats., 429.]

\section{Permanent Government for Panama Canal.}

Be it enacted by the $\dot{S}$ enate and House of Representatives of the United States of America in Congress assembled That the zone of land and land under water of the width of ten miles extending to the distance of five miles on each side of the center line of the routc of the Canal now being constructed thereon, which zone begins in the Caribbean Sea three marine miles from mean low water mark and extends to and across the Isthmus of Panama into the Pacific Ocean to the distance of three marine miles from mean low water mark, excluding therefrom the cities of Panama and Colon and their adjacent harbors located within said zone, as excepted in the treaty with the Republic of Panama dated November eighteenth, nineteen 
hundred and three, but including all islands within said described zone, and in addition thereto the group of islands in the Bay of Panama named Perico, Naos, Culebra, and Fla menco, and any lands and waters outside of said limits above described which are necessary or convenient or from time to time may become necessary or convenient for the construction maintenance, operation, sanitation, or protection of the said Canal, or of any auxiliary canals, lakes, or other works necessary or convenient for the construction, maintenance, operation, sanitation, or protection of said Canal, the use, occupancy, or control whereof were granted to the United States by the treaty between the United States and the Republic of Panama, the ratifications of which were exchanged on the twenty-sixth day of February, nineteen hundred and four, shall be known and designated as the Canal Zone, and the Canal now being constructed thereon shall hereafter be known and designated as the Panama Canal. The President is authorized by treaty with the Republic of Panama to acquire any additional land or land under water not already granted, or which was excepted from the grant, that he may deem necessary for the operation, maintenance, sanitation, or protection of the Panama Canal, and to exchange any land or land under water not deemed necessary for such purposes for other land, or land under water which may be deemed necessary for such purposes, which additional land or land under water so acquired shall become part of the Canal Zone.

Sec. 2. That all laws, orders, regulations, and ordinances adopted and promulgated in the Canal Zone by order of the President for the government and sanitation of the Canal Zone and the construction of the Panama Canal are hereby ratified and confirmed as valid and binding until Congress shall otherwise provide. The existing courts established in the Canal Zone by Executive Order are recognized and confirmed to continue in operation until the courts provided for in this Act shall be established.

Sec. 3. That the President is authorized to declare by Executive Order that all land and land under water within the limits of the Canal Zone is necessary for the construction, maintenance, operation, sanitation, or protection of the Panama Canal and to extinguish, by agreement when advisable, all claims and titles of adverse claimants and occupants. Upon failure to secure by agreement title to any such parcel of land or land under water the adverse claim or occupancy 
shall be disposed of and title thereto secured in the United States and compensation therefor fixed and paid in the manner provided in the aforesaid treaty with the Republic of Panama, or such modification of such treaty as may hereafter be made.

Sec. 4. That when in the judgment of the President the construction of the Panama Canal shall be sufficiently advanced toward completion to render the further services of the Isthmian Canal Commission unnecessary the President is authorized by Executive Order to discontinue the Isthmian Canal Commission, which, together with the present organization, shall then cease to exist; and the President is thereafter authorized to complete, govern, and operate the Panama Canal and govern the Canal Zone, or cause them to be completed, governed, and operated, through a governor of the Panama Canal and such other persons as he may deem competent to discharge the various duties connected with the completion, care, maintenance, sanitation, operation, government, and protection of the Canal and Canal Zone. If any of the persons appointed or employed as aforesaid shall be persons in the military or naval service of the United States, the amount of the official salary paid to any such perosn shall be deducted from the amount of salary or compensation provided by or which shall be fixed under the terms of this Act. The governor of the Panama Canal shall be appointed by the President, by and with the advice and consent of the Senate, commissioned for a term of four years, and until his successor shall be appointed and qualified. He shall receive a salary of ten thousand dollars a year. All other persons necessary for the completion, care, management, maintenance, sanitation, government, operation, and protection of the Panama Canal and Canal Zone shall be appointed by the President or by his authority, removable at his pleasure, and the compensation of such persons shall be fixed by the President, or by his authority, until such time as Congress may by law regulate the same, but salaries or compensation fixed hereunder by the President shall in no instance exceed by more than twentyfive per centum the salary or compensation paid for the same or similar services to persons employed by the Government in continental United States; that upon the completion of the Panama Canal the President shall cause the same to be officially and formally opened for use and operation. 
Before the completion of the Canal the Commission of Arts may make report to the President of their recommendation regarding the artistic character of the structures of the Canal, such report to be transmitted to Congress.

Sec. 5. That the President is hereby authorized to prescribe and from time to time change the tolls that shall be levied by the Government of the United States for the use of the Panama Canal: Provided, That no tolls, when prescribed as above, shall be changed, unless six months' notice thereof shall have been given by the President by proclamation. No tolls shall be levied upon vessels engaged in the coastwise trade of the United States. That section forty-one hundred and thirty-two of the Revised Statutes is hereby amended to read, as follows:

"Sec. 4132. Vessels built within the United States and belonging wholly to citizens thereof, and vessels which may be captured in war by citizens of the United States and lawfully condemned as prize, or which may be adjudged to be forfeited for a breach of the laws of the United States, and seagoing vessels, whether steam or sail, which have been certified by the Steamboat Inspection Service as safe to carry dry and perishable cargo, not more than five years old at the time they apply for registry, wherever built, which are to engage only in trade with foreign countries or with the Philippine Islands and the islands of Guam and Tutuila, being wholly owned by citizens of the Lnited States or corporations organized and chartered under the laws of the United States or of any State thereof, the president and managing directors of which shall be citizens of the United States or corporations organized and chartered under the laws of the United States or any state thereof, the president and managing directors of which shall be citizens of the United States, and no others, may be registered as directed in this title. Foreign built vessels registered pursuant to this Act shall not engage in the coastwise trade: Provided, That a foreign built yacht, pleasure boat, or vessel, not used or intended to be used for trade, admitted to American registry pursuant to this section, shall not be exempt from the collection of ad valorem duty provided in section thirty-seren of the Act approved August fifth, nineteen hundred ard nine, entitled 'An Act to rrovide revenue, equalize duties, and encourage the industries of the United States, and for cther purcoses.' That all materials of foreign production which may le necessary for the construction or repair of ressels built in the United States and all such materials 
necessary for the building or repair of their machinery, and all articles necessary for their outfit and equipment may be imported into the United States free of du ty under such regulations as the Secretary of the Treasury may prescribe: Provided further, That such vessels so admitted under the provisions of this section may contract with the Postmaster General, under the Act of March third, eighteen hundred and ninetyone, entitled 'An act to provide for ocean mail service between the United States and foreign ports, and to promote commerce,' so long as such vessels shall in all respects comply with the provisions and requirements of said Act." Tolls may be based upon gross or net registered tonnage, displacement tonnage, or otherwise, and may be based on one form of tonnage for warships and another for ships of commerce. The rate of tolls may be lower upon vessels in ballast than upon vessels carrying passengers or cargo. When based upon net registered tonnage for ships of commerce, the tolls shall not exceed one dollar and twenty-five cents per net registered ton, nor be less, other than for vessels of the United States and its citizens, than the estimated proportionate cost of the actual maintenance and operation of the Canal, subject, however, to the provisions of article nineteen of the convention between the United States and the Republic of Panama, entered into November eighteenth, nineteen hundred and three. If the tolls shall not be based upon net registered tonnage, they shall not exceed the equivalent of one dollar and twentyfive cents per net registered ton as nearly as the same may be determined, nor be less than the equivalent of seventy-five cents per net registered ton. The toll for each passenger shall not be more than one dollar and fifty cents. The President is authorized to make, and from time to time amend, regulations governing the operation of the Panama Canal, and the passage and control of vessels through the same or any part thereof, including the locks and approaches thereto, and all rules and regulations affecting pilots and pilotage in the Canal or the approaches thereto through the adjacent waters.

Such regulations shall provide for prompt adjustment by agreement and immediate payment of claims for damages which may arise from injury to vessels, cargo, or passengers from the passing of vessels through the locks under the control of those operating them under such rules and regulations. In case of disagreement, suit may be brought in the district court of the Canal Zone against the governor of the Panama Canal. The hearing and disposition of such cases shall be 
expedited, and the judgment shall be immediately paid out of any moneys appropriated or allotted for Canal operation.

The President shall provide a method for the determination and adjustment of all claims arising out of personal injuries to employees thereafter occurring while directly engaged in actual work in connection with the construction, maintenance, operation, or sanitation of the Canal or of the Panama railroad, or of any auxiliary canals, locks, or other works necessary and convenient for the construction, maintenance, operation or sanitation of the Canal, whether such injuries result in death or not, and prescribe a schedule of compensation therefor, and may revise and modify such method and schedule at any time; and such claims to the extent they shall be allowed on such adjustment if allowed at all, shall be paid out of the moneys hereafter appropriated for that purpose or out of the funds of the Panama Rail Road Company, if said company was responsible for said injury, as the case may require. And after such method and schedule shall be provided by the President the provisions of the Act entitled 'An Act granting to certain employees of the United States the right to receive frcm it compensation for injuries sustained in the course of their employment,' approved May thirtieth, nineteen hundred and eight, and of the Act entitled 'An Act relating to injured employees on the Isthmian Canal,' approved February twenty-fourth, nine. teen hundred and nine, shall not apply to personal injuries thereafter received and claims for which are subject to de. termination and adjustment as provided in this section.',

Sec. 6. That the President is authorized to cause to be erected, maintained, and operated, subject to the international convention and the Act of Congress to regulate radio communication, at suitable places along the Panama Canal and the coast adjacent to its two terminals, in connection with the operation of said Canal, such wireless telegraphic installations as he may deem necessary for the operation, maintenance, sanitation, and protection of said Canal, and for other purposes. If it is found necessary to locate such installations upon territory of the Republic of Panama, the President is authorized to make such agreement with said Government as may be necessary, and also to provide for the acceptance and transmission, by said system, of all private and commercial messages, and those of the Government of Panama, on such terms and for such tolls as the President 
may prescribe: Provided, That the messages of the Government of the United States and the departments thereof, and the management of the Panama Canal, shall always be given precedence over all other messages. The President is also authorized, in his discretion, to enter into such opera ting agreements or leases with any private wireless company or companies as may best insure freedom from interference with the wireless telegraphic installations established by the United States. The President is also authorized to establish, maintain, and operate, through the Panama Rail Road Comfany or otherwise, drydocks, repair shops, yards, docks, wharves, warehouses, storehouses, and other necessary facilities and appurtenances for the purfose of providing coal and other materials, labor, repairs, and supplies for vessels of the Government of the United States and incidentally, for supplying such at reasonable prices to passing vessels, in accordance with appropriations hereby authorized to be made from time to time by Congress as a part of the maintenance and operation of the said Canal. Moneys received from the conduct of said business may be expended and reinvested for such purposes without being covered into the Treasury of the United States; and such moneys are hereby appropriated for such purposes, but all deposits of such funds shall be subject to the provisions of existing law relating to the deposit of other public funds of the United States, and any net profits accruing from such business shall annually be covered into the Treasury of the United States. Monthly reports of such receipts and expenditures shall be made to the President by the persons in charge, and annual reports shall be made to the Congress.

Sec. 7. That the governor of the Panama Canal shall, in connection with the operation of such Canal, have official control and jurisdiction over the Canal Zone and shall perform all duties in connection with the civil government of the Canal Zone, which is to be held, treated, and governed as an adjunct of such Panama Canal. Unless in this Act otherwise provided all existing laws of the Canal Zone referring to the civil governor or the civil administration of the Canal Zone shall be applicable to the governor of the Panama Canal, who shall perform all such executive and administrative duties required by existing law. The President is authorized to determine or cause to be determined what towns shall exist in the Canal Zone and subdivide and from time to time resubdivide scid Canal Zone into subdivisions, to be designated by 
name or number, so that there shall be situated one town in each subdivision, and the boundaries of each subdivision shall be clearly defined. In each town there shall be a magistrate's court with exclusive original jurisdiction coextensive with the subdivision in which it is situated of all cases in which the principal sum claimed does not exceed three hundred dollars, and all criminal cases wherein the punishment that may be imposed shall not exceed a fine of one hundred dollars or imprisonment not exceeding thirty days or both, and all violations of police regulations and ordinances and all actions involving possession or title to personal property or the forcible entry and detainer of real estate. Such magistrates shall also hold preliminary investigations in charges of felony and offenses under section ten of this Act, and commit or bail in bailable cases to the district court. A sufficient number of magistrates and constables, who must be citizens of the United States, to conduct the business of such courts shall be appointed by the governor of the Panama Canal for terms of four years and until their successors are appointed and qualified, and the compensation of such persons shall be fixed by the President, or by his authority, until such time as Congress may by law regulate the same. The rules governing said courts and prescribing the duties of said magistrates and constables, oaths, and bonds, the times and places of holding such courts, the disposition of fines, costs, forfeitures, enforcements of judgments, providing for appeals therefrom to the district court, and the disposition, treatment, and pardon of convicts shall be established by order of the President. The governor of the Panama Canal shall appoint all notaries public, prescribe their powers and duties, their official seal, and the fees to be charged and collected by them.

Sec. 8. That there shall be in the Canal Zone one district court with two divisions, one including Balboa and theother including Cristobal; and one district judge of the said district, who shall hold his court in both divisions at such time as he may designate by order, at least once a month in each division. The rules of practice in such district court shall be prescribed or amended by order of the President. The said district court shall have original jurisdiction of all felony cases, of offenses arising under section ten of this Act, all causes in equity, admiralty, and all cases at law involving principal sums exceeding three hundred dollars and all appeals from judgments rendered in magistrates' courts. The 
jurisdiction in admiralty herein conferred upon the district judge and the district court shall be the same that is exercised by the United States district judges and the United States district courts, and the procedure and practice shall also be the same. The district court or the judge thereof shall also have jurisdiction of all other matters and proceedings not herein provided for which are now within the jurisdiction of the Supreme Court of the Canal Zone, of the Circuit Court of the Canal Zone, the District Court of the Canal Zone, or the judges thereof. Said judge shall provide for the selection, summoning, serving and compensation of jurors from among the citizens of the United States, to be subject to jury duly in either division of such district, and a jury shall be had in any criminal case or civil case at law originating in said court on the demand of either party. There shall be a district attorney and a marshal for said district. It shall be the duty of the district attorney to conduct all business, civil and criminal, for the Government, and to advise the governor of the Panama Canal on all legal questions touching the operation of the Canal and the administration of civil affairs. It shall be the duty of the marshal to execute all process of the court, preserve order therein and do all things incident to the office of marshal. The district judge, the district attorney, and the marshal shall be appointed by the President, by and with the advice and consent of the Senate, for terms of four years each, and until their successors are appointed and qualified, and during their terms of office shall reside within the Canal Zone, and shall hold no other office, nor serve on any official board or commission, not receive any emoluments except their salaries. The district judge shall receive the same salary paid the district judges of the United States, and shall appoint the clerk of said court, and may appoint one assistant when necessary, who shall receive salaries to be fixed by the President. The district judge shall be entitled to six weeks' leave of absence each year with pay. During his absence, or during any period of disability or disqualification from sickness or otherwise to discharge his duties, the same shall be temporarily performed by any circuit or district judge of the United States who may be designated by the President, and who, during such service, shall receive the additional mileage and per diem allowed by law to district judges of the United States when holding court away from their homes. The district attorney and the marshal shall be paid each a salary or five thousand dollars per annum. 
Sec. 9. That the records of the existing courts and all causes, proceedings, and criminal prosecutions pending therein as shown by the dockets thereof, except as herein otherwise provided, shall immediately upon the organization of the courts created by this Act be transferred to such new courts having jurisdiction of like cases, be entered upon the dockets thereof, and proceed as if they had originally been brought therein, whereupon all the existing courts, except the Supreme Court of the Canal Zone, shall cease to exist. The President may continue the Supreme Court of the Canal Zone and retain the judges thereof in office for such time as to him may seem necessary to determine finally any causes and proceedings which may be pending therein. All laws of the Canal Zone imposing duties upon the clerks or ministerial officers of existing courts shall apply and impose such duties upon the clerks and ministerial officers of the new courts created by this Act having jurisdiction of like cases, matters, and duties.

All existing laws in the Canal Zone governing practice and procedure in existing courts shall be applicable and adapted to the practice and procedure in the new courts.

The Circuit Court of Appeals of the Fifth Circuit of the United States shall have jurisdiction to review, revise, modify reverse, or affirm the final judgments and decrees of the District Court of the Canal Zone and to render such judgments as in the opinion of the said appellate court should have been rendered by the trial court in all actions and proceedings in which the Constitution, or any statute, treaty, title, right, or privilege of the United States, is involved and a right thereunder denied, and in cases in which the value in controversy exceeds one thousand dollars, to be ascertained by the oath of either party, or by other competent evidence, and also in criminal causes wherein the offense charge is punishable as a felony. And such appellate jurisdiction, subject to the right of review by or appeal to the Supreme Court of the United States as in other cases au thorized by law, may be exercised by said circuit court of appeals in the same manner, under the same regulations, and by the same procedure as nearly as practicable as is done in reviewing the final judgments and decrees of the district courts of the United States.

Sec. 10. That after the Panama Canal shall have been completed and opened for operation the governor of the Panam a Canal shall have the right to make such rules and regulations, subject to the approval of the President, touching the 
right of any person to remain upon or pass over any part of the Canal Zone as may be necessary. Any person violating any of such rules or regulations shall be guilty of a misdemeanor, and on conviction in the District Court of the Canal Zone shall be punished by a fine not exceeding five hundred dollars or by imprisonment not exceeding a year, or both, in the discretion of the court. It shall be unlawful for any person, by any means or in any way, to injure or obstruct, or attempt to injure or obstruct, any part of the Panama Canal or the locks thereof or the approaches thereto. Any person violating this provision shall be guilty of a felony, and on conviction in the District Court of the Canal Zone shall be punished by a fine not exceeding ten thousand dollars or by imprisonment not exceeding twenty years, or both, in the discretion of the court. If the act shall cause the death of any person within a year and a day thereafter, the person so convicted shall be guilty of murder and shall be punished accordingly.

Sec. 11. That section five of the Act to regulate commerce, approved February fourth, eighteen hundred and eightyseven, as heretofore amended, is hereby amended by adding thereto a new paragraph at the end thereof, as follows:

"From and after the first day of July, nineteen hundred and fourteen, it shall be unlawful for any railroad company or other common carrier subject to the Act to regulate commerce to own, lease, operate, control, or have any interest whatsoever (by stock ownership or otherwise, either directly, indirectly, through any holding company, or by stockholders or directors in common, or in any other manner) in any common carrier by water operated through the Panama Canal or elsewhere with which said railroad or other carrier aforesaid does or may compete for traffic, or any vessel carrying freight or passengers upon said water route or elsewhere with which said railroad or other carrier aforesaid does or may compete for traffic; and in case of the violation of this provision each day in which such violation continues shall be deemed a separate offense."

Jurisdiction is hereby conferred on the Interstate Commerce Commission to determine questions of fact as to the competition or possibility of competition, af ter full hearing, on the application of any railroad company or other carrier. Such application may be filed for the purpose of determining whether any existing service is in violation of this section and pray for an order permitting the continuance of any ves- 
sel or vessels already in operation, or for the purpose of asking an order to install new service not in conflict with the provisions of this paragraph. The commission may on its own motion or the application of any shipper institute proceedings to inquire into the operation of any veesel in use by any railroad or other carrier which has not applied to the commission and had the question of competition or the possibility of competition determined as herein provided. In all such cases the order of said commission shall be final. If the Interstate Commerce Commission shall be of the opinion that any such existing specified service by water other than through the Panama Canal is being operated in the interest of the public and is of advantage to the convenience and commerce of the people and that such extension will neither exclude, prevent, nor reduce competition on the route by water under consideration, the Interstate Commerce Commission may, by order, extend the time during which such service by water may continue to beoperated beyond July first, nineteen hundred and fourteen. In every case of such extension the rates, schedules, and practices of such water carrier shall be filed with the In terstate Commerce Commission and shall be subject to the Act to regulate commerce and all amendments thereto in the same manner and to the same extent as is the railroad or other common carrier controlling such water carrier or interested in any manner in its operation: Provided, Any application for extension under the terms of this provision filed with the Interstate Commerce Commission prior to July first, nineteen hundred and fourteen, but for any reason not heard and disposed of before said date may be considered and granted thereafter.

No vessel permitted to engage in the coastwise or foreign trade of the United States shall be permitted to enter or pass through said Canal if such ship is owned, chartered, operated, or controlled by any person or company which is doing business in violation of the provisions of the Act of Congress approved July second, eighteen hundred and ninety, entitled, "An Act to protect trade and commerce against unlawful restraints and monopolies," or the provisions of sections seventy-three to seventy-seven, both inclusive, of an Act approved August twenty-seventh, eighteen hundred and ninety-four entitled, "An Act to reduce taxation, to provide revenue for the Government, and for other purposes," or the provisions of any other Act of Congress amending or supplementing the said Act of July second, eighteen hundred and 
ninety, commonly known as the Sherman Antitrust Act, and amendments thereto, or said sections, of the Act of August twenty-seventh, eighteen hundred and ninety-four. The question of fact may be determined by the judgment of any court of the United States of competent jurisdiction in any cause pending before it to which the owners or operators of such ship are parties. Suit may be brought by any shipper or by the Attorney General of the United States.

That section six of said Act to regulate commerce, as heretofore amended, is hereby amended by adding a new paragraph at the end thereof, as follows:

"When property may be or is transported from point to point in the United States by rail and water through the Panama Canal or otherwise, the transportation being by a common carrier or carriers, and not entirely within the limits of a single State, the Interstate Commerce Commission shall have jurisdiction of such transportation and of the carriers, both by rail and by water, which may or do engage in the same, in the following particulars, in addition to the jurisdiction given by the Act to regulatecommerce, as amended June eighteenth, nineteen hundred and ten:

"(a) To establish physical connection between the lines of the rail carrier and the dock of the water carrier by directing the rail carrier to make suitable connection between its line and a track or tracks which have been constructed from the dock to the limits of its right of way, or by directing either or both the rail and water carrier, individually or in connection with 'one another, to construct and connect with the lines of the rail carrier a spur track or tracks to the dock. This provision shall only apply where such connection is reasonably practicable, can be made with safety to the public, and where the amount of business to be handled is sufficient to justify the outlay.

"The commission shall have full authority to determine the terms and conditions upon which these connecting tracks, when constructed, shall be operated, and it may, either in the construction or the operation of such tracks, determine what sum shall be paid to or by either carrier. The provisions of this paragraph shall extend to cases where the dock is owned by other parties than the carrier involved.

"(b) To establish through routes and maximum joint rates between and over such rail and water lines, and to determine all the terms and conditions under which such lines shall be operated in the handling of the traffic embraced. 
"(c) To establish maximum proportional rates by rail to and from the ports to which the traffic is brought, or from which the traffic is brought, or from which it is taken by the water carrier, and to determine to what traffic and in connection with what vessels and upon what terms and conditions such rates shall apply. By proportional rates are meant those which differ from the corresponding local rates to and from the port and which apply only to traffic which has been brought to the port or is carried from the port by a common carrier by water.

(d) If any rail carrier subject to the Act to regulate commerce enters into arrangements with any water carrier operating from a port in the United States to a foreign country, through the Panama Canal or otherwise, for the handling of through business between interior points of the United States and such foreign country, the Interstate Commerce Commission may require such railway to enter into similar arrangements with any or all other lines of steamships operating from said port to the same foreign country."

The orders of the Interstate Commerce Commission relating to this section shall only be made upon formal complaint or in proceedings instituted by the commission of its own motion and after full hearing. The orders provided for in the two amendments to the Act to regulate commerce enacted in this section shall be served in the same manner and enforced by the same penalties and proceedings as are the orders of the commission made under the provisions of section fifteen of the Act to regulate commerce, as amended June eighteenth, nineteen hundred and ten, and they may be conditioned for the payment of any sum or the giving of security for the payment of any sum or the discharge of any obligation which may be required by the terms of said order.

Sec. 12. That all laws and treaties relating to the extradition of persons accused of crime in force in the United States to the extent thay they may not be in conflict with or superseded by any special treaty entered into between the United States and the Republic of Panama with respect to the Canal Zone, and all laws relating to the rendition of fugitives from justice as between the several States and Territories of the United States, shall extend to and be considered in force in the Canal Zone, and for such purposes and such purposes only the Canal Zone shall be considered and treated as an organized Territory of the United States. 
Sec. 13. That in time of war in which the United States shall be engaged, or when, in the opinion of the President, war is imminent, such officer of the Army as the President may deșignate shall, upon the order of the President, assume and have exclusive authority and jurisdiction over the operation of the Panama Canal and all of its adjuncts, appendants, and appurtenances, including the entire control and government of the Canal Zone, and during a continuance of such condition the governor of the Panama Canal shall, in all respects and particulars as to the operation of such Panama Canal, and all duties, matters, and transactions affecting the Canal Zone, be subject to the order and direction of such officer of the Army.

Sec. 14. That this Act shall be known as, and referred to as, the Panama Canal Act, and the right to alter, amend, or repeal any or all of its provisions or to extend, modify, or annul any rule or regulation made under its authority is expressly reserved.

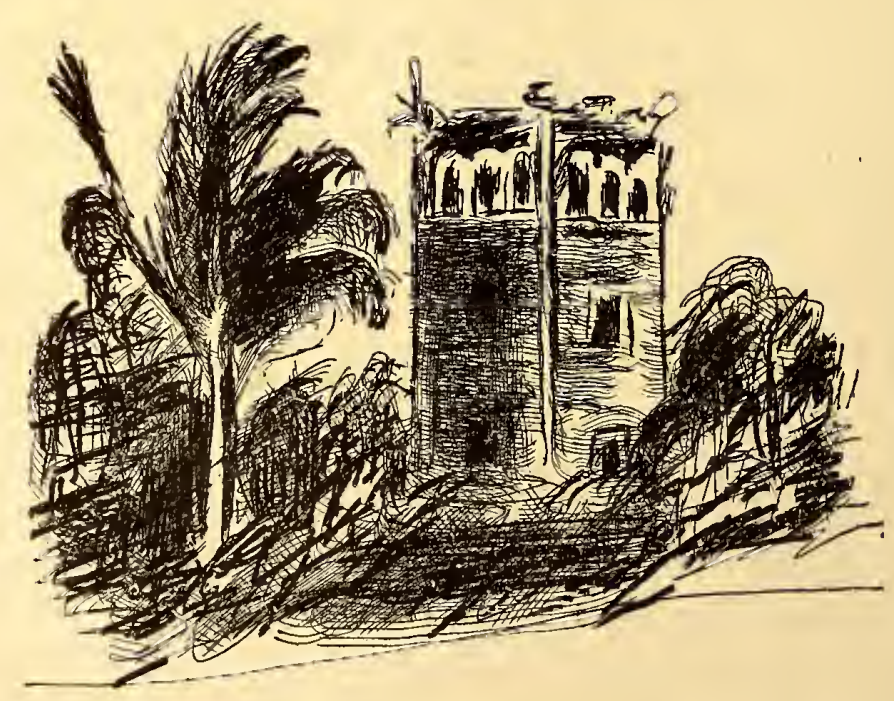

TOWER OF CHURCH OF ST. ANASTATIUS-Old Panama. 


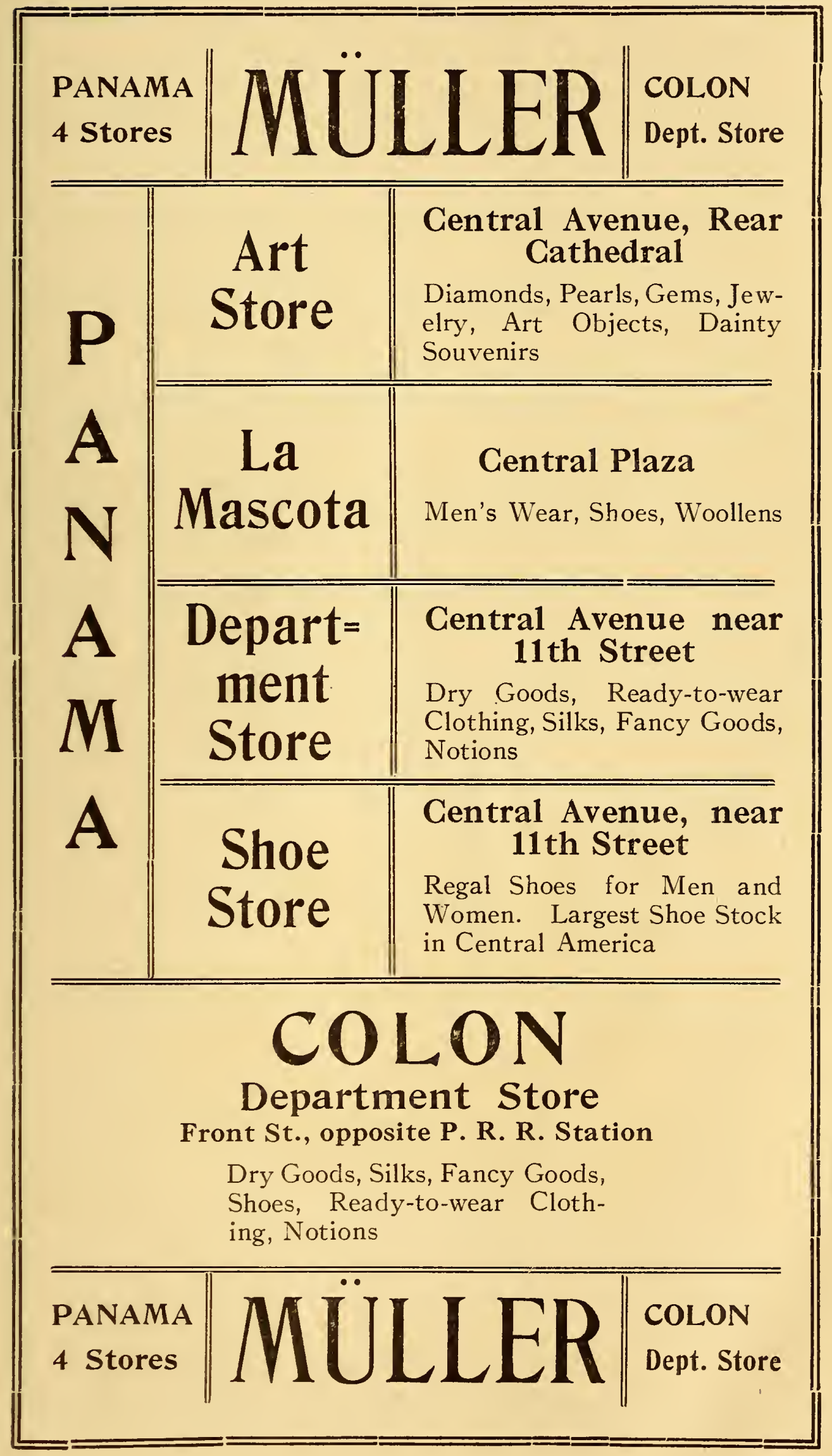


MISCELLANEOUS INFORMATION.

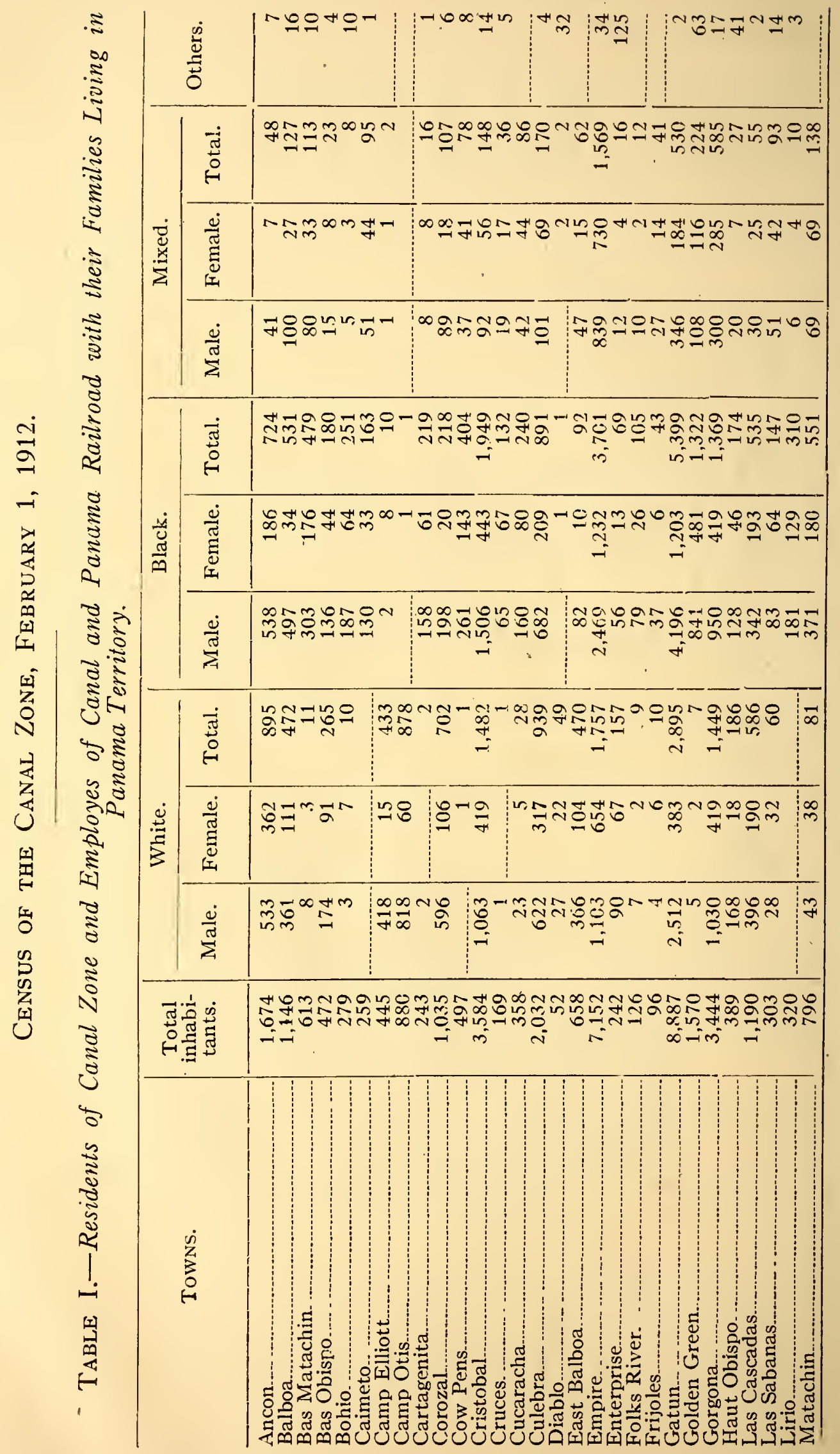


MISCELLANEOUS INFORMATION.

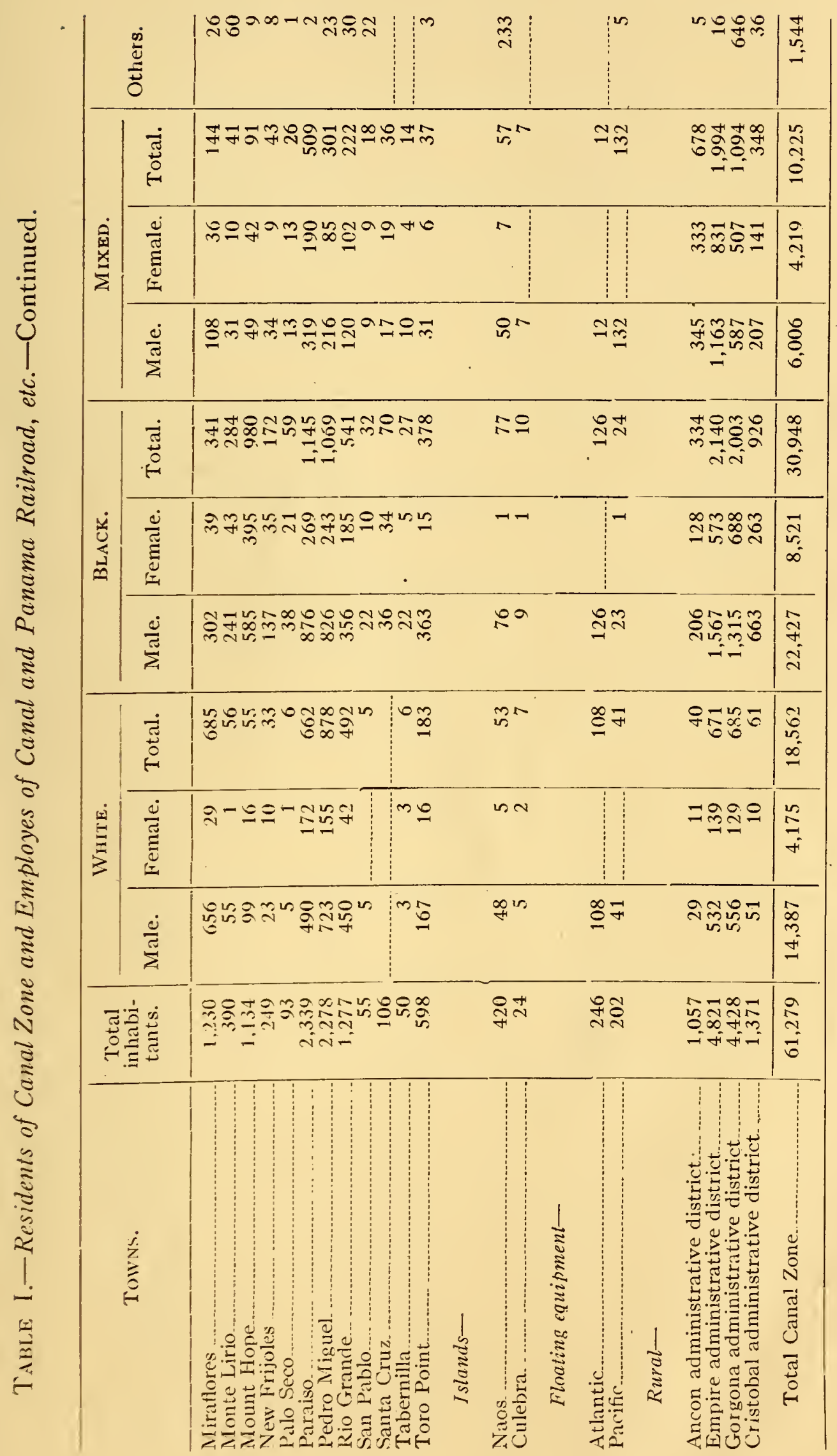




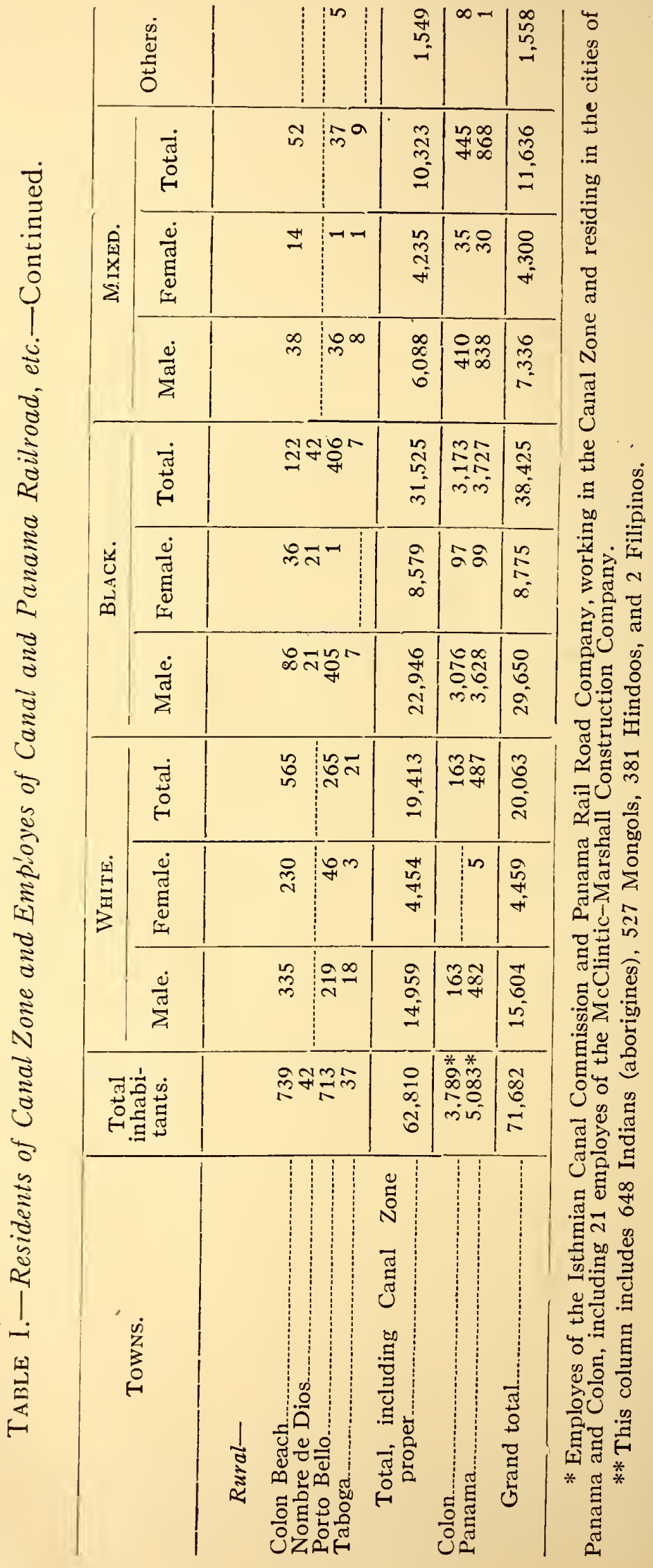


TABLE II.-Total Population of the Canal Zone Classified by Country of which Citizen or Suhjecl, and Sex.

\begin{tabular}{|c|c|c|c|}
\hline \multirow[b]{2}{*}{ Country. } & \multicolumn{3}{|c|}{ Aggregate. } \\
\hline & Male. & Female. & Total. \\
\hline Argentina................ & 7 & 2 & \\
\hline Austria-Hungary .... & 36 & 2 & 38 \\
\hline Belgium & 4 & & \\
\hline Bolivia.......................... & 9 & 5 & 14 \\
\hline 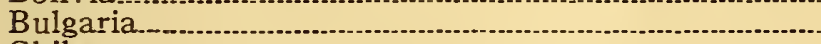 & 1 & & 1 \\
\hline Chile & 27 & 5 & 32 \\
\hline China & 471 & 45 & 516 \\
\hline Colombia & 967 & 554 & 1,521 \\
\hline Costa Rica...... & 53 & 24 & 77 \\
\hline Cuba & 51 & 21 & 72 \\
\hline Denmark.......... & 35 & 21 & 56 \\
\hline Ecuador.................. & 39 & 4 & 43 \\
\hline 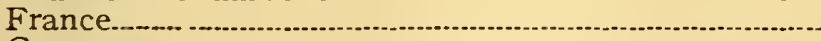 & 2,263 & 497 & 2,760 \\
\hline Germany & 61 & 14 & 75 \\
\hline Great Britain......... & 22,396 & 8,466 & 30,859 \\
\hline Greece & 1,285 & & 1,291 \\
\hline 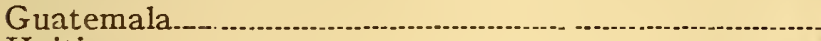 & 3 & 4 & 7 \\
\hline . & 68 & 6 & 74 \\
\hline 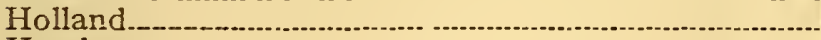 & 35 & 4 & 39 \\
\hline 20-1 & 5 & 1 & 6 \\
\hline 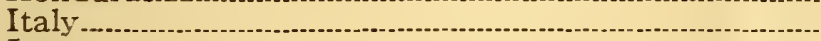 & 800 & 12 & 812 \\
\hline Japan & 4 & 1 & 5 \\
\hline Liberia & 1 & & \\
\hline Mexico. & 67 & 5 & .72 \\
\hline 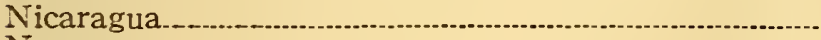 & 53 & 20 & 73 \\
\hline - & 23 & 2 & 25 \\
\hline (1) & 2,903 & $3,73 \overline{3}$ & 7,636 \\
\hline Paraguay & 2 & & 3 \\
\hline Peru & $20 \overline{8}$ & 15 & 223 \\
\hline Portugal & 113 & 6 & 119 \\
\hline 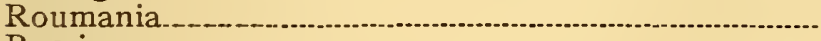 & 1 & & \\
\hline Russia & 48 & & 54 \\
\hline Salvador-1. & 9 & 2 & 11 \\
\hline 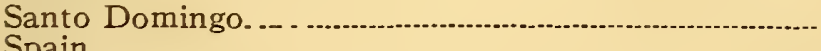 & & & \\
\hline $\begin{array}{l}\text { Spain } \\
\text { Sweden }\end{array}$ & $\begin{array}{r}3,809 \\
20\end{array}$ & 496 & $\begin{array}{r}4,305 \\
24\end{array}$ \\
\hline Switzerland & 13 & & $\begin{array}{l}24 \\
14\end{array}$ \\
\hline (n) & 36 & 6 & 42 \\
\hline United States............ & 8,199 & 3,651 & $11,8.50$ \\
\hline ( & 39 & & 44 \\
\hline Tota! & 45,163 & 17,647 & 62,810 \\
\hline
\end{tabular}





\section{Index.}

\begin{tabular}{|c|c|}
\hline & \\
\hline bandonment of Trade Route 119 & $\begin{array}{l}\text { Boggs, F. C.... } \\
\text { Bohio................. }\end{array}$ \\
\hline 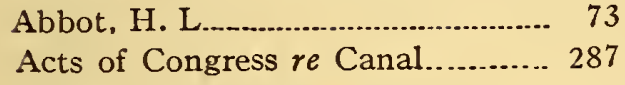 & Bolivar, canal project.................... 60 \\
\hline dministration, Canal._._............. 69 & 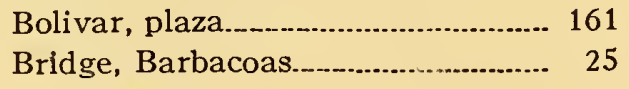 \\
\hline $\begin{array}{l}\text { See also Government } \\
\text { gramonte, A }\end{array}$ & \\
\hline gramonte, A & Empire.. \\
\hline $\begin{array}{l}\text { horca Lagarto. } \\
\text { Albert Edwards", book by, quo- }\end{array}$ & $\begin{array}{l}\text { Gamboa } \\
\text { Monte Lirio }\end{array}$ \\
\hline & Brodley, Joseph.............................. 200 \\
\hline an Canal, history.................. & Bryan, Henry \\
\hline ........... 48 & Buccaneers.....................22, 115, 184 \\
\hline ers.......46, 48 & 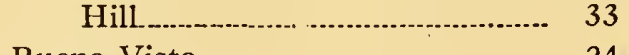 \\
\hline ............... 174 & Buena Vista. \\
\hline 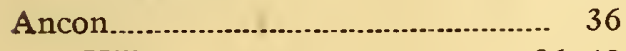 & $\mathrm{hn} \ldots \ldots \ldots \ldots$ \\
\hline 36,40 & 1. \\
\hline 211 & \\
\hline & 58 \\
\hline '...............- 2 & 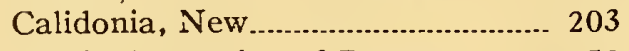 \\
\hline …-...................... 199 & on of Panama...-...... 153 \\
\hline 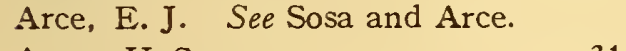 & $\ldots-\ldots-\ldots$ \\
\hline ...........-... 31 & 30 \\
\hline-1 & 31 \\
\hline -......................... & $-57,109$ \\
\hline$\ldots . .75,76,95$ & \\
\hline 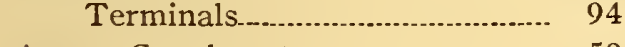 & 109 \\
\hline 58 & \\
\hline$\ldots-\ldots 6,205$ & ........ 301 \\
\hline$-25,207$ & ....... 65 \\
\hline & r.....-.-.-. 88,92 \\
\hline -......... 106 & ............... 65 \\
\hline ......... 143 & 114 \\
\hline ....... 143 & ... 147 \\
\hline$\ldots \ldots$ & .. 91 \\
\hline & \\
\hline ................... 92 & -155 \\
\hline ................. 29 & \\
\hline -............. 105 & Census, \\
\hline 112 & -136 \\
\hline$\ldots . .135,145$ & 207 \\
\hline$-a^{-1}$ & Chagres River......22, 74, 87, 108, 197 \\
\hline $7,65,71$ & Chagres village. See Fort San Lorenzo. \\
\hline & \\
\hline & \\
\hline & \\
\hline
\end{tabular}


Page.

Childs, O. W

Chinese, storekeepers.

See also Population.

Chiriqui Prison.

Christ Church, Colon

Churches and church work $10,44,46$,

49,141

Churches of Panama

164

Church separated from State

105

Cimarrones

$.111,112$

Citrus fruits

146

Classes and races in Panama..121, 136,

137,301

Clayton-Bulwer treaty .........60, 97, 243

Clothing and food.

92

Clubhouses, Canal

44,53

Clubs, Union

163

University

162

Coach tariff, Colon.

16

Panama.

174

Coconuts

144

Cocos Island treasure.

149

Coffee

145

Cold

223

Colon, History

Fires.

, 127

Hospital

10

Threat of Massacre, 1903

Columbus

$7,14,106$

Knights of

45,54

Comber, W. Gr

$.42,71$

Commissaries

44,92

Commissions, Isthmian Canal, Per-

sonnel.

69,71

Concessions, Canal.. $60,61,69$ Railroad

61,101

Concrete

81,91

\section{See also Locks}

Congress of Panama. 123

Consulting Engineers of 1906

Contraband trade.

118

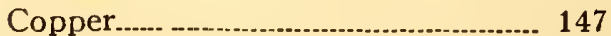

Corozal__........................................ 36

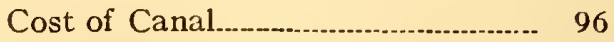

Council of the Indies............ 113

Courts, Canal Zone.......................39, 72

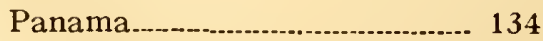

Cranes, Locomotive....................... 92

See also Locks, Pedro Miguel, Miraflores.

Cristobal
Cruces......................................... 203

Page.

Culebra__........................................ 32

Culebra Cut....29, 31, 62, 76, 87, 88, 219

Slides......................................... 32

Villages........................................ 29

Culebra Penitentiary........................ 53

Customs regulations........................... 227

Dams_.............................19, 83, 84, 85

Darien..._............................................. 205 See also Indians.

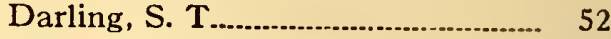

Dates in history of Panama........... 105

Davis, Geo. W.......................69, 73, 207

Deeks, W. E................................... 52

Devol, C. A....................................... 94

Dingler, Jules..._................................ 41

La Folie...........................................

Distances by Panama.................... 97

Docks, Atlantic Terminal _...__......15, 94 Pacific_........................................... 95

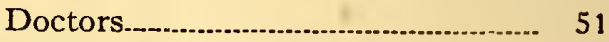

See also Hospitals.

Drainage of Culebra Cut.......... 90

Drake, E. A...............................72, 101

Francis................................. 116

Dredges......................................... 90, 92

Drills__.............................................. 92

Dry Docks........................................ 96

Dynamite explosion..................... 29

Earthquakes

$-127,225$

Eating, Canal Workers.............45, 69, 92

Education-See Schools.

Edwards, Albert. See "Albert Edwards.'

Empire

Endicott, M. T......................... 70

Equipment and Supplies................90, 92

Ernst, O. H._._._._................................... 70

Espinoza_....................................... 107

Esquemeling, quoted..183, 184, 195, 200

Estimated cost of canal................... 96

Ethnic divisions in Panama 121, 137, 301

European laborers._._._...........47, 54, 301

Expenditures for canal...................... 96

Explosion, Bas Obispo._-..-.-.-_-_-..- 29

Fabrega, Jose de

Feuille, Frank.................................. 72

Financial resources of Panama........ 133

Findlay, Carlos................................. 65

Fires in city...................................... 151

Flat arch church.................................. 171

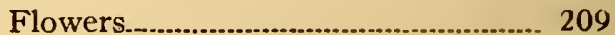




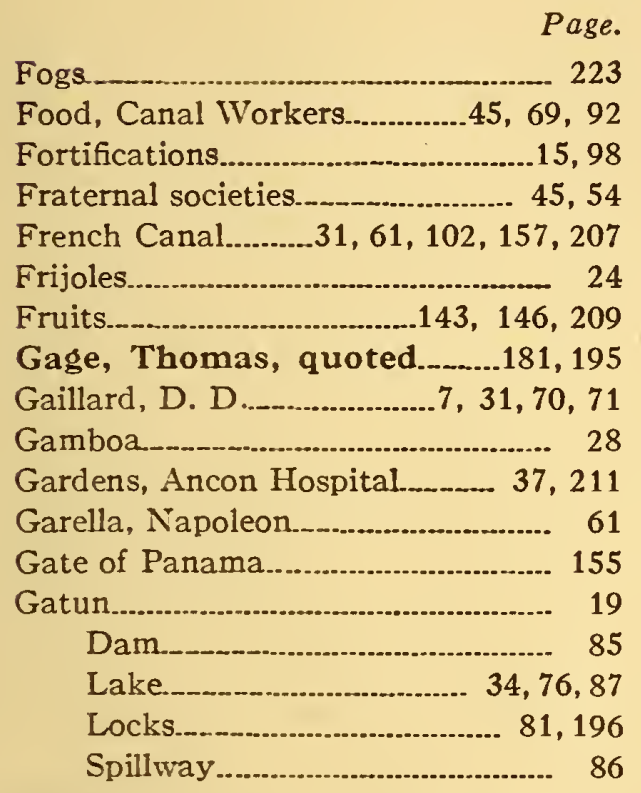

Gilbert, J. K

Goethals, Geo. IV 6, 7, 49, 70, 71, 73, 101

Gold._............................................... 147

Indian Ornaments of............... 140

Gorgas, W. C.____...........7, 65, 67, 70, 72

Gorgona, Shops..................................... 25

Village._........................................ 25

Government, Canal Zone....69, 243, 287

Colombian ................123, 126, 127

Colonial.................................... 120

Old Panama.................................. 113

Republic......................................... 133

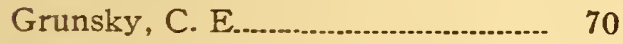

Gudger, H. A._............................ 72

Guerard, A.................................... 73

Haines, P. C.

Harrod, B. M............................. 70

Hay-Herran Treaty............................ 129

Hay-Paunceforte Treaty.............98, 253

Headquarters, New Canal_............... 42

Health statistics................................. 67

Heat..........................................-... 219

Hecker, F. J._.

Hodges, H. F...............................7, 71

Hospitals_..__......... 10,37, 51, 64, 155

Hotels, Canal.................................. 45, 92 Colon_.._................................. 9, 11

Panama_.................. 152, 158, 163

Housing._._................................... 68

Hunter, W. H .............................. 73

Independence from Colombia 129 From Spain.............................. 121

Indians..........................110,112, 138, 205

Ornaments and Pottery........... 140

Page

Injured and sick.............................. 51

International Board of Consulting

Engineers.......................................... 73

Ivory Nuts._....................................... 145

James, Wm. McC..................... 52

Jesuit church ruins............................. 172

Jungle hamlets.................................. 23

Kangaroos _................................ 45, 54

Kinghills, William............................... 193

Laborers.....................47, 54, 68, 143, 301 See also Negroes.

Labor Unions._............................... 54

Lake, Gatun_............................... 22 87

Miraflores.................................... 87

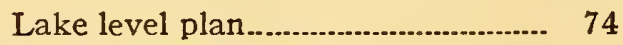

Lake villages, description..._......... 21

Land titles.............................................. 143

Las Bovedas..................................... 161

Las Casas...-.....................................-...-. 110

Las Cascadas........................................ 30

Latitude............................................. 225

Laws.......................................... 287

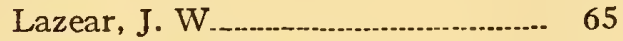

Lesseps, Ferdinand de.................. 61, 62 Charles, residence....................... 14

Plaza de...................................... 153

Library......................................... 158, 162

Lighting of city............................ 152

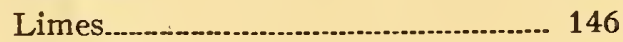

Lion Hill............................................ 23

Lloyd, J. A....................................... 61

Lock Canal plan................................. 74

Locks, General._._._..................... 74,78 Gatun_................................... 19,81

Miraflores.................................... 84

Pedro Miguel................................. 82

Locomotives.............................. 30, 35, 93

Longitude........................................... 225

Lottery.............................................. 160

Loveridge, S. M..._.................... 51

Lumber................................................. 146

MacGregor, Gregory................... 193

Mahogany............................................ 146

Magoon, C. E............................... 70

Malaria__.......................................... 62, 65

Manzanillo Island. See Colon.

Map of Canal Routes..........-........... 59

Canal Zone._.............................. 2

Colon in 1912........................ 17

Panama city, 1857..................... 150

Panama city, 1912................... 177 


\begin{tabular}{|c|c|}
\hline \multirow{2}{*}{$\begin{array}{rr}\text { Page. } \\
\end{array} \quad 182$} & \multirow{2}{*}{ Page. } \\
\hline & \\
\hline Porto Bello in 1736 & $\begin{array}{l}\text { Otis, Handbook by. } \\
\text { Otoque, Island. }\end{array}$ \\
\hline rina hotel & $\begin{array}{l}\text { Otoque, Island... } \\
\text { Oxenham, John. }\end{array}$ \\
\hline arines, U. 'S & \\
\hline arine shops & Pacific Ocean Discovery .........105, 106 \\
\hline 15 & Entrance to Canal...........77, 95 \\
\hline 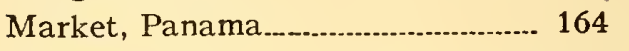 & Panama, Canal_a. 57, 109 \\
\hline$F$ & 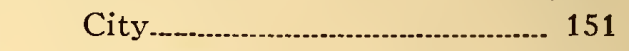 \\
\hline $13,45,54$ & Congress._._._. 123 \\
\hline f $1856 \ldots \ldots \ldots \ldots$ & 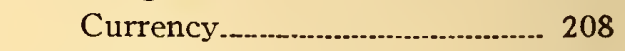 \\
\hline 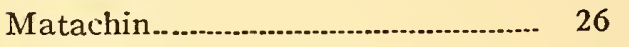 & 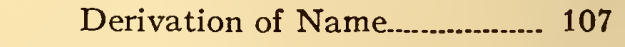 \\
\hline and Supplies...................... & Panama, History ...... \\
\hline $\mathrm{H}$ & Old._. \\
\hline C. A. 71 & Presidents ............................. \\
\hline 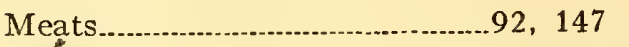 & 7, 101 \\
\hline $16,25,93$ & ........ 133 \\
\hline 241 & .... 259 \\
\hline 51,64 & Panama Patchwork, book \\
\hline & 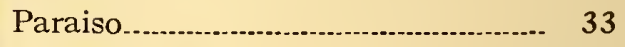 \\
\hline 60 & 117 \\
\hline ........ 92 & ... 70,73 \\
\hline 219 & ..... 74 \\
\hline & \\
\hline ................. & 2,207 \\
\hline & .................. 148 \\
\hline Locks....... & 148,205 \\
\hline 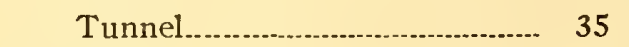 & \\
\hline ............................ 18 & 106 \\
\hline 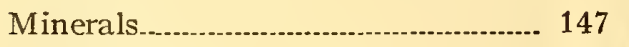 & - 34 \\
\hline & \\
\hline 28 & s.........- \\
\hline$\ldots 117,184,193,199$ & ystem, Canal Zone._............ \\
\hline $37,64,65$ & \\
\hline 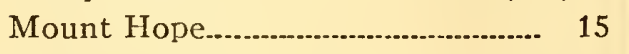 & 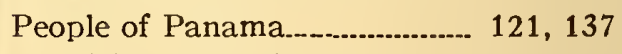 \\
\hline $66,152,207$ & Zone................ 51 \\
\hline & tals. \\
\hline ational Institute................. 173 & Pile drive \\
\hline tion............... 19,22 & rs \\
\hline $10,47,50,55$ & Pizarro, Francisco-_on \\
\hline & \\
\hline 98 & Plaza Bolivar \\
\hline 46.173 & 156,159 \\
\hline & \\
\hline of $1848 \ldots \ldots . . . . .61$ & Railway \\
\hline & Santa Ana \\
\hline a Canal.... & Political status of Panama.... 133, 259 \\
\hline . & Population, Canal Zone \\
\hline ed._. $\quad 73$ & 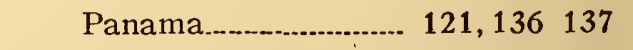 \\
\hline Dios_..__._._..... 81, 108, 202 & Panama City \\
\hline & Boo \\
\hline & \\
\hline & Postage.... \\
\hline
\end{tabular}




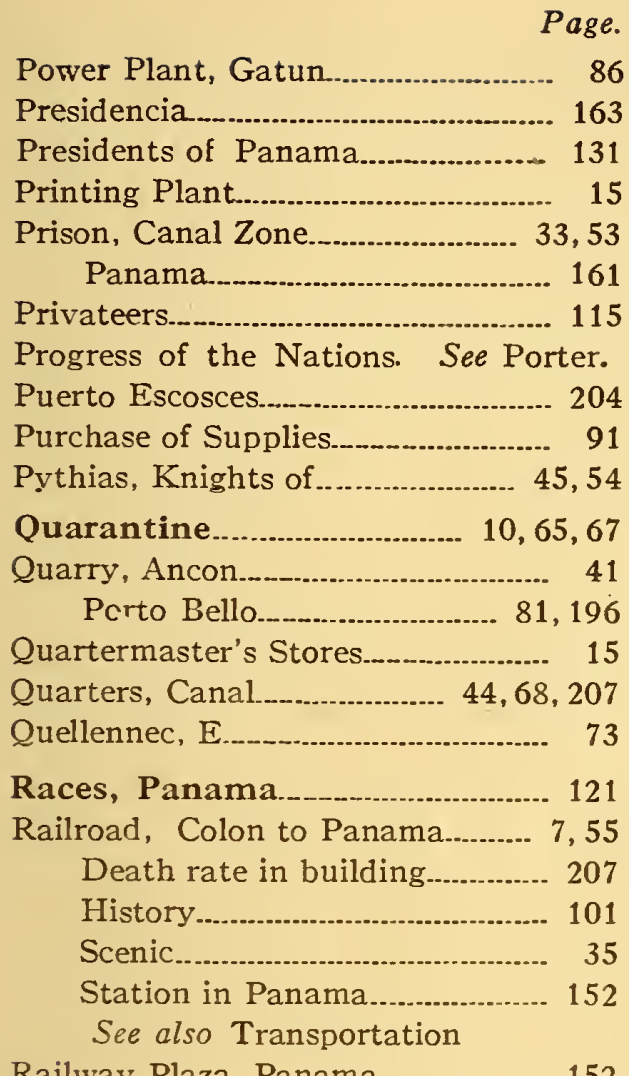

Railway Plaza, Panama._-_.............. 152

Rains................................................... 221

Randolph, I................................ 73

Red Men

Reed, Walter.................................... 65

Relocation country.....................-...-. 28

Repair facilities on Canal................ 95

Resources of Panama_._....................- 143

Restricted District in Panama........ 155

Revolution, Causes........................... 125

Series._._........................................ 123

Spanish-American...................... 121

1885

1889-1902

$1903 \ldots$

Rio Grande, discovery..................... 108

Ripley, J......................................... 73

River route._._.................................... 108

Roads, Macadamizing..................... 66

Robinson, A. L.......................... 72

Rock breaker, subaqueous............... 92

Rock for concrete............ 41, 81, 84, 196

Roosevelt, Theodore............. 69, 73, 241

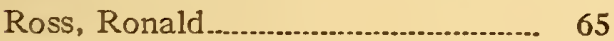

Rousseau, H. H........................ 7, 70, 71

Rubber................................................ 145

Salvation Army .......................... 51

San Blas, Canal Route..................... 58

Indians_..................................... 138
Sanitation and Health

See also Hospitals.

San Lorenzo, Fort_.......................... 197

Santa Maria del Antigua_............... 106

San Miguel Bay................................. 106

San Pablo............................................. 25

Schools, Canal Zone.......................... 52

Panama...................... 105, 140,173

Scotch colony..................................... 203

Screening, House................................. 66

Sea Gate of Panama.......................... 163

Sealevel channels.................................. 76

Sealevel or lock plan........................ 73

Seasons................................................... 221

Sea Wall, Panama._.............................. 161

Seville, Casa de Contratacion.......... 114

Serviss, G. P., book............................ 233

Sewers and health.............................. 66

Sewers in city................................. 152

Shon!s, T. P

Shops.......................................... 16, 25, 96

Shoppers Guide, Colon._............... 16

Panama......................................... 176

Sibert, W. L............................ 19, 70, 71

Sick and Injured............................... 51

Silver money, Panama....................... 209

Slavery, Abolition...-.................. 105, 110

Slides in Culebra Cut_._................ 32,90

Sloth_............................................. 207

Smith, H. A. A._._.......................... 72

Smith, J. A..._........................ 72, 101

Smith, Jackson.................................. $\quad 70$

Social life of Canal........................... 44

Social conditions, Canal................... 48

Sosa and Arce......2, 105, 107, 119, 181

Spanish laborers. See Laborers.

Spillway Dams, Construction......... 87

Spillways ….......................-...-........ 86

Sports_.............................................. 46

Spreaders................................................ 92

Siars......................................... .............. 233

Steamshovels.................................... 88, 92

Stearns, F. P................................. 73

Stephens, J. L.,.............. 7, 10, 58, 101

Stevens, J. F_.................... 32, 58, 70, 73

Storehouses..._.................................. 15

Strangers Club................................... 13

Sugar.................................................. 145

Supplies and Stores.................. 15, 90, 95

Surveys of cana! routes.............. 58, 109

Swamp, Black................................... 27

Tabernilla.................................. 25

Taboga......... 52, 107, 111, 122, 149, 189 


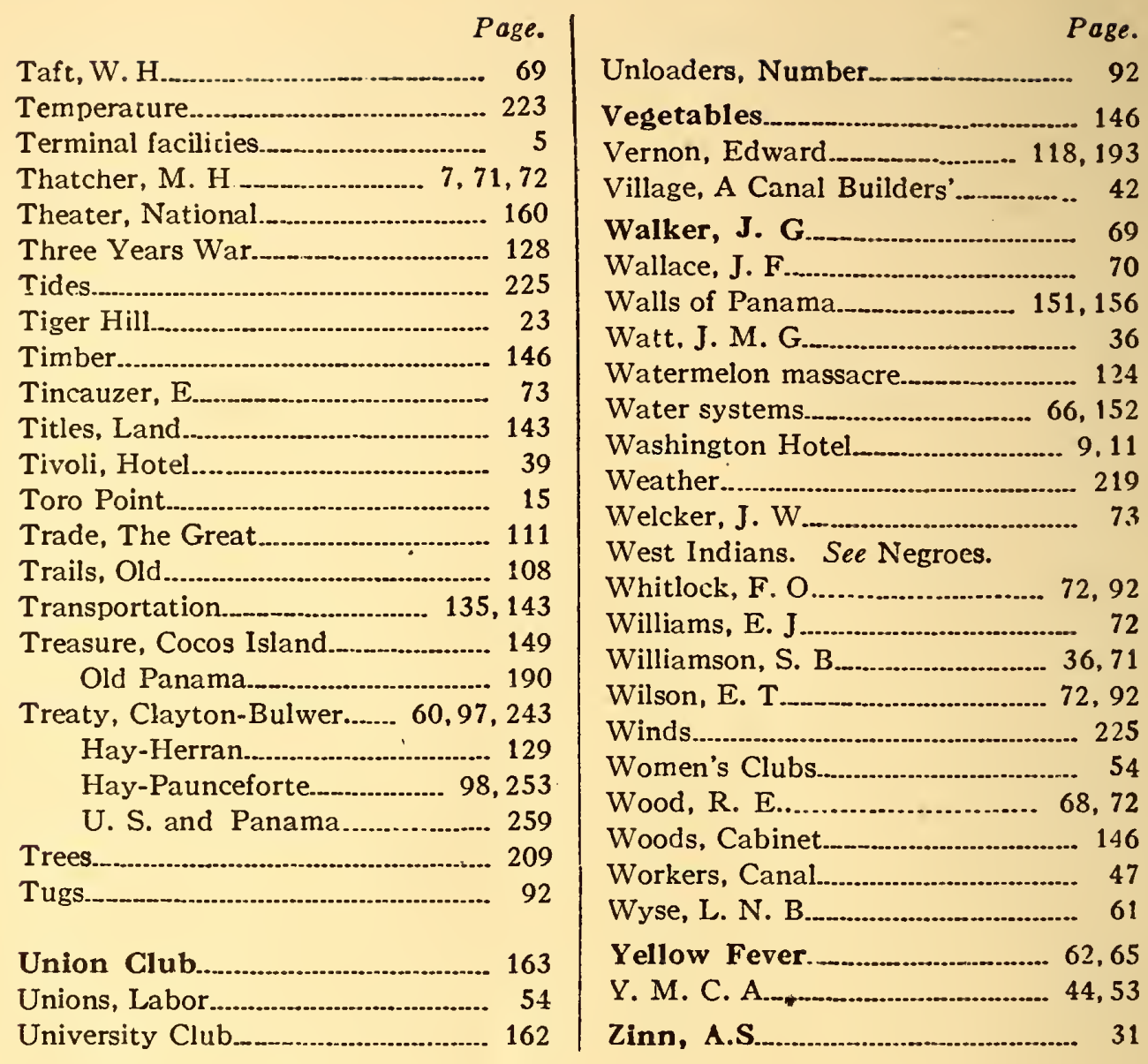






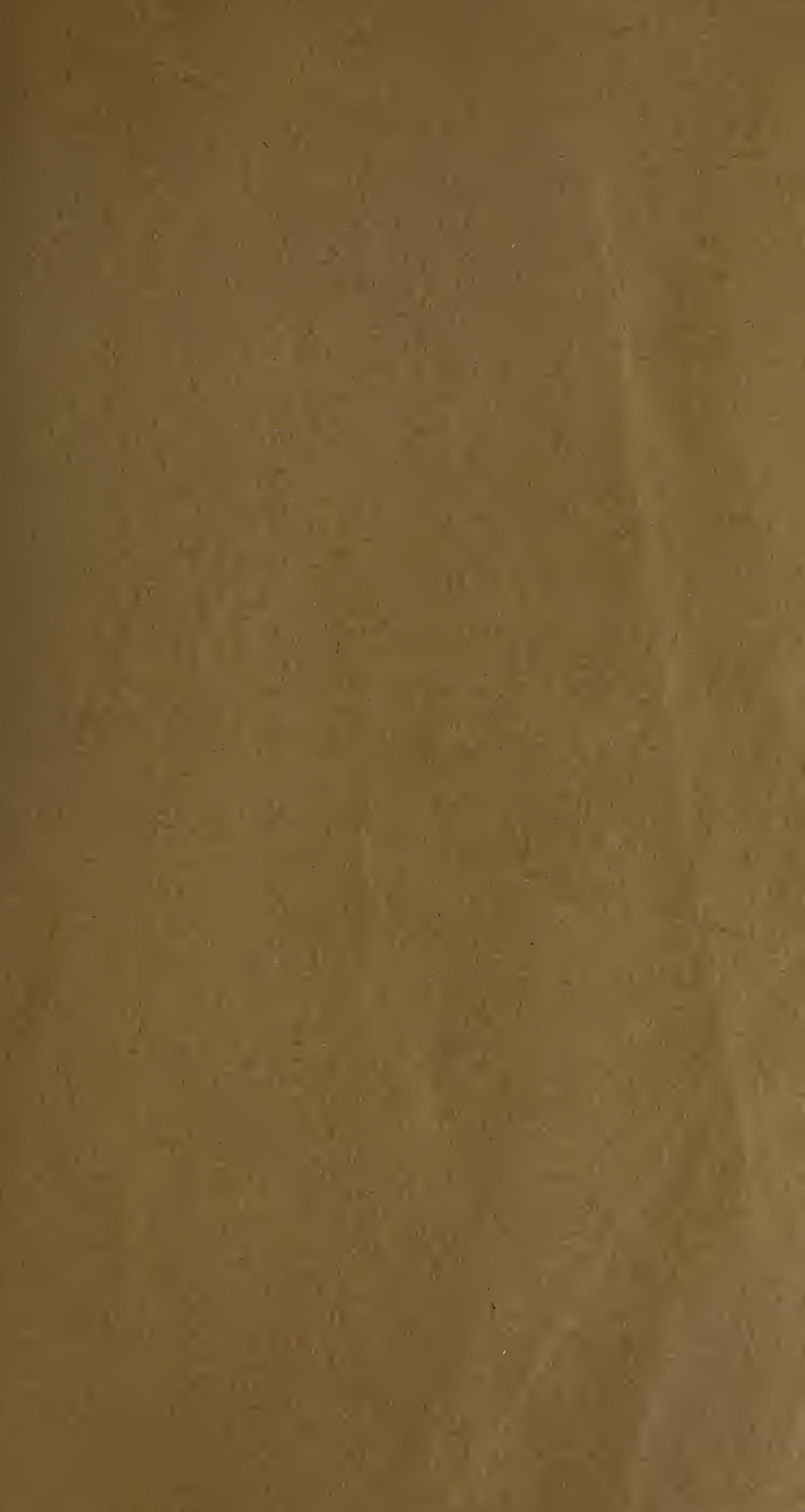




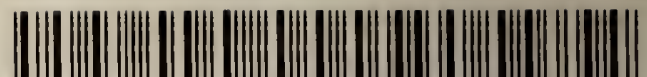

